\title{
CORRUPTION IN HIGHER EDUCATION
}

\author{
By \\ Ararat L. Osipian \\ Dissertation \\ Submitted to the Faculty of the \\ Graduate School of Vanderbilt University \\ in partial fulfillment of the requirements \\ for the degree of \\ DOCTOR OF PHILOSOPHY \\ in \\ Leadership and Policy Studies
}

May, 2013

Nashville, Tennessee

Approved:

Professor Robert L. Crowson

Professor Stephen P. Heyneman

Professor M. Donald Hancock

Professor William R. Doyle 


\section{TABLE OF CONTENTS}

Page

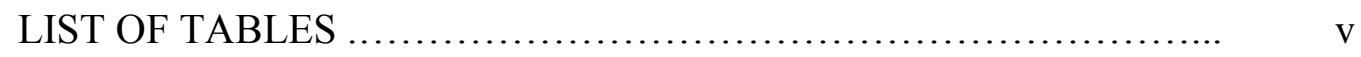

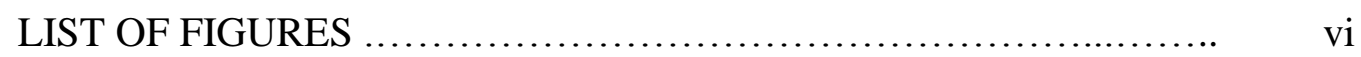

Chapter

I. INTRODUCTION ...........................................

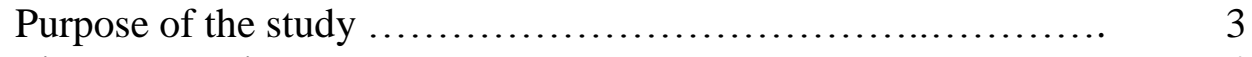

Literature review ......................................... 4

Conceptual framework ...................................... 19

Informative base of the study ................................ 29

Research methodology ..................................... 29

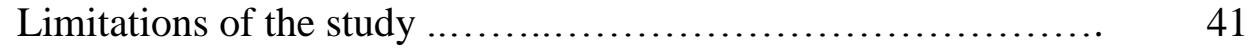

II. HIGHER EDUCATION CORRUPTION IN THE WORLD MEDIA: PREVALENCE, PATTERNS, AND FORMS ................... 43

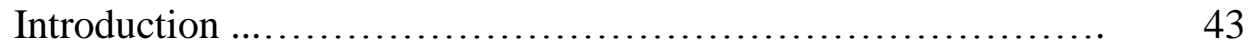

Research question ....................................... 44

Research methodology ...................................... 46



Comparing the findings by country ........................ 62

Conclusion .............................................. 77

III. GREY AREAS IN HIGHER EDUCATION:

ILLEGALITY VERSUS CORRUPTION ...................... 79

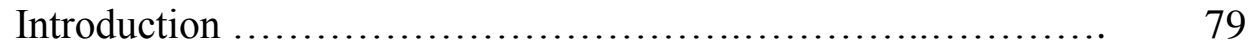

Legality versus corruptibility $\ldots \ldots \ldots \ldots \ldots \ldots \ldots \ldots \ldots \ldots \ldots \ldots . . . \ldots$

Corruption as a grey area ................................. 87

Selection criteria for legal cases ........................... 90

Legal cases: description and essence ......................... 93

Analysis and discussion: legal cases in the context .............. 99

Legal argumentation ........................................ 104

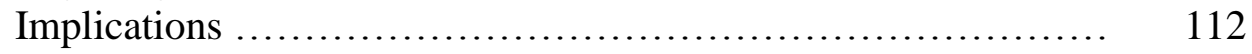

Conclusion .............................................. 116

IV. CORRUPTION HIERARCHIES IN HIGHER EDUCATION ...... 119 
Introduction .............................................. 119

Corruption in hierarchies .................................. 120

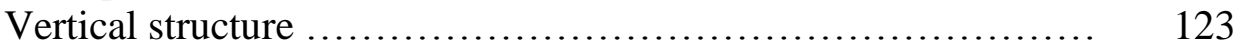

Transition from vertical structure to horizontal structure .......... 126

Horizontal structure ......................................... 130

Transition from horizontal structure to vertical hierarchy ........... 133

Vertical hierarchy ........................................ 134

Conclusion ............................................. 145

V. CORRUPTION IN HIGHER EDUCAITON

AS A TOOL OF ADMINISTRATIVE CONTROL ................. 149

Introduction ................................................. 149

Concept of corruption and coercion ......................... 151

Principal-Agent frame .................................... 157

Economic rationale for the vertical structure of control.......... 160

Model of compliance and control ............................. 164

Horizontal structure of control ............................... 167

Genesis of state-university relations ......................... 172

Vertical structure of control ................................. 176

Horizontal structure of control in universities .................. 182

State-university relations ................................... 184

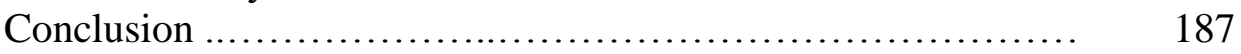

VI. MODELING EDUCATORS' MISCONDUCT

WITH CELLULAR AUTOMATA................................. 191

Introduction ............................................ 191

The problem of misconduct in education ..................... 192

Theoretical framework ...................................... 193

Methodology .............................................. 195

Model of corrupt behavior .................................. 196

Model simulation .......................................... 199

Results and interpretation ................................. 205

Conclusion ............................................... 215

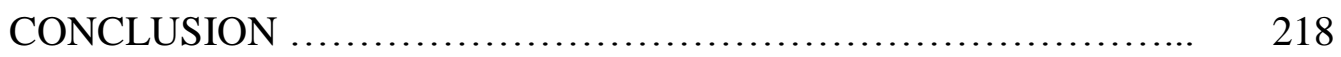

Appendix

A. NOTICE OF INTENTION TO SUE (LETTER) ............. 226

B. EVERYDAY CORRUPTION PRACTICE IN THE RUSSIAN 229

FEDERATION

C. RESULTS OF CELLULAR AUTOMATON ................ 236

REFERENCES ................................................. 243 


\section{LIST OF TABLES}

Table

1. Corruption in higher education: classification, forms, and

approaches

2. Criteria used and classification of corruption in higher education.....48

3. Cases on the grounds of the False Claims Act, Consumer Protection Act, Higher Education Act, and Anti-Trust Laws after 2000

4. Structural forms of organization of corruption and their major characteristics in higher education...

5. A numerical example of defining the educational employee's decision of whether to support the system, based on such considerations, as total benefit, costs, and social pressure, (period $t-1$ ).

6. A numerical example of defining the educational employee's decision of whether to support the system, based on such considerations, as total benefit, costs, and social pressure, (period $t)$.

7. A numerical example of defining the educational employee's decision of whether to support the system, based on such considerations, as total benefit, costs, and social pressure, (period $t+1)$ 


\section{LIST OF FIGURES}

Figure

Page

1. Dynamics of The Chronicle of Higher Education reports on corruption in higher education by phenomenon, 1998-2007. .73

2. Dynamics of Gazeta.ru reports on corruption in higher education

by phenomenon, 1998-2007

3. Dynamics of Newsru reports on corruption in higher education by phenomenon, 1998-2007.

4. Dynamics of The Times Higher Education Supplement reports on corruption in higher education by phenomenon, 1998-2007.

5. Dynamics of media reports on corruption in higher education

by locus, 1998-2007.

6. Vertical structure of organization with corruption

7. Parallel structure in a corrupt organization with the vertical structure...127

8. Horizontal structure with the parallel attachment.

9. Pyramid-like structure of the vertical hierarchy

10. High-density pyramidal structure of the vertical hierarchy.

11. Evolution and possible options in corrupt organizational structures...143

12. Horizontal structure in administrative control with corrupt behavior...172

13. Horizontal structure of administrative control in the university with corrupt behavior

14. Function 1. Cellular automaton for 1000 educators in a 365-day period, with corrupt educators being distributed randomly in day one...207

15. Function 1. Randomly selected magnified textural structure. .208

16. Function 1. Cellular automaton for 1000 educators in a 365-day period, with one corrupt educator initially in day one... .208 
17. Function 1. Randomly selected magnified textural structure

18. Function 2. Cellular automaton for 1000 educators in a 365-day period, with corrupt educators being distributed randomly in day one....210

19. Function 2. Randomly selected magnified textural structure...........210

20. Function 2. Cellular automaton for 1000 educators in a 365-day period, with one corrupt educator initially in day one...................211

21. Function 2. Randomly selected magnified textural structure..........211

22. Function 3. Cellular automaton for 1000 educators in a 365-day period, with corrupt educators being distributed randomly in day one...212

23. Function 3. Randomly selected magnified textural structure..........213

24. Function 3. Cellular automaton for 1000 educators in a 365-day period, with one corrupt educator initially in day one ....................213

25. Function 3. Randomly selected magnified textural structure..........214 


\section{CHAPTER I}

\section{INTRODUCTION}

Corruption in higher education is a newly emerging topic in the field of education research. Some aspects of corruption in education have been addressed in recent works by Anderson (1989, 1992, 1999), Eckstein (1993, 2001, 2003), Heyneman (2004, 2007), Noah and Eckstein (2001), Petrov and Temple (2004), Segal (2004), Sykes (1988), and Washburn (2005), as well as in numerous news publications. Scholarly work on corruption in higher education is lacking while the problem itself is significant.

Legal cases on corruption in higher education grow in number and receive more attention from the media, legislators, numerous constituents, and from the general public. The presence of corruption in higher education throughout the world is a growing concern for the industry as it influences its effectiveness and efficiency. The negative impact of higher-education corruption on economic development and social cohesion is also disturbing.

Corruption increases inequalities in access to higher education, slows down the process of accumulation of human capital, and hence impedes economic growth and negatively affects economic development and social progress. The negative effects of corruption on economic growth and personal income were investigated in the works of Leff (1964), Huntington (1968), Myrdal (1968), Bates (1981), Wade (1982) Lui (1985, 1986, 1999), De Soto (1989), Klitgaard (1986, 1988, 1991), Murphy, Shleifer and Vishny 
(1991, 1993), Mauro (1995, 1997, 1998), Choi and Thum (1998), Gong (2003), Svensson (2003, 2005), Reinikka and Svensson (2004, 2005), and Heyneman, Anderson and Nuraliyeva (2008). With the rapid internationalization of higher education and the growing volume of trade in educational services, matters of educational credentials--and credibility in general--become ever more important.

The three major issues in higher education are access, quality, and equity. These issues are universal and at stake in every nation. Corruption affects all three of these issues. It has a negative impact on the quality of higher education and other services; it increases inequality in access to higher education, and causes inequities. Every nation solves problems of access, quality, and equity differently. Thus, also corruption in higher education is part of the news in every country, the ways in which the national media reflects on corruption in higher education differ. The same is true for legal actions, undertaken in order to prosecute and curb corruption.

Factors that reshape higher education in the former Soviet Union (FSU) are common to all countries. These are a growing demand for higher education, globalization, and government inefficiency. Countries of the former Soviet Bloc reform higher education faster than most European countries. Political, economic, ideological, language, and cultural factors are all important for the reform. One of the negative sides of the reform is growing corruption of higher education institutions and in the educational industry overall. Corruption, and higher education corruption in particular, is something known but not described theoretically. At the same time, increasing scale and scope of corruption in higher education urges better understanding of the problem within the context of socio-economic transformations. 


\section{Purpose of the study}

The purpose of this study may be defined as follows: setting a conceptual ground for further methodological developments and empirical research focused on different aspects of corruption in higher education and the development of measurements and indicators of its prevalence in higher education. Major research question may be formulated as follows: what is corruption in higher education, what is known about its prevalence, and how it can be approached?

The set of questions derived from the major question is as follows:

- What is corruption in higher education as a socio-economic category?

- What are the methods to study corruption in higher education?

- How is corruption in higher education defined and approached in the media and in legal cases in countries with different educational systems?

- What are the forms of corruption in higher education? or In what forms is corruption present in higher education? How does corruption in higher education manifest itself?

- What are the mechanisms through which corruption in higher education sustains itself?

Goals of this study may be formulated as follows:

- Categorization and classification of corruption in higher education, based on both media reports and legal records; 
- Identification of methods and development of approaches to study corruption in higher education;

- Description of corruption in higher education, using number of theoretical frames and analytical techniques;

- Investigation of corruption in higher education in international, and comparative perspectives;

- Identification of possible proactive and reactive policies in higher education institutions in respect to corruption;

- Identification of the problems and directions for further studies of corruption in higher education.

The work is intended to make a conceptual contribution to the subfield of corruption that exists in several disciplines, including political science and economics, and almost non-existent in the field of education, and higher education policy in particular.

\section{Literature review}

Corruption is present to a larger or lesser extent in any society at any stage of its development. Historically, fundamental changes in societies lead to a rapid and great increase in corruption along with other illegal activities. These illegal activities, however, later become legal and so what was regarded as corrupt before is regarded as something normal. Conversely, what was earlier accepted as the norm and well-tolerated by a society may well become an unacceptable practice of corruption. In many societies or 
types of organizations, corruption is indispensable to a state of stability, or a steady state. Highly institutionalized corruption is normally present in societies where corruption is widespread and takes place on a large scale. In such cases institutionalized corruption substitutes for the legal institutions or complements them.

During fundamental economic and social transformations, the phenomenal growth of corruption does not necessarily lead to its institutionalization. Even widespread corruption may long stay un-institutionalized. Such a long-term chaotic condition may be explained in part by the contrary forces exerted or preventive measures undertaken by the government or groups in civil society. Consistent with expectations, historical aspect of corruption may be found to be as important as the structural basis of corruption. Genesis of the university and its corrupt practices are described in works of Baldwin and Goldthwaite (1972), Brockliss, Denley, and Schmitt (1981), Compayre (1893), Flynn (1988), Haskins (1957), Hill (1972), Hyde (1972), Kaminsky (1972), Kibre (1948), Maieru (1993), Payne (1975), Piltz (1981), Rait (1931), Rashdall (1936), Thelin (1982), Verger (1972, 2000), and others.

In non-democratic societies corruption, informally approved, imposed, or regulated by public authorities, is an indicator of a vertical power rather than an indicator of a weak state (Andreski, 1966, 1968; Darden, 2001, 2002). Corruption is used on a systematic basis as a mechanism of direct and indirect administrative control and redistribution of wealth on the state level and all the way down to local authorities and administrations of public and private institutions. Control and redistribution of wealth, in this case, are based on blackmail and selective justice. 
According to the data analysis, presented by Shleifer and Treisman (2003, pp. 27 28), administrative corruption is very high in poor countries of the former Soviet Union, such as Uzbekistan, Armenia, and Azerbaijan, lower in the Russian Federation, Bulgaria, and Lithuania, and even lower in relatively wealthy Hungary and Slovenia. Individuals' perceptions about corruption put Russia lower than Argentina, Brazil, Romania, or Lithuania. Svensson (2005) notes that, "All of the countries with the highest levels of corruption are developing or transition countries. Strikingly, many are governed, or have recently been governed, by socialist governments." (Svensson, 2005, p. 24) Referring to the works of Lipset (1960), Demsetz (1967), and Glaeser, La Porta, Lopez-de-Silanes and Schleifer (2004), the author points out that higher per capita income and higher level of human capital reduce corruption.

The increasing gap between pay rates in private and public sectors of the economy urges public employees to seek other sources of income (Gorodnichenko and Sabirianova, 2006). Along with the health services industry, higher education has become one of the industries, most affected by corruption. At the same time rapid development of higher education, its partial privatization and increasing flow of financial resources have created a base for corruption. College professors, who lost the bulk of their savings to inflation in early 1990s, and are now grossly underpaid, and they adjust their professional ethics and behavior accordingly by accepting bribes and numerous other benefits and utilizing their privileged position and control over the access to higher education.

The problem of corruption in the former Soviet Bloc is reflected in a number of research papers and its existence is proven on the basis of surveys. For instance, a poll developed by the Ukrainian Institute for Social Research showed that 78 percent of 
respondents believed that all or most of the government officials have accepted bribes. More than 80 percent stated that corruption was prevalent within the judicial branch of government, while 71 percent responded in the affirmative to a query about whether they believed that most government officials were tied to the mafia or private family business relations. Moreover, good portion of Ukrainians is inclined to accept bribery as a normal part of everyday life (Woronowycz, 2003).

Solomon and Foglesong (2000, p. 75) note that the number of reported incidents in Ukraine rose two-and-a-half-fold between 1990 and 1998 to 2,449, and these incidents led to 1,641 convictions. Numerous surveys in the Russian Federation reveal the same situation with corruption. The total estimate of the amount entrepreneurs have paid to officials in 2001 approximated $\$ 33.5$ billion, slightly less than the total revenue of the Federal budget in this year (Popov, 2005, p. 33). This does not include bribes that consumers pay for access to healthcare services, social services, and educational services as well as ordinary bribes to traffic police etc. paid on a daily basis. More than half of all Russians had to pay a bribe at least once in their lives, while 19 percent do it quite often. Most often bribes are paid for medical services (51 percent of the respondents), followed by traffic violations (31 percent of the respondents) and educational services ( 20 percent of the respondents) (Newsru, June 2006).

In 1999 James Leach, Chairman of the US House Banking Committee, wrote that he had conducted a study of the most corrupt regimes, including the Philippines under Marcos, Zaire under Mabutu, and Indonesia under Suharto. Bad as these were, each was outdone by the "pervasiveness of politically tolerated corruption' in post-communist Russia (Leach, 1999; Shleifer and Treisman, 2003, p. 27). The surveys by Transparency 
International and by the World Bank picture Russia as a very corrupt country (UN, 2003). In the 2001 survey by the World Bank, Russia was $142^{\text {nd }}$ out of 160 countries. According to the Corruption Perceptions Index (CPI), Russia was $71^{\text {st }}$ out of 102. In 2006, Russia was in $121^{\text {st }}$ place with the score of 2.5 , and in 2012 it was in $133^{\text {rd }}$ place with the score of 2.8 (Transparency International, 2006, 2012). Contrary to expectations, development of a substantial private sector in higher education leads to an increase in corruption. Private higher education institutions are as corrupt as their public counterparts, which prove that not only public officials are susceptible to corruption. Moreover, perceptions of the public about corruption lead to an increase in the number of incidences of corruption and total volume of graft (Cabelkova and Hanousek, 2004; Tumennasan, 2005; Olken, 2006). An increase in public perception of corruption in higher education facilitates a further increase in corruption as well as the total amount of graft accumulated by the college instructors and administration.

Corruption is not limited to developing and transition economies only. The developed nations suffer of corruption as well. The survey conducted by the Transparency International in 2006 placed the US at $20^{\text {th }}$ position with the corruption score of only 7.3 out of 10 possible, where 10 would mean no corruption at all and 1 would mean highest level of corruption. The US shared $20^{\text {th }}$ position with Chile and Belgium, falling down from $17^{\text {th }}$ place with the score of 7.6 in 2005. Major European Union members were not much better in this regard, with France at $16^{\text {th }}$ place and Germany at $18^{\text {th }}$ place. Japan occupied $17^{\text {th }}$ position with the score of 7.6 . The recent survey conducted by the Transparency International and presented in November of 2012 places the US at $19^{\text {th }}$ position with the same corruption score of 7.3. The US borders in its 
corruption rank with Chile (20) and Uruguay (20). Major European Union members are not better in this regard, with France at $22^{\text {nd }}$ place. Germany occupies $13^{\text {th }}$ place, while the UK and Japan share $17^{\text {th }}$ position with the score of 7.4 (Transparency International, 2005, 2006, 2012).

In North America and Western Europe, concerns about large-scale corruption run high despite a low level of direct experience of bribery for services. In spite of the lack of daily experience with bribe-paying, 85 percent of respondents in North America think that the business environment is affected to a moderate or large extent by corruption while 89 percent believe that the same is true for political life (Transparency International, 2006). Media sources and legal reports point to a significant level of corruption in higher education in the developed world, ranging from the mafia ties with universities in Italy and widespread cheating on the standardized tests in the UK to bribery in entry examinations in Japan and major cases of embezzlement and financial aid fraud in the US.

Corruption is studied by scholars in few disciplines. Major approaches used by economists and political scientists in investigating and modeling corruption include principal-agent theory, game theory, red tape theory, and grease-the-wheels theory. Principal-agent theory, first developed in economics to study relations between the owners of the enterprises and their managers, is now widely used in investigating numerous issues in public policy and may be applied to the issues of higher education corruption. Principal-agent problem in the fields of public policy and economics is described by Banfield (1975), Becker and Stigler (1974), Darden (2002), Kunicova and Rose-Ackerman (2001), Rose-Ackerman (1975, 1978, 1999), and Solnick (1998), to name a few. 
Referring to Klitgaard (1988, p. 23) Gong (2002, p. 88) states that corruption: “occurs when an agent betrays the principal's interests in pursuit of his/her own or when the client corrupts the agent "if he or she (client) perceives that the likely net benefits from doing so outweigh the likely net costs" According to the "grease-the-wheels" concept of corruption, it helps overcome bureaucratic obstacles that remain from the previous regime.

Addressing the question whether higher wages for bureaucrats reduce corruption, Svensson (2005, pp. 32-33) notes that it might be true, but there is not enough evidence to support it. This statement can only be proven empirically. The evidence is very contradictory. Theories of higher wages generally do not hold. There are too many speculations around the suggestion of rising wages in order to reduce corruption. Patterns of consumption (Tumennasan, 2005), as well as perceptions about corruptness of different institutions (Cabelkova and Hanousek, 2004; Olken, 2006) influence willingness to bribe, acceptance of bribes, and considering bribery as an extra source of income.

Goorha (2002) suggests that better paid public officials are less corrupt. The red tape theory, presented by Rose-Ackerman $(1978,1999)$ and developed mathematically by Guriev (2003) may be used in explaining or justifying different measurements of corruption in higher education. Illegal income, derived from imposing the red tape, is based on monopolization of certain rights and privileges, and, more importantly discretion to allow or deny access to higher education.

Anechiarico and Jacobs (1996, p. xiii) say that "Corruption is a problem and corruption control a constant challenge for all governments. Corruption undermines 
citizens' confidence in and commitment to the commonwealth and can even destroy the legitimacy of the political system. Therefore, it is not difficult to agree with a phalanx of scholars and practitioners who argue that corruption must be controlled." Callow (1976, p. 144) concludes that "Perhaps the heart of the issue is not the kind of graft or who perpetrates it or even its magnitude but rather its impact upon the democratic process. Graft of any kind breeds distrust. Distrust breeds cynicism. Cynicism is the most powerful enemy of the democratic representative process."

In the western literature, research on corruption exists in two major areas: development economics and politics. Within development economics corruption is described as an attribute of third world countries. In politics focus is on corruption in public policy including American (Scott, 1969; Benson, 1978; Moore, 1992; Philp, 1997), Japanese (Mitchell, 1996), and Australian (Palmer, 1992) public policy. Some work is done on describing corruption in politico-economic perspective, including rent-seeking behavior (Krueger, 1974; Buchanan, et al., 1980; White, 1996), rise of the state bureaucracies (Wilson, 1975; Weber, 1978), and cross-national characteristics (Treisman, 2000).

Corruption is something difficult to define. As Keller (1978, p. 7) points out: The word "corruption" itself, as the numerous definitions attached to it in the Oxford English Dictionary attest, is an elusive and ambiguous one. For some it is a strongly normative concept, describing an illegal or immoral transgression of prevailing mores for the benefit of oneself or one's group. In this sense the presence of corruption usually is as much dependent upon the stance of the observer as it is on the act of the transgressor: I am reality- 
oriented; you are self-interested; he is corrupt. Often the corrupt do not regard themselves as such; and rightly so, by their own frame of values. Often enough (as in tyrannies) the most corrupt act is to accord with law and custom; to violate or subvert authority may well be the higher morality. Nor is corruption, even when accepted as such, necessarily harmful. No less than reform, as Samuel Hantington observed, it "may... be functional to the maintenance of a political system. Corruption has been understood in yet another sense: as something natural, organic, an ineluctable part of the business of living."

The definition of corruption varies depending on the inquiring discipline. Economics has advanced significantly in modeling corruption, but is experiencing difficulties in testing the models (Rose-Ackerman, 1978; Tirole, 1992; Bardhan, 1997). Whatever problem economists might have in explaining corruption is indicated by RoseAckerman's (1978, p. 2) definition of corruption as an "allocative mechanism" for scarce resources: "When this allocation is somehow shared between a market system in which wide inequalities in income are taken for granted, and a democratic political system that grants a formal equality to each citizen's vote... Political decisions that are made on the basis of majority preferences may be undermined by wide use of an illegal market as the method for allocation... Corrupt incentives are the nearly inevitable consequence of all government attempts to control market forces - even the "minimal" state." She recognizes that personal values limit the applicability of this approach, since economics cannot substitute for the personal integrity of political actors. State officials' profiteering is based on abuse of their discretionary powers and monopolistic positions. Johnston 
(1982, p. 4) says that not all behavior that breaks rules is corruption. "Corruption involves abuse of a public role or trust for the sake of some private benefit." Private benefit is a very broad term and may be understood differently depending on the context.

Peters and Welch (1978, p. 976) analyze corrupt acts by the component elements involved in the corrupt act and exchange: "We believe this process can meaningfully be partitioned into the "public official" involved, the actual "favor" provided by the public official, the "payoff" gained by the public official, and the "donor" of the payoff and/or "recipient" of the "favor" act." Johnston (1986, p. 379) summarizes the definitional problem: "We should not expect to find a sharp distinction between corruption and no corrupt actions. Instead, we will find fine gradations of judgment, reflecting a variety of equivocations, mitigating circumstances, and attributed motives.” Berg, Hahn, and Schmidhauser (1976, p. 3) state that the definition of corruption requires systemic concept. They write that: "Political corruption violates and undermines the norms of the system of public order which is deemed indispensable for the maintenance of political democracy."

Lasswell and Rogow (1963, p. 320) propose that "A corrupt act violates responsibility toward at least one system of public or civic order and is in fact incompatible with (destructive of) any such system. A system of public or civic order exalts common interest over special interest; violations of the common interest for special advantage are corrupt." For Leon (1993, p. 25): "Political corruption is a cooperative form of unsanctioned, usually condemned policy influence for some type of significant personal gain, in which the currency could be economic, social, political, or ideological remuneration", and concludes that political corruption is an integrated, systemic part of 
the American political process. The same suggestion could probably be made for the system of higher education in the former Soviet Union (FSU).

Key (1934, p. 386) considers corruption in politics and public policy in the US and defines graft “... as an abuse of power for personal or party profit.” Key (1934, pp. 386-387) says that graft usually involves a relationship between the official exercising the power which is abused and some other individual or individuals and that the techniques of graft are the methods employed in these relationships plus the methods used in cases of graft involving only a single individual.

In the Post-Soviet literature, corruption is normally described in the area of the shadow economy and to the lesser extent in relations between the economy and different levels of bureaucracy and administration that is in political organizations. A newer trend in Russian and Ukrainian research on corruption is to present a descriptive analysis of corruption perceptions by population based on pools and surveys. Higher education corruption is still not described theoretically. It is much more difficult to estimate the volume of corruption in higher education than to estimate the volume of a shadow or unofficial economy. The shadow economy in the FSU is mostly legal in its process and becomes illegal at the stages of different forms of realization. Products produced by the shadow economy are legal and do not differ from those produced legally, but avoiding taxation and illegal agreements make the sector a shadow economy.

One of the approaches is to consider corruption as illegal by its nature within any organization, even if it is broadly accepted and treated as normal. Corruption in Russia is deeply rooted in the culture of the society and has a proud tradition. In historical perspective Russian tsar Ivan Grozny, one of the patriarchs of the centralized Russian 
Empire, prescribed public servants to feed from the service. ${ }^{1}$ This was his laconic response to the voices of the state servicemen from provinces asking for salaries. Salaries were not paid for years and people in the state service collected their benefits from the public. Those were bribes in kind and rarely money.

As follows from the Collection of Laws of the Russian Empire, dated 1630, state servicemen were sworn not to embezzle from the state and not to accept bribes from the public (Pisar'kova, 2004). In the era of Peter the Great, material conditions of Russian bureaucrats and state clerks were good (Milov, 2001, p. 487). However, starting in 1723, they have deteriorated significantly. Small salaries did not cover even the cost of living and furthermore were never disbursed in time (Pososhkov, 1937, p. 221). The chronic budget deficit was yet another reason for state servicemen to seek additional sources of income. They worked as horsemen, grooms, and gatekeepers. In 1727 salaries for lower level state clerks were abolished altogether. The state servicemen were once again advised to "feed from the service." (Solov'ev, 1991, p. 89) The ruling regime was somewhat critical only about the direct extortion from the public, but other forms of corruption, including gifts and gratuities, were allowed (Demidova, 2002, pp. 142-145). Bribery in state offices was de facto legalized while corrupt practices led to the development of the culture of legal nihilism. Not only poorly paid state clerks were susceptible to corruption. Well-paid high-ranked bureaucrats collected much bigger bribes than did their subordinates.

A similar situation takes place in contemporary Russia and other parts of the former Russian Empire, including Ukraine and Central Asia. Salary for public workers,

\footnotetext{
${ }^{1}$ kormitsia so sluzhby.
} 
including higher education instructors and administrators is often not paid in time. Arrays in Russia and Ukraine use to reach six to twelve months and more, while in countries of the Central Asia salary in many instances is non-existent. While in Russia corruption was not wide spread during the soviet times and was not well tolerated by the public, in Central Asia corruption simply became more open and rampant than it used to be, though still would be illegal. Involvement in the illegal activities requires braking personal ethics and certain norms of behavior and establishing new type relations with the same and new people and organizations. Russian higher education, however, chose this way of adaptation to the new economic realities.

The need for strong definitions of corruption, bribe, bribery, graft, misconduct, misuse, embezzlement, etc. in the field of corruption is obvious. Definitions of corruption such as "abuse of public office for the personal gain" are too broad and lack specificity. They raise at least two questions. What is abuse and what is public office? As far as one can understand the word "abuse," its meaning is very broad. The word abuse can have numerous interpretations and contexts. One can take, for instance, child abuse and alcohol abuse. In these two cases the same word has two different meanings. More recent substitution of the word abuse by the word misuse does not change the insufficiency of the definition. The meaning of "public office" is even broader. Moreover, corruption is an abuse not only of the public office, unless "public office" is defined as everything where interests of at least two individuals meet and where they coordinate their activities.

This research asserts that the definition of corruption as the abuse of public office for private gain is convenient in a sense that it is perfectly inclusive. The strength of this definition is in its inclusiveness, but the weakness is that it is not specific. The definition 
is very general. It is applicable, but it does not discover the essence of corruption. We use a narrow definition of corruption that regards corruption as such only if it constitutes an illegal act. This approach is grounded in the very nature of the concept of corruption and coercion that anticipates blackmail on the basis of the risk of accusation and legal prosecution by the state.

A substantial body of literature is now being developed on corruption as a phenomenon of transition economies, starting from the Soviet times (Azrael, 1965) and up to the present (Holmes, 1996; Easter, 2000; Hellman, 2000; Kotkin, 2001; Kotkin and Sajo, 2002; Zhdanov, 2002). The issue of corruption within the field of economics is now also being studied in China (Gong, 1997, 2002; He, 2000). In the post-Soviet literature, corruption is normally described in the area of the shadow economy and to a lesser extent in relations between the economy and different levels of bureaucracy and the administration of political organizations. A newer trend in Russian and Ukrainian research on corruption presents a descriptive analysis of perceptions about corruption held by the population based on polls and surveys.

All of these theoretical approaches are used to address the classical issues of corruption, including first of all state-businesses relations where entrepreneurs interact with bureaucrats, and bureaucrats interact with their supervisors and their constituents. Little theory has been developed on interactions of the general public with public employees or servicemen, including health care professionals and educators. Corruption that takes place in such interactions is known as petty corruption. However, corruption in higher education is not limited to petty or everyday corruption only. Large scale embezzlement and fraud can be met in national educational systems, not only in 
development and transition economies, but in the US and European Union as well. Higher education corruption is still not described theoretically.

Quite a few works address different aspects of corruption in higher education, including relations between the university and business (Anderson, 2001; Bok, 1982; Cichy, 1990; Soley, 1995; Washburn, 2005), academic misconduct (Anderson, 1999; Arrowsmith, 1966; Bailey and Richards, 1985; Decoo, 2002), research misconduct and research fraud (bell, 1992; Bird and Dustira, 2000; Breitmayer, 2000; Brydensholt, 2000; Coggins, 2000; Culliton, 1987; Koshland, 1987; Rhoades and Gorski, 2000; StegemannBoehl, 2000), academic dishonesty and fraud (Blankenship and Whitley, 2000; Eckstein, 2003; Fairweather, 1996; McCabe, Trevino, and Butterfield, 1999; Pulvers and Diekhoff, 1999; Silber, 1970, 1980; Simon, 1971, Wilshire, 1990), bribery in admissions and academic process (Chapman, 2003; Hallak and Poisson, 2004; Johns, 2003; Miyazaki, 1981; Stetar, Panych, and Cheng, 2005; Suroor, 2005; Waite and Allen, 2003), cheating (Cizek, 1999; Croucher, 1997; Diekhoff, 1996; Greaney and Kellaghan, 1996; Kerkvliet and Sigmund, 1999; Maline and Maramark, 1993; McCabe and Trevino, 1996; Moffat, 1990; Saxe and Spalter, 1992), plagiarism (Goldsmith, 1998; Lathrop and Foss, 2000; Mallon, 1989; Roig, 1999), diploma mills (Snyder, 1974; Stewart, 1988), and intercollegiate athletics (Delany, 1997; Duderstadt, 2000; Friday and Hesburgh, 1993; Sperber, 1990, 2000).

The literature is overwhelmed with considerations of scientific misconduct, cheating, and plagiarism, while investigations into such aspects of corruption as bribery and embezzlement are lacking. Also, the literature on corruption in higher education is 
focused on academia itself and does not account for the socio-economic context and settings in which academic corruption develops.

\section{Conceptual framework}

Corruption in higher education is something understood and acknowledged but not necessarily described in theoretical terms. Most information on corruption comes in the form of anecdotes. However, as corruption becomes more of a cultural phenomenon, it becomes crucial to theorize corruption in order to be able to resist it. The problem of corruption is obvious, but defining corruption is a challenge. The word corruption comes from the Latin word corruptio, which in Medieval Latin expressed a moral decay, wicked behavior, putridity, rottenness (Johnston, 1996, p. 322). Milovanovic (2001) says that in this context one could talk of bribes, or other dishonest means for achieving particular disgraceful ends, as a symptom of an ailing society. Johnson's Dictionary defines bribe as "a reward to pervert the judgment or corrupt the conduct", while corruption is "a loss of purity and purpose, a social decomposition.” (Osborne, 1997, p. 10)

It is obvious that different authors use the word corruption in different contexts, expressing different meanings. White and Allen (2003, p. 282) point out that "Agreed upon definitions are rare, and definitions of corruption run the gamut of being too broad to be rendered relatively useless, to being too narrow and thus be applicable to only limited, rare, well-defined cases." The discussion of corruption is field specific. The literature in political science focuses on corruption in public policy. It includes rentseeking behavior (Krueger, 1974; Buchanan, et. al., 1980; Klitgaard, 1986; White, 1996; 
McChesney, 1997), the rise of state bureaucracies (Wilson, 1975; Weber, 1978), and cross-national characteristics (Treisman, 2000). The definition most cited in the political literature is given by Nye (1967, p. 419):

Corruption is behavior which deviates from the normal duties of a public role because of private-regarding (family, close private clique), pecuniary or status gains, or violates rules against the exercise of certain types of private-regarding influence. This includes such behavior as bribery (use of reward to pervert the judgment of a person in a position of trust); nepotism (bestowal of patronage by reasons of ascriptive relationship rather than merit); and misappropriation (illegal appropriation of public resources for private-regarding use).

Economics has advanced significantly in modeling corruption, but is experiencing difficulties in testing the models due to the lack of large and reliable datasets (RoseAckerman, 1978; Tirole, 1992; Bardhan, 1997). Whatever problem economists might have in explaining corruption is indicated by Rose-Ackerman's (1978) definition of corruption as an "allocative mechanism" for scarce resources. The state monopolizes certain allocative functions, be it permissions and licenses, or access to public services. State officials' profiteering is based on abuse of their discretionary powers and monopolistic positions.

The definition of corruption as it is used in economics underlines the role of the state and assumes the corruptibility of a government official. Corruption in higher education presents the need for a more inclusive definition. The challenge to an understanding of corruption as applied to higher education arises when one is confronted with cases of bribery. These may take place in private higher education institutions as 
well as in public ones. Anecdotal evidence from the Former Soviet Bloc indicates that bribery in higher education may be as common in private colleges as in state colleges and universities. Students pay bribes in exchange for good grades independently of the type of higher education institution. This urges more inclusiveness in the definition of corruption.

The definition of education corruption includes abuse of authority for material gain (Anechiarico and Jacobs, 1996). Heyneman (2004, p. 638) adds to this definition by arguing the following: "But because education is an important public good, its professional standards include more than just material goods; hence the definition of education corruption includes the abuse of authority for personal as well as material gain.” Miller, Roberts, and Spence (2005, p. 5) point to the relativeness of the term corruption and apply it to academia:

The notion of a corrupt official or other role occupant exists only relative to some notion of what an uncorrupted occupant of that morally legitimate role consists of. The notion of an academic has at its core the moral ideal, or at least, the morally legitimate role, of an independent truth-seeker who works in accordance with accepted principles of reason and evidence, who publishes in his or her own name only work that he or she has actually done, and so on. So an academic motivated by a desire for academic status who intentionally falsifies his or her experimental results or plagiarizes the work of others is corrupt relative to the ideal or morally legitimate role of an uncorrupted academic. On the other hand, a person occupying an academic position who paid no heed whatsoever to the truth or to 
principles of reasoning and evidence and who made no pretense of so doing would at some point cease to be an academic of any sort, corrupt or otherwise. The International Institute for Educational Planning (IIEP) offers defining corruption in education as a "misuse of public office for private gain that influences access, quality, and equity in education." ${ }^{2}$ Sayed and Bruce (1998) and Waite and Allen (2003) present a broad social approach to define corruption. Sayer and Bruce (1998, p. 3) present a broader social approach to definition of corruption, stating: "What is commonly meant by corruption, it places the emphasis on morality and has its roots in classical conceptions of corruption which sought not so much to identify behaviour, but to judge the overall political health of a society and its institutions." Waite and Allen (2003, p. 282) reflect that "the term corruption is any use of power or position through discrete acts or behavior(s) that benefit an individual, group, or organization." They state that their definition of corruption "must allow for states of corruption, that is, the accrual of such acts over time as to constitute a state, climate, or culture of corruption. The gains or benefits derived through corruption can be other than financial. Waite and Allen (2003, p. 282-283) point out that the definition of corruption must also allow for a normative judgment or assessment of corruption, one that is not based on strict legal interpretation but that draws from more widely held, commonplace conceptions of corruption as the deviation of a person, organization, or group from its purposes, such as when self-interest influences decisions by administrators.”

Petrov and Temple (2004) apply a narrow definition of corruption that regards corruption as such only if it implies illegality. This study adheres to Petrov and Temple's

\footnotetext{
${ }^{2}$ The International Institute for Educational Planning (IIEP), http://www.unesco.org/iiep/eng/research/research.htm
} 
(2004) approach to corruption and applies a narrow definition of corruption that regards corruption as such only if it implies illegality. It uses an operational definition of corruption in higher education as a system of informal relations established to regulate unsanctioned access to material and nonmaterial assets through abuse of the office of public or corporate trust. The task of creating a set of well-grounded definitions seems to be a primary methodological task for the problem-focused research in the field of corruption.

National laws differ and legality and illegality are not universal. Accordingly, there might be not one universal definition of corruption in higher education that would apply equally well to different national systems in different historical periods. Granting access to publicly funded higher education on any premise other than academic merit is equated to corruption. Access to higher education in exchange for a bribe is deemed to be corrupt. In the decentralized market-based systems of higher education gaining access to educational services in exchange for payments is a norm.

Corruption in universities existed long before the emergence of the market economy. Medieval universities were riddled with corruption, including bribery, laxity in examinations, and cheating. Some were but diploma mills (Compayre, 1893; Hyde, 1972; Thelin, 1982). Depending on the system and legal frameworks laid in the society, certain forms of funding, modes of operation, patterns of behavior, and standards of conduct in higher education may be considered corrupt or non-corrupt. Corruption in higher education is time and place specific.

There is a variety of forms of corruption in higher education. Corruption in higher education is not limited to bribery, or to academic corruption. Bribes are but the most 
explicit manifestations of corruption in education. Other forms of corruption include extortion, embezzlement, fraud, nepotism, cronyism, favoritism, kickbacks, cheating, and research misconduct. They rarely appear on their own. Forms of corruption are often connected in bundles. For instance, assigning a high grade to a student in exchange for a bribe implies fraud. A form itself can have different origins. A bribe can be offered voluntarily or extorted. It can be in the form of cash, merchandize, service, or a monetary donation. Gross waste in educational management, embezzlement from the state funds, and sexual misconduct that take place in higher education institutions do not represent academic corruption per se, because they are not part of academic process. Corruption develops in organizational structures that evolve and replace each other.

The problem of corruption is obvious, but defining corruption is a challenge. Waite and Allen (2003) characterize the difficulty of defining corruption as follows: "Definitions of corruption are problematic. Agreed-on definitions are rare, and definitions of corruption run the gamut from being too narrow and thus applicable to only limited, rare, well-defined cases." They suggest that the discussion of the issue of corruption seems to be entirely absent in the literature on educational administration. The task of creating a set of well-grounded definitions seems to be a primary methodological task for the problem-focused research in the field of corruption. The categorization of corruption is presented in Table 1. 
Table 1

Corruption in higher education: classification, forms, and approaches

\begin{tabular}{|c|c|c|c|c|c|}
\hline Categorization & Criteria & Classification & Forms & $\begin{array}{l}\text { Fields that study } \\
\text { Corruption }\end{array}$ & Theories applied \\
\hline Motive & $\begin{array}{l}\text { Who gains? } \\
\text { (recipients of the } \\
\text { benefits of } \\
\text { corruption) }\end{array}$ & $\begin{array}{l}\text { Individual gain } \\
\text { Institutional gain } \\
\text { Common good }\end{array}$ & $\begin{array}{l}\text { Individual } \\
\text { corruption (bribery, } \\
\text { embezzlement, } \\
\text { nepotism, } \\
\text { cronyism) } \\
\text { Institutional } \\
\text { corruption } \\
\text { (misinformation, } \\
\text { misappropriation) }\end{array}$ & $\begin{array}{l}\text { Public Policy } \\
\text { Microeconomics } \\
\text { Behaviorism }\end{array}$ & $\begin{array}{l}\text { Principal-agent theory } \\
\text { Political corruption } \\
\text { Rational behavior }\end{array}$ \\
\hline $\begin{array}{l}\text { Legal vs. } \\
\text { illegal }\end{array}$ & Legality & $\begin{array}{l}\text { Legal } \\
\text { Illegal }\end{array}$ & $\begin{array}{l}\text { Abuse, waste } \\
\text { Bribery, fraud }\end{array}$ & $\begin{array}{l}\text { Legal studies } \\
\text { Accounting and } \\
\text { Audit }\end{array}$ & $\begin{array}{l}\text { White collar crime } \\
\text { Accounting }\end{array}$ \\
\hline Locus & $\begin{array}{l}\text { Place, process, } \\
\text { stage, unit }\end{array}$ & $\begin{array}{l}\text { Education } \\
\text { Services } \\
\text { Administration }\end{array}$ & $\begin{array}{l}\text { Admission (bribes, } \\
\text { nepotism) } \\
\text { Instruction (bribes) } \\
\text { Research (fraud) } \\
\text { Health Care } \\
\text { (malpractice, fraud) } \\
\text { Management } \\
\text { (embezzlement, } \\
\text { waste, abuse, fraud) }\end{array}$ & $\begin{array}{l}\text { Higher } \\
\text { Education } \\
\text { Administration, } \\
\text { Organizations }\end{array}$ & $\begin{array}{l}\text { Finance } \\
\text { Public finance } \\
\text { Higher Ed } \\
\text { Management } \\
\text { Organizational } \\
\text { theories } \\
\text { (wide variety) }\end{array}$ \\
\hline
\end{tabular}




\begin{tabular}{|c|c|c|c|c|c|}
\hline Categorization & Criteria & Classification & Forms & Fields that study & Theories applied \\
\hline Intensity & $\begin{array}{l}\text { Measurability } \\
\text { Density } \\
\text { Total volume } \\
\text { Average size } \\
\text { Distribution } \\
\text { (monotonicity } \\
\text { and inequality) }\end{array}$ & $\begin{array}{l}\text { Measurable } \\
\text { (quantified), } \\
\text { unmeasurable } \\
\text { (unquantified, hidden) } \\
\text { Case by case, rare, } \\
\text { common, widespread, } \\
\text { systemic } \\
\text { Large, medium, small } \\
\text { Large, medium, small } \\
\text { Monotonic, sporadic } \\
\text { Equal, unequal }\end{array}$ & $\begin{array}{l}\text { Bribery (monetary, } \\
\text { non-monetary) } \\
\text { Waste } \\
\text { Abuse }\end{array}$ & $\begin{array}{l}\text { Statistics for } \\
\text { Business and } \\
\text { Management }\end{array}$ & $\begin{array}{l}\text { Theories of } \\
\text { distribution } \\
\text { Probability theory }\end{array}$ \\
\hline Function & $\begin{array}{l}\text { What is } \\
\text { achieved? }\end{array}$ & $\begin{array}{l}\text { Equilibrium } \\
\text { Market vs. State } \\
\text { Reform } \\
\text { Income generation }\end{array}$ & Bribery, & $\begin{array}{l}\text { Macroeconomics } \\
\text { Political } \\
\text { Economy } \\
\text { Transition } \\
\text { economics } \\
\text { Microeconomics }\end{array}$ & $\begin{array}{l}\text { General equilibrium, } \\
\text { Rational expectations, } \\
\text { Resource Allocation } \\
\text { Economic security, } \\
\text { Public sector, } \\
\text { Government } \\
\text { intervention, } \\
\text { "grabbing hand" } \\
\text { theory } \\
\text { Institutional theories } \\
\text { "Grease in the } \\
\text { wheels" or "speed } \\
\text { money" } \\
\text { Theory of firm } \\
\text { "Red tape" theory }\end{array}$ \\
\hline $\begin{array}{l}\text { Utility } \\
\text { (impact) }\end{array}$ & Effects & $\begin{array}{l}\text { Cost } \\
\text { Benefit }\end{array}$ & $\begin{array}{l}\text { Bribery } \\
\text { Embezzlement } \\
\text { Inefficiencies } \\
\text { Waste, abuse, fraud }\end{array}$ & $\begin{array}{l}\text { Development } \\
\text { economics } \\
\text { Theory of firm }\end{array}$ & $\begin{array}{l}\text { Cost-benefit analysis } \\
\text { Theory of monopoly }\end{array}$ \\
\hline
\end{tabular}


Based on the synthesis of media materials and legal records, this study derives a grounded category of corruption in higher education. Definitions of corruption such as "abuse of public office for personal gain" are too broad and lack specificity. This research asserts that the definition of corruption as abuse of public office for private gain is convenient in that it is inclusive. The strength of the definition, then, is in its inclusiveness, but its weakness is that it is not specific. The definition is very general and may be applied to many aspects of the public sector, but it does not disclose the essence of corruption. Its applicability to the private sector is also unclear.

This study employs a different conceptual understanding of corruption. This understanding is based on the principle of historicism and rationality and can be formulated as follows: Corruption is a net or a system of relations that 1) includes property relations, 2) exists between individuals and institutions that enter and maintain these relations on the basis of both voluntary and involuntary participation, 3) is based upon fundamental socio-economic conditions within specific institutional and time frames, 4) serves as a mechanism for distributing and redistributing wealth and power, 5) functions in the regimes of decreased, constant, and increased scale, 6) violates current laws, norms, and formal procedures existing within a society, and 7) is either recognized or not recognized as corruption by different groups of people.

Corrupt activities in certain settings and contexts may be rational, depending on an environment, organizational climate and culture. Rawls states that the reasonable and the rational cannot be derived from each other and that reasonable people propose fair terms of cooperation, that cannot be substituted by an agreement based on corruption. But the reasonable exists within certain organizational systems and is not solely a 
characteristic of the society overall. A corrupt person may well be characterized by other members of society as reasonable, rational, and cooperative.

Often groups reach an agreement to satisfy their interests and this agreement may be based on corruption. Participating in corruption may be more beneficial and less risky than non-participating. In this case cooperative behavior may seem to be more rational and reasonable than non-cooperative. This type of reason, however, is not a public reason but one of persons and organizations. This is not a Rawls's reasonableness in its political meaning. Even though corrupt practices are widespread and lead to an agreement, they do not represent a public reason, defined by Rawls (1993) as a characteristic of a democratic people. Corruption has an overall negative impact on society and so is obstructive to public good and fundamental justice.

While Rawls's approach might be characterized as somewhat idealistic, an historical determinism-based approach is derived from the specific socio-economic conditions, under which every particular event, activity, institution, or rule may be characterized as corrupt or otherwise, independently of moral and ethical constructs. This research develops a category of corruption based on corruptio that means "perversion of purpose."

Corruption in higher education is detrimental to the society for at least two major reasons. First, it has a negative impact on the economy and society due to the lowered efficiency of the system, as does bureaucratic corruption. But, in the distinction of ordinary bureaucratic corruption, corruption in higher education reduces the total social welfare of the society because of its negative effect on the quality of educational programs and qualifications of college graduates. Moreover, unqualified specialists may 
pose a threat to the society through their professional activities. For instance, doctors with low quality education will not be able to provide proper or best treatment to their patients. Civil engineers will construct poor buildings that may fall, etc. This consideration of social welfare imposes especially high moral standards on college faculty as educators as well as controllers of education quality and skills of their graduates.

In times of major socio-economic transformations it is unclear what is and what is not allowable, and what are the basic rules. Faculty members who are involved in corrupt activities often do not know the rules, interpret the rules in their favor, and as well arrange and adjust the rules. Moral and ethical considerations are replaced with an economic rationale. The only ground here is a mainstream of socio-economic development, at the top of which there is a new, i.e. adjusted old social order with its new laws and regulations. These new rules are only observed and followed if they adequately reflect reality. Unfortunately, the new rules most often reflect quasi-reality, i.e. the reality that exists in people's imaginations and ideals about fairness and a better social order as well as political proclamations, and so breaking a law means moving toward equilibrium in socio-economic relations rather than violating such an equilibrium.

To summarize, it is sometimes good to be corrupt. It is good to be corrupt for the academically unsuccessful student to make his/her way through the college. It is good to be corrupt for a professor to survive financially and maintain good relations with the university administration. It is good to be corrupt for the administration, to retain its student body and maintain the financial soundness of the university. And it is good for the government to have corrupt universities, because it is easier to make them loyal and comply with government policies, whatever unfair they may be. 


\section{Informative base of the study}

The informative base of the study consists of the following major sources:

- scholarly publications, including those in the fields of educational policy, development economics, political science, public policy, sociology, and organizational theory;

- publications in the mass media, including periodical editions and on-line news editions;

- legal cases and court records;

- on-line resources, including reports on corruption.

\section{Research methodology}

While a categorization of corruption has been in stages of development and revision over the last two decades, the methodology of studying corruption is at best in its infancy. There are two major methods applied in research on corruption. Economists tend to focus on survey-based quantitative methodologies. In political science and public policy the methodology of research on corruption is narrowed down to case studies, and resembles more closely investigations and journalistic-style commentaries, rather than rigorous scholarly work. Interviews are another approach to investigate corruption in large organizations and industries. 
Due to the secrecy and illegality of the subject matter in research on corruption, one of the major challenges is the reliability of data. Moreover, the research is often focused on corruption in developing countries where obtaining reliable data is an immense challenge. Quantitative methodologies of studying corruption in higher education can rely heavily on the works of Babbie (1995), Johnston (2001), and Kaufmann (1998).

As data are crucial to quantitative research, identification of sources for data collection and the process of collection itself are considered in this discussion. Such characteristics of the data, as validity, reliability, and preciseness are important. Measurements of corruption may be separated into the measurements of effects of corruption or impact on the economy and other aspects of life, measurements of corruption itself, and measurements of the dynamic of corruption and its effects. Svensson (2005) notices that in a quantitative analysis of corruption all reliance is on the likely correlation between different forms of corruption.

Corruption is a complex and multifaceted phenomenon that can take many forms. Noonan (1983, p. 43) says: "Corruption is an unquantified phenomenon; it is impossible to say whether the multiplication of laws and prosecutions is reducing it, keeping even with it, or falling behind. In the absence of a quantitative basis for evaluating the efficacy of criminal laws in this area, the success of the law is measured in terms of its symbolic impact." Measuring corruption is necessary not only for understanding the scale and scope of the problem in higher education, but also for making simple comparisons between countries and conducting comparative analysis of corruption in national educational systems. 
Johnston (2001, p. 157) notes:

Other than the question of definitions, few issues have so thoroughly stymied the comparative study of corruption as that of measurement. Types and amounts of corruption vary among, and within, societies. Theory tells us that these contrasts reflect political and economic influences, history, and culture, and in turn affect societies and their development in important ways. But the difficulty of measuring corruption has long made it difficult to make such comparisons, to test hypotheses, and to build sound, comprehensive theories.

Johnston (2001, pp. 160-166) raises several concerns about measurement, including reliability, precision, and validity as well as "bribery bias," all of which are equally important for international corruption rankings and comparative analysis of the levels of corruption in different countries. In his view, the following question might be of primary importance: "can we devise relatively inexpensive measures that are still sensitive to changing levels of corruption, and can give useful guidance to anticorruption efforts?" (Johnston, 2001, p. 172) He suggests looking into scaling correlates of corruption rather than attempting to measure corruption itself. This assumption that certain conditions and the phenomenon of corruption itself are closely linked may be mapped at the opposite end of the vector of measuring effects of corruption, so popular in development economics, rather than internal changes in corruption.

Kaufmann (1998) suggests that the measurement of corruption should be focused on different types of abuses, different types of public offices, some types of private gains, and factors influencing such abuses. His typology of corruption focuses entirely on the public office and by definition has serious limitations. While considering corruption in 
higher education, one should admit the fact that corruption in its different forms takes place in private higher education institutions as well as in public ones, and is not necessarily connected to the different levels of government or state bureaucrats and public officials. Kaufmann (2005, pp. 150-155) considers such aspects of corruption as bribery for ignoring counterproductive regulations and getting around socially necessary regulations, as well as misappropriation of public budget and patronage. The author presents a methodology for measuring corruption as related to public offices, based on surveys and hard data analysis. He further suggests focusing on public agencies and financial transparency as well as such characteristics as reliability, prioritization, and integration of the various approaches.

As may be seen from the most recent work on corruption in education (Cahn, 1986; Sykes, 1987; Noah and Eckstein, 2001; Anderson, 1992; Segal, 2004; Washburn, 2005), case studies supplemented with superficial analysis constitute the bulk of what might be interpreted as a research methodology. The multiplicity of cases of corruption referred to in these studies pushes them beyond the borders of a simple case study, yet they remain insufficient to move into the realm of quantitative research. At the same time, this overload of cases does not carry with it a sufficient portion of analysis and synthesis and other qualitative methods that would be of great benefit to the research. At this stage, research on corruption in education, and higher education in particular, is almost nonexistent. Accordingly, the methodology used in first attempts to investigate the issue may at best replicate methodology used in the field of development economics and in the field of public policy. 
As higher education becomes more of a business-like industry, methodology borrowed from white-collar crime theories might also be of help. Imports of categorical apparatus and research methodology from these fields and their adaptation to the field of education, and higher education in particular, might be the major task for future research on education corruption. Development of research methodology in the fields of development economics and public policy will facilitate a further development of the categorical apparatus. These developments will further be utilized in studying corruption in education. The two major parts of the study will include an investigation of the media reflections on corruption in higher education and a research of the legal record on the cases of corruption in higher education.

The first part of the study considers corruption in higher education in the media, following publications in the United States (US), the United Kingdom (UK), and the Russian Federation (RF). It addresses the question: How is corruption in higher education reflected in the world media, what particular aspects of corruption receive more of the media's attention and why? Specifically, it analyzes selected publications in two major international languages, English and Russian, for the period of 1998-2007, devoted to corruption in higher education.

The categorization of corruption in higher education for this study includes means, forms and phenomena, spheres where it exists, and areas of interaction where it is found. The means are: bribes, kickbacks, kinship, personal connections, reciprocity (exchange of favors), and fraud. The forms and phenomena include: bribery, nepotism, favoritism, fraud, embezzlement, cheating, plagiarism, ethics misconduct, and breach of contract. The spheres are: access to higher education, academic process, graduation, credentials, 
licensing and accreditation, faculty hiring and promotion, research, grants, medical services. The interactions include: state-university, business-university, faculty-students, faculty-administration, students-administration, and state-students relations.

The second part of the study considers corruption in higher education through legal records, following publications and court cases in the US and the RF. The major focus here will be on the few selected cases of corruption in US higher education. These cases are broadly publicized in the media. They are significant and affect large number of higher education institutions and constituents, including educators, students, parents, and general public. The legal cases to be analyzed are at the core of the development and the reform of the higher education industry. They reflect processes of decentralization, commercialization, and marketization of higher education along with the processes of coordination, quality assurance, and state control in the industry.

The task of this part of the study is to address the question: How is corruption in higher education understood and defined in court cases, what particular cases receive more attention, and how do these cases correlate with the major educational reforms, changes, and socio-economic context in the nation? Specifically, it analyzes records of selected legal cases devoted to corruption in higher education. The cases of corruption in higher education considered in courts include fraud in educational loans, quality of educational programs, credentials, credentials evaluation and accreditation, attempts to monopolize discretion over the admissions decisions, collusion, embezzlement, research misconduct, and medical fraud.

The case of the US versus University of Phoenix in 2006 points to the federal funds received by the University in form of student aid. The University might have been 
ineligible because of non-compliance with certain federal laws and regulations. The case is being developed on the ground of the False Claims Act and anticipates possible fraud in state-university relations. Chapman University received federal funds in the form of student aid, but might have been ineligible as well. The major challenge in the case considered in 2006 was the time necessary to receive credit hours. As a result, students might have been defrauded because of insufficient instruction time and the state was defrauded as well.

Possible corruption takes place in student-university relations and in stateuniversity relations. The State of New York Attorney General launched an investigation in 2007 to discover some doubtful practices with student loan preferred lists, administered by colleges' financial aid officers. The case points to possible attempts to establish a near-monopoly and to defraud students in local markets of educational loans. The case involves state-university relations and student-universities relations. The government conducts the investigation on students being defrauded and guided to more expensive loans by college administrators.

One of the major cases that attempted to establish possible corruption in admissions involved MIT and a number of other Ivy League colleges in 1990. The colleges were making agreements prior to admitting graduate students in order to reduce the total cost of the offerings in form of scholarships and financial aid. This implies monopoly in admissions, collusion, and consumer fraud. The colleges admitted wrongdoing and stopped the practice, while MIT won on appeal, pointing to its nonprofit status. Another broadly publicized case of 1985 involved Stanford University and later a few other colleges. The major consideration here was overcap payments of up to 
72 cents on every $\$ 1$ received in the form of federal grants as well as the ways in which some of the federal research money was spent. The case implied possible fraud in stateuniversity relations. A number of cases with diploma mills involved state-university relations, consumer-university relations, and degree holders-employers relations. Cases of educational quality fraud involve consumers or students, providers or colleges, and accreditation agencies. Research fraud involves the state as the major source of funding while medical fraud committed in university hospitals involves patients and insurance companies.

The cases of corruption in higher education selected for the study include most recent developments in college funding, including ties between colleges and the educational loans industry. The investigation was initiated by the Attorney General of the State of New York, Mr. Cuomo, and followed by another 27 states throughout the country. Two other cases may include a for-profit educational institution based in California that was accused by the state in defrauding its students, playing on the mismatch of students' financial aid and academic abilities and agreed to a settlement of $\$ 6.5$ million in restitutions, penalties, fines, and compensatory payments, and the case with the University of Phoenix based on the False Claims Act.

The case may necessitate development of certain measures, such as the Consumer Education Fund established by the Attorney General, as well as changes in legislation, designed to prevent doubtful practices in the future. Provision of private educational loans is a growing industry in the US. It rose sharply from $\$ 1.7$ billion in 1996 to $\$ 17$ billion in 2006 and is expected to grow continuously and rapidly in the future. Similar developments may take place in other nations in the future. The process of transferring 
education financing to private educational loans represents the major trend in higher education funding and may soon be borrowed and adopted in other countries.

Subsequently, legislative regulations and changes in the legislation are necessary as well as provisions in the university's code of conduct not only in the US, but in many other nations.

The classification also points to some possible theoretical developments. The core of the problem as related to corruption is in an intentional restriction of students' access to reliable information about available educational loans. This implies imperfect information, imperfect competition between the educational lenders, and a certain degree of monopolization of the market of educational loans and eventually brings into fore the antitrust law.

A grounded theory approach will be utilized to develop theoretical extensions based on the analysis of media reports and legal cases of corruption in higher education. These theoretical extensions will present explanations of how the corrupt systems in higher education function, based on what grounds, and how they evolve and develop in existing and changing socio-economic contexts. According to Moghaddam (2006), “The grounded theory approach consists of a set of steps and processes which are the building blocks of a quality grounded theory. Grounded theory... focuses on making implicit beliefs explicit." (p. 1) Grounded theory refers to theory developed inductively from data (Charmaz, 2000). Grounded theory was introduced in 1967 to present a reliable way of connecting for diverse facts into an explanatory theory when "data are fractured, conceptualized, and integrated to form theory" (Strauss and Corbin, 1998, p.3). Referring to Creswell (2002), Moghaddam (2006, p. 1) points out that "What Glaser and Strauss 
suggested as grounded theory is actually a 'systematic, qualitative process used to generate a theory that explains, at a broad conceptual level, a process, an action, or interaction about a substantive topic"”

The grounded theory approach is specifically designed to address issues that have not been well researched. Corruption in higher education remains a theoretically undeveloped problem. Even a simple theoretical description of the phenomenon of corruption in higher education industries of different countries is virtually absent. According to Moghaddam (2006), "The strongest cases for the use of grounded theory are in studies of comparatively unexplored areas." (Moghaddam, 2006, p. 2, as referred to Samik-Ibrahim, 2000) The grounded theory approach is used to generate a new explanatory theory rather than use one 'off the shelf' to enlighten a procedure, action, or interaction, a step-by-step, systematic process to stay close to the data (Creswell, 2002). Grounded theory may be applied to the areas where no extensive scholarly literature exists.

Based on the foundations of grounded theory, the basic strategy that may be applied in studies of corruption in higher education may be formulated as the sequence of the following steps:

- Identification and demonstration of relevant and necessary grounds for corruption to exist, including intensity of monetary transactions in the system;

- Identification of preconditions for corruption to exist, including complexity of the system, presence of the comprehensive legal system, and discretion, delegated to public officials. All of these should be carefully weighted on the scale of their relative values, significance, and level of development. 
- Specification of the necessary conditions for corruption. These may include an imperfect legal system and an imperfect market system. Defining conditions for corruption will depend upon the concepts and frames used to determine and categorize corruption.

- Presenting evidence of corruption by using illustrative techniques borrowed from both quantitative and qualitative methodologies.

- Describing building blocks of corruption in the industry.

- Presenting a system of corruption as a whole, with its net of interrelations and agents participating in such net. This will involve intensive use of the method of analysis and synthesis and lead to generalizations.

- Finally, generalization will be used as a platform or a starting point for deduction. Deduction will allow for identifying otherwise invisible pockets of corruption.

The method of induction may be used in studying corruption in higher education based on particular cases. According to Bernard (2000, p. 493), "Analytic induction is a formal, qualitative method for building up causal explanations of phenomena from a close examination of cases. The method involves the following steps:

(1) Define a phenomenon that requires explanation and propose an explanation.

(2) Examine a single case to see if the explanation fits.

(3) If it does, then examine another case. An explanation is accepted until a new case falsifies it."

Dubs (1930, p. 127) describes a four-step process of testing inductive generalizations in the following way: "General procedure for the logical testing of a 
rational inductive generalization consists, first, in the formulation of a hypothesis; second, in the elaboration of the consequences of that hypothesis, which is deduction; third, in the checking of those consequences with experience, to see whether they are exactly found in experience, which is often by immediate description; and fourth, in the judgment as to whether the hypothesis has been verified (is true) or not."

Generalized induction will be used to apply conceptual frames borrowed from economics, political science, organizational theory, and education to build a new theory on the ground of factual material that comes from the media, legal cases, data, and online resources. Media reports on corruption in higher education are based on people's perceptions about corruption, people's personal experiences, and legal reports that either prove or disprove facts of corruption in the education industry. But perceptions shape future corrupt behavior of individuals and educators as well. This further increases the significance of media reports on corruption in higher education.

Legal cases are also of high significance, because they have a potential to establish legal precedents, lay the ground for future legal regulations, and shape public perceptions about fairness of the system and the scale of corruption in higher education. The utilization of the two major sources available--legal cases and media reports-with the focus on different types of national higher educational systems will add to the value of this study through its comparative, international, and interdisciplinary perspectives.

\section{Limitations of the study}

The research carries some limitations. First, the areas left unattended in 
categorization of corruption include gross waste and misallocation of the resources. Gross waste and misallocation of the resources constitute a so-called grey area of corruption in education, especially when personal or material gains are not pursued. Even though gross waste and misallocation of resources is detrimental to higher education, in most instances it does not constitute an illegal act, unless personal benefit is pursued. The same is true with mismanagement of higher education institutions. While systemic mismanagement has a negative impact on the health of academia, it is not considered an act of corruption as long as it does not include embezzlement, fraud, or other illegal activities. Second, the legal records available for the study are those from the US. While investigations and court rulings on corruption in higher education in the RF are highlighted in the media, the court records are unavailable. Third, some basic statistics on corruption in higher education in the RF and other countries of the former Soviet Bloc are obtained by the researchers from the open sources in both Russian and English languages, while in the US such statistics are lacking. These limitations, however, will not prevent from accomplishing the goal of the study. 


\title{
CHAPTER II
}

\section{HIGHER EDUCATION CORRUPTION IN THE WORLD MEDIA:}

\author{
PREVALENCE, PATTERNS, AND FORMS
}

\section{Introduction}

Corruption in higher education is a newly emerging topic in the field of education research. Scholarly work on corruption in higher education is lacking while the problem itself is significant. The presence of corruption in higher education throughout the world is a growing concern for the industry as it influences its effectiveness and efficiency. ${ }^{3}$ The negative impact of higher-education corruption on economic development and social cohesion is also disturbing. ${ }^{4}$ With the rapid internationalization of higher education and the growing volume of trade in educational services, matters of educational credentials-and credibility in general--become ever more important. ${ }^{5}$ This chapter considers

${ }^{3}$ There are numerous media sources that include publications focused on different aspects of corruption in higher education internationally. An excellent selection of media titles devoted to corruption in higher education may be found at the Center for International Higher Education at Boston College.

${ }^{4}$ See, for instance, Silova, Iveta, Mark Johnson and Stephen Heyneman. (2007). Education and the Crisis of Social Cohesion in Azerbaijan and Central Asia. Comparative Education Review, 51(2) (May), pp. 159-180.

${ }^{5}$ See, for instance, Altbach, Philip, and Jane Knight. (2006). The Internationalization of Higher Education: Motivations and Realities. In The NEA Almanac of Higher Education. Washington, DC: National Education Association.; De Wit, Hans. (2002). Internationalization of Higher Education in the United States and Europe: A Historical, Comparative, and Conceptual Analysis. Westport, CT: Greenwood. For the issue of international credentials recognition see Heyneman, Stephen, Kathryn Anderson, and Nazym Nuraliyeva. (2007). The Cost of Corruption in Higher Education. Comparative Education Review, forthcoming, p. 26. 
corruption in higher education as reflected in the world media, including such aspects of corruption as its prevalence, patterns, and dominating forms. The findings help to determine which aspects of corruption should be given more consideration in future research and which ones might be prioritized.

\section{Research question}

The research of corruption in higher education does not face the lack of methodological approaches, as they may be borrowed from other disciplines, including political science and economics. At the same time methodological approaches, borrowed from other disciplines and applied to corruption, have certain limitations. Petrov and Temple (2004) say that the methodology of studying corruption in education may be no different from qualitative research. However, some problems are encountered by the researchers. For instance, faculty members know of each other's corrupt activities but do not discuss them. As a result, major difficulties arise when collecting information due to specifics of the topic - corrupt practices remain illegal.

Another problem that researchers may face is the low level of reliability of the information obtained from surveys and interviews. Not only does the media reflect perceptions, problems, and trends, but it also shapes perceptions about corruption. Hence, the media is important in researching corruption not only as a reflector from which people collect information, but as an instrument of shaping and facilitating corrupt behavior as well. Moreover, it is noticed by several authors that perceptions of the public about corruption lead to an increase in the number of incidences of corruption and the 
total volume of benefits obtained through corrupt ways (Cabelkova and Hanousek, 2004; Tumennasan, 2005; Olken, 2006). An increase in public perceptions about corruption in higher education facilitates a further increase in corruption as well as the total amount of corrupt benefits accumulated by the college instructors and administration. This underlines the importance of the media as a signaling agency that informs the general public about corrupt practices, customs, and norms. Democratic changes and processes of openness and transparency increase the role of the media in the society.

This chapter considers corruption in higher education in the media, following publications in the United States (US), the United Kingdom (UK), and the Russian Federation (RF). The research question can be formulated as follows: How is corruption in higher education reflected in the world media, what particular aspects of corruption receive more of the media's attention and why? Specifically, this chapter analyzes selected publications in two major international languages, English and Russian, for the period of 1998-2007, devoted to corruption in higher education. This recent period has been selected because all of the sources are available on-line and consequently have much broader outreach than they had before. Other research questions include: Which forms of corruption in higher education are given most attention, which ones are underrepresented, and why? How do the media in one region comment on corruption in higher education in other regions? How does the media coverage of corruption in higher education correlate with the statistical data on the prevalence of corruption in each region? And how do all of these correlate with the major educational reforms, changes, and socioeconomic context in each of the nations in general?

Different aspects of corruption in higher education are reflected in just about 
every news source or edition. The research has chosen sources that provide the most comprehensive reflection on both nationwide and international problems, including the entire spectrum of the problems associated with higher education corruption. These sources consider significant cases of corruption, broadly discussed in the society. They present stories built of information obtained from reliable sources and have a high level of credibility.

\section{Research methodology}

This research identifies one source that specializes in higher education and one major news source for each of the regions, including North America (the US), Europe (the UK), and the former Soviet Union (the RF) with populations of approximately 300, 60, and 150 million, respectively. These countries represent different models of higher education organization, including such key aspects as governance, management, funding, and admission policies. The selected on-line non-scholarly publications in the US and the UK can be accessed only for a fee, while publications in the Russian Federation are accessible for free. All of the publications are not limited to the national borders, instead having a much broader outreach.

In the US, the focus is on The Chronicle of Higher Education, a specialized edition, and The New York Times, a non-specialized edition; In the UK, this research reports on corruption in higher education in The Times Higher Education Supplement, a specialized edition, and The Guardian, as a non-specialized edition; in the RF, this chapter investigates on-line editions of Gazeta.ru, a non-specialized edition that has a 
substantial regular section on higher education, and Newsru.com, a non-specialized edition. All of the media sources presented above address to a certain extent both domestic and international issues in higher education.

The publications are grouped depending on the particular problem they address. This criterion has been chosen as best addressing the issue of corruption internationally. The groups are as follows: corruption in access to higher education, including violations in national and international educational tests, violations in entry examinations, and bribery; corruption in research and research grants, including violations of the rules of conduct, presentation of results known to be incorrect, fraud, plagiarism, and corruption in obtaining grants; corruption in academic process, including low quality of instruction, unearned diplomas, degrees, and educational certificates, cheating, plagiarism, collusion, diploma fraud, production, distribution, sale, and usage of fraudulent certificates, diploma mills, term papers for sale, including those exchanged through the internet; corruption in auxiliary activities, including intercollegiate athletics; industry-specific corruption in higher education management and administration, including fraud, embezzlement, and provision of false information; corruption in auxiliary branches, including academic publishing, development and provision of educational software, and supply of educational services and goods. Classification of corruption in higher education used in this study is presented in Table 2 . 
Table 2

Criteria used and classification of corruption in higher education

Phenomenon. What takes place?

Bribery of all types and forms

Nepotism: kinship

Favoritism: preferential treatment

Fraud: research fraud, healthcare fraud, non-compliance, managed and biased information flow

Embezzlement: from the university, by the university

Cheating: by students, prospective students

Plagiarism: by students, faculty

Ethics misconduct, including sexual misconduct

Breach of contract

Means. What means are used in corrupt activities to achieve certain goals?

Bribes: monetary, non-monetary (services etc.)

Kickbacks: monetary (normally a percentage of the total contract value)

Kinship: relatives

Personal connections: relations

Reciprocity: exchange of favors

Fraud: fraudulent documents, claims,

Locus. What are the areas and processes that get corrupted?

Access to higher education: tests (SAT, CET, TOEFL, GRE, GMAT, LSAT, GSE), admission decisions, entry examinations, donations, gifts, corporate sponsorship

Academic process: grades, additional time for ADDs, time to a client/consumer (student)

Graduation: gifts, petitioning, banquets, etc.

Credentials: diploma mills, transfer of credits, fake diplomas

Licensing and accreditation: provision of services below established standards (have to pay)

Faculty hiring and promotion: bribes, nepotism, expectation of favors, pass-overs, discrimination

Research: fraud

Grants: embezzlement

Healthcare: time to a client/consumer (patient)

Interactions. What are the interactions, relations where corruption takes place?

State-university: funding, student financial aid, grants, non-profit status, taxation

Business-university: research with biased results, educational loans, healthcare fraud

Faculty-students: all kinds of bribes, misconduct, underpaid and free services

Faculty-administration: unfair treatment, promotions, dismissals

Students-administration: breach of contract

State-students: financial aid fraud, aliens

Source: completed by the author 
The research carries some limitations. The areas left unattended in categorization of corruption include gross waste and misallocation of resources. Gross waste and misallocation of resources constitute so-called grey area of corruption in education, especially when personal or material gains are not pursued. Even though gross waste and misallocation of resources is detrimental to higher education, in most of the instances it does not constitute an illegal act, unless personal benefit is pursued. For instance, investments in university presidents' residences and renovations, addressed only in US media, are considered by some as misallocation of the university resources. While the merit of such investment may be arguable, the legality of it stays intact. The same is true for mismanagement in higher education institutions. While systemic mismanagement has a negative impact on the health of academia, it is not considered as an act of corruption as long as it does not include embezzlement, fraud, or other illegal activities.

The key words used in the search within the identified sources include: accreditation, admissions, bribe, bribery, cheating, college, corruption, degrees, diploma mills, education, embezzlement, examinations, fake, favoritism, fraud, higher education, higher education institution (HEI), misconduct, nepotism, plagiarism, research, tests, university, as well as cross-references of all of the above. Each media report on corruption-related issue in higher education is read, analyzed, and assigned a place according to the developed classification. The classification itself is being enriched in the process of analyzing the news on corruption in academia. For instance, the mafiauniversity relations subcategory is added to the Interactions section of the Classification, based on the reports about the existing connections between the mafia and a higher 
education institution in Italy. ${ }^{6}$

\section{Major findings}

The following results were obtained based on the detailed description of classification and criteria of corruption in higher education. The media points to the presence of the phenomenon of corruption in the three national systems of higher education. This phenomenon manifests itself in bribery of all types and forms, including offering and accepting money. Bribery is most common in the RF with bribes paid in cash, including in national and foreign currency and through personal account transfers. ${ }^{7}$ Bribes are also offered in the form of commodities, including durable goods and nondurable goods, services, and sex. Forms of corruption are not limited to bribery in cash and goods and services. The phenomenon of corruption also includes exchange of favors based on the principle of reciprocity as well as nepotism, including preferential treatment based on kinship. Another form of corruption discussed in the media is favoritism. This includes preferential treatment, based on personal favors.

Fraud as a phenomenon of corruption is known to have few forms. First, there is research fraud that takes place in research universities, where generation of new

\footnotetext{
${ }^{6}$ See Bollag, B. (2000). The academy and the mob. The Chronicle of Higher Education, (December 1), p. A51; Bollag, B. (2000). 37 at Italian university charged with Mafia ties. The Chronicle of Higher Education (November 3), p. A52.

${ }^{7}$ Lemutkina, Marina. (2004). 50\% roditelej platyat prepodavatelyam vztyatki [50 percent of parents pay bribes to faculty members]. Gazeta.ru (February 17); V Rossii v 2003 godu roditeli potratili na vziatki 26,5 milliarda rublei na obrazovanie svoih detei [In Russia in 2003 parents have paid 26.5 billion rubles in bribes for their children's education]. Newsru (June 24, 2004); MVD: vziatki v obrazovanii dohodyat do milliona rublej [Ministry of the Interior: size of a bribe in education reaches one million rubles]. Gazeta.ru (June 10, 2006).
} 
knowledge is one of the major functions along with teaching and learning. Research fraud occurs when research procedures are adjusted or misused to meet the interest of involved parties, and results are misreported to meet certain expectations. ${ }^{8}$ A well-known form of research fraud in the US and to a lesser extent in the UK is the biasness of pharmaceutical research conducted in universities and funded by pharmaceutical companies. ${ }^{9}$ Data manipulations in medical research may eventually lead to serious consequences for patients.

Second, there is healthcare fraud that takes place in university hospitals, medical centers, and other medical facilities that operate under the auspices of higher education institutions. Healthcare fraud occurs when patients and/or insurance companies are overcharged for the services performed, charged for services not performed, or services are not rendered appropriately according to the set procedures. This type of fraud is not related to academic process per se, unless medical treatment is a part of training for medical students.

Third, fraud in higher education can mean a concealed non-compliance, when federal and state laws are broken for personal and/or institutional benefit. Such cases may be prosecuted under the False Claims Act. For instance, this law was applied to the

${ }^{8}$ Brainard, J. (2000). As U.S. releases new rules on scientific fraud, scholars debate how much and why it occurs." The Chronicle of Higher Education (December 8), p. A26; Guterman, L. (2004). German university revokes Ph.D. of scientist who falsified data as a Bell Labs researcher. The Chronicle of Higher Education (June 16); Jacobson, J. (2005). MIT fires biology professor who admitted faking data. The Chronicle of Higher Education, 52(12) (November 11), p. A13.

${ }^{9}$ Eichenwald, K., \& Kolata, G. (1999). A doctor's drug trials turn into fraud: research for hire. New York Times (May 17), pp. A16-17; Bernstein, N. (1998). Charges of research fraud arise at Cornell AIDS lab. New York Times, (September 26), pp. A1, B6. Boseley, S. (1999). Independent body needed to curb fraudulent research. Guardian Weekly (September 16-22). 
University of Phoenix in 2007. This private for-profit institution of higher education that operates in multiple locations in the US and enrolls over fifty thousand students was accused in using enrollment practices and pay-for-performance scales for its admissions officers that would go in contradiction with the federal laws. The non-compliance with the law makes vulnerable those university revenues that come from the federal student financial aid packages. If the lawsuit is lost, the non-compliance can cost the university billions of dollars. ${ }^{10}$

Fourth, fraud exists in the form of managed and biased information flow, including having preferred educational loan providers list, as is the case in many colleges throughout the US. Financial aid officers and college administrators in several states were accused of conflict of interest in expectation of personal and/or institutional benefits, such as possible kickbacks, and profit-sharing in exchange for cooperation with private lenders. ${ }^{11}$ Transgressing rules and procedures may be a commonplace yet not addressed practice, until it amounts to a large-scale problem with a clearly visible negative impact

${ }^{10}$ Van Der Werf, M. (2006). Federal Appeals Court reinstates False-Claims lawsuit against U. of Phoenix. The Chronicle of Higher Education, 53(4), (September 15), p. A33. The case contends that the university, which is part of the Apollo Group, a publicly traded corporation, paid recruiters on the basis of how many students they could get to enroll. The U.S. Department of Education prohibits institutions from giving "any commission, bonus, or other incentive payment based directly or indirectly on success in securing enrollments." The university certified that it was in compliance with all federal regulations when it applied for eligibility for Pell Grant funds and other federal money under Title IV of the Higher Education Act.

${ }^{11}$ See, for instance, Field, Kelly, \& Keller, Josh. (2007). Cuomo Accuses Education Dept. of Lax Oversight of Lenders: In Continuing Scandal, Aid Administrators Develop New Code of Conduct. The Chronicle of Higher Education, 53 (May 4), p. A33; Field, Kelly. (2007). College Board Drops Student-Loan Program. The Chronicle of Higher Education, 54 (September 7), p. A34. There is total of over 40 publications on the issue of student loans and associated fraud and different defrauding techniques in The Chronicle of Higher Education in 2007. All of these publications are based on the results of the continuing investigation conducted by the Attorney General of the State of New York Mr. Cuomo. 
on certain groups of stakeholders and the society in general.

Embezzlement as a phenomenon of corruption in higher education works in two major directions: embezzlement from the university, committed by university employees, and embezzlement by the university, including misappropriation of research grants from the government. Both of these forms may qualify for white collar crime. ${ }^{12}$

Cheating is yet another phenomenon of corruption, reflected equally in the media in the US, the UK, and the RF. Cheating is committed by students in tests and examinations and by prospective students in entry examinations and national tests regarded as entry examinations. ${ }^{13}$ Cheating should not be considered as a relatively innocent or less explicit form of corruption, as compared to bribery. Buying a term paper on-line often replaces the need to pay a bribe. In this case the faculty member is not involved in corruption, but the student achieves the same goal of receiving unearned grade or admission to a college.

Plagiarism is committed both by students in writing academic papers and by

${ }^{12}$ One of the investigations reflected in the Newsru reports that former president of the Lugansk branch of the Inter-Regional Academy of Personnel Management (MAUP) embezzled 831.9 thousand UAH. See: Byvshy rector luganskogo filiala MAUP prisvoila 831,9 tysyach griven. CityNews (December 25, 2006). Gazeta.ru reports on the audit of the Russian department of education Oversight, conducted by the Attorney General's Office. The Department is being accused in wasteful spending of around 30 million rubles. See, for instance, Lemutkina, Marina. (2006). Genprokuratura poshla na ediny ekzamen [The Attorney General's Office took up on the standardized test]. Gazeta.ru (June 6); Lemutkina, Marina. (2006). Rosobrnadzoru propalili obshak [Rosobrnadzor lost its sources of illegal income]. Gazeta.ru (September 25); Lemutkina, Marina. (2007). Rosobrvygovor [Rosobrreprimand]. Gazeta.ru (April 9).

${ }^{13}$ See, for instance, Desruisseaux, P. (1999). Cheating is reaching epidemic proportions worldwide, researchers say. The Chronicle of Higher Education, (April 30), p. A45; Wilgoren, J. (2000). Cheating on statewide tests is reported in Massachusetts. The New York Times, (February 25); Baty, P. (2004). Survey shows cheating is rife. The Times Higher Education Supplement, (July 2); Henry, J. 2001. More heads found guilty of tests cheating. The Times Higher Education Supplement, (October 8); Reznik, I. (2004). Vzroslye vrut, shkol'niki spisyvajut [Adults lie, students cheat]. Gazeta.ru (March 23). 
faculty in scholarly writing and research. ${ }^{14}$

Ethics misconduct, including sexual misconduct, is not related directly to academic process and is not confined to higher education institutions only, but can be found in other organizations as well. The issue of sexual misconduct in academia is not paid much attention in the media, except The Chronicle of Higher Education in the US.

Another phenomenon that can hardly be found in any reports by the selected media sources is an abuse of public property, despite the fact that many public higher education institutions in the US, the UK, and the RF own and manage large academic facilities, numerous other premises, and land. There is only one report in Newsru that presents a groom picture of spaces in student dormitories being leased to private businesses, immigrants, and even illegal aliens, while out-of-town students, entitled to free housing, are denied accommodations in these dormitories for the lack of space. Money received from businesses is perceived to be filling pockets of college administrators, including those responsible for student housing. The situation may be typical for state higher education institutions in Russia, located in large cities, where cost of renting is increasingly high and demand for square footage is growing.

Breach of contract is a more serious phenomenon of corruption than is normally considered. The number of students in the class, lecture time, faculty-to-student ratio,

${ }^{14}$ US and UK sources were quick on accusing even the Russian President Vladimir Putin of plagiarism. Specifically, they commented on plagiarism in President Putin's doctoral dissertation based on the findings of an American researcher. The Russian sources, including Newsru, picked up these reports and placed them in their news for several weeks. See, for instance, Sunday Times: kandidatskaja dissertatsija Putina - plageat [Sunday Times: PhD dissertation of Putin - plagiarism]. Newsru (March 26, 2006); and Amerikanskie uchenye obvinili Putina v plagiate. Eto mozhet povlech' massovuju proverku dissertatsij rossijskih chinovnikov [American scholars accused Putin in plagiarism. This may lead to a massive campaign of checking quality of doctoral dissertations defended by Russian bureaucrats]. Newsru (March 27, 2006). 
quality of libraries, laboratories, and other facilities and equipment, and accessibility of faculty are all points over which fraud may occur. Unclear rules and conditions of educational contract leave enough room for abuse and allow for corruption in academia. This aspect of the academic process is either left unattended or is not referred to as corruption by the media. Some reports on quality of education and scandals around it may be found in the Russian media, including the conflict between students and the Department of Sociology in Moscow State University ${ }^{15}$ The media cares about credentials, when individuals buy fake degrees, but it cares little for breach of contract, when universities supply educational services below the announced quality.

Means used in corrupt activities to achieve certain goals include bribes, kinship, personal connections, reciprocity, and fraud. Bribes can be monetary and non-monetary, including durable goods and non-durable goods, services, and sex. Kickbacks as a form of delayed bribes can include direct payments, tuition waivers, registration fees, trips, vacations, services, gifts, office supplies and equipment. Often kickbacks are calculated as a percentage of the total contract value. Kinship includes relatives' discretion, access, and ability to influence decisions. Personal connections are good relations with people who are in a position of discretion, access, or ability to influence decisions. Reciprocity means exchange of favors. Means of fraud are fraudulent documents, including IDs, bank statements, and fraudulent claims.

Locus or areas and processes in higher education that become corrupted or are susceptible to corruption include access to higher education, academic process,

${ }^{15}$ Obshestvennaya palata prokontroliruet situaciju na sotsfake MGU [Obshestvennaja Palata will take under control the situation in the Faculty of Sociology in MGU]. Gazeta.ru 2007 (April 21). 
graduation, credentials, licensing and accreditation, funding, faculty hiring and promotion, research, grants, and healthcare.

Corruption in access to higher education occurs or is connected to: standardized tests, regarded in lieu of the entry examinations; admission decisions, made by the members of admission committees and/or admissions offices; entry examinations, administered by the universities; sponsorship, donations, gifts, and contributions, including anonymous ones. In the US, donations are not reported as possible bribes in exchange for admissions to prestigious universities, simply because this is "the way the system works." Fundraising, a recent trend in some British universities, is now discussed in the media, but is not associated with possible corruption in admissions. The same is characteristic of Russian higher education institutions. President of Moscow State University (MGU) Victor Sadovnichy reports that some new buildings on the University's campus were built thanks to generous donations of corporate sponsors. Sadovnichy also prizes himself for managing to triple faculty's salaries thanks to external sources of income. ${ }^{16}$

Corruption in the academic process occurs with unfair or biased assignment of positive and negative grades; unequal initial conditions for students, including additional time for test for $\mathrm{ADD}^{17}$ students, whose special needs are based on false or incorrect medical diagnoses; time spent on a student as a client or consumer of educational services, including office hours and consultations not held by professors.

Forms of corruption in graduation include gifts, graduation by petitioning, and

${ }^{16}$ Sprosite Viktora Sadovnichego. On-line interv'ju rektora MGU Viktora Sadovnichego [Ask Victor Sadovnichy. On-line interview with the rector of MGU Victor Sadovnichy]. Gazeta.ru (May 6, 2007).

17 Attention deficit disorder 
organization of banquets by matriculating students for their professors. As follows from works of Rait (1931), Rashdall (1936) and Thelin (1982), these forms of corruption come from medieval universities and remain largely unchanged. They are considered quite innocent and are not paid much attention by the media.

Corruption linked to academic credentials includes provision of educational credentials, diplomas, transcripts, certificates, and other related documents by diploma mills; transfer of educational credits from a lower-quality institution or a diploma mill to a higher-quality or higher-ranked institution; production, sale, and usage of fake diplomas that reproduce diplomas and other educational documents of accredited and commonly recognized universities. Diploma mills were known to exist in the decentralized and loosely coordinated US higher education for decades. ${ }^{18}$ In the RF, diploma mills are almost non-existent even now. However, quality of educational programs in some private colleges is below the standards set by the government. Also, fake diplomas are reported to be sold on the streets. ${ }^{19}$

Licensing and accreditation are procedures of quality control that are vulnerable to corruption. Provision of services below established standards makes higher education institutions pay bribes to state or regional accreditation agencies in order to gain or maintain accreditation and continue to stay in the educational business. This is typical for the RF, where colleges with poor quality of instruction have one year to improve or to be

\footnotetext{
${ }^{18}$ See, for instance, Bartlett, T., and S. Smallwood. (2004). Inside the multimillion-dollar world of diploma mills. The Chronicle of Higher Education, 50(42) (June 25), p. A8.

${ }^{19}$ MacWilliams, B. (1999). Diplomas for sale on Moscow's streets: $\$ 800$ degrees from universities reflect the corruption of Russian higher education. The Chronicle of Higher Education, 16 (July 16).
} 
closed. ${ }^{20}$ The growing private sector in higher education shifts the media's attention from corruption in faculty-student relations to state-university relations. On the other hand, in the US, the government turns to the False Claims Act to encourage colleges to adhere to the proper teaching practices and provide quality educational services. ${ }^{21}$ Similar to Russia, diploma mills in the US pay bribes in order to gain accreditation. ${ }^{22}$ The government attempts to fight diploma mills ${ }^{23}$ while diploma mills defend their rights in the court of law. ${ }^{24}$ The Chronicle reports that "An unaccredited institution based in Wyoming is going to federal court to challenge an Oregon law that prohibits using a diploma-mill degree to get a job. Kennedy-Western University argued in a complaint filed in July in U.S. District Court in Portland, Ore., that the law violates the First Amendment rights of its alumni by not allowing them to claim their degrees on their resumes. ${ }^{.25}$ This self-proclaimed university is afraid of loosing its clientele due to the restrictions on using its worthless degrees. Problems of diploma mills and accreditation may also collide. ${ }^{26}$

Corruption in faculty hiring and promotion includes lack of objectivity in

${ }^{20}$ Holdsworth, N. (2004). 'Quality Police' Axe Poor Colleges. The Times Higher Education Supplement, 1627, (February 14), p. 12.

${ }^{21}$ Van Der Werf, M. (2006). Lawsuit U. The Chronicle of Higher Education, 52(48) (August 6), p. A23. Van Der Werf reports that instructors at Chapman University allege that the college encouraged early dismissals, and that as a result many students did not get the minimum classroom training required in several subjects. If the college admitted that it engaged in this practice, the suit says, it would have never been accredited, and never received millions of dollars in federal grants and student aid.

${ }^{22}$ Bartlett, T. (2006). Fake university paid bribes for credentials. The Chronicle of Higher Education, 52(30) (March 31), p. A14.

${ }^{23}$ Carnevale, D. (2004). Federal and state officials discuss cracking down on online diploma mills. The Chronicle of Higher Education, 50(23) (February 13), p. A32.

${ }^{24}$ Foster, A. (2003). Illinois professor shuts down his web site on 'diploma mills'. The Chronicle of Higher Education, 50(9) (October 24), p. A38.

${ }^{25}$ Diploma Mill Sues Over Diploma-Mill Law. The Chronicle of Higher Education, 51(2) (September 3, 2006), p. A14.

${ }^{26}$ Bartlett, T. (2004). Member of accrediting group has Ph.D. from 'notorious diploma mill'. The Chronicle of Higher Education, 50(30) (April 2), p. A29. 
recruitment, bribes, nepotism, exchange of favors, pass-over, and discrimination. This topic is one of the least discussed. For instance, practices of employing ghost instructors in order to appropriate their publicly funded salaries are not described in the media. Some materials may be found in The Times Higher Education Supplement, pointing to low transparency and outdated procedures in faculty hiring and promotion in Italy, Spain, and the UK.

Corruption in research includes research fraud. Research fraud is discussed by the US and UK media sources, with the focus on the links of university researchers and medical and pharmaceutical industry. The discussion is bound around conflict of interest, misreporting or not reporting unfavorable results, and biasness of interpretations. ${ }^{27}$

Corruption in grants that includes embezzlement does not draw the attention of the media. This may be explained in part by the fact that most of the grants in higher education are research grants and because of the nature of research activities it is difficult to calculate the precise cost of the work performed and time spent on the grant. This is characteristic of US and UK systems. In the RF, the government is just starting to allocate research grants to few leading universities, after a significant break during the transition. Research institutes exist separately from higher education institutions, and hence, possible embezzlement in research grants is not related to higher education.

Corruption in healthcare and medical services provided by university hospitals include reduced time to a patient, i.e. client or consumer of medical services, as well as billing for medical services not rendered to patients. In the RF such kind of corruption in higher education is non-existent since higher education institutions do not offer medical

${ }^{27}$ Mangan, K. (2003). Many medical professors who serve on review boards also have industry ties, study finds. The Chronicle of Higher Education, (August 14). 
services. In the US in many higher education institutions medical centers produce over half of the institution's revenue and the potential for abuse is significant. However, the media does not report on this aspect of corruption in higher education.

Interactions where corruption occurs include relations between state and university, business and university, faculty and students, faculty and administration, students and administration, and students and state. Corruption in state-university interactions includes misdeeds in funding, student financial aid, appropriation of federal and state grants, granting non-profit status, and taxation. Corruption in businessuniversity relations includes research with intentionally biased results, provision of private educational loans on doubtful grounds, and healthcare fraud.

Corrupt activities between faculty members and students include all kinds of bribes, misconduct, as well as underpaid and free services that come from students. Corruption in faculty-administration relations finds its expressions in unfair treatment, promotions, and dismissals. The major form of corruption in students-administration relations is breach of contract, when the university administration fails to deliver quality educational services as abided by the contract. Finally, corruption in relations of state and students include financial aid fraud, when students defraud the government on their ability to pay, and legal status, when students use educational programs to gain and maintain their alien status in the country.

Rarely do media sources comment on such potentially corruptible practices as honoraria for invited speakers, who may also be key figures in allocating state funding and grants, making appointments to public offices, and having discretionary power over other important decisions. Here honoraria may play a role of a perfectly legal bribe. Such 
practices may constitute conflict of interest. Conflict of interest is highlighted, for instance, in the investigation of student loans in the US, where financial aid officers encourage students to borrow from certain preferred lenders, or in the discussions over potentially corrupt private tutoring services in the RF, where faculty members who sit on the admissions committees are also employed as private tutors for prospective students. At the same time the term of white collar crime is not used or applied in considering corruption in academia.

There are reports on cases in higher education that at first appear to be clear cases of corruption but can hardly fall into any of the established categories and can not be categorized as cases of corruption. For instance, The Chronicle of Higher Education reports on the decision of New York University to return money received as a donation, because the donor is being accused of bank fraud. ${ }^{28}$ Accordingly, the nature of the money is not clear and may well be criminal. However, this case does not imply corruption on the side of the University, especially since it made an ethically correct decision to return the donation.

Few other examples may be found in Newsu and include reports on an MGU student who owned and managed a brothel in Moscow and a group of ten individuals using a chemistry laboratory in MGU to produce illegal drugs. Neither of these cases can be classified as corruption in higher education, unless, for instance, as is in the latter case, it would be proven that the university administration was renting the laboratory to the

28 "We said from the time that the Yalincak family's legal issues became public that if the money was not theirs to give, that if it was ill gotten in some way, then the university would return it," said John Beckman, a spokesman for NYU. Leubsdorf, B. (2006). NYU seeks to return 1.25-million gift. The Chronicle of Higher Education, 52 (June 16), p. A28. 
drug producers without proper control over their activities, and furthermore, bribes or kickbacks were paid. Similar information comes from the Minister of Science and Education, who suggests testing all of the students, who's study is paid for by the state, for drug abuse. While pointing to a potentially large problem with usage of illegal drugs by students, this information does not relate directly to corruption in higher education.

\section{Comparing the findings by country}

As follows from media reports, some forms of corruption are region-specific while others are universal. Types of corruption are connected to the characteristics of the national systems of higher education (private, public, state). The general trend in the media is to reflect the growing concern about corruption in academia. In the US, more attention is now paid to fraud, plagiarism and cheating, while in the RF bribery in admissions and degree completion are in focus. The growing market of private educational loans in the US, which has increased tenfold over the last decade, rising from $\$ 1.7$ billion to $\$ 17$ billion, leads to different types of fraud in state-university relations. Fraudulent activities, in their turn, necessitate state and federal investigations.

In the RF, where educational loans, both private and state, are in their infancy and legislation is not detailed, this kind of fraud is virtually non-existent. At the same time, the traditionally corrupt admissions process receives the lion's share of the media's attention. The admissions decisions are made by faculty and are often corrupt. Half of all the places in public higher education institutions are funded by the state, which creates enormous pressure on faculty and raises the stakes as well as incentives for corrupt 
activities.

Access to higher education, expressed in terms of admission policies, is both restricted and broadened by corruption. Aspects of corruption in access to higher education discussed in the media in the RF and in the US are as follows. In the RF, students try to gain admission to a college. If they do it by illegal means, they defraud the university. There is no need to pay tuition in the governmentally funded programs, so the stakes are high. The measures to oppose prospective students defrauding the system include governmental control exercised through higher education institutions and law enforcement agencies.

In the US media, corruption in access to higher education is not discussed directly. However, there is a room for corruption in admissions and some of the corrupt actions are discussed without using terms "corruption" or "fraud." In the US, a large number of private universities, and especially fast growing private for-profit educational corporations, try to enroll students in their educational programs. One may find many cases when such higher education institutions defraud students in order to enroll them in the program or "to get them on board." The stake for the universities here is clearstudents' tuition that often comes from federal, state, and private educational loans and grants. There are several mechanisms in place to prevent such a fraud, including accreditation procedures by the regional accreditation boards and an oversight by the Department of Education. However, these are either voluntary or incomplete.

Presumably, fraud takes place when: first, a prospective student is convinced by the university administrators, including admissions officers, that he can be successful in the program, while his previous academic records point to the opposite. For instance, a 
prospective student is offered to enroll in a college program without having a high school diploma, or to complete "an accredited MBA program" without holding a Baccalaureate. Here a prospective student is defrauded. Simply put, a consumer is offered a product he cannot consume. The college files for financial aid for the admitted student. The student starts accumulating financial debt on his educational loans. When he drops out of college because of unsatisfactory academic performance, he carries financial debt. Second, when student leaves, the college continues to collect financial aid from the government. In essence, money is streamlined from the student to a higher education institution in form of tuition and fees. The money comes from governmental and private sources. This constitutes fraud on the side of the higher education institution. The essence of this type of fraud is in the following: the government offers loans not to everyone, but to those capable to be successful in the college; the government only offers financial aid to enrolled students.

The missing link is private banks that provide educational loans. Providers of student loans compete for clients and try to maximize their profit by monopolizing the market. Collusion of banks with higher education institutions becomes almost inevitable. Such collusion would be inevitable even without monopolization of the educational loans market. The latest developments and investigations by the Attorney General of the State of New York confirm this. Private banks may even establish their own for-profit colleges through which they will issue and collect educational loans. This scheme will allow increasing the number of the customers. Repayment of educational loans is enforced by the law, i.e. banks are backed by the state. This provides guarantees to the banks-lenders. The risks of failures to refinance will be compensated for by the higher interest rates. 
Quite possibly, educational loans industry will be the next largest industry after the home loans and mortgages. The principal distinction is that in the case of home loans, home is a collateral, while in the case of educational loans, education can hardly play the role of collateral, since human capital is by definition indivisible from an individual.

According to news reports, corruption in admissions exists in both the RF and the US, but seems to be working in the opposite directions. While in the RF prospective students pave their way to a higher education institution with the help of bribes, in the US corrupt activities are oftentimes initiated from the side of a higher education institution that tries to attract students. Corruption in admissions takes place in the UK as well. Technical difficulties and numerous reported violations in the national standardized test lead to a biased picture of scholastic abilities of prospective students, and hence, to unfair or altered chances of entering higher education. ${ }^{29}$

Individual corruption in the US is generally restricted to research fraud and, though to a lesser extent, conflict of interest and sexual misconduct. In the UK, the major discussion of different aspects of institutional and individual forms of corruption is concentrated around the ongoing reform that targets the funding of higher education. Other issues include the credibility of the results of national examinations that affect admissions decisions and the research ethics.

In the RF, institutional corruption is discussed along with individual corruption or otherwise is not paid much attention. Major focus here is on bribery in admissions, academic process, graduation, as well as on the availability of diplomas for sale. Recent

${ }^{29}$ See, for instance, Owen, G., \& Peek, L. (2001). Time cheats pass exams on the Net. The Times, (June 2); Wachira, K. (1999). Entrance exam helps foil cheats. The Times Higher Education Supplement, (September 10); Williams, H. (2001). Real lives: marked for life. So students bought stolen A-level papers. The Guardian, (June 15), p. 6. 
introduction of the national test and test-based admission decisions brings to fore issues of credibility of the test results and makes the discussion of access and equity more vivid.

There are certain aspects of corruption in each media source which are omitted. We think that omitted issues are country-related but not country-specific. For instance, in the US the discussion of institutional corruption misses the problem of diploma mills. This might be explained by the fact that the state does not guarantee quality of the degrees or the diplomas. Interestingly, the issue of diploma mills was given more attention in 1980s, when the federal government had conducted a series of investigations. Within the realm of individual corruption in US colleges, the missing aspects include bribery, possibly because there is not much of it in the faculty-student relations. In addition, many higher education institutions allow gifts for faculty members and staff as long as they do not represent conflict of interest.

As opposed to the US, media sources in the RF do not reflect on such an aspect of institutional corruption as fraudulent practices in athletics. This may be explained by the fact that intercollegiate athletics is not a big business in the country and in the region. Also, medical services and healthcare fraud in university hospitals are absent simply because higher education institutions do not render medical services. In the discussion of individual corruption, missing aspects include research fraud, because most of the research is done outside the nation's higher education institutions, within the Academy of Sciences (RAN); the leading universities are only involved in fundamental research where fraud is less common.

There is a difference in scope — national or international — of reporting on corruption in higher education by specialized and non-specialized editions in each of 
three countries. In the US, the specialized source comments on corruption in higher education internationally, while the non-specialized source comments nationally. The same is characteristic for UK sources. In the RF, the specialized edition comments nationally, while the non-specialized source comments internationally. The following explanation may be offered in this regard. The specialized sources in the US and the UK, i.e. The Chronicle of Higher Education and the Times Higher Education Supplement, respectively, focus exclusively on higher education, having their professional staff report on the problems of the industry. As globalization and internationalization of higher education develop, reports on higher education worldwide become necessary. At the same time, the leading nationwide news editions, including The New York Times and The Guardian, address mostly national higher education, as they reach out to the national reader. Here in-depth coverage of particular issues in higher education, especially in international and comparative perspectives, appears unnecessary.

In the RF, the situation is a bit different. The quasi-specialized edition Gazeta.ru has but a special section devoted to education, and higher education in particular, along with several other sections. This may explain the lack of in-depth investigations or extended analytical reports. The reports are dedicated to domestic problems, omitting the issues of higher education in other countries. The specialized educational edition Uchitel'skaya Gazeta ${ }^{30}$ is focused entirely on the issues of secondary education, and hence is not included in the analysis. Analytical work may be found in few newly established journals with the focus on higher education, but these are scholarly publications. In a different way from Gazeta.ru, the major news media source Newsru

\footnotetext{
${ }^{30}$ The Teachers' Newspaper.
} 
comments internationally. The secret is that this news edition often reprints brief informative reports that appear in the foreign media. The authorized reprints with proper on-line referencing are selected based on the promise of attracting the reader. These include reports on corruption in higher education worldwide.

Forms of corruption in higher education in the US emphasize state-university relations. Fraud is oftentimes the product of the grey area in the legislation. At the same time issues of fraud are relatively easy to move to court since the government is involved and the state interests are at stake. Traditionally, in the US many issues are decided through the judiciary branch of the government. Accordingly, the media reports on the specific legal cases, withstanding from making generalizations.

In the RF, where judiciary branch is relatively weak, most attention is paid to unfair admissions to governmentally funded places in public higher education institutions and bribery in academic process, because these are the most obvious forms of corruption. Bribes are presumed to have monetary form, which is traditionally least acceptable and not well-tolerated by the society. At the same time nepotism and cronyism are often overlooked, while these forms of corruption might have more presence in higher education and more impact on the admissions policy, than bribes.

Cheating among students is given attention equally by the media in all three nations. The US and the UK sources are more concerned with plagiarism than their counterparts in the RF. Fraud and embezzlement in research grants is a new topic in Russian media, while in the US it was in focus for a few years. Problems of corruption in licensing and accreditation are characteristic of both the US and the RF. In the US, accreditation is still a voluntary process and the US Department of Education is 
attempting to claim a higher authority in this realm. In the RF, issues of stateadministered obligatory licensing and accreditation are of high importance due to the development of private sector in higher education. Corruption in business-university relations, including pharmaceutical and high-tech industries, is mostly reflected in the US sources.

In The Chronicle of Higher Education, the word corruption is applied almost exclusively to international educational practices. US media sources are very cautious about using explicit terminology as applied to the domestic problems in education, avoiding words corruption, bribery, and fraud. For instance, the topic of research fraud may be found in only one or two publications a year, while research misconduct may be seen in around five to ten publications a year. Corruption and fraud are routinely replaced with the terms misconduct and breach of integrity. At the same time reports on fraud related to cheating and plagiarism are plentiful. Areas of access and accreditation are left almost unattended. The issue of accreditation, voluntary in the US, does not pair with abuse, bribery, fraud, corruption, scandal, or scam. The same is true for admissions to colleges.

As compared to the other media sources studied in this chapter, The Chronicle of Higher Education is the richest and most comprehensive source of information about higher education, with the largest scope of problems and issues highlighted in its reports.

Similar to the US sources, in The Times Higher Education Supplement the term bribery is only applied to foreign higher education. Bribery is reported in Kyrgyzstan, India, Nigeria, Russia, Venezuela, Vietnam, Ukraine, and some other countries and is not 
observed in the European Union countries, Canada, or the US. ${ }^{31}$ Most of the bribery in developing and transition economies is found in admissions to higher education. A certain political agenda can be traced through the publications. In Russia, bribes in admissions are reported, apparently based on the fact that the nation is in the process of introducing the standardized test that would replace entry examinations. Also, at least half of all the college places are funded by the government. In Belarus, according to The Times Higher Education Supplement's reports, antigovernment protests by the students and educators, including dissidents, are most popular, pointing to the authoritarian political regime. ${ }^{32}$ The problem of diploma mills is related to the US, as Britain has its stakes in both issues of free trade and in accreditation. In China, fake educational certificates are in the focus. ${ }^{33}$ This may be explained by the large population and intensive migration, including into the US and the European Union.

${ }^{31}$ See, for instance, Holdsworth, N. (2006). Minister: Blow The Whistle On Bribes. The Times Higher Education Supplement, 1573 (January 24), p. 17; Orozco, J. (2006). Access plans have yet to show results. The Times Higher Education Supplement, 1767 (November 2), p. 11; Hayton, B. (2006). Rug pulled from under cheats. The Times Higher Education Supplement, 1752 (July 21), p. 10; Rich, V. (2006). Passing Exams Is A Real Gift. The Times Higher Education Supplement, 1730 (February 17), p. 13; Raghavendra, V. (2006). Indian Exam Racket. The Times Higher Education Supplement, 1729 (February 13), p. 13.

${ }^{32}$ The Times reports that detained Belarusian scientist Yury Bandazheuski, former rector of Gomel Medical University and an Amnesty International "prisoner of conscience", has been released on parole. He became eligible for parole earlier this year, having served two thirds of his eight-year sentence, but his application was denied, seemingly because he refused to admit to the charges against him. Professor Bandazheuski was convicted of taking bribes from university entrance candidates. Bandazheuski said that the charges of bribery were politically motivated and that his real "offence" was his research on the long-term medical consequences of the 1986 Chernobyl nuclear accident. Rich, V. (2005). Jailed Scientist Granted Parole. The Times Higher Education Supplement, 1707 (September 3), p. 10.

${ }^{33}$ See, for instance, Maslen, G. (2005). Trade In Fake Papers Soars. The Times Higher Education Supplement, 1694 (June 7), p. 12. 
Problems of quality control and licensing were reported for Russia as well. ${ }^{34}$ This may be explained by the fact that Russian higher education is still characterized by the high level of centralization and control. Nepotism is being reported in colleges in Italy, Spain, and the UK, as related to faculty hiring and promotion and student enrollment and retention. There are plenty of reports on fraud in higher education, including research fraud, cheating, plagiarism, and embezzlement. These reports, presented in The Times, highlight fraud in the UK, the US, and other countries. It appears from the British media sources, that most represented forms of corruption in the country's educational system are cheating, plagiarism, and gift-giving.

In general, level of comprehensiveness of the reports on corruption in higher education that may be found in The Times Higher Education Supplement is not as high as that in The Chronicle of Higher Education.

The media reflects on three different systems with different access policies. US sources report corruption in higher education in the RF based on the information obtained from the Russian news sources, without specifying that education is free for over half of all students and that public funding of colleges is one of the fundamental grounds for corruption in admissions to exist. At the same time, US sources do not mention the widespread practice of private donations, gifts, and charitable contributions to universities that exist in the nation. Such practices are considered a norm, as they were at the very core of establishing higher education institutions and are not challenged as doubtful even now.

Russian sources do not specify anything about the US higher education, with the

${ }^{34}$ See, for instance, Holdsworth, N. (2004). 'Quality Police' Axe Poor Colleges. The Times Higher Education Supplement, 1627 (February 14), p. 12. 
information presented in the reports being very limited, partial, and highlighting major news points. Such partiality allows for taking reported cases of corruption out of the context. The analysis of different forms of corruption in the US higher education is absent. In the RF, when institutional corruption is mentioned, it is always paired with individual corruption. This contrasts with the US, because it tends to focus on institutional corruption.

In the UK, where virtually all higher education is public and stakes of being admitted to a higher education institution are high, corruption in admissions is not reported, except for cheating, irregularities, and technical failures in the national test. This seems to be doubtful at first, because the cost of education is much higher than the recently increased fees. Nevertheless, it is possible, if one is to take into account a sufficient number of places in colleges to satisfy public demand and the role of the standardized test score as the only criterion in admissions decisions.

Trends in time in each category more or less reflect the trends in the higher education industry. Private educational loans in the US, education fees in the UK, and standardized examinations in the RF are all in the news along with cases of corruption that accompany these changes and reforms. In general, more attention is paid to different aspects of corruption in the media now than it was at the beginning of the study period. The dynamics of reporting different aspects of corruption in the media are presented in Figures 1 to $5 .{ }^{35}$

${ }^{35}$ The data for 2007 were prorated at 1.33 , since the real data analyzed for this year are for the period of January 1, 2007 to September 30, 2007. This was made under the assumption that the media reports are not season-related but smoothly distributed along the one-year period. 


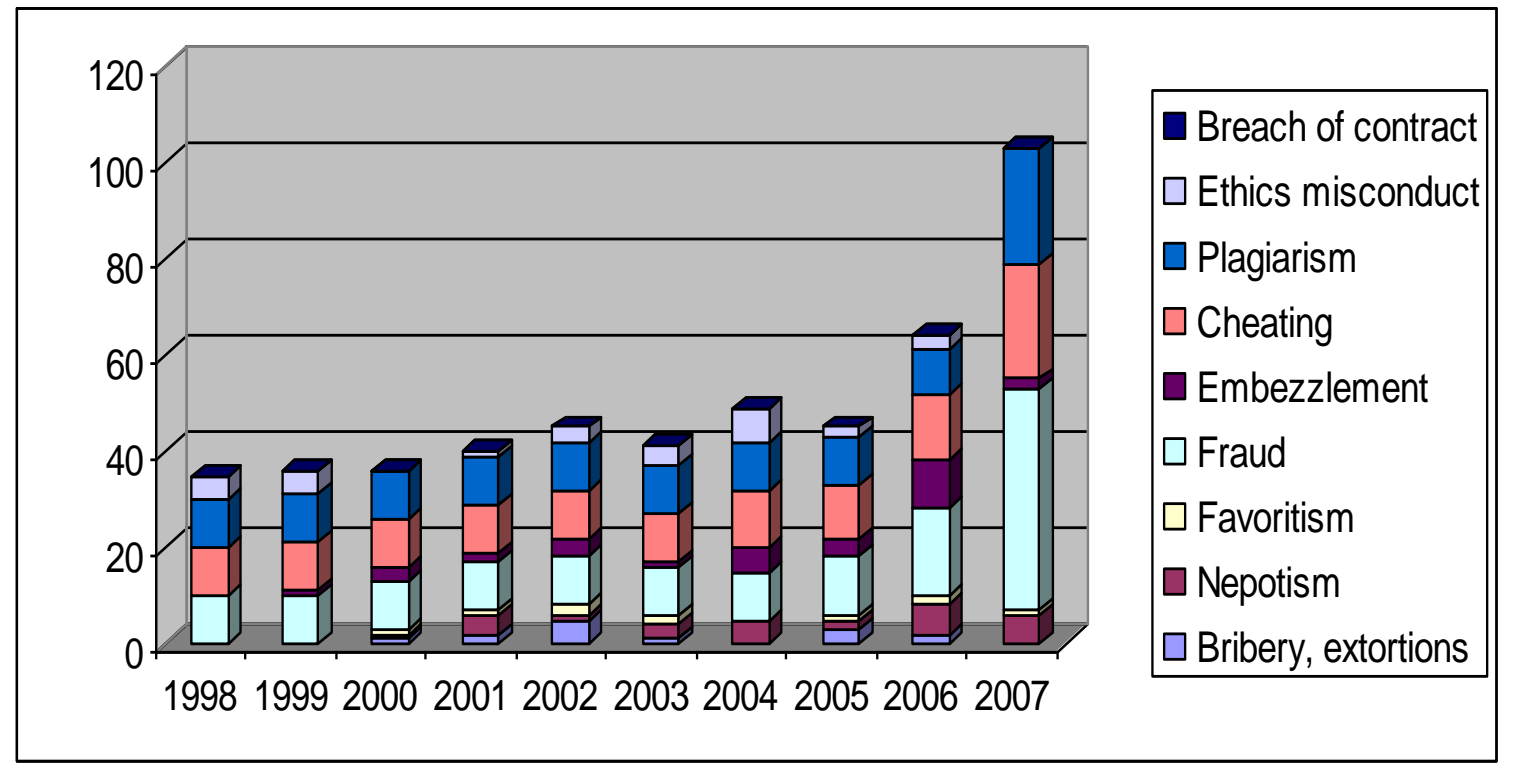

Figure 1. Dynamics of The Chronicle of Higher Education reports on corruption in higher education by phenomenon, 1998-2007

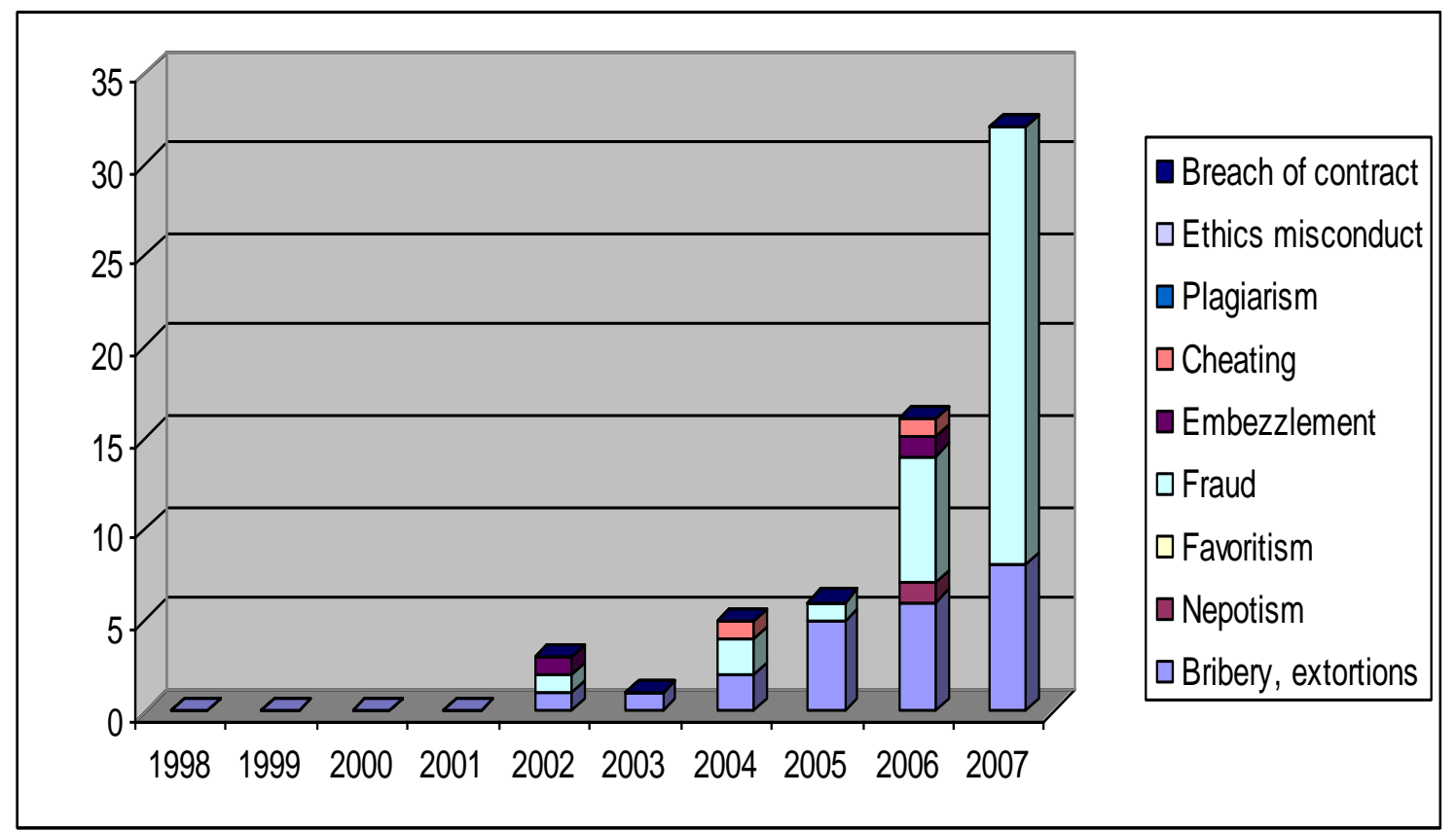

Figure 2. Dynamics of Gazeta.ru reports on corruption in higher education by phenomenon, 1998-2007 


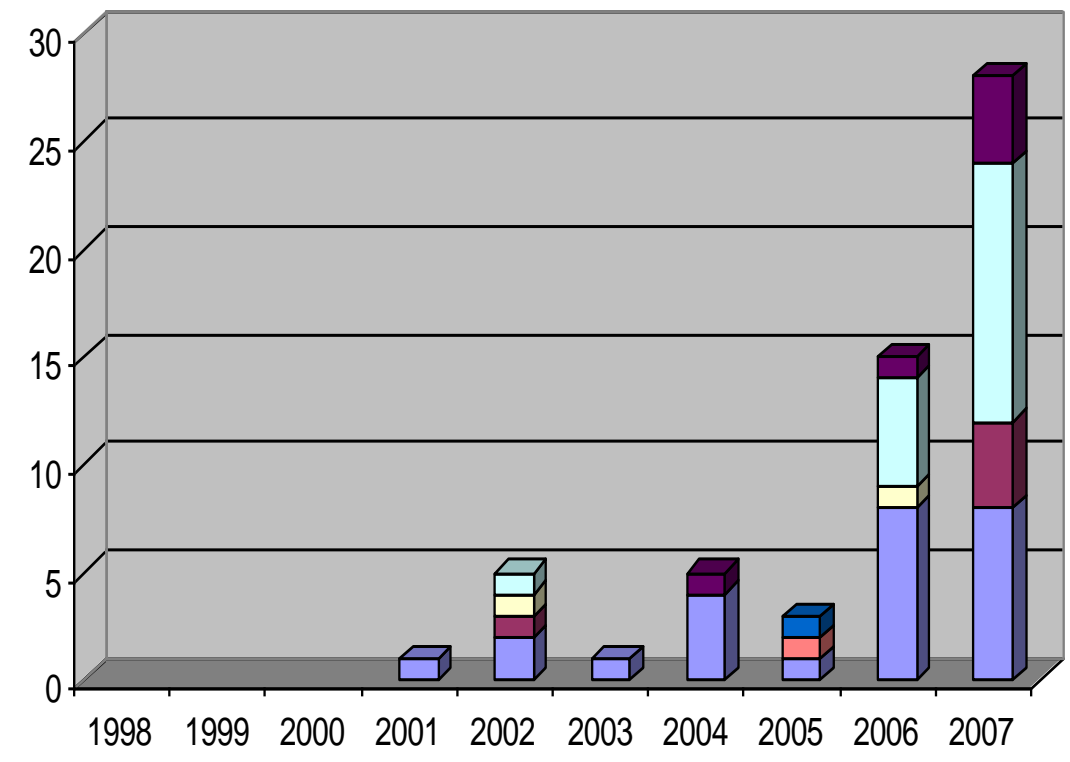

Breach of contract

$\square$ Ethics misconduct

口Plagiarism

$\square$ Cheating

$\square$ Embezzlement

$\square$ Fraud

$\square$ Favoritism

$\square$ Nepotism

$\square$ Bribery, extortions

Figure 3. Dynamics of Newsru reports on corruption in higher education by phenomenon, 1998-2007

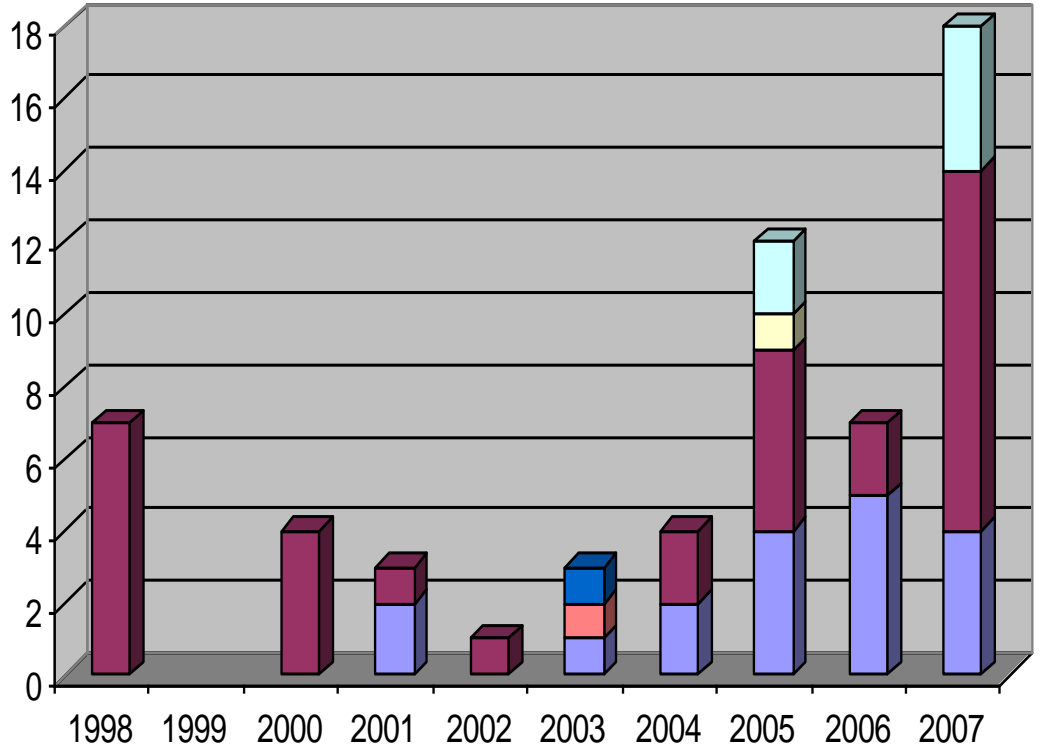

Breach of contract $\square$ Ethics misconduct

$\square$ Plagiarism $\square$ Cheating Embezzlement $\square$ Fraud 口Favoritism 口 Nepotism $\square$ Bribery, extortions

Figure 4. Dynamics of The Times Higher Education Supplement reports on corruption in higher education by phenomenon, 1998-2007 


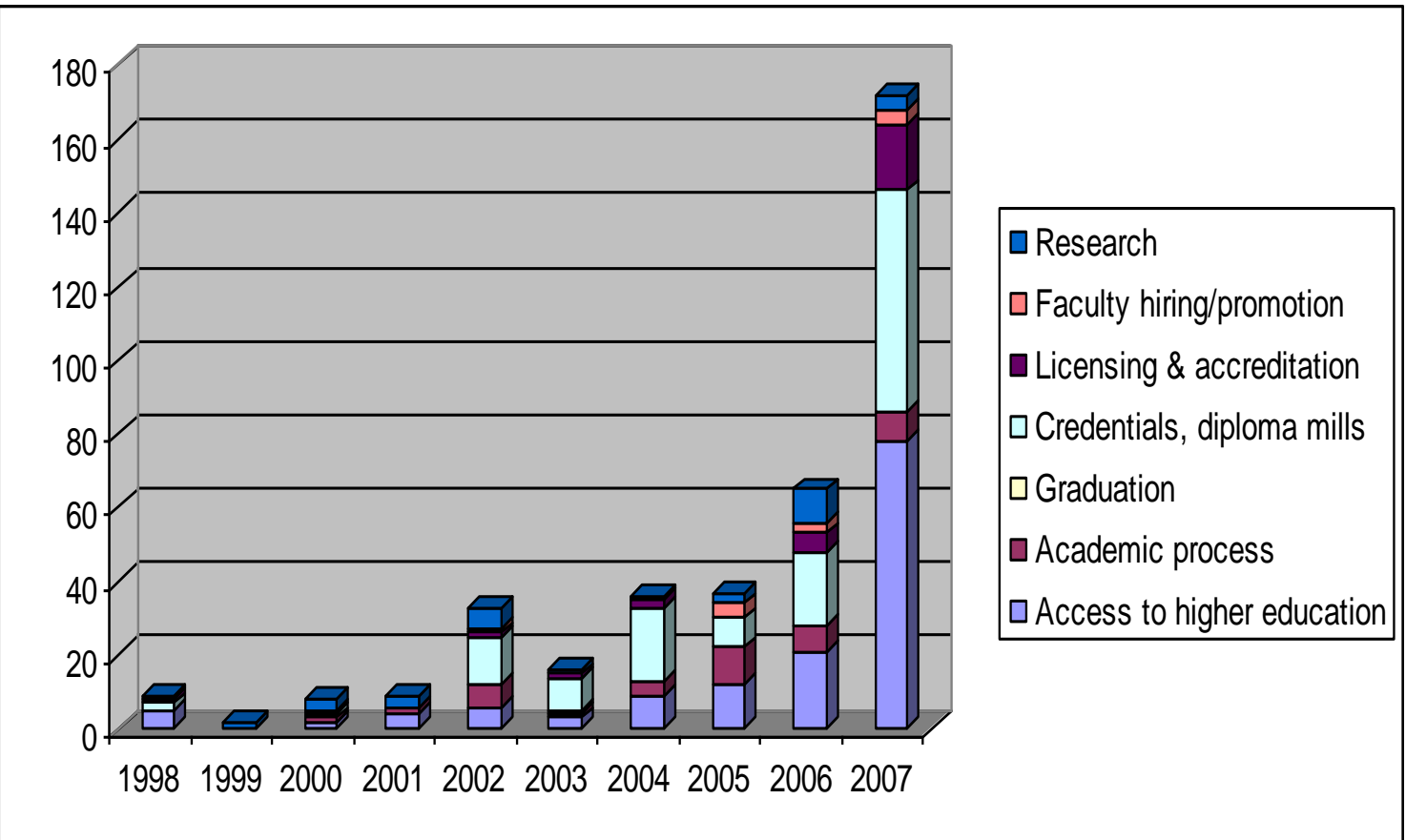

Figure 5. Dynamics of media reports on corruption in higher education by locus, 1998-2007

The Chronicle of Higher Education pays most attention to such phenomena as fraud, cheating, plagiarism, and embezzlement, with fraud being on the rise thanks, first of all, to the series of investigations lead by Mr. Cuomo. Among means of corruption, fraud is the leading type for the US, while bribes are most common means of corruption overseas. According to the source, most instances of corruption may be found in stateuniversity and student-university relations. The issue of educational credentials fraud and diploma mills appears to be regaining popularity, especially in 2002, 2003, 2004, and 2007. In line with The Chronicle of Higher Education, The New York Times focuses on fraud as both a phenomenon and a mean of corruption, and on educational credentials.

The Times Higher Education Supplement reports mostly cheating and nepotism domestically and bribery and nepotism internationally, both being connected to the issue of access to higher education. Many other areas where corruption may potentially exist 
are left unattended. The Guardian points to cheating, plagiarism, and fraud, in academic process, research, and access to higher education. The number of reports over the last decade appears to be minimal.

Gazeta.ru pays most attention to bribery, extortion, and fraud that takes place in academia, and may be found in admissions to higher education institutions, in academic process, in issuing educational credentials, and in licensing and accreditation.

Accordingly, most of corruption is found in interactions between faculty and students and state and universities. The newspaper also publishes letters from the readers, including ones focused on different aspects of corruption in higher education. Newsru publishes news about corruption in higher education that mostly contains bribery in admissions. A more recent trend is discussing fraud linked to educational credentials and licensing and accreditation. Similar to Gazeta.ru, Newsru reflects on corruption in faculty-students and state-university relations. Increasing awareness of the public about the credentials fraud indicates that the public finally came to understanding that knowledge is of value, not certificates.

The differences between media reports are not language-specific, i.e. Englishlanguage media in the US and in the UK reflect on the country-specific aspects of corruption. The same is true for the Russian-language sources in the RF.

It is difficult to establish a strong positive correlation between the media coverage of corruption in higher education in each of the three countries and the level of corruption perceived to be characteristic for the society. According to the Corruption Perceptions Index (CPI), in 2006, the RF was in $121^{\text {st }}$ place with the score of 2.5 , and the US at $20^{\text {th }}$ position with the corruption score of 7.3. The UK was least corrupt, occupying the $11^{\text {th }}$ 
position..$^{36}$ The statistical data on corruption in higher education in the US and in the UK could not be found. The RF is quite unique in this sense. The scope and major forms of corruption in higher education reflected in the media correlate with the results of polls and surveys on corruption, including those conducted by the INDEM foundation. ${ }^{37}$ The data presented by INDEM indicate an increase in corruption in higher education for the period of 2001 to 2005 .

\section{Conclusion}

Corruption in higher education receives good coverage in the media. The level of transparency is high enough to highlight the issue, its significance, scale and scope, and variety of forms in which it manifests itself, and inform the general public of its prevalence, patterns, and forms. However, the positive effect of such a high level of transparency and open discussion in the media on the level of corruption in higher education has yet to be seen.

Corruption in higher education, and the way it is reflected in the media, appears to be consistent with trajectory and pace of reforms that take place in higher education industry in the US, the UK, and the RF. Introduction of college fees in the UK, reduction of governmentally funded places in the RF, and the growing significance of private educational loans in the US, all lead to an increase of corruption in access to higher

\footnotetext{
${ }^{36}$ Transparency International 2006. Corruption Perceptions Index. Retrieved from http://www.transparency.org/policy_research/surveys_indices/cpi

${ }^{37}$ See Satarov, Georgy. (2006). Corruption Process in Russia: Level, Structure, Trends. In G. Satarov (Ed.). Diagnostics of Corruption in Russia: 2001-2005. INDEM Foundation. Retrieved from http://www.indem.ru/en/publicat/2005diag_engV.htm
} 
education.

The continuing massification of higher education with increasing enrollment rates in all three countries, as well as the emergence of for-profit sector, necessitate more control and coordination on the side of the government, educational institutions, and the public. Growing concerns over the quality of educational services lead to an increase in reporting bribery, fraud, cheating, plagiarism, diploma mills, breach of contract, and other forms of misconduct. The processes of internationalization and globalization of higher education put an emphasis on such aspects of corruption as credentials fraud and research fraud.

Socio-economic context of educational reforms and changes in each country leaves its print on major forms of corruption in higher education. For instance, in the RF, economic transition and sharp decline in salaries of college faculty lead to an increase in bribery and nepotism. In the US, growing competition between higher education institutions leads to an increase in fraud associated with student financial aid.

Lastly, growing levels of transparency and information flow lead to a better understanding of different forms of corruption and its scope and scale. The media plays a primary role in highlighting the issue. However, media reports are focused on corruption per se, and often on its causes, but do not offer solutions or ways in which the public can resist corruption. 


\section{CHAPTER III}

\section{GREY AREAS IN HIGHER EDUCATION:}

\section{ILLEGALITY VERSUS CORRUPTION}

\section{Introduction}

Corruption in higher education has long been neglected as an area of research in the US. One reason for this might be that the relative scarcity of prosecuted cases has made it at first appearance not a large problem in the nation's higher education, not significant enough from the researchers' standpoint to be paid much attention. Another explanation for this is that the all of the scholars attended higher education institutions and most of them teach in colleges and universities. The sense of belonging and close affiliation may prevent from involving in research of academic corruption.

Also, scholars as well as the media are overly cautious about the language of investigations and usage of such explicit legal terms as corruption, bribery, fraud, replacing them with such terms as misconduct and breach of integrity. Finally, definition of education corruption itself is still vague and undeveloped. This creates uncertainty in the subject matter of the prospective research, approaches to be applied, and methodologies to be employed. The limits of the object of the research, i.e. the locus, also remain unclear for those who would want to venture to study corruption in higher education. The major task of this chapter is to address the question: How is corruption in higher education understood and defined in legal cases, what particular cases receive 
more attention, and how these cases correlate with the major educational reforms, changes, and socio-economic context in the nation? Specifically, it analyses records of selected legal cases devoted to corruption in higher education.

\section{Legality versus corruptibility}

It might be useful to start the endeavor of defining corruption in higher education with the legal definition of corruption as presented in the US federal laws. Similar to scholarly publications, in legislation most of the attention is paid to political corruption. ${ }^{1}$ In general, on the federal level, aside the political corruption, one may find more concerns with foreign corrupt practices than with domestic ones. These include The Foreign Corrupt Practices Act of 1977 (15 U.S.C. § 78dd-1, et seq.) The Foreign Corrupt Practices Act is a United States federal law known primarily for two of its main provisions, one that addresses accounting transparency requirements under the Securities Exchange Act of 1934, and another concerning bribery of foreign officials, and International anticorruption and good governance provisions. ${ }^{2}$ The Act was amended in 1998 by the International Anti-Bribery Act of 1998 which was designed to implement the anti-bribery conventions of the Organization for Economic Co-operation and

${ }^{1}$ See references to political corruption "Section 610 of the Federal Corrupt Practices Act makes it a crime for a corporation or a labor union to make a '...contribution or expenditure in connection with...' federal elections." Reference to United States vs. International Union of Automobile Workers, CIO, 352 US, 567, 575, (1957). Federal Corrupt Practices Act. Comments. Constitutionality of section 610 of the Federal Corrupt Practices Act. California Law Review, 4693), p. 439). The Federal Corrupt Practices Act $§ 602,18$. In United States Code Service: lawyers edition. General Index A-C, USCS. Bribery and graft, p. 879

${ }^{2}$ United States Code Service: Lawyers Edition. General Index A-C, USCS. 
Development (OECD). There are also Consumer and Borrower Protection regulations in the federal legislation, but they do not fill the gap between the legal regulations and a common sense understanding of corruption. This explains the presence of grey areas in the field of corruption that are left unattended. Different related laws may apply to different crimes or misdeeds, but precedents have to be made, corruptibility has to be established, and terminology has to be further developed.

The term most associated with corruption is bribery. Bribery signifies the phenomenon itself and the act of corruption, while bribe denotes the mean of exchange. USCS, when presents definition of corruption, primarily refers to Bribery and Graft section. ${ }^{3}$ Corruption is conventionally understood as indivisible from the public sector, requiring a public official to be a primary object of bribery.

According to $§ 201$ of the USCS, bribery of public officials and witnesses, the term "public official" means Member of Congress, delegate, or resident Commissioner, either before or after such official has qualified, or an officer or employee or person acting for or on behalf of the United States, or any department, agency or branch of Government thereof, including the District of Columbia, in any official function, under or by authority of any such department, agency, or branch of Government, or a juror. This also includes a "person who has been selected to be a public official."4

A corrupt public official "directly or indirectly, corruptly demands, seeks, receives, accepts, or agrees to receive or accept anything of value personally or for any

${ }^{3}$ United States Code Service: Lawyers Edition. General Index A-C, USCS. Bribery and Graft section, p. 578.

${ }^{4}$ United States Code Service: Lawyers Edition. Crimes and Criminal Procedures $\S \S 1-430$. Title 18 USCS. Chapter 11. Bribery, Graft, and Conflicts of Interest, pp. 278279. 
other person or entity in return for: (A) being influenced in his the performance of any official act; (B) being influenced to commit or aid in committing, or to collude in, or allow, any fraud, or make opportunity for the commission of any fraud, on the United States, or; (C) being induced to do or omit to do any act in violation of the official duty of such official or person." A corrupt public official is a recipient in a corrupt transaction. Donor, or bribe-giver, is "whoever directly or indirectly, corruptly gives offers, or promises anything of value to any public official..."6

The legal structure that operates in the realm of bribery and corruption appears to be over-simplistic--there are bribe givers and bribe receivers. However, complexities come in when particular legal cases are considered and judged on, especially those involving large organizations and systemic abuse of public office. There are too many nuances, such as "had authority," "did not have authority," "accepted without an intent to change his opinion," "gave gift without an intent to influence the discretion or change the decision," etc.

Broader conceptual understanding of corruption is needed. Legality and corruptibility may be dominating characteristics of a corrupt agreement. Corruptibility denotes possibilities for abuse and vulnerability of the system overall, while legality implies certain laws set by the public through the state or the ruling regime. The issue of legality versus corruptibility is appealing in the sense that it positions intents, possibilities, opportunities, mere expectations, and public trust against such specific terms as public office, size of a bribe, fact of bribery, etc.

\footnotetext{
${ }^{5}$ Ibid., p. 279.

${ }^{6}$ Ibid., p. 279.
} 
Arora (1993) singles out four perspectives on corruption, including legal, historico-cultural, public interest, and market-centered approaches. Hodgkinson (1997) notes that "According to Arora, the main advantage of adopting a legal perspective on corruption is that it '...enables an agreement over the definition and ... scope of its study' (1993:2). It therefore involves defining corruption in terms of behaviour which deviates from the legal norms of public office."

Hodgkinson (1997) presents a review of conceptual approaches to the issue of corruption, outlines primary and secondary corruption, and points to the weaknesses and possible pitfalls of marketisation in public services. Hodgkinson (1997, p. 18) suggests that "The attempt to model public service organizations on private enterprise is meant to align the former with a changed socio-economic environment. The basic premise being that the success of the private sector model can be replicated in the public services. Marketisation has therefore involved a movement from 'budgetary' to 'for-profit' organizations."

Legal perspective appears to be one of the accepted forms of approaching corruption. Arora (1993, p. 2) points out that legal perspective “...enables an agreement over the definition and ...the scope of its study." In addition to legal perspective, there might be numerous other perspectives employed, including historic, cultural, public interest, and market-centered perspective. Another approach anticipates possible conceptual frames based on legal, economic, social, moral, and ethical responsibilities.

As applied to higher education, a legal lens uses the set-out laws and regulations that project on complex processes occurring in the education sector in order to sort out legal and illegal ones. The economic responsibility anticipates compliance with mutually 
accepted economic obligations under which violations of such obligations are considered a breach of contract. Reduced class time, increased class size, absence of office hours held by faculty members, and unfavorable lending terms and conditions on educational loans may be considered a breach of contract. While not necessarily specified in laws and legal provisions for higher education, such practices may be interpreted as a violation of economic responsibility.

The social responsibility frame is even more complex than legal and economic responsibility frames. The social responsibility frame anticipates that higher education institution adheres to all legal and economic obligations and, in addition, performs its societal duties. Educational, research, cultural, and other considerations are taken into account. The social responsibility frame views higher education institution as an organization that conducts responsible research for the betterment of the society, educates members of the society in accordance with the best standards available, and disseminates knowledge to those who are in need of it. Monetary transactions and the financial prosperity of an institution of higher learning are secondary in such cases. This approach is also known as a better service for public good that increases total social welfare of the society.

Finally, the moral or ethical responsibility is meant to move higher education institution to prioritize the issue of equity over the issue of quality, and quality over access. If under the economic responsibility frame, a university sets its admission criteria and regulates quality of educational services offered based on demand and supply on the education market, ethical responsibility anticipates equality in access to education and the 
provision of highest quality educational services under the conditions of maximizing the position of learners and the society overall rather than of profit maximization.

While ethical, social, and economic frames are more universalistic, the legal responsibility frame is clearly nation-specific. On the one hand, economic structures in the education sector vary country by country and can be assigned to a few basic models; on the other hand, legal perspective can allow for some future perspective rather than simple comparisons. Experiences of other nations and comparative perspective as applied to higher education corruption are of little help. The US higher education system is unique in the way it is organized and funded.

The US higher education sector may be described as decentralized, marketoriented, and autonomous. Other developed nations, including the European Union, have centralized higher education sectors that may be characterized by weak links with businesses and slowly emerging market-like practices. Educational loans are not common in the developed nations. Hence, national legislations do not reflect such practices. The process of commoditization of higher education in the US continues, while in Europe it only emerges.

We consider corruption to be broader than it is defined in legal cases. At the same time we use the level of legal responsibility from the set of legal, economic, social, moral or ethical responsibilities to qualify deeds as corrupt. But even this approach does not cover all the areas. There are so-called grey areas that may be judged as corrupt yet still not illegal. Norms of contractual behavior accepted by the society go ahead of legislation. The series of investigations launched by the Attorney General of New York, Mr. Cuomo, is a classical example of grey area application. It leads to new, more precise, more 
specific, contextual interpretation of existing laws, and results in new provisions, regulations, and codes of conduct.

National laws differ and legality and illegality are not universal. Accordingly, there might be not one universal definition of corruption in higher education that would apply equally well to different national systems in different historical periods. Granting access to publicly funded higher education on any premise other than academic merit is equated to corruption. Access to higher education in exchange for a bribe is deemed to be corrupt. In the decentralized market-based systems of higher education, gaining access to educational services in exchange for payments is a norm. Depending on the system and legal frameworks laid in the society, certain forms of funding, modes of operation, patterns of behavior, and standards of conduct in higher education may be considered corrupt or non-corrupt. Corruption in higher education is time and place specific and may be found in public and private higher education institutions.

This chapter uses operational definition of corruption in higher education as a system of informal relations established to regulate unsanctioned access to material and nonmaterial assets through abuse of the office of public or corporate trust. In this sense, corruption in higher education anticipates abuse of public trust by certain participating groups or individuals-participants of educational process in a broad sense, and processes, closely related to educational process, such as research, selection of students, funding, use of public property etc. To summarize, this chapter considers corruption as it implies illegality or a precedent and at the same time does not limit its area of investigation by the legal definition of corruption only. 


\section{Corruption as a grey area}

A grey area is a term used to mark things that are unclearly defined, a border that is hard or even impossible to define, or a definition where the dividing line tends to shift. A grey area of definitions signifies a problem of sorting reality into clearly cut categories. A grey area in legal terms is an area where no clear legislation or precedent exists. It is also not clear whether the existing rules are applicable to specific cases and to what extent. A grey area of legislature as applied to particular industries, sectors, market segments, or areas of social life signifies an ethical dilemma, where the border between corrupt and non-corrupt activities is vague.

Shleifer and Vishny (1993) use the term "grey area" in addressing economics of corruption. Kaufmann and Vicente (2005, p.3) propose "a new explicitly micro-founded definition of corruption: it is viewed as a collusive agreement between a part of the agents of the economy who, as a consequence, are able to swap (over time; we present a repeated game) in terms of positions of power (i.e. are able to capture, together, the allocation process of the economy). This is the idea underlying high-level corruption or 'influence', and is broader than the notion of bribery, which corresponds to a particular sharing pattern of the joint payoff from the referred relationship."

The challenge to the domain of bribery in the issues of corruption, however, does not eliminate grey areas that exist in both legislation and scholarly work. Grey areas in legal scholarship and in economics project on legislation and the national economy, respectively, and overlap. Tax evasion and fraud as key characteristics of shadow or unofficial economy are good examples of such an overlap. 
Petrov and Temple (2004) comment that "we find unconvincing the proposition that there exists a continuum from 'honest' to 'corrupt' behaviour. Such a continuum implies a 'grey area'. The example given at a recent conference on corruption in education of such a 'grey area' was the practice of some US universities of giving the children of alumni preference in admission procedures. This example simply adds to our doubts about the 'continuum' notion: one may judge this to be an undesirable way of managing university admissions, but a stated institutional policy, presumably adopted with the intention of in some sense benefiting the institution as a whole, cannot, we suggest, sensibly be classified as corrupt."

Clearly, Petrov and Temple are against the notion of grey area. This chapter agrees with the notion of legality and illegality as applied to the problem of corruption, yet considers necessary to accept the fact that not all types of corrupt activities or forms of corruption are embedded in the national legislations. Furthermore, the legal lens is perfectly applicable to corruption in education, but not sufficient to understand and reflect on the complexity of the issue. The broad scope of the problem explains the vagueness of its borders.

The legal frame, however, has its limitations. In Hodgkinson's (1997, p. 19) view, "A legal perspective would negate the possibility of investigating a change in the nature of corruption." To substantiate this view, Hodgkinson refers to Arora (1993, p. 2), who points out that legal frame would not "....allow looking into actions or inactions which corruption laws do not cover, yet which need to be included. In fact, corruption laws and

${ }^{7}$ In their critique of the grey area notion, Petrov and Temple refer to Hallak, J., \& Poisson, M. (2002). Ethics and Corruption in Education. Results from the Expert Workshop held at the IIEP. Paris, November 2001. Paris: IIEP-UNESCO. 
gaps in these may themselves be an object of corruption in some systems; yet legal perspective will not deal with such actions or inactions, for law permits their exclusion." Change is not the only challenge to the legal approach. The use of terminology sets certain limits as well.

The term "white collar crime" was coined by Edwin Sutherland at the American Sociological Society meeting in 1939. Sutherland defined the term as "crime committed by a person of respectability and high social status in the course of his occupation." White collar crime anticipates high skills of a criminal and sophistication of the criminal act. The Federal Bureau of Investigation (FBI) has adopted the narrow approach, defining white-collar crime: “...as those illegal acts which are characterized by deceit, concealment, or violation of trust and which are not dependent upon the application or threat of physical force or violence." "According to the FBI white collar crime is estimated to cost the United States more than $\$ 300$ billion annually. ${ }^{10}$

White collar crime does not contradict the definition of corruption and can be linked to corruption through the legal concept of commercial bribery. People tend to use area-specific stamps, such as corporate fraud, political graft, abuse of public property, embezzlement from state funds, breach of academic integrity, etc. Accordingly, white collar crime is attached to the corporate world, embezzlement and fraud to the public sector, student cheating and plagiarism to the world of academia, and research fraud to think tanks. This type of heuristics prevents one from considering the many instances of

${ }^{8}$ Sutherland, Edwin (1949). White Collar Crime. New York: Dryden Press.

${ }^{9}$ U.S. Department of Justice, Federal Bureau of Investigation (1989). White Collar Crime: A Report to the Public. Washington, D.C.: Government Printing Office. p. 3.

${ }^{10}$ Legal Information Institute. Cornell University Law School. Retrieved October 15, 2007, from http://www.law.cornell.edu/wex/index.php/White-collar_crime 
corruption that take place in the education sector. Media reports and the results of investigations indicate that all of those forms of misconduct are common in higher education.

\section{Selection criteria for legal cases}

The cases of corruption in higher education considered in US courts include fraud in educational loans, quality of educational programs, credentials, credentials evaluation and accreditation, attempts to monopolize discretion over the admissions decisions, collusion, embezzlement, research misconduct, and fraud. ${ }^{11}$

This chapter uses the following selection criteria for choosing legal cases for consideration: degree of corruption, level of explicitness, scale and scope, significance, precedent, level of publicity, total funds at stake, and future prospects, including both domestic and international applications. Specifically, it focuses on cases that take place in higher education, positioned in so-called grey area or uncharted waters of legislation, yet may be highly explicit and deemed inappropriate or unethical, and significant and promising in terms of their scale and scope. They may become a precedent in legal practice as related to domestic laws applied to the US higher education sector.

At the same time, this study extends its reach in two critically important directions. First, it overcomes conventionally imposed limitation on cases of corruption as occurring in the public sector only. Second, it considers cases where higher education institutions

${ }^{11}$ See court cases and decisions at West's Federal Practice Digest $4^{\text {th }}, 18 \mathrm{~A}$ and 18B, Colleges and Universities, St. Paul, MN: West Group, 1999; and West's Federal Practice Digest $4^{\text {th }}, 18 \mathrm{~B}$, Colleges and Universities, Cumulative Annual Pocket Part. St. Paul, MN: West Group, 2007. 
interact with both the state and private for profit entities. The heavy involvement of state and federal funds along with state and federal regulations attached to funding, as well as the state interests in higher education in a broader sense form the bridge that connects the public and private sectors. This permits an analysis of corruption independently from the form of property of a given higher education institution.

This chapter considers corruption in higher education through the legal cases, following publications, legal records, and court cases in the United States (US). The major focus is on the few selected cases of corruption in US higher education. Some of these cases are broadly publicized in the media and discussed in scholarly literature. ${ }^{12}$ Others are only briefly mentioned in the specialized media sources that focus on problems of higher education, even though they may represent a legal precedent with a potentially large future impact on the industry. ${ }^{13}$ They are significant and affect large number of higher education institutions and constituents, including educators, students, parents, and general public. The legal cases to be analyzed are at the core of the development and the reform of higher education industry. They reflect processes of decentralization, commercialization, and marketization of higher education along with the processes of coordination, quality assurance, and state control in the industry.

This research carries certain limitations, which are expressed in the set selection criteria. The selection criteria restrict the study to significant cases of corruption in higher education, and hence preserve the high degree of relevance of the conducted research,

${ }^{12}$ See, for instance, the price fixing investigation of the so-called Overlap group in 1991, reflected in some scholarly work, including Sykes, Carol. (1988). ProfScam: Professors and The Demise of Higher Education. Washington, D.C.: Regnery Gateway.

${ }^{13}$ See, for instance, Van Der Werf, M. (2006, August 6). Lawsuit U. The Chronicle of Higher Education, 52(48), p. A23. 
while at the same time maintaining a reasonable level of abstraction in order to purify the legal cases and focus on their essence. For instance, if the United States Code Service (USCS $)^{14}$ reports on a case of embezzlement of public funds, committed by an administrative staff member in a public higher education institution, this case will not be considered in this study. First of all, embezzlement is not limited to the higher education sector. This practice is not distinct but rather common for all the industries, including both public and private sectors. Second, the case of embezzlement is clear and is therefore not worthy of study. However, the way the court determined whether the case should be considered under the corruption law may be of interest, as it implies problem of definitions.

In a case where a university administrator and a custodian or subcontractor collide in order to unlawfully benefit from a certain operation, a court will only consider the case if the net benefit obtained in an illegal way sums up to five thousand dollars or higher. If, however, the net benefit will be lesser than five thousand dollars, the state statutes on corruption will not apply. Hence, if a public university overpaid a private contractor for the services rendered as a result of improper collusion between the administrator and subcontractor, the court will focus on the sum of the immediate damage.

This study tends to focus on the nature and the essence of a particular misdeed, rather than on the net benefit and the appropriate statutory limitations that may apply, depending on the state legislation. Simply put, for the court, the issue is both illegality and the size of illegally obtained benefit, while for this study the case of corruption exists no matter whether the total benefit was less than five thousand dollars or more than five

${ }^{14}$ United States Code Service: Lawyers Edition. Crimes and Criminal Procedures $\S \S 1-430$. Title 18 USCS. 
thousand dollars. In addition, if an alleged collusion took place between relatives, then this study would classify such a case as an example of embezzlement, nepotism, and committed fraud. Another limitation is concerned with clear cases of corruption. In such cases, no additional research is needed to establish the case of corruption, since it was already established by the court.

\section{Legal cases: description and essence}

Major cases under the False Claims Act include US versus University of Phoenix, US versus Oakland City University, and US versus Chapman University. In the case of University of Phoenix, the complaint says that the institution certified that it was in compliance with all the US Department of Education regulations when it paid recruiters based on how many applicants they enrolled. This constitutes a direct violation of the law. The complaint was dismissed in US District Court in Sacramento and is now on appeal at the U.S. Court of Appeals for the Ninth Circuit.

Similar to University of Phoenix, Oakland City University is accused of violating the False Claims Act. The case is considered a precedent because the Seventh Circuit of the US Court of Appeals ruled that the university knew it was illegal to pay recruiters and deceived the US Department of Education in order to obtain a certification of eligibility to receive federal funds.

In the case of Chapman University, the complaint says that the institution, as part of the accreditation process, certified that it was giving the required amount of classroom instruction in its academic programs, when it was not. If it had revealed the truth, the 
complaint alleges, Chapman would not have been accredited and would be ineligible to receive federal grants and student loans. The case is active before US District Court in Santa Ana, CA, because the judge denied a motion to dismiss it.

One of the most interesting legal cases that has developed over the last twelve months, starting in February of 2007, is a set of investigations launched by the Attorney General of the State of New York, Mr. Cuomo, that looks into educational lending practices and other related issues. The investigation discovers possible misdeeds in the link between numerous colleges and universities and businesses. In addition, other abuses of students as consumers, such as false advertisements in study abroad programs, have also become objects for investigation.

New York has a rich history of corruption. This may be explained in part by the presence of a large diverse mega-polis, New York City, and a large public sector, including public education. Large scale public projects and social programs, such as education, healthcare, public housing, transportation, utilities, and such, significant financial flows and monetary transactions, complexity of the system of public and private contractors and subcontractors, large bureaucratic apparatus, and complex relations between the state and the private sector create an ideal environment for corruption. As the result, there is a relatively well developed and detailed legislation on corruption, bribery, graft, and fraud in New York State as compared to other states. Numerous precedents and cases decided in state courts present an opportunity to research corruption in higher education in the legal context.

The Attorney General has been leading an ongoing investigation into the student loan industry. He requested information from more than sixty public and private colleges 
and universities nationwide regarding the standards they use to determine which lending companies are included on their "preferred lender" lists. Financial aid administrators often produce such lists to direct their students toward the lenders that are most preferred by the schools but may not offer the best deals for students and parents.

The Attorney General's Office plans to file a law suit against Education Finance Partners (EFP), a student loan lender that operates in the growing industry educational loans. ${ }^{15}$ Investigations conducted by Mr. Cuomo revealed the existence of specific arrangements between the EFP and over sixty colleges and universities, including Fordham University, Long Island University, St. John's University, Boston University, Clemson University, and Baylor University. A formal notice has been issued to the EFP that the Attorney General's office will be filing suit over deceptive practices in the company's student loan business. The suit is the first filed in a nationwide investigation into the college loan industry. Specifically, the EFP was accused of paying kickbacks to colleges and universities that consistently placed the company on the preferred loan providers list.

The initial investigation conducted by the Attorney General has revealed that "Education Finance Partners has repeatedly paid schools in exchange for steering loans to EFP and for putting EFP on 'preferred lender' lists. Approximately $90 \%$ of students choose their lenders from their school's preferred lender lists. Cuomo's investigation has uncovered that neither the schools nor EFP adequately disclose to students that EFP is paying the schools to be promoted as a 'preferred lender.' Cuomo's legal action alleges that the relationship and financial arrangements between EFP and the schools constitute a

${ }^{15}$ See Appendix A, Notice of intention to sue. 
deceptive business practice. Cuomo also revealed today that EFP made its financial kickback arrangements with schools through what are called revenue sharing agreements, which often were based on a tiered system that would give a higher percentage to the schools based on the amount of loans referred."16

The arrangement of rewarding colleges by the lender that can mount to the practice of paying kickbacks resulted in potentially large amounts of money paid by the EFP to universities participating in the preferred lender program. For example, the EFP's agreement with Duquesne University gives the school 60 basis points, i.e. 0.6 percent of the net value of all referred loans. The agreements are structured to encourage the schools to refer as much business as possible to the EFP. For example, the EFP's agreement with Boston University provides that Boston University will receive 25 basis points or 0.25 percent of the net value of referred loans of at least $\$ 1,000,000$ up to $\$ 5,000,000 ; 50$ basis points or 0.5 percent of value of referred loans between $\$ 5,000,000$ and $\$ 10,000,000$; and 75 basis points or 0.75 percent of the net value of referred loans over $\$ 10,000,000 .{ }^{17}$

Mr. Cuomo accuses that some schools, such as Drexel University in Philadelphia, received over $\$ 100,000$ in kickbacks from the EFP in a single year. Under Drexel's agreement with the EFP, dated April 1, 2006, Drexel has agreed to make the EFP its "sole preferred private loan provider." In return, the EFP has agreed that Drexel will receive 75 basis points ( .75 percent) of the net value of referred loans between $\$ 1$ and $\$ 24,999,999$; and 100 basis point (1 percent) of all loan amounts of $\$ 25,000,000$ or greater. Furthermore, the Attorney general alleges that the EFP engaged in deceptive

${ }^{16}$ Attorney General Andrew Cuomo announces first legal action in college loan industry investigation (March 22, 2007). Retrieved from http://www.oag.state.ny.us/press/2007/mar/mar22b_07.html

${ }^{17}$ Ibid. 
marketing practices by using schools' logos, mascots, and names in the EFP promotional materials to imply that the EFP had the school's official endorsement: "EFP's marketing practices were clearly intended to imply that the universities had endorsed EFP loan products for individual student borrowers. Deceptive marketing is just that and it limits the information available for students to get the best deal in their college loans." ${ }^{18}$

The named cases are clear candidates for legal precedents, insofar as these cases reflect on deeds that take place in higher education and positioned in grey areas. Such cases await legal interpretations that will likely be influenced by a socio-economic context rather than by previous precedents in similar circumstances alone. The summary of the reviewed cases is presented in Table 3 .

18 Ibid. 
Table 3

Cases on the grounds of the False Claims Act, Consumer Protection Act, Higher Education Act, and Anti-Trust Laws after 2000

\begin{tabular}{|c|c|c|c|c|c|c|c|c|}
\hline \multirow[t]{2}{*}{ University } & \multirow[t]{2}{*}{ Plaintiff } & \multirow[t]{2}{*}{ Ground } & \multirow[t]{2}{*}{ Date filed } & \multirow[t]{2}{*}{ Date settled } & \multicolumn{2}{|c|}{$\begin{array}{l}\text { Settlement } \\
\text { (in millions) }\end{array}$} & \multirow[t]{2}{*}{ Allegations } & \multirow[t]{2}{*}{ Essence } \\
\hline & & & & & Total & Plaintiff & & \\
\hline $\begin{array}{l}\text { University of Phoenix, } \\
\text { Apollo Group }\end{array}$ & $\begin{array}{l}\text { Former employees } \\
\text { (two admissions } \\
\text { officers) }\end{array}$ & $\begin{array}{l}\text { False Claims } \\
\text { Act }\end{array}$ & Mar. 2003 & Dec. 2009 & $\$ 78.5$ & $\$ 28.0$ & $\begin{array}{l}\text { Incentive pay } \\
\text { for recruitment }\end{array}$ & $\begin{array}{l}\text { state and } \\
\text { consumer } \\
\text { fraud }\end{array}$ \\
\hline Oakland City University & $\begin{array}{l}\text { Former employee } \\
\text { (one director of } \\
\text { admissions) }\end{array}$ & $\begin{array}{l}\text { False Claims } \\
\text { Act }\end{array}$ & Mar. 2003 & July 2007 & $\$ 5.3$ & $\$ 1.4$ & $\begin{array}{l}\text { Incentive pay } \\
\text { for recruitment }\end{array}$ & $\begin{array}{l}\text { state and } \\
\text { consumer } \\
\text { fraud }\end{array}$ \\
\hline Chapman University & $\begin{array}{l}\text { Former employees } \\
\text { (three instructors) }\end{array}$ & $\begin{array}{l}\text { False Claims } \\
\text { Act }\end{array}$ & Mar. 2005 & pending & - & - & $\begin{array}{l}\text { Insufficient } \\
\text { instruction } \\
\text { time }\end{array}$ & $\begin{array}{l}\text { state and } \\
\text { consumer } \\
\text { fraud }\end{array}$ \\
\hline Corinthian Colleges Inc. & $\begin{array}{l}\text { State on behalf of } \\
\text { consumers, (class- } \\
\text { action) }\end{array}$ & $\begin{array}{l}\text { Consumer } \\
\text { Protection } \\
\text { Act }\end{array}$ & & July 2007 & $\$ 6.5$ & $\$ 5.8$ & \begin{tabular}{|l|} 
False \\
advertising, \\
unfair business \\
practices
\end{tabular} & $\begin{array}{l}\text { consumer } \\
\text { fraud }\end{array}$ \\
\hline $\begin{array}{l}\text { Education Finance } \\
\text { Partners } \\
\text { (private student loan } \\
\text { provider) }\end{array}$ & $\begin{array}{l}\text { State on behalf of } \\
\text { consumers, (class- } \\
\text { action) }\end{array}$ & $\begin{array}{l}\text { Higher } \\
\text { Education } \\
\text { Act, Anti- } \\
\text { Trust }\end{array}$ & Mar. 2007 & Apr. 2007 & $\$ 2.0$ & $\$ 0$ & $\begin{array}{l}\text { Preferred } \\
\text { student loan } \\
\text { providers list }\end{array}$ & $\begin{array}{l}\text { consumer } \\
\text { fraud, } \\
\text { kickback }\end{array}$ \\
\hline $\begin{array}{l}\text { Dozens of public, private, } \\
\text { and private for-profit } \\
\text { colleges; a dozen private } \\
\text { student loan providers }\end{array}$ & $\begin{array}{l}\text { State on behalf of } \\
\text { consumers, (class- } \\
\text { action) }\end{array}$ & $\begin{array}{l}\text { Higher } \\
\text { Education } \\
\text { Act, Anti- } \\
\text { Trust }\end{array}$ & Mar. 2007 & Feb. 2008 & $\$ 14.0$ & $\$ 0$ & $\begin{array}{l}\text { Preferred } \\
\text { student loan } \\
\text { providers list }\end{array}$ & $\begin{array}{l}\text { consumer } \\
\text { fraud, } \\
\text { kickback }\end{array}$ \\
\hline
\end{tabular}

Source: Completed by the author 


\section{Analysis and discussion: legal cases in the context}

The analysis and the discussion of legal cases presented in this study seek to answer the following questions. First, what is in the essence of each case? What are the underlying interests of groups involved, including consumers of educational services, providers of educational services, regulatory authorities, legislators, and the state in general? Second, is the case new or there were earlier precedents or attempts to create a precedent on a similar case? Third, are there new ways to interpret old rules and laws that are used in the case? Fourth, how is the case positioned in the context of educational reforms and socio-economic processes in the society in general? This study addresses sequences of events or cases, existing established and possible ties, common fundamentals for different or similar cases, socio-economic context, trends in the education industry, and processes of modernization and reform in the society.

There is also an additional set of questions that may be addressed in the analysis and the discussion. This additional set includes the following major questions. First, what is the degree and direction of the governmental interference in each of the cases? Here, we attempt to consider the government in a broader sense than just a legislative branch that includes prosecutors and the court system. Second, what are the possible future implications of the processes, cases, and legal decisions made? Are there any spillovers or potential for spillovers on other national educational system? Broader spillovers on the European Union and the developing nations may be possible. Third, do the findings support our definition of corruption in higher education? 
The case of the US versus University of Phoenix in 2006 points to the federal funds received by the University in form of student aid. The University might have been ineligible because of the non-compliance with the certain federal laws and regulations. The case is being developed on the ground of the False Claims Act and anticipates possible fraud in state-university relations. Chapman University received federal funds in form of student aid, but might have been ineligible as well. The major challenge in the case considered in 2006 was the instruction time necessary to receive credit hours. As a result, students might have been defrauded because of the insufficient instruction time and the state was defrauded as well.

Possible corruption takes place in student-university relations and in stateuniversity relations. The State of New York Attorney General launched an investigation in 2007 to discover some doubtful practices with lists of preferred providers of student loans, administered by colleges' financial aid officers. The case points to possible attempts to establish near-monopoly and to defraud students on the local markets of educational loans. The case involves state-university relations and student-university relations. The government conducted the investigation on the basis of students being defrauded and guided to more expensive loans by college administrators.

Cases built on the ground of anti-trust regulation have been considered before. One of the major cases that attempted to establish possible corruption in admissions involved MIT and a number of other Ivy League colleges in 1990. The colleges were making agreements prior to admitting graduate students in order to reduce the total cost of the offerings in form of scholarships and financial aid. This implies monopoly in admissions, collusion, and consumer fraud. The colleges admitted wrongdoing and 
stopped the practice, while MIT won on appeal, pointing to its non-profit status. Another broadly publicized case of 1985 involved Stanford University and later few other colleges. The major consideration here was overhead payments of up to 74 cents on every $\$ 1$ received in form of federal grants as well as the ways in which some of the federal research money were spent. ${ }^{1}$ The case implied possible fraud in state-university relations. It is within the Attorney General's purview to prosecute cases that imply monopolistic agreements. $^{2}$

A number of cases involving diploma mills included state-university relations, consumer-university relations, and degree holder-employer relations. Cases of educational quality fraud involve consumers or students, providers or colleges, and accreditation agencies. Research fraud involves the state as the major source of funding, while the medical fraud committed in university hospitals involves patients and insurance companies.

The cases of corruption in higher education selected for this study include the most recent developments in college funding, including ties between colleges and the educational loans industry. The investigation was initiated by the Attorney General of the State of New York Mr. Cuomo and followed by another twenty seven states throughout the country. Two other cases based on the False Claims Act include a for-profit

${ }^{1}$ Anderson, Martin. (1992). Impostors in the Temple: American Intellectuals Are Destroying Our Universities and Cheating Our Students of Their Future. New York: Simon and Schuster.

2 The attorney general had power to prosecute for offences committed as part of the means, plan, or scheme by which violations of $\$ 340$, prohibiting monopolies were effected, and any criminal act done in furtherance of a violation of such section was subject to investigation and prosecution by the attorney general. People v. Dorsey, 1941, 176 Misc. 932, 29 N.Y.S.2d 637. McKinney’s Consolidated Laws of New York Annotated. Book 19. General Business Law. Thomson West. 2004. p. 318. 
educational institution based in California that was accused by the state of defrauding its students, playing on the mismatch between students' financial aid and academic abilities and the case with the University of Phoenix. In the first case, there was a settlement achieved and the university ultimately agreed to a settlement of $\$ 6.5$ million in restitutions, penalties, fines, and compensatory payments, while the second case is still under review.

The recent scandals of university financial aid officers, preferred educational loan providers list, and possible kickbacks were highlighted in several issues of The Chronicle of Higher Education in April-August 2007, can be analyzed through the proposed classification frame. This will help to understand whether the cases represent corruption of higher education and what is in the essence of each case. In cases investigated by the State Attorney General Mr. Cuomo, financial aid officers suggested a particular private bank-lender to students. The bank may not have the best offerings for the students and would be ruled out otherwise. The non-competitive bank loan offers attract clients. This may constitute fraud. And fraud is a phenomenon of corruption. The next question is whether this is an intentional fraud or it is a result of negligence or incompetence. Intentional fraud takes place if financial aid officers commit it in expectation of personal or material gain. Material gain can come through holding shares in the bank placed on the preferred loans provider list and through receiving kickbacks in the form of consultation fees, gifts, etc. Accordingly, the means of corruption are kickbacks. Banks might pay kickbacks deceptively worded as "referral affiliate benefit packages" to colleges' financial aid officers in the form of gifts, meals, accommodations, consulting fees, travel expenses, registration fees, tuition waivers, and shares of the lending 
agencies. Being on the preference lender list increases the profitability of the bank, the profitability of the shares, and, hence, the revenue of the shareholders. Such practices raise several questions: Does this represent clear conflict of interest? Is this illegal? Is this against the university rules? Are such practices transparent? What rules are established and by whom?

The locus of corrupt activities in this case includes access to higher education and possible breach of contract. The area primarily affected is access to higher education since loans are intended to fund the studies. Educational loans provided on noncompetitive ground or not the best possible terms and conditions reduce the degree of accessibility of higher education, increase student debt, and eventually lead to the withdrawal of more competitive providers from the market. The practice of having a list of preferential loan providers may also constitute a breach of contract between the student and the university. This is only possible if universities are under the obligation to provide their current and prospective students with the best possible options in terms of educational loans, both private and public.

The possibly corrupt interactions in the presented case include: businessuniversity relations with possible collusion between banks-providers of educational loans and universities or admissions officers; relations between students and college administration, where administrators commit possible fraud by presenting students with the preferred lenders list; and, finally, interactions between the state and higher education institutions, including the investigation conducted and out-of-court settlements achieved, as well as restitutions and voluntary acceptance of the code of conduct set by the state for the future. 


\section{Legal argumentation}

Definitions of bribery are arguable. One of the issues that may be raised in connection with alleged kickbacks to particular college financial aid officers may be loans and tuition waivers that they received from for-profit providers of educational loans. People versus Hyde case of 1913 in the State of New York dismissed the charges of corruption on the ground that the fact of obtaining a loan itself does not constitute corruption unless the direct benefit to the loan receiver is proven. ${ }^{3}$

The definitions of bribery are structured so to address donor and recipient issues or, as they are called in legal documents, bribe receivers and bribe givers. Bribe giving and bribe receiving can be of first, second, and third degree and constitute three different classes of felonies, accordingly. As related to bribe giver, $\$ 200.00$ of the Consolidated Laws of New York states that "A person is guilty in the third degree when he confers, or offers or agrees to confer, any benefit upon a public servant upon an agreement or understanding that such public servant's vote, opinion, judgment, action, decision or exercise of discretion as a public servant will thereby be influenced." ${ }^{\prime 4}$ As related to bribe

3 "In order to constitute bribery within the meaning of former Penal Law 1909, $\$ 372$ [now this section], it must be shown that the officer received some personal advantage, pecuniary or otherwise, that influenced his action or decision, and the fact that a city chamberlain received a loan in consideration for depositing moneys of the city in a certain bank does not constitute bribery in the absence of proof that the loan was in fact an advantage to him." People v. Hyde (1 dept. 1913) 156 A.D. 618, 141 N.Y.S. 1089. McKinney's Consolidated Laws of New York Annotated with Practice Commentaries by William C. Donnito. Book 39. §170.00 to 219.end. West Group, 1999, p. 278.

${ }^{4}$ McKinney's Consolidated Laws of New York Annotated with Practice Commentaries by William C. Donnito. Book 39. $\$ 170.00$ to 219.end. West Group, 1999. p. 259. Article 200. Bribery involving public servants and related offences, p. 267. 
receiver, §200.10 states that “A public servant is guilty of bribe receiving in the third degree when he solicits, accepts or agrees to accept any benefit from another person upon an agreement or understanding that his vote, opinion, judgment, action, decision or exercise of discretion as a public servant will thereby be influenced." ${ }^{, 5}$ There are also such terms as rewarding official misconduct and receiving reward for official misconduct and giving and receiving unlawful gratuities.

Bribes do not have to be in monetary form, but can be present in any form possible that conveys the benefit to bribe receiver. In People versus Hochberg case of 1978 it was established that "Benefit accruing to public official need not be tangible or monetary to constitute a 'bribe'., ${ }^{6}$ Sex can also be considered as a form of a bribe. People versus Teitelbaum court case of 1988 points to a clear case of corruption of government officials with sexual services being used as a bribe: "Evidence that police officers had told narcotics offender that everything would be alright if she accompanied officers to apartment, and that offender had subsequently performed oral sex on officers, was sufficient to support officers' conviction for bribe receiving in second [now third] degree."

The scope of authority does not limit the responsibility for bribery. ${ }^{8}$ Bribe giving anticipates a clear expectation that the public officer, i.e. bribe receiver or recipient

\footnotetext{
${ }^{5}$ Ibid, p. 275.
}

${ }^{6}$ People v. Hochberg (3 dept 1978) 62 A.D.2d 239, 404 N.Y.S.2d 161, McKinney's Consolidated Laws of New York Annotated with Practice Commentaries by William C. Donnito. Book 39. \$170.00 to 219.end. West Group, 1999, p. 271.

${ }^{7}$ People v. Teitelbaum (2 Dept. 1988) 138 A.D.2d 647, 526 N.Y.S.2d 230. McKinney's Consolidated Laws of New York Annotated with Practice Commentaries by William C. Donnito. Book 39. §170.00 to 219.end. West Group, 1999, p. 279.

8 "It is sufficient to justify conviction for bribery if officer to whom bribe was offered assumed under color of his office to perform function belonging to his office, 
retains the authority to help the donor to cross the red tape, i.e. overcome the restrictions set by the law or by the public officer himself/herself. It does not matter whether the public servant actually has a power or authority to meet the expectations of the donor and to match his/her demands in full. People versus Graham case of 1977 points out that the public official is "assumed to have power" by the bribe giver. ${ }^{9}$

Agreement or mutual understanding is an essential characteristic of a corrupt transaction. The expectation of crossing the red tape should be present at least on the side of the bribe giver. People versus Tran case of 1992 found that "'Agreement or understanding' is the key element of the bribery statutes. The 'agreement' between the bribe giver and the bribe receiver must be mutual. Alternatively, the 'understanding' must be at least a unilateral 'perception $r$ belief' in the mind of the bribe giver that the bribe 'will' influence the receiver's conduct. If the bribe giver offers or confers a benefit with only the intent that the bribe receiver's conduct be influenced thereby, or with only a 'mere hope' that the receiver's conduct would be influenced thereby, the crime of bribery is not committed." 10

Bribe giver or donor is not necessarily the initiator of a corrupt transaction. Extortion is another form of corruption that takes place when a public officer in charge demands a bribe from a potential donor in exchange for the officer's action or inaction in

even if right to perform function did not exist. People v. Chapman, 1963, 13 N.Y.2d 97, 242 N.Y.S.2d 200, 192 N.E.2d 160. McKinney's Consolidated Laws of New York Annotated with Practice Commentaries by William C. Donnito. Book 39. §170.00 to 219.end. West Group, 1999, p. 271.

9 “'Bribery' is offering to public servant benefit to induce him to act or refrain from acting in matter over which he may be assumed to have power. People v. Graham (4 dept. 1977) 57A.D.2d 478, 394 N.Y.S.2d 982, affirmed 44 N.Y.2d 768, 406 N.Y.S.2d 36, 377 N.E.2d 480. p. 269.

${ }^{10}$ People v. Tran, 1992, 80 N.Y.2d 170. p. 260 
favor of the donor. Coercive power is usually used by the public servant in order to extort a bribe. The fact of extortion does not substitute for bribery, because extortion results in bribe. According to the Consolidated Laws of New York, "It is expressly made no defense to bribe receiving that the defendant was extorting or coercing a bribe and could therefore be guilty only of extortion or coercion, not bribe receiving [\$200.15]."11

In case of extortion, the donor is protected from the legal responsibilities that would normally apply to a bribe giver in a typical case of bribery. The special provision was introduced for such a protection, because in the case of extortion the donor is considered a victim of corruption rather than an accomplice. The Penal Law in New York State holds the donor harmless on the ground that he/she is a victim of coercion or extortion. $^{12}$

Corruption is not limited to bribery involving public servants and related offences. Legislation outlines yet another type of bribery, commercial bribery. ${ }^{13}$ Commercial bribery anticipates damage to employer. This makes commercial bribery a classical case of the principal-agent problem. Accordingly, numerous theoretical developments within the principal agent frame, made in economics and political science, may be applied to

${ }^{11}$ McKinney's Consolidated Laws of New York Annotated with Practice Commentaries by William C. Donnito. Book 39. §170.00 to 219.end. West Group, 1999. Article 200, §200.05. Bribery involving public servants and related offences, p. 264.

12 "Upon the declaration that bribe receiving and extortion were not mutually exclusive crimes, the bribe giver who was the victim of extortion would no longer be able to defend on that basis. This, out of arguable 'equitable considerations' [compare Model Penal Code \$240.1], a special defense to bribery was formulated which in essence held the giver harmless if the giver gave in response to extortion or coercion [\$200.05]." Staff Comments of the Commission on revision of the Penal Law. Revised Penal Law. McKinney's Spec. Pamph, (1965), p. 291.

${ }^{13}$ McKinney's Consolidated Laws of New York Annotated with Practice Commentaries by William C. Donnito. Book 39. §170.00 to 219.end. West Group, 1999. Commercial bribery, p. 122. 
commercial bribery. The point we want to make in this chapter is that the legal concept of bribery extends beyond the notion of public officer, i.e. that the employee who betrays his/her principal does not have to be a public employee. Accordingly, the state does not have to be involved. Involvement of the state through the state representatives is no longer a necessary precondition for the case to be considered within the realm of bribery and corruption.

The essence of bribery is in the intent to influence conduct of someone in charge of certain functions, duties, or responsibilities. In case of corrupt public official, the abuse is of the public, since the official represents interests of the public. But not all states or political regimes represent best interests of the public. Therefore, corruption is not limited to public officials or public sector. According to Consolidated Laws of New York, "The essence of bribery ... is in the 'intent' to influence improperly the conduct of another by bestowing a benefit, and the essence of bribe receiving is in the 'agreement or understanding' that the recipient's conduct will be influenced by the benefit." 14 This definition does not imply the participation of a public official or a public servant. Nor it implies any involvement of the state.

Commercial bribery can be of two degrees. If the case of bribery was at the stage of intent or agreement, then it would qualify as a commercial bribery of second degree. If, however, the transaction itself would take place and there would be clear damage to the interest of the principal resulting out of such transaction, then commercial bribery would qualify as first degree. The Statutes of New York set a total benefit benchmark of $\$ 1000$

${ }^{14}$ McKinney's Consolidated Laws of New York Annotated with Practice Commentaries by William C. Donnito. Book 39. $\$ 170.00$ to 219.end. West Group, 1999. Commercial bribery, p. 122. 
for the benefit to participating parties in a corrupt transaction and a damage of $\$ 250$ to the principal, betrayed by his/her agent. ${ }^{15}$

Higher Education Act of 1965 regulates the sphere of educational loans in the US. However, some issues of consumer rights protection as well as state and federal jurisdictions are still not clear. Parents can borrow a PLUS loan to cover education expenses for dependent undergraduate students enrolled at least half time in an eligible program at an eligible school. PLUS loans are available through the Federal Family Education Loan (FFEL) Program and the William D. Ford Federal Direct Loan Program. Eligibility of a student anticipates high school diploma, eligibility of parents anticipates good credit, and eligibility of the program and the college anticipates accreditation. Conditionality is attached to all governmental educational loans and certain conditions apply to all the participants of this type of contract or transaction. At the same time colleges may be found under no responsibility to provide quality educational services to students and hence students can not return their payments made out of state loans, if no federal loans are involved. ${ }^{16}$ Student loans, made, issued, or guaranteed, under Higher

15 "If the value of the benefit exceeds $\$ 1000$, and as a consequence of the bribing or bribe receiving there is economic harm to the employer or principal in excess of $\$ 250$, the crimes are aggravated to commercial bribing in the first degree.” McKinney's Consolidated Laws of New York Annotated with Practice Commentaries by William C. Donnito. Book 39. §170.00 to 219.end. West Group, 1999. Commercial bribery, p. 123.

${ }^{16}$ C.A.7(Ind.) 1990. Students could not seek rescission of student loans guaranteed by state and private agencies on theory that, because of close connection between solvent business college and lenders and other defendants, defendants were subject to defense based upon college's failure to provide student with education; since loans were guaranteed by private and state agencies, rather than federal government, they were not subject to protections of federal regulations, under which defense might be available in cases involving Federal Insured Student Loans and federal PLUS loans. Higher Education Act of 1965, §401 et seq., as amended, 20 U.S.C.A. $§ 1070$ et seq. Veal vs. First American Savings Bank, 914 F.2d 909, rehearing denied. Source: West's 
Education Act are also exempt from federal trade Commission rule on preservation of consumer defenses. ${ }^{17}$

The issue of educational loans and all the abuse associated with it extends beyond interactions between students and colleges, since colleges themselves do not hold student loans. The decision made in Veal versus First American Savings Bank states that "Rule that assignee who is not holder in due course takes instrument subject to defenses against assignor existing at time of assignment could not be used to charge lenders who granted guaranteed student loans with alleged fraudulent activities of insolvent business college, since college was never "holder" of student notes and lenders were never assignees of college." 18 This provision points to the need to better educate consumers about educational and affiliated financial services. Consumers of educational services must be aware of quality, accreditation level, terms and conditions of educational loans, etc.

Cuomo investigations of educational loans and study abroad programs are based on the provision that deceptive acts and practices are unlawful under the Consumer and Borrower Protection Act. As stated in the New York State legislation, "Deceptive acts or practices in the conduct of any business, trade or commerce or in the furnishing of any

Federal Practice Digest $4^{\text {th }}, 18 \mathrm{~B}$, Colleges and Universities, St. Paul, MN: West Group, 1999 , p. $9.25(2)$

${ }^{17}$ Student loans, made, issued, or guaranteed, under Higher Education Act are exempt from federal trade Commission rule on preservation of consumer defenses, under which consumer credit contracts must advice holders of such contracts that they are subject to all claims and defenses that debtor has against seller of goods and services. Consumer Credit Protection Act, $§ 104(6)$, as amended, U.S.C.A. §1603(6). Veal vs. First American Savings Bank, 914 F.2d 909, rehearing denied. Source: West's Federal Practice Digest $4^{\text {th }}, 18 B$, Colleges and Universities, St. Paul, MN: West Group, 1999, p. $9.25(2)$

${ }^{18}$ Higher Education Act of 1965, $\$ 401$ et seq., as amended, 20 U.S.C.A. $\$ 1070$ et seq.; West's A.I.C. §26-1-3-306. Veal vs. First American Savings Bank, 914 F.2d 909, rehearing denied. Source: West's Federal Practice Digest $4^{\text {th }}, 18 \mathrm{~B}$, Colleges and Universities, St. Paul, MN: West Group, 1999, p. 9.25(2) 
service in this state are hereby declared unlawful." ${ }^{19}$ In case of private educational loans, the consumer and borrower protection considers borrower as a consumer of financial services. This requires transparency and full disclosure of the terms and conditions under which the loan is furnished to the student and served by the student.

According to the Consumer Protection Act, "The essential elements of a violation of New York law prohibiting deceptive acts or practices in the conduct of any business, trade, or commerce or in the furnishing of any service in New York are: (1) proof that a “consumer-oriented" practice was deceptive or misleading in a material respect, and (2) proof that plaintiffs were injured thereby." ${ }^{20}$ But there is a safe harbor for lenders and college financial aid officers that may be found in the state legislation. Specifically, the court does not accept claims about deceptive practices when such practices were fully disclosed to the consumer. ${ }^{21}$

The excursion into the legal definitions and peculiarities leaves many questions unanswered. For instance, both coercion and extortion are considered in legislation. However, the bribe giver in such cases is considered a victim. But what about public employees and elected officials who are coerced by their supervisors to solicit bribes and accept bribes? This anticipates the corruption and coercion policy as a mechanism of

${ }^{19}$ Article 22-A. Consumer protection from deceptive acts and practices. $\$ 349$. McKinney's Consolidated Laws of New York Annotated. Book 19. General Business Law. Thomson West. 2004. p. 320.

${ }^{20}$ Champion Home Builders Co. v. ADT Sec. Services, Inc., 2001, 179 F. Supp.2d 16, as amended. 10. Elements of action, generally. §349. Consumer protection, McKinney's Consolidated Laws of New York Annotated. Book 19. General Business Law. Thomson West. 2004. p. 333.

21 "There can be no claim for deceptive acts or practices when the allegedly deceptive practice was fully disclosed." Broder v. MBNA Corp. (1 Dept. 2001) 281 A.D.2d 369, 722 N.Y.S.2d 524. 11. Deceptive acts, generally. \$349. Consumer protection, McKinney's Consolidated Laws of New York Annotated. Book 19. General Business Law. Thomson West. 2004. p. 335. 
administrative control. And what about complex systems? The entire legal frame appears to be quite simplistic.

Legal provisions that exist in the legislation, including Higher Education Act, False Claims Act, and Consumer Protection Act and are presented in this chapter cover all the three areas: 1) corruption as related to the state (private individual bribes public official in order to obtain unduly benefits); 2) corruption as related to client and business (a client (subcontractor etc.) is abusing a business by bribing business' agent); and corruption as related to consumer and business (consumer fraud, when business deceives consumer). However, the legal frame is simplistic, while the system of interrelations in the higher education industry is rather complex.

\section{Implications}

Kaye, Bickel, and Birtwistle (2006) point out that "There is widespread concern that higher education is being compromised by being turned into a 'commodity' to be 'consumed'." The authors attempt to explore the trends in both the UK and US, and consider how the law has responded to them. They argue that "there is an important distinction to be drawn between 'commodification' and 'consumerism'. Education has always been a commodity to be bought and sold; the true danger lies in the move to a 'rights-based' culture where students (and politicians) see education merely as something to be 'consumed' rather than as an activity in which to participate. Whilst the law seems thus far to have been something of a bulwark against this movement, it remains an open 
question as to whether this will continue to be the case if HEIs do not themselves act more proactively in challenging this damaging view of higher education."

One can argue about the extent of consumerist approach in higher education across the nations, but the trend of presenting the higher education sector as a provider of educational services is obvious. The market mechanisms that are being introduced on an increased scale in higher education do not free the industry from corruption, including bribery and different other forms of misconduct. The equilibrium of supply and demand with consumers voting with their dollars for best possible choices do not necessarily lead to the elimination of public sector based corruption. Different forms of corruption exist in private sector as well. The legal definitions presented earlier explain why the range of investigations launched by the New York State Attorney General is under the auspices of consumer protection and fraud rather than corruption and bribery.

The case may necessitate development of certain measures, tools, and even institutions, such as the Consumer Education Fund established by the Attorney General of New York, as well as changes in legislation, designed to prevent doubtful practices in the future. Provision of private educational loans is a growing industry in the US. It rose sharply from $\$ 1.7$ billion in 1996 to $\$ 17$ billion in 2006 and is expected to grow continuously and rapidly in the future. Similar developments may take place in other nations in the future. The process of transferring education financing to private educational loans represents the major trend in the higher education funding and may soon be borrowed and adopted in other countries. Subsequently, legislative regulations and changes in the legislation are necessary as well as provisions in the university's code of conduct not only in the US, but in many other nations. 
The classification also points to some possible theoretical developments. The core of the problem as related to corruption is in an intentional restriction of students' access to reliable information about the available educational loans. This implies imperfect information, imperfect competition between the educational lenders, and a certain degree of monopolization of the market of educational loans and eventually brings into fore the antitrust law.

The Cuomo cases in higher education are clearly not those of subprime loans and predatory lending, yet. However, this may well be the case in the future. The Consumer Education Fund, established by Mr. Cuomo, is primarily focused on educating constituents on predatory lending issues. There is a legacy to this issue as well. In 2000, then HUD Secretary Mr. Cuomo joined forces with Treasury Secretary Lawrence Summers, former President of Harvard University to form the national predatory Landing Task Force. Investigations in inappropriate lending patterns in higher education are not a surprise but rather a natural development. The investigations of misdeeds in educational loans touch upon broader financial aid issues and then naturally develop into investigations in possible abuses in study abroad programs. The investigations may eventually address all the areas where consumer fraud in higher education has a potential or already takes place.

Colleges use practices of hidden fees and bundling products and services. Even if predatory landing and consumer deception do not fall under the corruption and bribery provisions, kickbacks do. Kickbacks are bribes that are promised in advance and clearly anticipate expectations on the side of the bribe giver. At the same time they are paid post factum and present certain guarantees to the donor. As the educational loan industry 
grows, so are the opportunities for abuse. This situation and what appears to be a long term trend in thee education industry can no longer be ignored by the authorities. ${ }^{22}$

Higher education loans constitute an $\$ 85$ billion per year industry, as rightly mentioned by the Attorney General in multiple legal documents. The sum itself is not big, but the industry is growing rapidly. ${ }^{23}$ According to the New York State Department of Education, two-thirds of all four year college graduates nationwide now have loan debt, compared with less than one-third of graduates in 1993. In New York State, 59 percent of undergraduates took out loans to finance their college education. The average student graduating from a four-year college in New York owes \$17,594 on graduation day. ${ }^{24}$

Lastly, the results of the investigations and intentions to sue point to the practice of what one would define as "admitting without admitting," when colleges and private providers of educational loans de facto admit the wrongdoing or misconduct, but de jure regarded as not guilty. Both the higher education institutions and the providers of educational loans that are under investigation agree to stop their doubtful practices, sign the Code of conduct offered by the Attorney general, and even contribute to the Consumer Education Fund, set by the Attorney General. This "voluntary" contribution,

22 "EFP aggressively offered schools cash kickbacks in exchange for business," Cuomo said. "This kickback scheme was widespread and took place from coast to coast, at colleges large and small, public and private. This lawsuit is just the beginning of an investigation that will show that lenders put market share above fair play. A preferred lender ought to mean that the lender is preferred by students for its low rates, not by schools for its kickbacks. With the cost of college rising every day, the last thing students want to hear is that their lender may be muscling aside a more competitive loan package." Attorney General Andrew Cuomo announces first legal action in college loan industry investigation (March 22, 2007). Retrieved from http://www.oag.state.ny.us/press/2007/mar/mar22b_07.html

${ }^{23}$ Retrieved January 31, 2008, from http://www.oag.state.ny.us/family/student_lending/student_lending.html

${ }^{24}$ Retrieved from http://www.oag.state.ny.us/press/2007/mar/mar22b_07.html 
made by for-profit enterprises, along with the refusal to admit any wrongdoing prevents from establishing a true court based legal precedent. At the same time, such half-victories achieved through bargaining and negotiations work as political dividends for Mr. Cuomo, who is an elected official.

The situation reminds a forceful offensive campaign of the state on the free enterprises with the demand for money. As follows from one of the settlements: "In recognition of the Attorney General's leadership in improving the circumstances under which education financing is made available to college students and consistent with Sallie Mae's commitment to educating the public about the financial aid process, Sallie Mae agrees to donate \$2 million to the New York Attorney General's national fund for educating high school seniors and their parents regarding the financial aid process."

\section{Conclusion}

The importance of the study of court cases on corruption in US higher education is threefold. First, court cases present additional lenses to study definitions and aspects of corruption in higher education that do not exist in other systems. Second, the national system of higher education with its mixture of public and private, non-profit and forprofit higher education is undergoing process of evolutionary changes that vary from state to state. The forms of corruption develop and change accordingly. Third, the US higher education shows pathways for reforms in numerous other national educational

${ }^{25}$ The report on the Settlement with Sallie Mae, April 11, 2007. Retrieved January 31, 2008, from http://www.oag.state.ny.us/family/student_lending/student_lending.html 
systems. Many national systems of higher education, including those of the former Soviet Bloc, undergo major changes and reforms moving toward the market-based systems that in many ways replicate higher education industry that exists in the US. Accordingly, forms of corruption that are currently present in the US education will eventually develop in the transition educational systems as well. Learning about the forms and mechanism through which corruption in US higher education perpetuates will help in predicting corruption in other national educational systems.

Those few works that address corruption in higher education focus entirely on the issue of access, including such aspects as admission, retention, and affordability. The issue of quality, not least fundamental, is still missing from the research on corruption in education. The legal frame offered in this chapter and applied in investigations of allegedly corrupt activities on the side of educational institutions allows for addressing both issues: access and quality. The selection of cases and their analysis point to problems in the access and the quality of higher education as well as the ways in which legislation and the judiciary may be used in such cases.

The processes of decentralization, marketization, commoditization, and privatization in higher education rise questions of accountability, transparency, quality, and access. Decentralized financing of higher education anticipates cost sharing based in part on educational loans. The decentralized US higher education that long been considered an exception among other developed nations now turns into a sector from which inferences are to be drawn. This anticipates spillovers of the problems, but not the solutions. Forms of corruption that long existed in the US education sector, including those in quality assurance through accreditation, compliance with state and federal laws, 
and provision of educational loans now have a perspective to develop in other educational systems as well.

The law and the legislative process in general are central not only to the way the US system is organized, but also to the way it operates and resolves current problems. This fully applies to US higher education. If an individual or an institution wants to resolve a certain problem, the solution may be found primarily within the court system. The judge is to decide and the decision is to be made based on laws.

National systems of higher education in other countries can be characterized as centralized systems with states often playing dominating role in most of the issues. Accordingly, the decisive power belongs to the executive branch, including the Ministry of education and other ministries that impose numerous regulations and restrictions, impose sanctions, and resolve current problems. If a higher education institution does not comply with certain rules and provisions and students' or state interest are compromised, the institution may well be placed on probation or closed, and the leaders of this institution may be reprimanded or replaced. The so-called administrative resource plays a key role in decision making and dispute resolution. Hence, while the problems faced by the US higher education industry and national education industries in other countries may be common, the solutions will have to be found in different areas. This statement explains why the essence of legal cases is important. 


\section{CHAPTER IV}

\section{CORRUPTION HIERARCHIES IN HIGHER EDUCATION}

\section{Introduction}

Countries of the former Soviet Bloc reform higher education faster than most European countries. Political, economic, ideological, language, and cultural factors are all important for the reform. One of the negative sides of the reform is growing corruption of higher education institutions and in the educational industry overall. Corruption, and higher education corruption in particular, is something known but not described theoretically. At the same time, increasing scale and scope of corruption in higher education in the countries of the former Soviet Bloc, as well as numerous other countries, urges better understanding of the problem within the context of socio-economic transformations.

This chapter presents an overview of the research on corruption in organizations and hierarchies and then develops models of corrupt organizations, including vertical structure, horizontal structure, and vertical hierarchy. Possible future structures of corrupt organizations are presented as forms of evolution of horizontal structures. The three organizational forms of corruption as well as their possible future developments are projected on higher education. Suggestions for future research of corruption in organizational perspective are presented in the conclusion. 


\section{Corruption in hierarchies}

Lui (1986) considers dynamic models of corruption and inclusion of deterrence as a factor of reducing corruption or confining it within the certain limits. One of the means of deterrence as well as control is collection of compromat, i.e. materials or information, evidence of wrongdoing, used for allegations and accusations in illegal or immoral activities. Ideally, supervisors in organizations as hierarchical structures monitor agents and control their behavior in order to prevent potential acts of corruption. However, corruption may develop vertically across the levels in an organizational hierarchy. Carillo (2000, p. 3) notes: "But corruption can propagate within the hierarchy. We capture this recursive property of corruption by assuming that agents can share the bribe with their superiors in exchange for not being denounced." This presupposes existence of collusion between supervisors and agents.

Issue of collusion is addressed in Gong (2002), Khalil \& Lawarree (1993, 1995, 1996), Laffont \& Martimort (1997), Lambert-Mogiliansky (1995), Olsen \& Torsvik (1998), Strausz (1996), and Tirole (1986). These works examine collusion-proof contracts in different settings of the principal-agent frame. Principal-agent theory, first developed in economics to study relations between the owners of the enterprises and their managers, is now widely used in investigating numerous issues in public policy and may be applied to the issues of higher education corruption. Principal-agent structure is multilevel. National leader is an agent to his electorate while at the same time he is a principal to presidential administration. This hierarchy may be scaled down to the local elected and appointed officials. Principal-agent problem in the fields of public policy and 
economics is described by Banfield (1975), Becker and Stigler (1974), Darden (2002), Kunicova and Rose-Ackerman (2001), Rose-Ackerman (1975, 1978, 1999), and Solnick (1998), to name but a few.

Principals and agents are both self-interested actors, so their preferences often diverge. This agency problem not only urges a principal to monitor the agent, but also to try different mechanisms of controlling his behavior. Agent abuses his position by getting involved in corruption and by encouraging his subordinates to do the same in order to blackmail them later. Describing collective corruption Gong (2003, p. 88) says that its purpose is: "to maximize individual gains and/or minimize the risks associated with corrupt activities.” In fact, vertical hierarchy uses risk minimization as a tool for maximizing total benefits for the regime. Minimization of formal risks is an essential part of the corruption and coercion scheme.

Shleifer and Vishny (1993) investigate possible implications of centralization and decentralization of corrupt organizations on the total volume of corruption. They consider vertical structures and come to the conclusion that decentralization of corruption leads to an increase in the total volume of graft collected by corrupt bureaucrats. Problem of corruption in hierarchies is researched by Bac $(1996,1998,2001)$, Olsen \& Torsvik (1998), and Varian (1990). Corruption in hierarchies is studied in connection with the principal-agent theory. Olsen \& Torsvik (1998) combine the principal-agent theory and issues of collusion by considering collusion in organizations within the principal-agent frame. Guriev (2003) considers three-tier hierarchies with principal, bureaucrat, and agents. Carillo (2000) develops four-tier hierarchical model that includes corrupt behavior. Waite and Allen (2003) make an attempt to follow the possible top-down and 
bottom-up channels of conveying benefits of corruption as well as resources in educational systems.

Another part of studying corrupt hierarchies in organizations is the cost-benefit analysis used in designing cost-effective models and mechanisms of supervision. Bac (1998) investigates the problem of organizing three agents in a hierarchical monitoring structure and designing a corresponding incentive system to minimize the cost of implementing a target level of corruption. Bac $(1996,1998)$ combines hierarchies, costbenefit analysis, and collusion in potentially corrupt structures and demonstrates that the possibility of collusion may prevent the implementation of anything less than full corruption. He asserts that "In relatively flat hierarchies, economies of scale in monitoring reduce implementation costs but may increase the risk of collusion." (Bac, 1998)

Different types of hierarchies include the hierarchy where one supervisor monitors two subordinates with the supervision chain, whose upper part is shown to display a higher risk of collusion than its lower part. Different hierarchical structures are then contrasted with each other in order to follow the performance of each in terms of better supervision and control. This helps understanding possible measures to prevent corruption in organizations.

Corrupt structures in higher education have evolved from vertical to horizontal and back to vertical, depending on the region. This chapter presents vertical structure, horizontal structure, and vertical hierarchy and makes projections about their possible future developments. 


\section{Vertical structure}

Vertical structure is taken as an initial form of organizational structure with some presence of corruption. Major characteristics of the vertical structure include an absolute degree of centralization and concentration of formal authority. Bribe-takers or corruptioners have an opportunity to draw some benefits from their position without using their authority over their subordinates. They have to operate in conditions of clear laws and regulations, as well as high risk of punishment. Vertical structure anticipates a very high degree of monopolization and discretionary power. Corruptioners, positioned at the top of their organizations and institutions, enjoy a near-perfect monopoly in access to graft. The level of secrecy in vertical structures is very high, while corruption itself is not widely acknowledged. The high level of secrecy may be explained by two facts: first, corruptioners do not need broad networks of corrupt interrelations with their subordinates and so corruption is localized and confined to a small group of individuals; second, the risk of actual punishment is very high, and the degree of punishment is high as well.

The form of organization that existed under the planned economy in the USSR can be characterized as a vertical structure. The level of tolerance of corruption by coworkers, as well as by the public in general, was quite low. Corruption was considered unordinary, or extraordinary, and definitely wrong. The level of transparency was high in relation to the investigated and prosecuted cases of corruption. In 1986, the central government dismissed 13 thousand bureaucrats and economic directors and reprimanded another 100 thousand for corrupt activities, including embezzlement, fraud, and bribery (Saleh, 2003). 
The cases of corruption were addressed in governmental publications. The publications themselves were authorized by the central authorities, since all media was controlled by the state and the Party organs (McNair, 1991). Such publications were based on particular legal cases. A low level of corruption among bureaucrats was maintained by ideology and ethical standards (Ivanov, 2005). Examples of corruption presented in the Soviet media included the so-called Coal mafia and Coal investigation in Donbass (Matsuzato, 2001), as well as numerous cases of embezzlement, fraud, and speculation in the retail sector.

Corruption in higher education was disclosed in such institutions as Baku Institute of Economy (Bakinskij Institut Narodnogo Hoziajstva), Yerevan State University, and few other higher education institutions. Baku Institute of Economy was the only higher education institution in the USSR that was reorganized and renamed because of its numerous cases of corruption (Gorshkov, 2007). The special governmental commission investigating Baku Institute of Economy found rampant corruption and fraud during the investigation of entrance examinations and academic process. In Yerevan State University there were a few cases of extortion, when professors demanded bribes even from well-performing students.

The major form of corruption in the 1980s was embezzlement. One of the characteristics of this embezzlement was its grand scale. While in the retail sector there was plenty of petty corruption, in other industries corruption was relatively rare but occurred on a grand scale. The predominance of embezzlement over other forms of corruption is easy to explain. In Soviet times, dominated and indeed monopolized by the centralized systems of governance, management, control, distribution, and production 
itself, the major task for a corruptioner was embezzling from the state. The main difficulty for a corruptioner was to actually enjoy the benefits derived from corruption. The state imposed restrictions on levels of personal consumption and exercised oversight over the lifestyles of individuals. For instance, no one was allowed to own more than one car or build a two-storey private house. Access to housing was based on the number of family members and not the ability to pay. In the case of major expenditures, sources of income had to be justified by the household (Alexeev, 1988).

In the USSR, the level of corruption varied region by region. While in the Russian Federation, Ukraine, and the Baltic republics the level of everyday corruption was very small and corruption itself was confined to major cases of embezzlement and petty corruption in the retail sector, corruption was more common in the republics of the Caucasus and Central Asia, including in the areas of higher education and healthcare (Eizenbaum, 2005). The vertical structure of corrupt organization is presented in Figure 6.
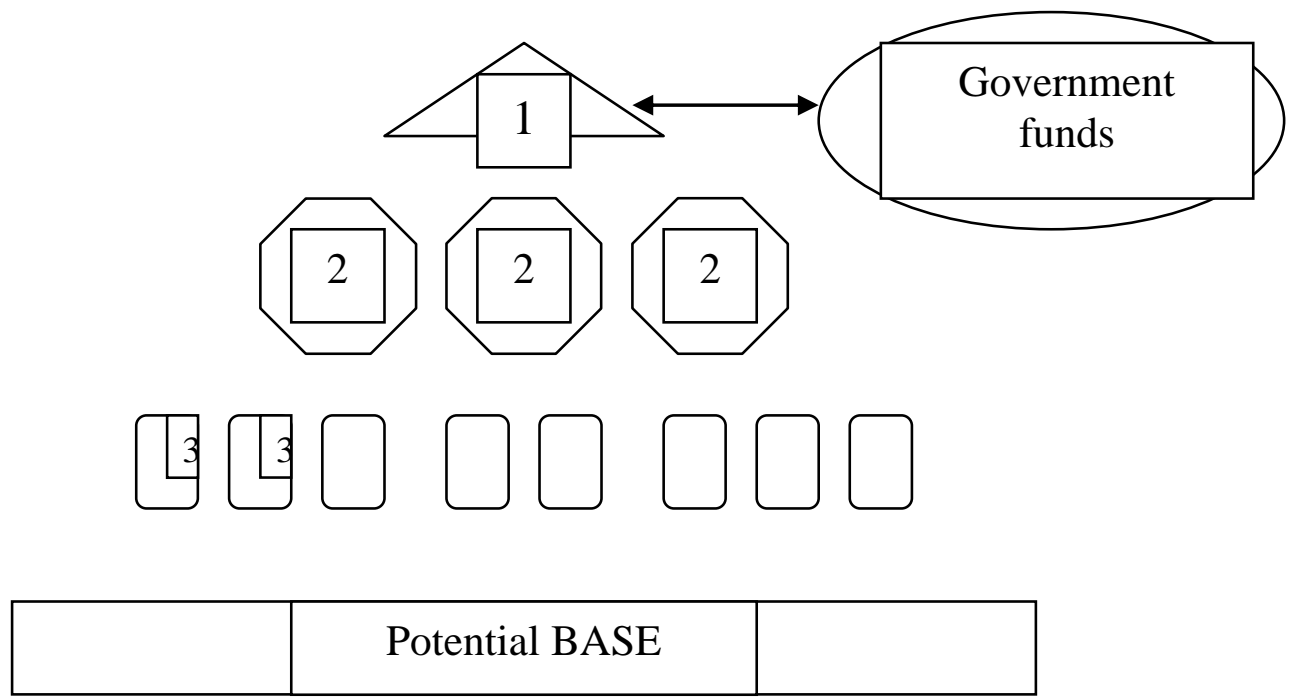

Figure 6. Vertical structure of organization with corruption 
" 1 " depicts the highest level in the organization, be it a ministry, a directorate, or other managerial unit, depending on the unit of analysis. "2" depicts the second level in an organization, i.e. mid-management. Employees at the lowest level of the hierarchical ladder are marked with " 3. ”

Understanding the vertical structure of corrupt organizations might shed some light on how corruption takes place in higher education institutions, e.g. embezzlement from state funds by the rectorate, the university president's office. This type of corruption is similar to that in other organizations funded by the government. Embezzlement of funds was rare, while embezzlement of products was more common. A good example would be a director of a collective farm (kolhoz or sovhoz) who funded construction of a new school in his district, while building a private house in a neighboring district. He would use construction materials taken from the school construction site.

\section{Transition from vertical structure to horizontal structure}

The period of the late 1980s and early 1990s in the USSR was characterized by Perestroika, the movement for independence in the republics and for market reforms. Government funding was declining and consequently the total base for embezzlement was shrinking. The state funding of higher education in the Russian Federation fell during the period of 1992 to 1998 at an average annual rate of 19.6 percent (Kniazev, 2002, p. 111). In Azerbaijan, public spending on education by 1997 was 34 percent of its level in 1992 (Petrov and Temple, 2004). Parallel structures were created in order to generate extra income, including that coming from corrupt activities. Parallel structures were also 
intended to increase the rate of embezzlement in order to compensate for the potential losses due to the shrinking base, i.e. declining government funding.

It is important to note that the creation of parallel structures in higher education in order to generate extra income was not caused by the decline in funding from the central budget, but by the relative independence and openness and newly emerging opportunities for selling educational services to match excessive demand. All of these were created shortly before the budget cuts. Those who created the parallel structures identified within the base a separate segment from which to draw benefits in exchange for educational services. Here the general structure stays intact. A vertical structure that incorporates parallel structure in a corrupt organization is presented in Figure 7.



Figure 7. Parallel structure in a corrupt organization with the vertical structure

Examples of parallel structures created to ease modes of embezzlement and create new venues for corruption are numerous. Private or so-called commercial banks were created within large state enterprises. They paralleled state banks in issuing credits to the 
enterprises by which they were created. Playing on the difference in the interest rates, top management of state enterprises accumulated significant funds necessary for the future privatization of these enterprises (Blasi, 1996).

The Ministry of Science and Education established an autonomous unit to conduct licensing and accreditation of newly emerging private higher education institutions. This department, created under the auspices of the Ministry of Education, was based on the principle of hozraschet, i.e. self-financing. In public opinion the term hozraschet was closely associated with the term "corruption."

For-tuition programs were created within the departments that provided educational services in the majors in high demand, including economics, finance, and law. By the year 2002, 54 percent of students paid for their education, while 46 percent were paid by the federal government and local administrations. It may also be true that the majority of students had to pay a bribe or to be involved in other forms of corruption during their courses of study (Smolentseva, 2002).

Private or so-called commercial higher education institutions were created by those who earlier led for-tuition programs in public universities. Licensing, accreditation, and programs for working adults were riddled with corruption. The low quality of education and degrees being conferred in exchange for tuition is an example of corruption in parallel structures. Parallel structures enjoyed a low level of direct governmental control.

In public higher education institutions, branches were created in order to maximize income. The quality of educational programs in these branches has been relatively poor. Poor quality translates into corruption, because the degrees conferred are 
no different from those conferred by the head institutions and money is taken in the form of tuition and fees, as well as informal payments. The normal process of institutional outreach suffers from corruption. Along with well-established public universities, branches are also created by private higher education institutions in order to maximize total revenue. The quality of educational programs here is often poor as well, while tuition and fees are supplemented by collective and individual informal payments.

In Kazakhstan and Central Asia more abuse took place during the establishment and operation of branches of public and private higher education institutions than in the Russian Federation and Ukraine. Some private higher education institutions and branches of public higher education institutions in the region are but ghosts, existing only on paper, much like the US diploma mills. Others only employ visiting faculty from the head campuses and classes are not held regularly. In Georgia, a country of around 3 million people, the number of higher education institutions is disproportionately large for the region and is several times higher than it was before independence in 1991. There were around 200 higher education institutions in Georgia in 2007, as compared to 535 in Ukraine, which has a population of 50 million, and 1068 in the Russian Federation, with its population of 148 million. This indicates potential problems with the quality of education in some of the so-called higher education institutions in Georgia (Ministry of Education and Science of Ukraine, 2007; Ministry of Education and Science of the Russian Federation, 2007).

Relatively close control over the system of higher education by the government in Ukraine, even during the "liberal" 1990s, prevented, to a high degree, the rise of corruption in branches and consequently precluded the sharp decline in the industry that 
would take place in some other republics starting in the late 2000s. While in the Russian Federation some of the private colleges and their branches are slowly disappearing, in Ukraine such a process is virtually non-existent.

The key phrase that describes the period of transition from a vertical to a horizontal structure is "They want to eat and we do not," as related to the higher-ups. This is a sarcastic phrase used by subordinates when referring to what motivates the actions of underpaid public servants, be it bureaucrats or faculty members, and their higher-ups. Centralized corruption, with its near-perfect level of monopolization of access to graft, no longer satisfies the majority of the employees, including the faculty and staff of higher education institutions.

\section{Horizontal structure}

One of the major characteristics of the horizontal structure is that it develops through a process of decentralization and of declining concentration of formal authority. Other major characteristics include low salaries for employees and their opportunistic behavior.

Conditions in which horizontal structures form and operate include the absence of clear laws and regulations, low risk of actual punishment, and prioritization of financial survival by organizations, as well as by individuals. The degree of monopolization and discretionary power in horizontal structures is low as compared to vertical structures. Horizontal structures are less secretive. Even though corruptioners do not share the information, everyone knows that just about everyone accepts bribes and gifts or enjoys 
other benefits of corruption. The existence of corrupt practices is widely acknowledged by the employees as well as by the general public. This situation is traditionally described as similar to sex in Victorian times, when "everyone does it but no one talks about it." In higher education institutions faculty members know of each other's corrupt activities but do not discuss them. Such a situation can be identified as a circle of silence.

Petrov and Temple (2004, p. 87) describe this problem in higher education systems in the Russian Federation and Azerbaijan by noting the following: "Our own experiences in our region of study suggest that even the most carefully phrased enquiry to university members of staff about the existence of corruption in their institution can be taken as a personal insult. This naturally limits the scope of data collection. Students and former university staff members have no difficulty generally in discussing the matter, however." Here internal institutional silence is counteracted with the relatively high external openness to discussions.

The level of tolerance of informal payments in horizontal structures is high, as corruption is considered a part of everyday life. Petrov and Temple (2004, p. 92) note that "In Russia, our interviewees also despised bribery, but at the same time expressed the view that, perhaps, in the present situation, corrupt practices in higher education were inevitable." Spiridonov (2000, p. 245) concludes, based on a survey conducted in 1999, that the corruptioner was regarded as an "absolutely normal element of real life."

The level of transparency is high as well, as corruption is often highlighted in the mass media, including both official and independent sources (RBC, September 20, 2003). Publications are based on generalizations, as well as particular legal cases. Corruption in education is discussed openly in all of the former republics, including Azerbaijan (Guliev, 
2007), Armenia (Yerevan.ru, 2006), Belarus (Glebov, 2007), Kyrgyzstan (BPC, 2007), Moldova (Tudoryanu, 2007), the Russian Federation (RIA Novosti, 2004), Ukraine (Boljubash, 2006, CityNews, 2006). The key phrases that characterize horizontal structures and that are uttered in a tone that is apologetic (in both senses of the term) are as follows: "Everyone wants to eat," "We are all having hard times," "Everyone takes [bribes]."

Petrov and Temple (2004, p. 90) present the following comment: "One can in effect hear people say in Russia: it is impossible to live honestly on such a low salary this makes academics ask for and accept bribes. Corrupt practices are justified by this argument, not only by academics but also sometimes by students. Many in higher education see it as 'forced corruption', when both those who give bribes and those who take them are forced to engage in bribery because life, it is asserted, would be impossible unless rules were broken." Uncovered cynicism in the state's, as well as the faculty's, conduct is obvious (Sandgren, 2002).

In horizontal structures, most of the benefits from corruption are generated by each corruptioner individually and independently. The distribution of access to graft is based on such characteristics as rank and position. Rent-seeking behavior is commonplace. Horizontal structures in higher education institutions in the former USSR are characteristic of the period from the early 1990s to the present. This is a part of postSoviet reality in the spheres of higher education and healthcare.

Major forms of corruption present in horizontal structures are bribes, as well as numerous latent forms of corruption, including nepotism, favoritism, exchange of favors, services, etc. All the forms are shaped by the process of adaptation to new realities. The 
scale of corruption runs the full spectrum and varies from petty corruption to grand scale corruption, depending on the rank of the bureaucrat, his personal characteristics, etc. The horizontal structure is presented in Figure 8. It reminds one of a house-like structure, with a parallel structure as an attachment, rather than a pyramidal structure.

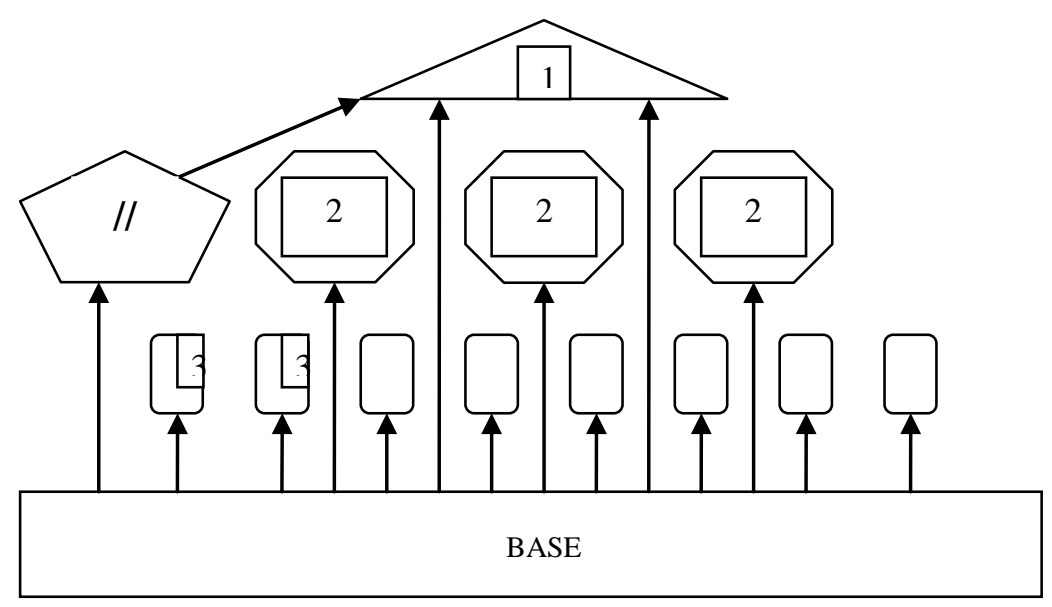

Figure 8. Horizontal structure with the parallel attachment

\section{Transition from horizontal structure to vertical hierarchy}

The transition from horizontal structure to vertical hierarchy in different industries and different regions of the former USSR has taken place in different periods. In some of the former Republics such a transition occurred starting in the early 2000s, while in others it has not yet occurred in higher education. The key phrase that captures what occurs during such a period is: "We do have corruption, but no one talks about it." At this point corruption in higher education reaches high levels. The 2000 federal budget allocated $\$ 2.5$ billion for education (Sergeev, 2002). Referring to Kostikov (2002), and 
Milkus (2002), Petrov and Temple (2004, p. 89) assert that Russian citizens pay annually up to $\$ 520$ million in bribes for admission to higher education institutions as a part of a "shadow economy" that may go as high as $\$ 5$ billion annually, "mostly in the form of perfectly legal payments for private tutoring or for various preparatory classes to help students enter higher education." Almost a third of all families in Russia hire private tutors for their children graduating from high school (Bondarev, 2002).

\section{Vertical hierarchy}

Vertical hierarchy anticipates both formal and informal subordination. Its major characteristics are an absolute degree of centralization and a concentration of formal and informal authority. Conditions for vertical hierarchy include unclear laws and regulations, as well as high risk of punishment for opposing illegal practices rather than for violating formal rules. The degree of monopolization and discretionary power is high. There is a near-perfect monopoly in access to graft.

Vertical hierarchies are highly secretive, but the presence of corruption is widely acknowledged. The high level of internal secrecy is explained in part by the presence of a developed net of corrupt relations through which corrupt practices are performed and the benefits of corruption channeled. The level of tolerance of corruption is high, with corruption accepted as a norm. Transparency is limited to formally approved governmental publications. Vertical hierarchy is characterized by silence because of the fear of being reprimanded or dismissed. 
It would be difficult to single out just one form of corruption as the major form, since many forms of corruption are present, including embezzlement, fraud, and bribes, as well as numerous latent forms of corruption, such as nepotism, favoritism, exchange of favors, exchange of services, etc. Vertical hierarchy is characterized by the continuous invention and formalization of new forms and mechanisms of corruption, in addition to those inherited from the horizontal structure. The preferred form of corruption may be bribes in cash, since part of the illegal benefit is supposed to be channeled to the higherups. Natural exchange is replaced by the monetary exchange. All services and favors have a clearly defined monetary value.

The scale of corruption in the vertical hierarchy is more significant than in the vertical structure and the horizontal structure. All levels of corruption are present, ranging from petty to grand corruption. The large scale of corruption is explained by the dominance of the process of maximization of the total amount of illegal benefits derived from corrupt activities.

The vertical hierarchies developed in the early 2000s in some of the former Soviet republics, when the major task for a corruptioner became maximization of total corrupt benefits based on sharing and profiteering. Vertical hierarchy may often be mixed with collective corruption and collusion. Vertical hierarchy uses risk minimization as a tool for maximizing total benefits.

Vertical hierarchy is the highest organizational level of corruption, where corruption is institutionalized or near-institutionalized and is the result of collective effort. This level is characterized by the delegation of corrupt functions to subordinates. Sharing and profiteering are the two dominating features of the participants and the structure 
overall. Subordinates collect bribes and then channel benefits up the hierarchical ladder. At this stage the top becomes a good "roof" or an "umbrella" for the entire corrupt structure, protecting it from a possible negative external impact. Petrov and Temple (2004, p. 87) point to routinization of corruption in higher education and to the fact that bribes are sometimes referred to as informal fees. The authors believe that, at this point, the rates are largely predetermined and that corruption acquires a semi-public character.

There are numerous records and research statements that public offices are on sale and profitable or that bread-winning places are bought-out (Gong, 1997, 2002; Gorha, 2000; He, 2000). In the vertical hierarchy, a lump sum payment is often required to receive a position in a corrupt organization (Gong, 1997, 2002). Such a practice also guarantees that the new employee accepts the informal rules of the vertical hierarchy and will cooperate and share the benefits of corruption with the top. Accordingly, if a potential candidate refuses to make an advance lump sum payment, it means that he is likely not to conform to the rules of the vertical hierarchy, and hence he is denied access to the organization. The lump sum payment may also be made after the employment during which a sufficient amount of money needed to make the payment can be earned and accumulated, often referred to as establishing a "credit line." This broadly accepted practice is similar to that used in human trafficking and other illegal businesses. Sometimes this type of career path starts from the time of one's education. For instance, in order to enter a police academy one has to pay a lump sum bribe. He then makes his money back by accepting informal payments (Newsru.com, 2006, 2007). Joining the traffic police after graduating from the police academy also costs money. By the time an 
individual joins the vertical hierarchy he is already well-educated about the corrupt practices and ready to take part in them.

The practice of paying bribes for entering a faculty position in higher education is not widespread. Nepotism and favoritism play a certain role in hiring decisions, but the quality of every applicant is still one of the major factors considered during the decisionmaking stage of the hiring process. However, if the vertical hierarchy is to develop in the higher education industry, a lump sum payment for a faculty position may be required in order, above all, to prove future compliance with the informal rules and corrupt practices. The pyramid-like structure of the vertical hierarchy is presented in Figure 9.

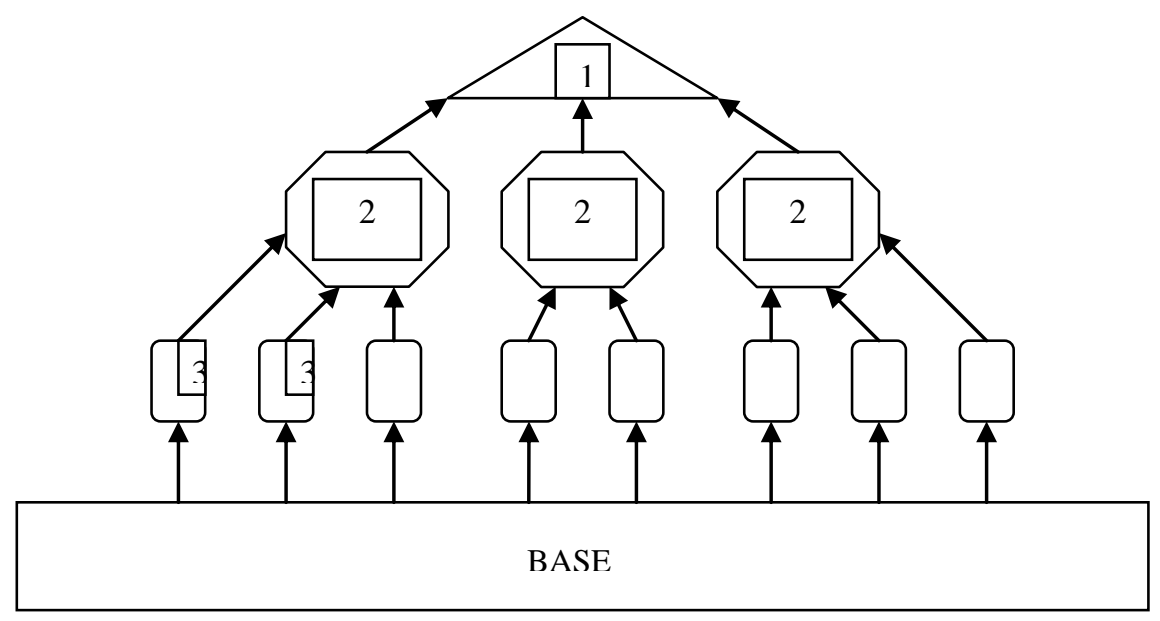

Figure 9. Pyramid-like structure of the vertical hierarchy

In this case subordinates retain some of the benefits from corruption, while giving the rest part to those at the top. This process of sharing is administered through several links in the hierarchical chain until it reaches the top. The share can be either a fixed amount of money or a percentage. Some speculations about the presence of such a 
structure in some higher education institutions in the Russian Federation are already present in the media (Gorshkov, 2005). The high density pyramidal structure of the vertical hierarchy is presented in Figure 10.

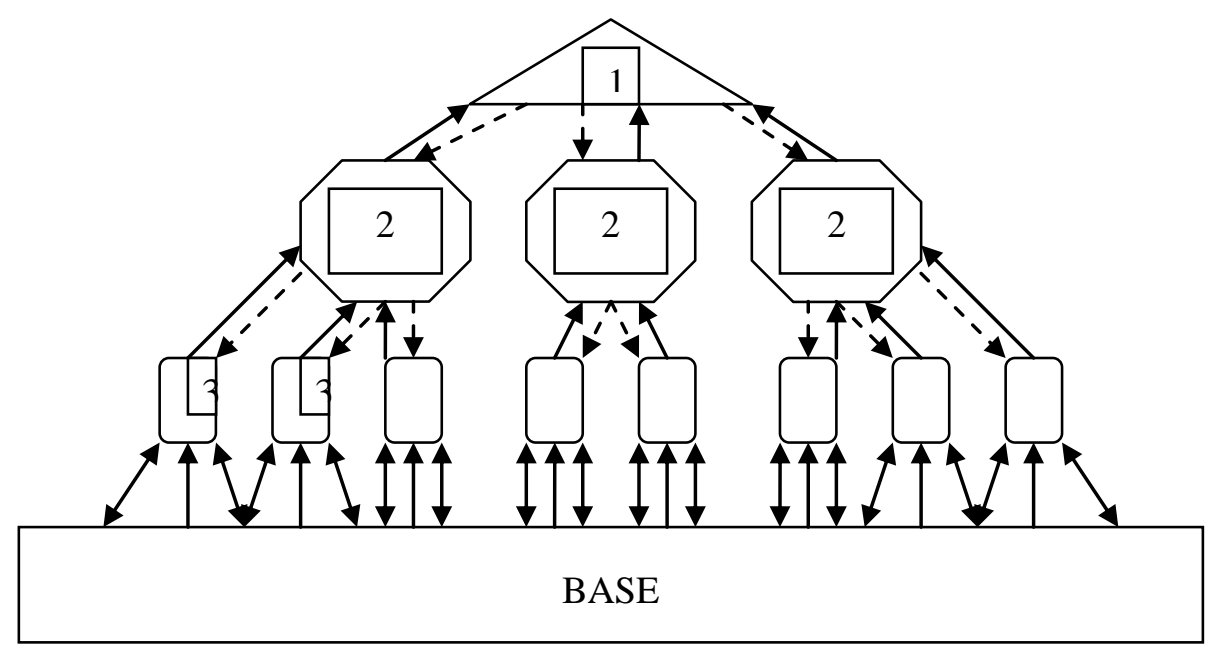

Figure 10. High-density pyramidal structure of the vertical hierarchy

The dashed arrows in Figure 10 represent paybacks from the top to the immediate subordinates. In this case, the top collects all the benefits of corruption and then distributes part of them among the subordinates. Here subordinates are no longer partners in the illegal activities but rather mere tools. They are instrumental in collecting graft. Other variations in the distribution of graft in vertical hierarchies are possible. At this point, informal operations of the vertical hierarchy are no different from the formal business-like operations of corporate structures, where revenue is collected by the company and then distributed in form of wages and bonuses.

The double-ended arrows in Figure 10 symbolize extortion. Agents attempt to maximize their benefits by maximizing total amount of graft derived from the base by 
using all variety of possible tools and mechanisms, including extortion. Extortion as an openly presented demand for a bribe in exchange for a certain service, such as permission, license, admission, and positive grades, was rarely practiced in higher education during the Soviet era. Extortion can be of at least two types. First, extortion anticipates an informal payment which would not be made otherwise. Second, extortion may anticipate an informal payment of a larger size than would be made otherwise. Petrov and Temple (2004, p. 90) note that, in distinction with "morally justified" corruption in Russia, in Azerbaijan students tend to see themselves as victims of extortion. Apparently, in Azerbaijan, as well as other former Soviet republics in the Caucasus and Central Asia, horizontal structures move toward vertical hierarchies.

Higher education is somewhat similar to healthcare but differs significantly from other industries. Higher education is still archaic, as related to corruption. The reasons for that are as follows: first, higher education preserves high moral and ethical standards of conduct and a sense of collegiality; second, it has a double-directed hierarchy of administrative position and academic merit; third, there are no pure market-based relations and market-type mechanisms in the industry, i.e. higher education has yet to be fully commoditized. One may anticipate a relatively low level of collusion among the faculty members as related to sharing the benefits of corruption that exist in form of bribes, yet a very high level of collusion as related to exchange of favors and other forms of latent corruption. The three major types of corrupt structures discussed above are presented in Table 4. 
Table 4

Structural forms of organization of corruption and their major characteristics in higher education

\begin{tabular}{|c|c|c|c|}
\hline Indicators & Vertical structure & $\begin{array}{l}\text { Horizontal } \\
\text { structure }\end{array}$ & Vertical hierarchy \\
\hline Characteristics & $\begin{array}{l}\text { Absolute degree of } \\
\text { centralization and } \\
\text { concentration of } \\
\text { formal authority }\end{array}$ & $\begin{array}{l}\text { Decentralization, } \\
\text { reduced } \\
\text { concentration of } \\
\text { formal authority, } \\
\text { low compensation, } \\
\text { opportunistic } \\
\text { behavior }\end{array}$ & $\begin{array}{l}\text { Absolute degree of } \\
\text { centralization and } \\
\text { concentration of } \\
\text { formal and } \\
\text { informal authority }\end{array}$ \\
\hline Conditions & $\begin{array}{l}\text { Clear laws and } \\
\text { regulations, high } \\
\text { risk of } \\
\text { punishment, } \\
\text { centralized } \\
\text { funding }\end{array}$ & $\begin{array}{l}\text { Absence of clear } \\
\text { laws and } \\
\text { regulations, low } \\
\text { risk of punishment, } \\
\text { financial survival }\end{array}$ & $\begin{array}{l}\text { Unclear and } \\
\text { contradictory laws } \\
\text { and regulations, } \\
\text { high risk of } \\
\text { punishment for } \\
\text { nonconformity }\end{array}$ \\
\hline $\begin{array}{l}\text { Degree of } \\
\text { monopolization }\end{array}$ & $\begin{array}{l}\text { Very high, near- } \\
\text { perfect monopoly }\end{array}$ & Low & $\begin{array}{l}\text { High, near-perfect } \\
\text { monopoly }\end{array}$ \\
\hline Discretionary power & High, centralized & Decentralized & High, centralized \\
\hline Level of secrecy & $\begin{array}{l}\text { Highly secretive, } \\
\text { not widely } \\
\text { acknowledged }\end{array}$ & $\begin{array}{l}\text { Less secretive, } \\
\text { widely } \\
\text { acknowledged }\end{array}$ & $\begin{array}{l}\text { Highly secretive, } \\
\text { but widely } \\
\text { acknowledged }\end{array}$ \\
\hline Level of tolerance & Low & High & $\begin{array}{l}\text { High, accepted as } \\
\text { a norm }\end{array}$ \\
\hline Level of transparency & $\begin{array}{l}\text { Governmental } \\
\text { publications in the } \\
\text { media }\end{array}$ & $\begin{array}{l}\text { Mass media, both } \\
\text { official and } \\
\text { independent }\end{array}$ & $\begin{array}{l}\text { Governmental } \\
\text { publications in the } \\
\text { media }\end{array}$ \\
\hline Major form & Embezzlement & $\begin{array}{l}\text { Bribes as well as } \\
\text { latent corruption }\end{array}$ & $\begin{array}{l}\text { All existing forms, } \\
\text { invention of new } \\
\text { forms }\end{array}$ \\
\hline Scale & Grand corruption & $\begin{array}{l}\text { Full range, from } \\
\text { petty to grand } \\
\text { corruption }\end{array}$ & $\begin{array}{l}\text { Full range, } \\
\text { maximization of } \\
\text { total illegal } \\
\text { revenue }\end{array}$ \\
\hline Period & Soviet times & Post-Soviet & Post-Soviet, 2000s \\
\hline
\end{tabular}

Source: Completed by the author 
None of the forms is free of problems and internal conflicts. There are certain immanent and developing problems and antagonisms in each of the organizational structures. These antagonisms, as well as changes in external environment, push the structures to adjust and move to the next stage.

The vertical structures can only last as long as there is absolute power concentrated at the top and all the subordinates have a satisfactory level of income. As related to higher education institutions, faculty and administrators will only tolerate exclusiveness of access to graft limited to top management or the rectorate as long as their legal income is high enough to provide them with living standards and the social status allotted to them by the society. Once their level of income suffers significant decline without the prospect of fast recovery, they present their claims to part of the "pie" and start seeking other sources of income inside as well as outside of academia. Collecting informal payments at their full-time teaching positions, as well as part-time positions, becomes a norm. Centralized control, the top-down approach, administrative tools and artificially imposed restrictions become ineffective in reducing corruption.

The vertical structure transforms into horizontal structure with its freedom, equality, and Bentham's logic. Opportunities in access to graft are distributed amongst all, but they are not distributed equally. Initially, the top level dominates. Later, however, it becomes disadvantaged. A large portion of graft goes to those in direct contact with the base. The number of students directly relates to amount of graft collected. This disadvantage is eliminated promptly. The faculty members with limited teaching loads due to administrative duties collect benefits from the students by utilizing their administrative authority. The faculty members are called to sign some of the students' 
record books in the chair's office or dean's office or other administrative offices. This gives them informal approval of collecting bribes in exchange for grades. The faculty members, academic offices, and administrative offices compete for the students' informal payments. The delineation of functions is unclear and so offices and faculty members may give attestation to a student interchangeably.

The top starts seeking ways to channel benefits of corruption from the lower level or the "frontline" to the top. The justification for such motion is threefold: first, it is done under the slogan of fighting corruption within the institution; second, it is conducted as a part of a larger anti-corruption campaign, demanded by the central authorities; third, quality of education and graduates as a part of the institution's reputation must be reclaimed. In essence, the top attempts to re-monopolize its access to graft and other benefits of corruption, improve the image or facade of the institution, and report achieved success to the central authorities.

This creates at least three possible forms of future organization, including a return to the modified vertical structure, the formation of a hybrid or the mixed structure, or the creation of a vertical hierarchy. Evolution and possible options in corrupt organizational structures in higher education can be presented as follows: 


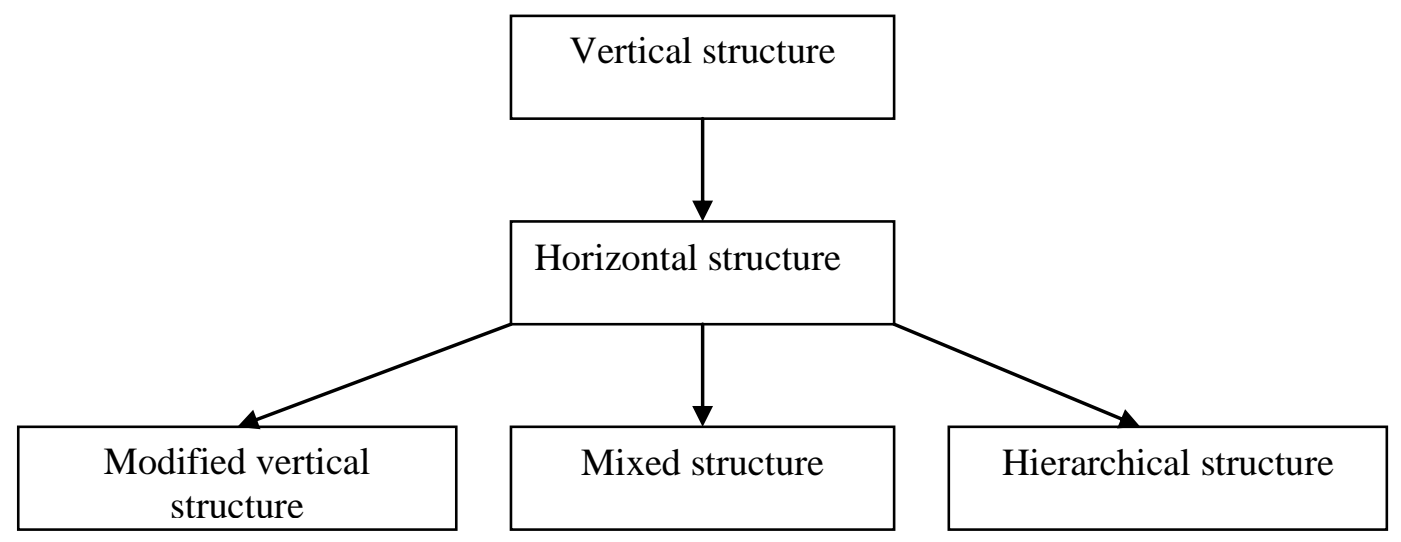

Figure 11. Evolution and possible options in corrupt organizational structures

The vertical structure and the vertical hierarchy are described above. Mixed structure as a likely option of predominant corrupt organizational structure in higher education combines elements of both horizontal and vertical structures with the core exchanges having the form of latent corruption. In the mixed structures benefits of corruption are derived without being served by the monetary exchange. In higher education institutions characterized as mixed structures, faculty members distribute access to publicly funded places among themselves. Access and student retention are shared and maintained on the collegiate basis, when faculty members agree on admission decisions and positive grades for students. Additional revenue is generated from the fortuition programs.

Mixed structures are relatively democratic, with a high level of equality in access to benefits of corruption. Total amount of corrupt benefits depends on the rank and position of each faculty member. A top level faculty who is also positioned at a key administrative role has access to a larger number of publicly funded places and controls not only student admission and retention, but faculty hiring and retention as well. The 
central authorities are satisfied with the mixed structure, since it presents a relatively low level of open corruption, while the predominant latent corruption is difficult to detect. The state maintains an official image of high integrity in higher education (Filippov, 2001, Mustafayev, 2002).

The three key questions are: What stage has the higher education industry or particular higher education institutions in each of the regions of the former Soviet Bloc reached? Can horizontal structure be considered as a steady state? Where is it moving, toward what structure?

The modified vertical structure is centralized. However, in distinction from the vertical structure, it is market-based, and students pay for access to educational services. Similar to the vertical structure, there is little corruption in the modified vertical structure. Most of the payments are legal. Revenues are shared in form of high salaries. The administration fights corruption in order to channel all types of income into a formal stream of tuition payments. The administrators are highly paid. However, faculty members demonstrate some opportunistic behavior. Bribes are rare and risk of punishment for unauthorized corrupt activities is high. The modified vertical structure is only viable if the administration shares the revenue and pays high salaries to the employees.

Mixed structures combine for-tuition programs and government funded programs. In the modified structures for-tuition programs experience the same problems as in the modified vertical structures. State-funded places in the mixed structures are distributed among the faculty members. Higher education institutions are converted into family enterprises. There is virtually no cash flow present in informal transactions. Shares of 
faculty members in access to graft and other benefits of corruption differ and are not clearly specified. Informal authority lacks clear demarcation. This creates a ground for continuing conflict. Also, faculty members who do not place their children, grandchildren, nephews, and protégés to the higher education institution are less cooperative as they prefer monetary and non-monetary benefits. This touches upon those faculty members who have their relatives and protégés in the higher education institution. Obviously, monetary exchange is the most market-like form of corruption, while the mixed structure gives way to latent forms of corruption.

Strengthening of latent forms of corruption goes in contradiction with the market reforms. Such conflict is amplified by the fact that the two forms-for-tuition programs and government-funded programs — not only coexist in one institution but are virtually indivisible. Faculty members teach in both types of programs while students are often mixed and are not separated by groups. In the vertical hierarchies the major conflict forms around the determination of shares in access to graft as well as distribution and redistribution of the benefits obtained from corrupt activities.

\section{Conclusion}

This chapter identifies three major organizational structures with corruption, including the vertical structure, the horizontal structure, and the vertical hierarchy. The criteria selected include major characteristics, conditions or environment, degree of monopolization and distribution of discretionary power, levels of secrecy, tolerance, and transparency, predominant forms and scale. Vertical structure is taken as an initial form 
of organizational structure with some presence of corruption. Major characteristics of the vertical structure include absolute degree of centralization and concentration of formal authority. Corruptioners have an opportunity to draw some benefits from their position without using their authority over their subordinates. Collusion did not take place in the structure itself. The major form of corruption at that time was embezzlement when corruptioner was embezzling from the state. Usage of the embezzled funds required a certain form of external collusion.

Vertical structure transformed into horizontal structure. Major characteristics of the horizontal structure are that it exists and develops along the lines of the process of decentralization, and declining concentration of formal authority. The characteristics also include low salaries of the employees and their opportunistic behavior. The horizontal structure may potentially transform into the vertical hierarchy. Vertical hierarchy anticipates both formal and informal subordination. Major characteristics are absolute degree of centralization and concentration of formal and informal authority. Conditions for vertical hierarchy include unclear laws and regulations, and high risk of punishment for opposing illegal practices rather than for violating formal rules. Vertical hierarchy is the highest organizational level of corruption when corruption is institutionalized or nearinstitutionalized. This level is characterized by the delegation of corrupt functions to subordinates. Sharing and profiteering are the two dominating functions of the participants and the structure overall. Subordinates collect bribes and then channel benefits up the hierarchical ladder.

Each of the forms is not free of problems and internal conflicts. There are certain immanent and developing problems and antagonisms in each of the organizational 
structures. These antagonisms as well as changes in external environment push the structures to adjust and move to the next stage. In the vertical hierarchies the major conflict forms around the determination of shares in access to graft as well as distribution and redistribution of the benefits obtained from corrupt activities. Parallel structures were created in order to generate extra income, including that coming from corrupt activities. Parallel structures were also intended to increase the rate of embezzlement in order to compensate for the potential losses due to the shrinking base, i.e. declining government funding. In horizontal structures most of the benefits from corruption are generated by each corruptioner individually and independently. Distribution of access to graft is based on such characteristics as rank and position. Rent-seeking behavior is commonplace. Level of collusion between faculty members and administrators is very low.

Higher education is still somewhat archaic as related to corruption. Higher education preserves to a certain extent high moral and ethical standards of conduct and sense of collegiality, it has double-directed hierarchy of administrative position and academic merit, there are no pure market-based relations and market-type mechanisms in the industry, i.e. higher education has yet to be commoditized. This creates at least three possible forms of future organization of corruption, including the return to the modified vertical structure, formation of a hybrid or the mixed structure, and creation of the vertical hierarchy.

Mixed structure as a likely option of predominant corrupt organizational structure in higher education combines elements of both horizontal and vertical structures with the core exchanges having form of latent corruption. In the mixed structures benefits of corruption are derived without being served by the monetary exchange. Mixed structures 
combine for-tuition programs and government funded programs. In the modified structures for-tuition programs experience same problems as in the modified vertical structures. State-funded places in the mixed structures are distributed among the faculty members. Higher education institutions are converted into family enterprises. 


\section{CHAPTER V}

\section{CORRUPTION IN HIGHER EDUCAITON}

AS A TOOL OF ADMINISTRATIVE CONTROL

\section{Introduction}

A substantial block of literature considers excessive corruption as an indication of the weakness of the government. However, opposite may well be true. In non-democratic societies, corruption, informally approved, imposed, or regulated by public authorities, is an indicator of the power of the state, rather than its weakness. This chapter argues that corruption is used on a systematic basis as a mechanism of direct and indirect administrative control and redistribution of wealth on the state level and down to local authorities and administrations of public and private institutions. Control and redistribution of wealth in this case are based on blackmail and selective justice.

Informal approval of corrupt activities in exchange for loyalty and compliance with the regime is broadly used in many countries. Legal traps are often created by the regime in order to encourage bureaucrats and entrepreneurs to violate the law and enforce them to comply and share revenues. Vertical and horizontal structures of corrupt control allow ruling regimes to sustain themselves and exercise coercive power over their constituents. Administrations of enterprises and institutions are targeted by the central and local governments in pursue of higher degrees of control. Corrupt administrators, managers, entire institutions, and regular individuals are much easier to be ruled if corrupt. 
The goal of this chapter is to discover the net of interrelations between the state and higher education institutions based on corruption as a mechanism of administrative control. This chapter first presents field-oriented definitions of corruption that exist in different areas of the research. It then describes the concept of corruption as a mechanism of administrative control. Once conceptual framework is developed, four theoretical frames are applied to analyze the issue. One of the frameworks is taken from the organizational theory and the other three from public policy theory. Organizational theory consists of the four sub-frameworks, including structural, political, human relations, and symbolic frames. These frameworks, along with the principle of economic rationality, are incorporated in the theories of vertical structure of control and horizontal structure of control. Principal-agent theory is also used to investigate relation between corrupt authorities and universities. Utilizing several theories allows avoiding biasness in developing the argument.

A simple model is developed to support the findings within the theoretical frames. Both vertical and horizontal structures of administrative control are presented and inference is drawn for higher education. This chapter specifies basic conditions of compliance and non-compliance of different groups of population with the regime, and explains how corrupt regimes maximize their position in terms of loyalty, compliance, and control.

Implications for higher education are presented in the second part of this chapter. Higher education as an industry and universities as institutions or entities have certain essential features, uncommon for the other industries and institutions, and hence theoretical frameworks are adjusted to capture the specifics of higher education. Universities concentrate academic elite of the society, set agenda for education, including its political and ideological aspects, direct students, and represent substantial voting body of the population. 


\section{Concept of corruption and coercion}

Suppressed university autonomy and pseudo accountability are often used by the state to impose its will on faculty and control the agenda of the universities. Liability and compliance of university faculty and administration is of a key importance for the regime. Faculty members are fist placed in conditions that encourage engaging in corrupt activities and then indirectly blackmailed to comply. This mechanism of informal control then expands countrywide and exists on multiple levels.

University autonomy, financial independence, and federal and state accountability of the US public universities are used to project on corrupt higher education institutions in nondemocratic regimes. Systems of higher education of the countries of the former Soviet Bloc are used as an object for analyzing the relations between the state and universities in non-democratic regimes. Time frame includes 1990-2013 with some references to earlier periods. This period is chosen as reflecting richness of contemporary events in changing environments of higher education and political structures of the countries in transition.

Drawing from historical analogies, the chapter explains phenomenon of the "second," i.e. illegal, salary as a result of an authorized rent-seeking behavior. Along with the level of compliance, the process and the level of sharing, i.e. redistribution of bribes and other benefits obtained from corrupt activities is an indicator of strength of the vertical hierarchy. This chapter makes a distinction between institutionalized corruption and institutionalized redistribution of wealth, accumulated from bribes. It argues that in higher education institutions institutionalized 
corruption is presented by distribution of corrupt functions and sources of illegal benefits, but often does not lead to redistribution of bribes along the vertical axis of control.

Zhdanov (2001) presents the following view on relation of state to corruption:

"Corruption and government are eternal antagonists. Corruption, as a form of social corrosion, “eats away" at governmental structures, while governmental authority in turn strives to destroy corruption." We argue the opposite based on Darden's (2002, p. 2) definition of the state "as a compulsory rule-making organization that is sustained through the extraction of wealth from within its territorial domain." This definition is particularly convenient in investigating powerwealth relations in non-democratic regimes. Darden (2002, p. 5) describes vulnerability of the assets acquired by illegal ways and mechanism by which the government officials subordinate their lower-level counterparts: "Hence, the threat of exposing and enforcing his wrongdoing constitutes an enormously powerful sanction and places lower-level officials in an especially vulnerable position. The severity of this sanction allows the state leadership to practice a systematic form of blackmail, with payment exacted not in cash but in obedience." This chapter develops the concept of corruption and coercion and applies it to higher education.

The practice of making people guilty and blackmailing them is not new. The scheme is very simple and may be formulated as follows: "Make people feel guilty and propose them salvage in exchange of obedience". This approach to the governance was highlighted earlier by Andreski $(1966,1968)$ in his works "Parasitism and Subversion" and "Kleptocracy or Corruption as a System of Government,” Banfield (1975), and more recently by Darden (2001, 2003).

Stability of the country does not necessarily mean low level of corruption but rather a well-adjusted mechanism of functioning of all levels of authority, even if these authorities are corrupt. Shlapentokh (2003, p. 158) asserts that "When life in a country is relatively stable, 
corruption, like some cancers, destroys a society form the inside without producing symptoms or even pain. This is the case for Putin's Russia, where the political arena is calm in comparison to Yeltsin's turbulent years in office." He says that widespread corruption creates a parallel, semifeudal chain of command that competes with the official hierarchy. In fact, this semi-feudal structure is not parallel, but is in the essence of the system. It is informal, but it does not compete with the official hierarchy. This structure is developed and maintained by the frame of formal state institutions. Waite and Allen (2003, p. 294) support this view of self-sustainability of corrupt regimes: "Corrupt systems are difficult, if not impossible, to challenge and change from within, especially since the power operant in such systems is self-protective and selfperpetuating. Also, corruption may work in tandem with other forms of repression, such as racism, sexism, and classism.” Payne (1975, p. 53) describes mechanism of subversion and corruption in national systems as well as in international politics in historical perspective, based on practices of dictatorial regimes.

The phenomenon of corruption and coercion is not a new one. It has deep roots and can be traced through the history. Russian Tsar Ioann the IV, Grozny ${ }^{1}$ (1530-1584) would be a good example. His intent to fight corruption is as famous as his greed to centralized power, control, and coercion through the terror and corruption. An interesting analog from this historical personage would be Grozny's Oprichniks and Oprichnina as a new phenomenon at the time and so-called Maski-Show ${ }^{2}$ in modern Russia, as well as Ukraine. Oprichniks were newly enlisted paramilitary who were under direct subordination to the Czar through their leader by name

\footnotetext{
${ }^{1}$ Ivan the Terrible.

${ }^{2}$ Masks-Show, when law enforcement officers wear masks in order to avoid possible retaliation.
} 
Maliuta Skuratov. These paramilitary were used to harass the old-established Council of Nobles ${ }^{3}$. Members of the Duma were targeted individually. Oprichniks normally attacked their mentions in Moscow, committing rubbery and murders. Property of murdered Nobles, including land and servants, was expropriated by the Crown. This instrument of terror worked well in coercing nobles, merchants, and population of Moscow.

Maski-Shows repeat Oprichniks. Policemen in masks who appear in offices of large corporations, small firms, political parties, mass media, NGOs, and down to the farmers' markets enforce the will of the government. They expropriate business documents and seal the premises. Business documents are used for investigation against the owners. Investigations are fabricated and represent selective justice, when firms are punished for noncompliance and refusal to share profits. Leaders of the law enforcement agencies use this instrument for their personal benefit and imposing the authority of a clan on certain entrepreneurs and corporations.

Yeltsin, being the President of the Russian Federation, advanced the point in the media that if Members of the Duma ${ }^{4}$ will be more cooperative with the Presidential Administration in forming the Cabinet of Ministers, then the administration will help them with improving their accommodations in Moscow. ${ }^{5}$

Numerous examples of informal pressure on the public officials and administrations may be found in the latest presidential elections in Russia. As Russia Journal Daily (March 16, 2004) reports: "While having successfully fulfilled the Kremlin's orders to make sure that incumbent Vladimir Putin won 70 percent, the electoral authorities, nonetheless, failed to cope with their principal task of ensuring a 70-percent turnaround. The regions that spoiled Putin's triumph may

\footnotetext{
${ }^{3}$ Boyarskaya Duma.

${ }^{4}$ the Russian Parliament.

${ }^{5}$ Pomozhem s resheniem zhilishnyh problem.
} 
face sanctions." Putin received 71.2 percent of the votes in his favor with turnout of 64.3 percent. In some regions turnout just exceeded 50 percent. By law, more than half of Russia's 109 million registered voters must cast ballots for the election to be valid. Presidential candidate Glazyev said that the heads of regional administrations familiarized their subordinates with a letter circulated by the territorial directorates of the presidential administration, obliging regional authorities to apply all administrative methods to ensure a voter turnout of no less than 70 percent and the same percentage of votes cast in favor of the incumbent president of Russia (Russia Journal Daily, 2004).

A fresh lease of power presented as democratic elections is notorious for its procedural violations. Numerous violations have been detected by the observers: "Patients at Moscow's Mental Hospital \#4 eligible to vote had received ballot papers with the box against Putin's name already ticked. Two patients wishing to cast their votes for other candidates were told that there are no other ballot papers." (Russia Journal Daily, 2004) Violations included manipulation of the lists of voters and violations related to the absentee ballots, illegal campaigning for Putin at some polling stations. Russia Journal Daily (2004) reports:

Prosecutors in Voronezh, western Russia, have uncovered a conspiracy by doctors denying medical aid to patients who refused to vote for the president. The health officials have already admitted their guilt, and claim that the regional authorities were in no way implicated in the scandal. A similar case was registered in the far-eastern city of Khabarovsk, where health officials, too, admitted they had ordered hospitals not to admit patients without absentee ballots, claiming that in doing so they were guided solely by their sense of civic duty. It transpired that an order bearing the astonishing title 'On the Medical Guarantees for the Election of the President of the Russian Federation, the Head 
of the Voronezh Regional Administration and the Organs of Local Self-government' was signed by the acting head of the regional health directorate. The document was then forwarded to all regional hospitals.

The official assumed full responsibility for the order and prosecutors said they are not planning punitive actions since there are no complaints from the patients.

Same story may be told of some higher education institutions, where classes were held on Sunday, the Election Day, and all students were then taken from classes to the ballot boxes. Prisoners and military also exercise their right to vote while the objectivity of such voting practices raises some concerns. These electoral voting practices are quite consistent with population's perceptions about corruption and corruptness of the different branches of public services and institutions, especially taken in light of the concept of corruption and coercion. Evidence from the consumer side indicates that health services are a leader in corruption, police is second most corrupted body, and college and university faculty and administration are third.

Interestingly, Putin's competitors and his criticizers did not suggest any reason why all the local administrators and directors of public and private enterprises appeared so cooperative and supportive to Putin that many of them even used informal and illegal ways of fulfilling the directive of 70 percent turnout and 70 percent votes "for". One would assume that administrative pressure alone, especially on directorates of private enterprises, is insufficient for organizing such supportive campaign.

Informal pressure here is done on a systematic basis from top to down. There is no direct evidence that different forms of coercion were in fact exercised based on corruptness of the local authorities, administrations, and directorates of businesses and state enterprises. However, presence of all three factors: 1) formal and informal vertical authoritarian pressure of central 
authorities on the regional and local authorities and directorates, 2) numerous facts of corruption on all the levels of public policy, public services, businesses, and perceptions of population about presence and tolerance of rampant corruption, and 3) numerous facts that all these administrators, directors, and public officials have demonstrated their loyalty to the ruling president and utilized different formal and informal, legal and illegal, mechanisms of fulfilling their informal obligations before the regime, may be interpreted as a ground for the concept of corruption and coercion.

Same mechanism of the state-based corruption and coercion in Ukraine is described by Zhdanov (2002, p. 5), who writes about the selective application of the criminal law and other repressive legal measures to governmental officials and politicians: "The use of juridical reprisals against political opponents by means of charging them with corruption (or other illegal acts) when there are no legal grounds to do so." Often the laws or the normative acts are composed post-ante in order to prosecute an activity that took place when it was not illegal. Legal craftsmanship is one of the essential features of the government that uses its authority for the purpose of selective justice. Political rhetoric is impressive: corrupt oppositionists claim that they are prosecuted because they are in opposition to the corrupt regime while the regime states that it opposes corrupt politicians.

\section{Principal-Agent frame}

Principal-agent theory, first developed in economics to study relations between the owners of the enterprises and their managers, is now widely used in investigating numerous issues in public policy. Principal-agent problem can clearly be observed in the countries of the 
FSU. Principal-agent structure is multilevel. National leader is an agent to his electorate while at the same time he is a principal to presidential administration. This hierarchy may be scaled down to the local elected and appointed officials. Principal-agent problem in the field of public policy and higher education is described by Banfield (1975), Becker and Stigler (1974), Darden (2002), Kunicova and Rose-Ackerman (2001), Rose-Ackerman (1975, 1978, 1999), Solnick (1998). The agency problem not only urges principal to monitor the agent, but also to try different mechanisms of controlling his behavior. Agent abuses his position by being involved in corruption and by encouraging his subordinates to do the same in order to blackmail them later. In fact, vertical hierarchy uses risk minimization as a tool for maximizing total benefits. Informal minimization of formal risks is an essential part of corruption and coercion scheme.

In China, central authorities encourage public officials and whole institutions to involve in entrepreneurial activities. Entrepreneurial activities in China are heavily corrupt. Gong (1997, p. 285) writes: “A majority of cadre entrepreneurs emerged after Deng Xiaoping's much publicized southern tour in 1992 as the party leadership appeared more willing to accept capitalist mechanisms such as free price and private enterprise. More and more people, including many cadres, began to set up shops, enterprises, and corporations, and become engaged in freemarket commercial activities." Government officials, sanctioned by the reform directives of the central authorities, are granted an informal approval to make their living from service-related business. They are indulged for achieving economic success.

Fundamental problem of the principal-agent framework in approaching corrupt relations is that the principal, i.e. the highest in the hierarchy of authority, is not an agent, i.e. does not represent political will and interests of his constituents. Application of the principal-agent 
framework in the context of the corruption and coercion concept is truncated by this initial stage where central authority is an agent of the population.

Inability of the central authorities to seek sustainability of the regime among its constituents urges them to rely on informal mechanisms of control. While formal mechanisms of exercising political power preserve their legality and visibility, the informal ones become of primary importance and slowly replace formal mechanisms of control with corrupt mechanisms. This replacement soon acquires systemic characteristics. One can trace the following sequence: singular-particular-system--unity. While on the first stage corruption as a form of control occurs on the case-by-case basis, on the second stage it is a recognized phenomenon, on the third stage it is broadly used by different branches of authority and acquires systemic characteristics, and on the last, fourth stage it is a norm, not only well-established but unavoidable. Along the sequence line the informal first emerges, then develops, becomes predominant, and finally overcomes the formal, while the formal being absolute on the first stage declines down to the fiction at the last stage. The informal becomes real and the formal becomes nominal. Agent becomes accountable to his principal not only on the formal level, but also and mostly on the informal level.

Presence of formal channels of power is explained by the two factors: 1) certain social constraints imposed on the members of the central authorities by the voters, and 2) by the necessity of legal coercive power to enforce mechanism of corruption and coercion. At the same time informal channels of power become predominant ones.

The principal who cannot rely on population as a primary base of his power and formal authority requires from the agent both loyalty and compliance and expects from him to be helpful in receiving public support. In exchange, the agent receives both the informal 
authorization for the corrupt activities and cover-up from the principal. In this case principal is more concerned with personal fidelity of the agent and his willingness to share the benefits from corruption rather than with his performance of the formal duties.

\section{Economic rationale for the vertical structure of control}

Economic models of corruption are relatively well-developed. Milovanovic (2001) investigates rent-seeking behavior and corrupt processes of privatization and focuses on countries in transition. Red tape imposed by bureaucrats and utilized as a mechanism of extortion and conditions of corruption in equilibrium are presented by Guriev (2003). Guriev (2003) explains ex-ante and ex-post corruption, first studied by Shleifer and Vishny (1993) as "corruption without theft" and "corruption with theft," respectively. Waite and Allen (2003, p. 292) make a distinction between top-down and bottom-up vertical structures of corruption. They

point out that "in corrupt systems the gains are also realized from siphoning off from the "public through" (top down)."

Bottom-up flow of money means sharing of the benefit from corruption with higher structures or officials in the hierarchy. Developing market economy is not presupposes reduce in corruption. Practice shows that in many instances more market means more corruption based upon the fact that development of the market and the economy enlarges primary economic base for corruption. Gong (1997, p. 277) describes the dynamics of corruption in China and points out that "in contrast to the conventional wisdom that marketization is essential for reducing corruption, the sources of corruption are many and complex." 
Huntington's (1968) well-known argument is that corruption works as a "grease-in-thewheels" and so may be good for growth since it relaxes the rigidity of bureaucracy. A prominent democratic leader and then mayor of Moscow proclaimed this theory in early 1990s. The idea was, again, that corruption in transition societies is invaluable as "grease" or machine oil for the proper functioning of the state machine, or as an antidote against inefficient organization of society and bad state policy (Polterovich, 1998; Kagarlitsky, 2002; Shlapentokh, 2003). Tanzi (1998) criticizes this approach pointing out that "when rules can be used to extract bribes, more rules will be created." He (2000) describes cost and benefits of corruption in transition economies arguing that in the rigid bureaucratic structures corruption is bad and good at the same time. Organizational hierarchy models may be found in Tirole (1986) and Laffont and Tirole (1991).

Goorha (2000) presents two approaches to the basis of corruption, saying that under the Pigovian approach corruption is a byproduct of government intervention and under the interest group approach it is based on politicians acting as deal-makers. Solomon and Foglesong (2001, p. 76) suggest that "individual acts of corruption in postcommunist countries are part and parcel of a powerful and genuine form of social organization, that is, clientelism." They refer to Sajo's (1998) work on corruption saying that "corrupt activity by officials and businessmen in Eastern Europe does not reflect a moral deficit but rather a structure of opportunity, in which there is no viable alternative to clientelist relations. In fact, Sajo warns us, no confrontation with corruption, including conflict-of-interest rules, can serve more than a public-relations function, as long as clientelist dependences predominate, private property is not well demarcated and protected, and there are no guaranteed salaries to safeguard personal autonomy." (Solomon and Foglesong, 2001, p. 76) 
Positive role of the state in developing and sustaining corruption is often underestimated. Prominent Russian economic reformer Chubais, famous for his liberal views and privatization, said that "Corruption depends very little on the authorities. It depends on the people." (Chubais, 2002) Shlapentokh (2003, p. 156) criticizes Putin for his declarations about strengthening the state and at the same time avoiding taking serious action against corruption and commenting on the issue of corruption in the media. For us it is normal, because according to the concept of corruption and coercion strengthening the state through vertical administrative hierarchy is exactly what is necessary to advance the policy of coercion through corruption. This policy, in its turn, leads to further strengthening of the state machine. Accordingly, Russian leader always says about the importance of administrative resource and managed democracy.

The processes of sharing and profiteering create a base for and strengthen the vertical structure of the corruption and coercion mechanism. Degree of sharing of the benefits from corruption is an indicator of strength of vertical hierarchy. Formal frame is necessary to enforce sharing and the state is utilized as a formal structure for that matter. Zhdanov (2002, p. 7) suggests necessity of existence of such formal system by saying that "The perpetrators of corruption cannot exist without the official subsystem. This subsystem is a necessary prerequisite for them to establish corrupt relations; in order to abuse authority, one must first posses it. One must have been appointed to an appropriate position within the agencies of central governmental authority (or local self-government), and must have both actual powers and the opportunity to use them officially. Besides that, the official subsystem serves as a cover for the unofficial one. In the first place, the perpetrators of corruption use the powers granted them by the law to achieve their unlawful goals. In the second place, they use official status to evade the responsibility provided for by law." 
The leaders always expect to obtain a share of the illegal income, including income from corrupted activities. Darden (2002) creates an impression that the leaders are only concerned about obedience and secrecy of bribery and embezzlement, when their primary concern is rather about the sharing. Strength of the vertical hierarchy is defined not only by blackmail-loyalty relation, but by the share subordinates pay to the top, or so-called "roof."6 Good description of the cluster of corruption rights (by analogy with the property rights) would be a significant contribution to the field. There are numerous records and research statements that public offices are on sale and profitable or bread-winning places are bought-out (Gong, 1997, 2003; Gorha, 2000; He, 2000). Rose-Ackerman points out that "Initially, payoffs to superiors may be a means of buying their silence, but if payments are institutionalized, they become a condition of employment, organized by superiors for their own gains.” (Rose-Ackerman, 1999, p. 83) Gong (2003, p. 100) states that in China "today, buying and selling office has become a rather common phenomenon." We argue that distribution of these places occurs not only on a market basis, but a basis of present and expected loyalty to the regime. In China, the policy of "making money by public institutions themselves" allowed public institutions to make money to supplement their insufficient budgetary income and improve their staff members' welfare (He, 2000, p. 252).

The central authorities in China reduce or even terminate financial allocations to their subordinates. Moreover, as it happens in Cuba, public institutions and businesses are expected to donate into the different local initiatives, assuming that they are a priory corrupt and are hiding some of their revenues from taxation.

Issue of the "second" salary in exchange of loyalty is of primary importance in understanding economic incentives for corrupt behavior and its use for the vertical administrative

\footnotetext{
${ }^{6}$ Krysha.
} 
control. Here is another view on the same problem. First, the issue may be that there is no formal, or "first", legal salary. Or at least it is not a salary in its real meaning, with its economic and social functions. Interesting analog from the same historical personage Ivan Grozny would be his prescription to the unpaid government servicemen and officials throughout the Russian Empire to "feed from the service." This does not lead to creating a loyalty by authorizing the additional, "second" salary, that is bribes, but rather to "legalize" or authorize the process that is already in place nationwide. Second, there is no need for the state to take a burden of financing its employees through the fiscal system and redistribution. These corrupted, indeed market-based mechanisms work directly, maintaining the flow of resources or income from the public to the state officers.

\section{Model of compliance and control}

Those state officers or public officials whose present "legal" salary plus bribes minus risks of taking bribes are equal to the fair market salary that would be paid otherwise are indifferent to the current regime and hence irrelevant to the regime's agenda. This may be expressed as the following equation:

$$
p s+b-r=f m s
$$

where $p s$ is present salary, $b$ is total of bribes and other benefits from corrupted activities, $r$ is cumulative for risks connected with corrupted activities, and fms is fair market salary. 
Those public officials, whose $p s+b-r<f m s$ are potentially in opposition to the regime. Those public officials, whose $p s+b-r>f m s$ are in support of the system, and as so, of the regime, which maintains continuity of the system.

Regimes in Russia, Ukraine, and other countries of the FSU are often personified. If other candidates for the leadership positions promise better benefits, both legal and/or illegal, the "supporters" will be willing to overthrow the current regime, not to say about those "indifferent" and "in opposition".

In these circumstances the primary task of the current personified regime in order to sustain its existence is creating and maintaining of the system that maximizes $p s+b-r$ and minimizes fms. Since any positive integer for $r$ decreases left side of the equation, the task is to maximize $p s+b$ and minimize $f m s$ and $r$. The following equation would be a good first condition for sustainability of the regime, based on corruption:

$$
p s+b>f m s+r
$$

The Grozny's "feed from the service" authorization and approval of fair corruption is exactly diminishing $r$ to zero in order to balance the equation, where $p s$ of unpaid servicemen is equal zero.

More interesting is that the equation allows seeing the issue of loyalty under the wider angle. Local authorities and heads of the state enterprises and joint-stock companies are, indeed, not only economically influential, but have significant influence on the voters. The question one might ask is what are the criteria for the selection for the key positions, where loyalty is crucial for the regime? In distinction of early times of transition, when loyalty had to be "earned" from 
the existing directors and chairmen in exchange for other benefits, in present times directors and especially local authorities are appointed by the leaders. One may agree that a common feature of the new local leaders is that they are not very bright and are lacking leadership skills, education, honesty, etc. The answer on the question is that their fair market salary $(f m s)$ is minimal. Therefore, by reducing the risks ( $r$ ) to zero, the regime can maintain stable loyalty of the local leaders with the relatively low present salary $(p s)$ and benefits from corruption $(b)$. It should be noted, that the $r=0$ only for those who are loyal to the regime. Potential presence of the risk of punishment gives to the regime not only loyalty, but the right to share in the benefits from corruption. In this sense graft is not only a basis for the blackmail, but also the result of a certain kind of a social contract.

Goorha (2000, p. 32) suggests that better paid public officials are less corrupt: "That the PPP GNP per capita has a negative partial effect on corruption in both regressions can perhaps be explained on a more intuitive level. If we allow the value of this variable to be a proxy for the level of pay of corrupt agents and in particular government sector employees, we would expect that a rise in the average level of pay would decrease corruption. A substantive affirmation of this result awaits detailed government sector wage level data in each transition economy considered." This statement is based on the assumption that there is a correlation between per capita GNP and public official's salary, which may not be true. Also, this statement does not reflect what we have done in our model, i.e. public officials are appointed on the basis of their low opportunity cost expressed in terms of their fair market salary on the open labor market.

According to the data analysis, presented by Shleifer and Treisman (2003, p. 27-28), the level of administrative corruption is very high in poor countries of the FSU, such as Uzbekistan, Armenia, and Azerbaijan, lower in Russian Federation, Bulgaria, and Lithuania, and even lower 
in relatively wealthy Hungary and Slovenia. Individuals' perceptions about corruption put Russia lower than Argentina, Brazil, Romania, or Lithuania. This supports our suggestion that underpaid public servicemen and officials are most likely to be corrupt and that this is a broadly accepted practice of financing public services by the government.

\section{Horizontal structure of control}

So far we have considered a structure of administrative control, based on corruption, which we have identified as vertical. Horizontal structure of this type of administrative control may be of no less importance than the vertical one. Horizontal structure mostly addresses issues of the relations of colleagues of a certain institution, organization, department, division, or subdivision, i.e. organizational unit, who operate on the same level and are located on the same ladder of subordination.

Horizontal structure of administrative control and corrupt relations can be considered as existing in the following two environments: competitive and noncompetitive. Competitive environment is an environment where an employee can benefit from dismissal of or reprimand to his colleague or colleagues. Open competition is not a necessary characteristic of the competitive environment.

In the competitive environment the employee will report, either formally or informally, on his colleague's misconduct to the administration. Before reporting, the employee will, of course, weight possible benefits and costs of the reporting. The benefit may be caused by the dismissal of or reprimand to the colleague while the cost may be the report of the colleague on the employee's misconduct in respond. This situation may well be described using the frames of 
the game theory. If the expected benefit is greater than the possible cost of the contrary report in respond, then the employee will report.

Administration benefits from this type of competitive environment and encourages it. Employee's reporting behavior in the competitive environment gives the administration an opportunity to exercise its blackmail based administrative control without even collecting compromat ${ }^{7}$ through the own internal investigations. The function of checking the information, however, exists. Administration normally receives information on wrongdoing from the several sources and if it describes a particular case or behavior in a same way, then this information is considered as trustworthy.

Internal investigations are normally launched by the administration not at a time when the signal of misconduct is received, but when it has already been decided who will be dismissed, and who will replace the dismissed. Therefore, the internal investigation becomes a formality, necessary to put a procedure in a proper form. Internal investigation may also be used as a last warning for the non-complying employee that he should comply rather than that he should stop his wrongdoing. Often an employee is dismissed even without launching an internal investigation. Instead he is proposed a choice of either leaving the position or being put under investigation. This type of adverse procedure is in fact one of many indications of adverse process of social transformation overall, where created institutions precede emergence of their functions and where legal procedures are used to enforce informal or illegal processes. In any case, an internal investigation is used when an employee does not comply with the administration.

${ }^{7}$ Compromat, or compromising materials - materials or information, evidence of misconduct or wrongdoing, used for accusations in illegal or immoral activities. 
Noncompetitive environment is an environment where an employee cannot benefit from the dismissal of or reprimand to one or several of his colleagues. This noncompetitive environment does not exclude a possible presence of an open competition. For instance, if employees in the department compete openly in volume of sales or number of publications, this competition is a part of their job and does not violate the condition of noncompetitive environment.

Certainly, there are reporting of misconduct occur in noncompetitive environments, but these reporting are not based on the rational behavior, as it happens in the competitive environment. Reporting in noncompetitive environment is based on personal relations, including sympathies and antipathies, and patterns of behavior. This type of motivation may be considered as irrational.

Noncompetitive environment may be separated on cooperative and neutral. In the neutral noncompetitive environment an employee is indifferent to whether his colleague is dismissed or is getting reprimand or he is not. Good example to illustrate this type of environment would be a tickets sale on a large train station. Employees of the book-offices often hold tickets on those trains, where number of potential passengers is higher than the number of places, and then realize these tickets through the agents for the higher price. Due to a large number of the ticket sellers, they are indifferent to whether their colleague gets dismissed for this type of wrongdoing. In the cooperative noncompetitive environment an employee will be impacted negatively if his colleague is dismissed or reprimanded. This negative impact may be formal, or informal, direct or indirect. An example may be any organized net of corruption. In the Former Soviet Bloc it is a well-known situation, called "krugovaya poruka," where "one will not find the ends" or 
"one will not find a guilty." ${ }^{8}$ It can be presented as a "circle of mutual guarantees" or a "circle of silence," based on the principle of reciprocity. This type of cooperative noncompetitive behavior may also be characterized as a cover up. Cover up may be of two types: internal and external. External cover up takes place when the employees defend each other before the clients or representatives of the general public. Internal cover up is a situation when colleagues try to defend each other before the administration.

Below we will give a brief classification of negative impacts of the colleague's dismissal on the employee, which can take place in a cooperative noncompetitive environment:

- Formal negative impact - dismissed colleague may choose to report on the employee, his peer, and this employee will be dismissed as well

- Informal negative impact - the employee will fall under the suspicion in wrongdoing or an extra surveillance, based upon the fact, that his colleague was accused in wrongdoing

- The employee may be dismissed as a partner or a suspected partner in corrupt activities

- Indirect negative impact - the employee looses a partner, and who knows, how the new colleague, replacing the dismissed one, will behave

Counter-motivation to report based on the fear of an indirect negative impact is especially widespread in organizations or environments where the certain level of cooperation is necessary for corrupt activities (so-called corrupt chain), or maximizing an illegal profit and benefits from corruption (pool).

\footnotetext{
${ }^{8}$ Vinovatogo ne naidesh.
} 
Horizontal structure may also be presented in a different way. For instance, it can be separated on neutral and non-neutral. In this case both competitive environment and cooperative noncompetitive environment will be included in the non-neutral environment. Non-neutral environment will be defined as an environment where an employee will be impacted either positively (benefit) or negatively (bear a cost of) in case of dismissal or reprimand of his colleague. This way of analyzing the horizontal structure will ultimately be using the same tools and descriptions given above.

In the neutral noncompetitive environment administration will encourage reporting of misconduct by creating an atmosphere of mutual distrust, suspicion, and personal antipathy among the colleagues.

In the cooperative noncompetitive environment administration is often itself a part of the corrupt network, including the role of an organizer and a leader. Vertical redistribution of the revenue from bribes is an essential feature of this type of cooperation. Nevertheless, control is important for the administration. First of all, if administration is involved in wrongdoing, it $a$ priory has compromising information on its subordinates. Administration also controls for an aside activities or extra profits drawn by the subordinates without a prior acknowledgement and sharing with administration. This can be named as a control over generation of illegal revenue squared. This situation is depicted on the scheme as a vertical link.

In case when administration is not involved, it has to break a cover up in order to get a compromat on its subordinates. Infiltration of a stool-pigeon is one of the tools to get the necessary information and then blackmail the subordinates and propose them a cover in exchange of loyalty. Another tool is to enforce one of the employees, accused in wrongdoing, to inform on his colleagues under the threat of dismissal or criminal prosecution. Extra benefits or 
favor may work as well. It is depicted on the scheme as a cover up. The horizontal structure of control is presented in Figure 12.

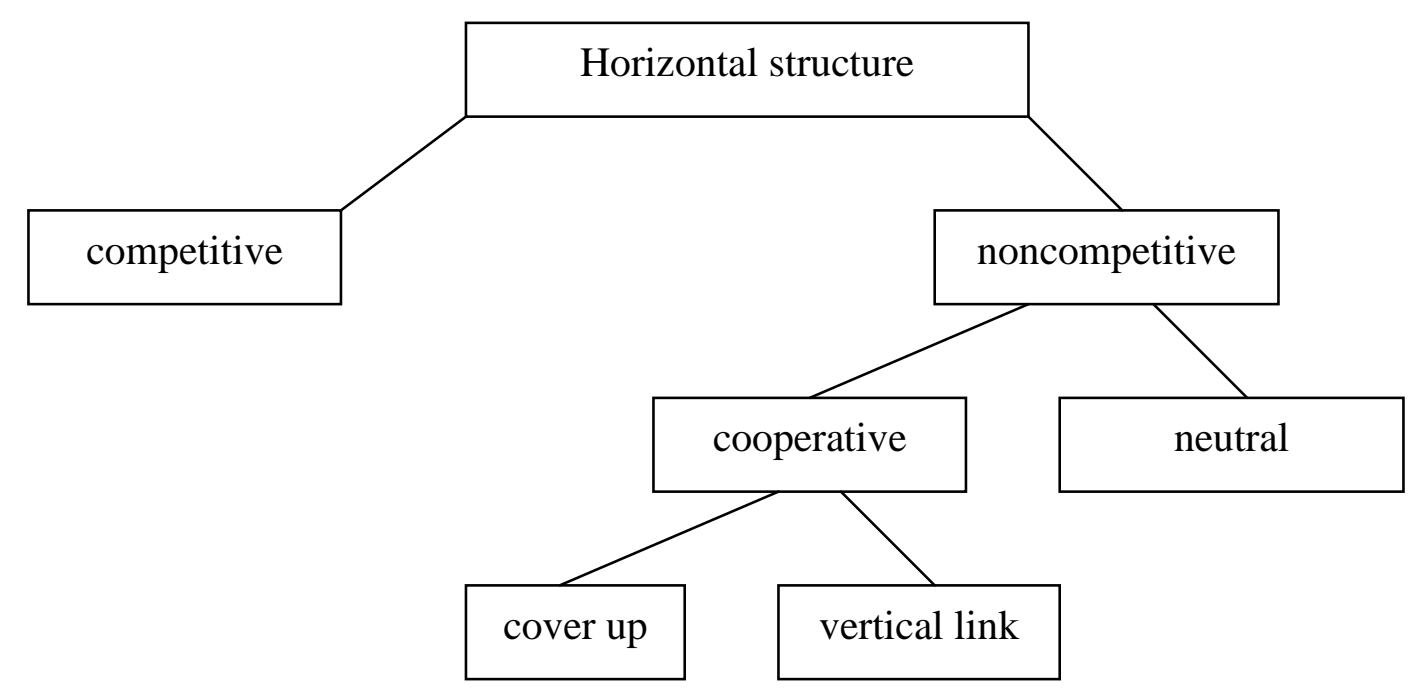

Figure 12. Horizontal structure in administrative control with corrupt behavior

\section{Genesis of state-university relations}

In order to follow how mechanism of corruption and coercion may be applied to higher education and higher education institutions of the FSU in particular, we will first consider relations of the university and the state in historical perspective. It should be said that at the time when first institutions of higher education emerged in Medieval Europe, there were no nationstates and there were no social institutions in our contemporary understanding as well. Medieval Universities did not play a significant role in the social life and the state did not pay much attention to politicization of the learning institutions.

Hyde (1972, p. 19) warns against a false dichotomy between the worlds of learning and of politics, based on an underestimation of the social links between them saying that "This 
illusion is easier to sustain in considering periods when both states and institutions of learning had well-defined constitutions. By looking first at a time when both worlds were still in a state of flux, the reader may be reminded that neither academics nor politicians work in isolation, but both are rooted in society - in this case, the cramped, violent, and competitive society of medieval Bologna."

University autonomy in the Middle Ages was something natural, a part of a guild structure of the society, and not a result of the institution's struggle for its self-governance and financial independency. However, university development and its growing social influence urged leaders of the feudal states to consider university as a player on political arena. The states started to develop relationships with the universities and universities had to establish certain nets of external relations. Universities had acquired not only charters, granted by the states, but also Papal privileges. Thelin (1982, p. 32) offers very precise description of how university external relations were built at that time:

The major structural gains for a university lies in its history of external relations acquisition of privileges, exemptions, and a charter. The pattern involved three stages: first, a university gained the ecclesiastical status which made it immune from local secular urban jurisdiction; second, it received royal exemptions which meant that the king protected the university from both city authorities and the bishop; finally, a university was granted papal privileges, which meant that the institution was accountable to Rome, exempt even from control by a nation's king.

University privileges were often granted after a dispute between student s and local authorities. Squabbles between "town and gown" gave a king a convenient excuse to 
intercede and to extend his own authority over a city. Philip Augustus, for example, made the following rule in favor of students at Paris in 1200:

Neither our provost nor our judges shall lay hands on a student for any offence whatever; nor shall they place him in our prison, unless such a crime has been committed by a student that he ought to be arrested. And in that case, our judge shall arrest him on the spot, without striking him at all, unless he resists, and shall hand him over to the ecclesiastical judge, who ought to guard him in order to satisfy us and the one suffering the injury.

Thus, students were given clerical status, accountable to ecclesiastic authority; they were protected from civil authorities. The privilege was set "forever by fixed law" that the university provost would affirm by oath to the scholars to abide by the king's regulations. State leaders and the church used universities for their political purposes and control over the curriculum. By granting special statute to a university a state leader received a tool of influencing a town where this university was located. It granted certain immunities and privileges to university students and professors and consequently expected loyalty in exchange. In its turn, Catholic Church was influencing local leaders by using universities as one of the tools of internal pressure. From this it may be concluded that universities were historically important ideological institutions and gained more weight in being politicized. The church, the city governors, and the local leaders were interested in controlling universities and guaranteeing their loyalty in order to sustain themselves.

Vagueness of the social role and functions of the early European universities and their loose relations with the state are certainly not a characteristic of the Russian university system. University system in Russian Empire has been developed under the different scenario. From the 
very beginning the state was the initiator, promoter, financier, controller, and benefactor of the university system. Moreover, the state was the only institution to perform these functions. Therefore, the university system in Russia is traditionally centralized. The Ministry Education in Russia was created at the time when there were only two universities in the country: St. Petersburg University and Moscow University.

Flynn (1988, p. 3) describes creation of the university system in the Russian Empire under the auspices of the newly established Ministry of Education: "It soon was agreed, in 1802, to found a Ministry of Education whose governing body, called the Main School Administration, would direct all education throughout the empire through six universities, which were founded between 1802 and 1804. Moscow State University, founded in 1755, was redesigned in 1804.” The ministry subcommittee worked on drafting legislation and the statutes for universities.

Not everything went successfully at the start. Successful restructuring of Moscow University was counterbalanced with the extreme difficulties in Kazan: "At the other end of the scale, as well as opposite side of the empire, the university at Kazan clearly was a failure. Many professors had been recruited from German universities, but few stayed long in Kazan. At no time did the faculty number more than half that required by the statutes, while the student body never exceeded fifty. University autonomy, i.e. faculty self government, was not attempted, for the curator simply appointed a 'director' while not permitting election of a rector or the convening of a council until late in the decade." (Flynn, 1988, p. 8) The result of this top-down approach in governing the established rather than emerging university was that professors did not have too much of a freedom. Not much professors could do about it but to leave.

In distinction of Kazan, Kharkov University has developed successfully thanks to the centralized power and effort of the state-appointed curator: "Kharkov was not so badly off as 
Kazan, in great part because its curator S. O. Potocki, energetically pursued his task in recruiting faculty, insisted on the election of rector and council according to the statutes, and even found a way to borrow students from the church's local college, when too few students enrolled to make feasible the opening of the university in 1805." (Flynn, 1988, p. 10) Centralized effort of the state brought its fruits: "By the late 1830s, none of the universities had fewer than four hundred students while Moscow enrolled nearly nine hundred.” (Flynn, 1988, p. 18) This state involvement in the process of the university building may be explained by two facts: first, state was the only force capable of creating the university system; and second, state was interested to create a system where state control would be an immanent part of the existence of the universities.

Flynn (1988, p. 19) describes position of the state authorities regarding control over universities: "Tsar Nicolas I meant clearly to answer the university question by blocking the university's ability to promote change. He wanted the universities to serve the common good by supporting the autocratic Russia he had inherited from Peter the Great and his successors. This proved difficult, perhaps impossible, even in the short run. It was difficult even to find new rectors, unless the government was willing to pass over the men obviously best qualified for the posts. Thus, the rectors appointed were the same men previously elected.” The Soviet system of higher education inherited some of the essential features of its predecessor, the university system of the Russian Empire. Weak university self-governance was counterbalanced by the strong state control. In Coleman's (1965, p. 226) words, “The Soviet Union has built up a single monolithic educational system under omnipresent party control with heavy inputs of political indoctrination at all levels." 


\section{Vertical structure of control}

Vertical structure of control in higher education incorporates principal-agent frame. Besides the general interest of administrative control, described in the previous parts of the chapter, there could be a special interest of such control as well, depend upon a particular industry or a major governmental institution, to which it may be applied. Obviously, the general interest of administrative control through corruption and coercion is present and fully applied to the higher education. We will describe the special interest of maintaining administrative control over the higher education. This special interest is closely linked to and often indivisible from the general interest, but it is based on the distinctive features of higher education, including its special role in the society and its organizational and cultural characteristics and norms.

It is fact that universities became by far most important institutions for political socialization. As Almond (1960, p. 324) puts it, "Political socialization is the process of induction into the political culture." Importance of the educational system in codifying people in the process of political socialization is stated by Coleman (1965, p. 18): "The concept of political socialization is now an accepted part of the vocabulary of political science. It refers to that process by which individuals acquire attitudes and feelings toward the political system and toward their role in it, including cognition (what one knows or believes about the system, its existence as well as its modus operandi), feeling (how one feels toward the system, including loyalty and a sense of civic obligation), and one's sense of political competence (what one's role is or can be in the system). The educational system is one of the agencies involved in this process, which begins at birth and, also its imprint is most pronounced during the impressionable formative years, continues well into adulthood." 
Universities have substantial political power due to the three major facts. First, university professorate constitutes most intelligent part of a society and its elite. Professors often participate in political life, occupy public offices, and work as consultants and advisors to politicians, public officials, and administrators.

Second, students in many countries are one of the major political forces that easy to politicize and mobilize for social actions. Califano (1970, p. 23) describes student unrests and states that the Japanese radical students appear to be, by far, the most successful in the world in disrupting the social order: "Tokyo University was paralyzed by a student strike throughout 1968. It took eight thousand policemen two days to evict radical students from the main hall of the University in January 1969 - a two-day siege, similar to the later one at Kyoto, which ended an occupation that had lasted for over six months.” As Jarausch (1974, p. 567) states, student movements are often successful in shaping a critical generational identity than in achieving practical political, social, or institutional aims. Jarausch points that the failure of the student movement to reach its reforming goals largely due to its elitism may lead to incompleteness of modernization.

Third, universities are large enterprises that involve not only employees, i.e. faculty, administration, and staff, but also their immediate consumers, i.e. students. For instance, Moscow State University hosts under its roof around fifty thousand students, professors, administrators, and staff. This makes university an object of primary importance for the state. Control over the universities means control over their curriculum, ideology, and behavior, and is a highest stake for the regimes that want to sustain themselves. While state funding for university is constantly decreasing, there are other mechanisms of control taking place. Replacement of 
direct state funding as one of the primary mechanisms of control over the universities by the corruption and coercion mechanism is an obvious trend in the FSU.

In the environment where everyone demonstrates rent-seeking behavior, it seems irrational to stay aside of the "mainstream" of economic development, including corruption. Instructors in higher education are intelligent people and understand that their position give them opportunities for receiving benefits beside their miserable salaries. The government forces the instructors to think quickly by not paying them in time or below the poverty level and encourages them to take bribes by turning a blind eye on corrupt practices in universities. Indulgence, as a necessary detail in the mechanism of corruption and coercion, is presented here in the form of informal approval, most often expressed as opinions and views of public officials and administrators and tolerance of the general public.

Opinions on corruption in higher education vary. For instance, the Rector of Moscow State University, Victor Sadovnichiy, ${ }^{9}$ offered the following comment on the news about the arrest of two corrupt professors in one of the Russia's regions: "Until the country will start to think whom, what, and how it teaches, to organize demonstrative prosecutions for bribers in universities is immoral and not clever. It is a blasphemy to require high moral principality from a professor who lives on $\$ 50 . " 10$ Sadovnichy (2001) sees causes of corruption among college teachers not in terms of their moral standards, but in the manner in which they are treated by the government. He also suggests that “...education in universities should be free. Of course, commercial education also should have a right to exist, but it should exist separately from public education." Another problem is demographic. Because of birth rate decrease, there will not be

\footnotetext{
${ }^{9}$ Position next to the Minister of Science and Education.

${ }^{10} \$ 50$ is referred to as monthly salary.
} 
students in the country soon: "I have data that, for instance, six thousand entered University of Mordova this year, and 7200 were born in the republic.” (Sadovnichiy, 2001) ${ }^{11}$

Sharing and profiteering in state-university relations does not occur on a regular basis. Sharing is not a widespread practice in the relations between the state and universities. Visual secrecy of a university is maintained by the government. Even share in bribes is sacrificed in lieu of this image. Of course share in bribes would be insignificant, and benefits are still drawn by the public officials in form of their children placement to the universities.

Corruption in higher education institutions, even if flourishing for the last fifteen years or so and existing previously, is still not well-institutionalized. Rampant corruption is often occurs on the non-systemic basis. Distribution of corrupt functions develops along both vertical and horizontal axes and so does distribution of corrupt benefits, derived from corrupt functions. This vaguely institutionalized scheme does not lead to the vertical redistribution of wealth either within the institutions or between the institutions and supervising state authorities. Based on this statement one can draw a distinction between institutionalized corruption and institutionalized redistribution of wealth, accumulated from bribes. In higher education institutions illegal benefits, especially those received in cash, are not shared vertically. This feature makes higher education industry different from most of the other businesses. Of course, this is rather a general characteristic, than a rule. Vertical sharing of bribes occurs in some indirect ways on case-bycase basis between private fro profit colleges and universities and local authorities and controlling state and educational agencies.

${ }^{11}$ Commercial education is the definition generally used to identify private for-profit higher education institutions.

Mordova is one of the republics of the Russian Federation.

University of Mordova is the major higher education institution in the Republic. 
Russian reform of higher education that includes admission based on the results of the national test General State Examination (EGE) and State Personified Financial Obligations (GIFO), often referred as educational vouchers, shows that the state can interfere in the sphere of interests of university faculty and administration. Besides the fact that the reform is an attempt to adjust system of higher education to the new demands of the economy and make mechanisms of financing and admissions more adequate to the present realities in the changing society, it may also be interpreted as a step of increasing level of risk and decreasing the basis of corruption in higher education. This offence on the university placement as a domain of faculty and administration may well be a part of the state blackmailing campaign. Separation of powers between universities and the state is not an option for the regime and so it continues developing mechanisms of control. Most likely, the reform will never be completed or fully realized and faculty and administrators will preserve certain level of discretion and illegal benefits in exchange for the loyalty and compliance with the authorities.

Critics of the reform predict an increase in educational bureaucracy and transaction costs, necessary to regulate EGE and GIFO financing schemes. The EGE is criticized not only from the positions of its rational, preparedness, and objectivity. More and more often the test is being condemned for its high level of corruption. The Dean of the School of Economics at Moscow State University, Victor Kolesov, contemplates that "A mythical billion in bribes, offensively ascribed to the heads of the top hundred higher education institutions, will be materialized and distributed among thousands. Corruption in this way will be 'democratized' for sure." (Kolesov, 2002)

The reform presents real threat of redistribution of bribes and illegal benefits in highly corrupted sphere of entering higher education institutions from the faculty to secondary 
education and administrators. In the present system faculty of higher education institutions make selection and decisions on the enrollment. If, however, entry examinations in colleges will be abolished and the EGE score will become major factor defining enrollment decision, secondary education administration and school administration are more likely to obtain most significant control over the enrollment by obtaining control over the elaboration and administering of the general state examinations. Presence of truly independent agencies in this sphere is very doubtful.

It is obvious, that the college faculty will strongly oppose this threat to one of the major sources of illegal income. Monopoly on regulation and selection in entrance to higher education budget financed places will be defended by any means. Preserving certain number of fully and directly financed from the budget places may become a compromise between the authorities and the faculty. While bribes in cash and in kind may decrease in their volume and number of cases, faculty and administration will continue to secure state-funded places for their children. Public universities will continue to be operated as family enterprises. This invisible corruption will satisfy both the authorities and university faculty and administrators.

\section{Horizontal structure of control in universities}

Universities are not just organizations but social institutions. They are living organisms that reproduce themselves. Corruption in these institutions is as a disease in the organism and develops not only along the vertical, but horizontal axes as well. The horizontal structure of control developed in the first part of the chapter is now applied to investigate the specifics of higher education institutions. The implications of the horizontal structure for the higher education institutions are presented in Figure 13. 


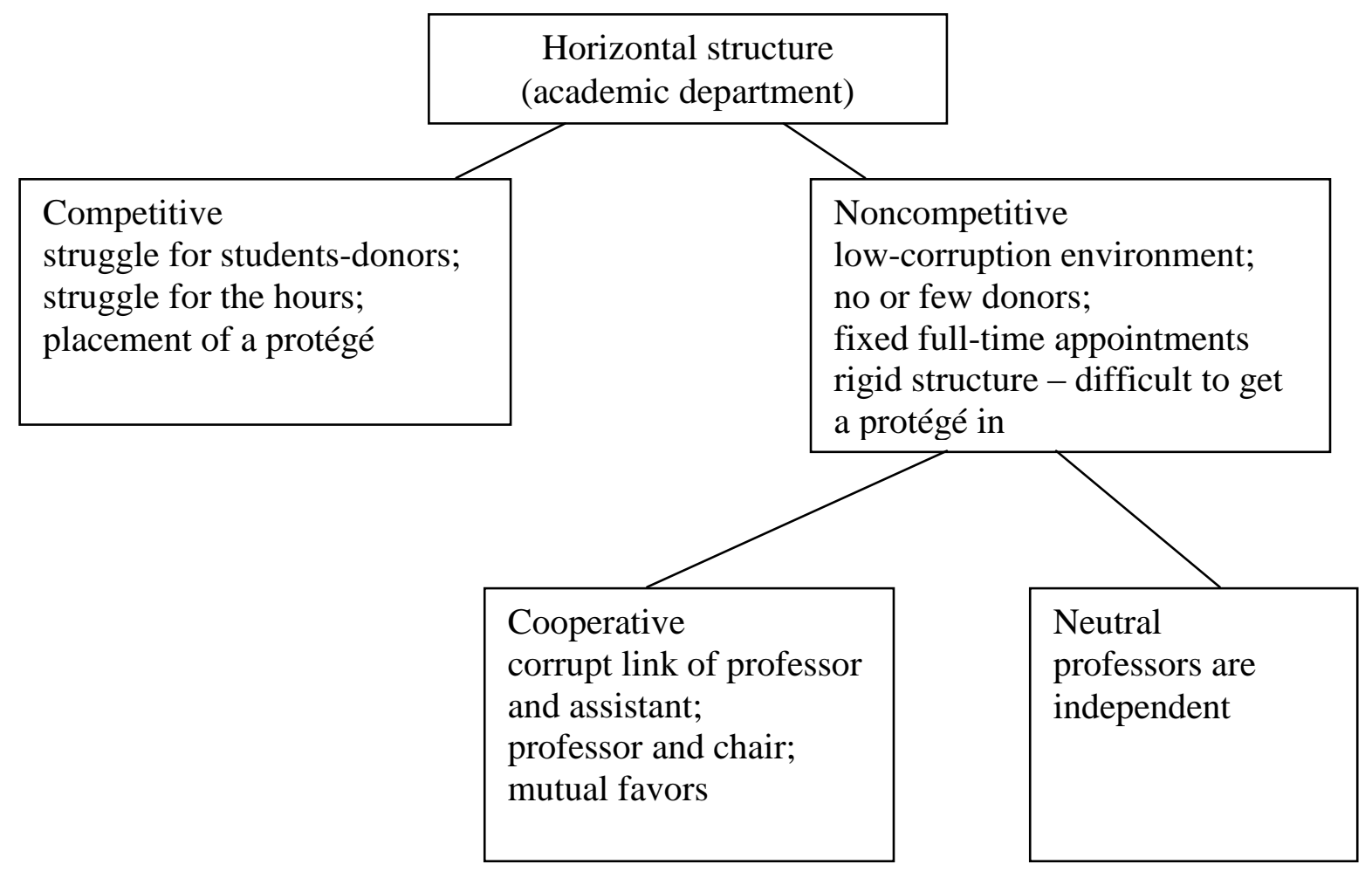

Figure 13. Horizontal structure of administrative control in the university with corrupt behavior

For this scheme, the department is a basis for analysis. In competitive environments faculty members struggle for students-donors, i.e. students who pay or may potentially pay bribes. They also struggle for a workload since more teaching hours bring more money in the form of a salary. Teaching hours differ and so a struggle also occurs over the teaching hours that require less of a real in-classroom course-load. The placement of protégés is another broadly accepted form of wrongdoing. Some state universities are by now transformed into family enterprises, where many students are relatives of faculty members and administrators and were 
accepted into state-funded places without a due competition process. Competitive environments are corrupt.

Non-competitive environments are much less corrupt. There are either no or few studentdonors or potential donors. Faculty members hold full-time appointments without the right to work overtime and the workload is fixed. Departments with non-competitive corrupt environments are also characterized by a rigid structure where corrupt activities are often difficult to promote.

Noncompetitive environments are further classified as cooperative and non-cooperative or neutral. In cooperative environments there is often a corrupt link present between the professor and his assistant. Professor may ask his assistant to leave some under-performing students while they take examinations and then try to get some benefits from these students. The same link may be present in relations between the professor and the chair of the department. Mutual favors are a major form of informal activities in these environments. Mutual favors include accepting students and assigning grades as a favorable act to the asking faculty member, administrator, or a friend. In these cases cash does not change hands.

Neutral environments are characterized by a high degree of professor independence. Professors do not influence each other and the administration does not have strong authority over professors.

\section{State-university relations}

The state is involved in higher education to a larger or lesser degree in any country. Nevertheless, many countries manage to avoid development of the vertical mechanisms of 
control presented in the corruption and coercion concept. Formal mechanism of influence, coordination, and control are either predominant or the only mechanism of channeling power, and informal mechanisms are either secondary or absent. Undoubtedly, central authorities exercise their authority over university through the variety of ways. Plurality of forms of funding, both direct and indirect, based on competitive and non-competitive bases, are used as a tool to exercise this authority. The forms differ depend upon their application to public and private universities.

Burns et al. (2000, p. 46) present major forms of the state influence through the funding mechanisms as follows:

About half the students are likely to be receiving some form of a national or state financial assistance to help pay their tuition and fees. The institution itself is chartered by the state. Most of the funds that pay for the teachers, staff, and buildings at public institutions come from state appropriations, state bonds, private gifts encouraged by national tax laws, or a combination of national, state, and private sources. Faculty research, especially in the sciences, is likely to be supported by some combination of national, state, and private (yet tax-deductible) dollars.

Another form of influence besides funding is formalized in the certain codes, rules, regulations, and restrictions, imposed on universities by the central authorities. Some of these rules are obligatory for all institutions while others are complementary and supported by financial incentives. The universities that comply with the rules enjoy the access to some state and federal funds through participation in grants, programs, and projects. Burns (2000, p. 46) describe some of the regulations imposed by the state authorities on universities: "The conditions under which students are admitted, how their grades are posted, and reported, and how faculty 
and staff are appointed and evaluated are subject to national and state regulations. The use of experimental animals is subject to governmental supervision, and national and state inspectors check to ensure that laboratories properly dispose of used chemicals."

In the FSU, rules and regulations, including accreditation, curriculum, degree requirements, and reglamentation of the academic process, are used by the state as tools of administrative control. Often the tool becomes more important than the regulation itself. This control becomes even more important when educational space is occupied not only by the state universities, but independent private higher education institutions as well. Financial independency of private institutions is disturbing and so authorities are trying to develop more tools and mechanisms of control. Introducing vouchers for higher education and entitlement of private colleges to participate in competition for these vouchers is one of these mechanisms of indirect control. Once independent private institutions are invited to compete for funds, they become interested in being qualified for participation. This qualification is of course based on the discretion of the central authorities.

The major task is to control not only public universities that always were and are under the authority of the related ministries, but also private colleges. In the FSU, universities are rather an object of public policy while in the US universities are participants in politics on the both state and federal levels. This trend may change in time and public universities may regain their autonomy from the state, but the fact itself speaks for the tendency of the central authorities to control higher education institutions and their willingness to negotiate and trade the autonomy in exchange for funding or possibly some other benefits.

Finally, the level of cheating and toleration of cheating as an indicator of looseness of control and corruptness of the educational systems may be used to project on the corrupt and 
coerce concept. Tolerance of cheating across the nations varies significantly. In the FSU, instructors often turn blind eye on student cheating. They think that they will always be able to distinct a good student from the rest. This perception is also based on willingness to control student body and exercise the authority of assigning grades depend on personal relations and attitudes towards particular students rather than on their academic progress. Findings by Magnus et al. (2002) indicate that cheating in universities is well-tolerated in the FSU while the US it is not, and Western European countries are in the middle.

The level of cheating characterizes relations between professors and their students. In the principal-agent perspective professors in corrupt universities are principals and students appear to be their agents. Professors exercise coercive power over the students and either punish them for cheating or turn a blind eye depend on students' compliance with professors' demands. Logically, the opposite should be true. Since students are consumers of educational instruction services, they should be primary principals and professors should play the role of the agents. In corrupt universities the administration plays a role of the principal to professors and professors are principals to their students.

\section{Conclusion}

The positive role of the state in developing and sustaining corruption is often underestimated. According to the concept presented in this chapter strengthening of the state through a vertical administrative hierarchy is exactly what is necessary to advance corrupt and coerce policy. This policy, in turn, leads to further strengthening of the state machine. The processes of sharing and profiteering create a base and strengthen vertical structure of corruption 
and coercion mechanism. Degree of sharing of the benefits from corruption is an indicator of strength of vertical hierarchy. Formal frame is necessary to enforce sharing and the state is utilized as a formal structure for that matter. Horizontal structure of control is utilized on the institutional level. The general interest of administrative control through corruption and coercion is present in and fully applied to higher education. This special interest is closely linked to and often indivisible from the general interest, but it is based on the distinctive features of higher education, including its special role in society and its organizational and cultural characteristics and norms.

It is a fact that universities became by far the most important institutions for political socialization. Universities have substantial political power due to the three major facts. First, the university professorate constitutes the most intelligent part of a society and its elite. Professors often participate in political life, occupy public offices, and work as consultants and advisors to politicians, public officials, and administrators. Second, students in many countries are one of the major political forces and are easy to politicize and mobilize for social actions. Student movements are often more successful in shaping a critical generational identity than in achieving practical political, social, or institutional aims. Third, universities are large enterprises that involve not only employees, i.e. faculty, administration, and staff, but also their immediate consumers, i.e. students. For instance, Moscow State University hosts under its roof around fifty thousand students, professors, administrators, and staff. This makes university an object of primary importance for the state. Control over the universities means control over their curriculum, ideology, and behavior, and is a highest stake for the regimes that want to sustain themselves. While state funding for universities is constantly decreasing, there are other mechanisms of control taking place. The replacement of direct state funding as one of the 
primary mechanisms of control over the universities by the corruption and coercion mechanism is an obvious trend in the FSU.

In the environment where everyone demonstrates rent-seeking behavior, it seems irrational to stay outside of the "mainstream" of economic development, including corruption. The government forces the instructors to seek means of survival and encourages them to take bribes by turning a blind eye on corrupt practices in universities. Indulgence, as a necessary detail in the mechanism of corruption and coercion, is presented here in the form of informal approval, most often expressed as opinions and views of public officials and administrators and tolerance of the general public.

The adverse reaction of educators is supported by numerous cases when professors go into power, i.e. occupy different administrative or semi-administrative positions. They occupy offices of chairs of different state and local committees, members of administrations, and get military ranks for teaching part-time in military and police academies. Faculty members secure their societal positions and agents attempt to become principals. This trend is common and wellobserved in the society. Businessmen go into politics to secure their property and get an access to the state power.

The concept of corruption and coercion applied to higher education demonstrates how state interests influence unhealthy institutional environments. Nevertheless, there is a hope that possible democratic changes may lead to an adequate reaction and changes in higher education. Johns (2003) asserts in regard of Ukraine that "All of the resources are in place for Ukraine to have a higher education system comparable to the best in the world. But leadership is needed. Students' leaders must be given the responsibility to create an academic culture that requires a 
high standard of conduct from their peers. Faculty must be given authority and responsibility to restructure the curricula and the class schedule to include more elective courses..." 


\section{CHAPTER VI}

\section{MODELING EDUCATORS’ MISCONDUCT WITH CELLULAR AUTOMATA}

\section{Introduction}

Misconduct in education is a serious problem internationally. As the education sector grows, so does the scale of misconduct. The large bureaucratic apparatus, overregulation, outdated and unclear rules, and poor audit create opportunities for abuse. The blending of public sector, private firms, and personal interests of educators and education bureaucrats leads to collusion and evolvement of different forms of misconduct, especially widespread in large university systems and school districts.

Educators' misconduct is not limited to embezzlement of the state funds by educational bureaucrats or collecting bribes from students by faculty members. Misconduct in education goes far beyond that and may be found in secondary and higher education sectors, in public and private sectors, in centralized and decentralized educational systems. It manifests itself in forms of bribery, embezzlement, extortion, fraud, nepotism, cronyism, favoritism, kickbacks, transgressing rules and regulations, bypass of criteria in selection and promotion, ghost teachers, cheating, plagiarism, research misconduct, data falsification, discrimination, and abuse of public property. In most of the instances corruption in education has a systemic character and hence can be modeled. Cellular automaton offers a promising methodology to study misconduct in education. It allows making forecasts, assessments, and predictions on the scope and scale of corruption within organizations. Cellular automata, used in sciences, may be applied to 
investigate corruption in large hierarchical structures of educational organizations. This chapter offers a theoretical framework and a methodology based on cellular automata to study corruption in large educational organizations, including school districts and state university systems.

\section{The problem of misconduct in education}

Misconduct in education includes misconduct that arises from university-business relations, academic misconduct, cheating, plagiarism, and other forms of fraud, misconduct in relations of professors and students including sexual misconduct, research misconduct, private tutoring that involves conflict of interest, bribery in admissions and grading, embezzlement of public funds and funds of private universities, abuse of public property, gross waste, and mismanagement of university property. All of these forms of misconduct were given consideration in numerous scholarly publications. Education misconduct can be found throughout the world, including developed nations, transition economies, and developing countries.

Major grounds for misconduct and corruption include the size of the system, amount of funds employed, intensity of monetary transactions, and complexity of the system. New York City, the largest school system in the country, has over 1.1 million students, a budget of over $\$ 14$ billion, over 1,200 schools, and 140,000 employees. Los Angeles is the second largest, with three-quarters of a million pupils, a $\$ 7$ billion budget, 900 schools, and 80,000 employees. Chicago, the third largest, has half a million students, a $\$ 3.5$ billion budget, 600 schools, and 45,000 employees. The operating budgets of the New York City and Chicago districts are each larger than the entire amount most states invest in education. Corruption in education is 
significant and includes bribery, fraud, gross waste, embezzlement, nepotism, cronyism, favoritism, and other forms of misconduct (Segal, 2004).

Segal (2004) suggests estimating corruption, waste, and abuse on the basis of intensity by raising the following question: "Are they opportunistic and occasional or systemic and chronic?" Referring to Ermann and Lundman (1978), Segal (2004, p. 19) admits that some sporadic, opportunistic fraud and waste is almost inevitable in any large organization, while noting that systemic patterns suggest a deeper, constitutional problem: "What is striking about the New York City, Los Angeles, and pre-1997 Chicago school districts is how systemic and persistent corruption, waste, and abuse have been in certain non-core areas. The intensity of the problem is such that... investigators unearthed the same kinds of schemes year after year, sometimes for decades."

Corruption and lack of civic responsibility compromise the quality of schooling. Neither community involvement nor parental committees are helpful in restoring quality education. The literature on misconduct in education points to at least three important characteristics that are of interest for this study: the large size of educational systems and organizations where misconduct occurs, the systemic character of misconduct, and the role of peer pressure and oversight in preventing or perpetuating misconduct.

\section{Theoretical framework}

Changes in the characteristics in large educational organizations will not necessarily lead to the logically expected results. For instance, according to Bac (1998), increase in transparency in corrupt organizations may result in corruption increase. Methodology for future research in 
organizations and corrupt hierarchies, including higher education institutions may include cellular automation — a relatively new methodology of studying organizations. Research of corruption with the use of cellular automata is virtually nonexistent. Wirl (1998) presents basic socio-economic typologies of bureaucratic corruption and their implications as studied through the application of cellular automata.

As denoted by Wirl (1998, p. 203) based on works of Wolfram (1986, 1994), a cellular automaton is an iterating map $F$ that updates at each period $t$ the value or action of a site $i$, denoted $a(t)$, depending on the neighbors actions in period $(t-1)$ from a fixed radius $r$ into the set of possible states, which is discrete and of dimension $k,\{0,1,2, \ldots, \mathrm{k}-1\}$ :

$$
a_{i}(t)=F\left(a_{i-r}(t-1), a_{i-r+1}(t-1), \ldots, a_{i+r}(t-1)\right) .
$$

In deterministic cellular automata, the new state of a cell is determined on the basis of its actual state and states present in the neighboring cells. In the simplest case, a one-dimensional cellular automaton anticipates two possible states and a neighborhood of three cells. With two possible states and the neighborhood of three there are eight possible combinations of initial conditions and outcomes for the cell in focus. In a two-dimensional cellular automaton, cells can be positioned in hexagonal or square configurations. In a Von Neuman neighborhood, cells are influenced by their neighbors from four sides, while in a Moore neighborhood diagonal links are also involved. Hence, a Von Neuman neighborhood consists of five cells, including the cell in focus, and a Moore neighborhood consists of nine cells. Stochastic or three-dimensional cellular automata are more complex forms than one- and two-dimensional models. In stochastic models, the transition rule allows for stochastic or probabilistic distribution. In such case the model can 
indicate the next state of the cell in focus based on the probability of its changing its initial state or preserving it. Stochastic cellular automaton reflects on spatial inter-specific competition of neighboring cells for the determination of the focus' cell next stage.

Ideally, any large bureaucracy or professional organization, including those with complex hierarchical structures, can be decomposed to a simple linear one-period system. The resulting abstraction can be processed with cellular automata based on the set rules of functions. In some instances initial randomly distributed cells of types $a$ and $b$ can evolve into a homogenous state at a certain stage. In other cases, evolution will lead to a set of infinite separated simple stable or periodic structures depicting different combinations of cells $a$ and $b$.

As applied to employees' behavior in complex organizations, the initial chaotic patterns of behavior can transform into periodic patterns, homogenous state, or chaotic unorganized patterns indistinguishable from the initial patterns. Periodic patterns reflect repetitive behavior of employees. Evolution leads to emergence of complex localized structures. In this case, some very complex spatial patterns may arise and reproduce over long periods of time. Such patterns may also exhibit intriguing spatial propagation despite a perfect conservation of their shape. Thus, surprisingly complex behaviors can arise from the action of randomly distributed cells with distinct patterns of behavior and result in locally concentrated processes that are not strategically directed but rather sporadic.

\section{Methodology}

In the simplest case, a cellular automaton consists of a line of cells or, as in our case, education bureaucrats, with each cell carrying a value of zero or one. The site values evolve 
synchronously in discrete time steps according to the values of their nearest neighbors to indicate the effect of peer pressure and moral constraints. The analysis involves initial determination of educators who do and do not commit misconduct. The next step is to determine the period, or the single step, along the timeline. For instance, for educational financiers the period might be one financial year, while for teachers it might be one week or one academic year. The third step involves programming, or setting the rules according to which cellular automation is to progress. The rules include determinants of peer pressure and anticipated economic benefits from corruption. Further developments of the given methodology are in the two-dimensional cellular automata that can produce patterns with complicated boundaries (Packard and Wolfram, 1985). Cellular automata are based on iterated functions. The process of iteration, i.e. a repetitive process, allows for an infinite number of equal steps.

\section{Model of corrupt behavior}

This chapter offers the following theoretical model for application of cellular automata to misconduct in education sector and more specifically to corrupt educators. It considers educators as rational actors that calculate their expected cost and benefit of being involved in misconduct and make decisions about whether to participate in corrupt activities based on net benefits. It is assumed that net benefit from accepting a bribe or committing other possible forms of misconduct is a function of the benefits of corruption, including the size of a bribe or , the risk of being exposed and prosecuted, and the social pressure from colleagues as well as personal ethics, $Q=f(E, C, S)$. 
Models of corruption presented in economic and political science literature normally do not account for social environment and personal characteristics of educators. Specifically, rationalistic approaches to corruption formalized in such models do not give consideration to such factors as influence of the educator's colleagues, their interactions, and moral and ethical beliefs of the educator. The environment in which corruption is to take place as well as the educator's personal views on corruption will be denoted as social pressure. The task is to operationalize social pressure and include it in the consideration of corrupt behavior and decision-making regarding the support of the system. We will incorporate social pressure into the initial model of corruption and compliance with the formal and informal rules that exist in the system and simulate the educator's behavior with the help of numerical examples.

Social pressure includes peer pressure on the educator and his moral considerations. It is assumed that in corrupt organizations peer pressure works toward encouraging corruption. Higher peer pressure results in a higher probability for the educator to accept bribes and to comply with the current system. His moral considerations, however, can work in the opposite direction. Contrary to peer pressure, the educator's morality negatively impacts his willingness to accept bribes. Net social pressure is calculated by subtracting the numerical value of moral considerations from the numerical value of peer pressure. The model of decision-making based on the net benefits the educator $i$ would expect from corruption is presented in the equation below:

$$
Q_{i, t-1}=E_{i, t-1}+\left(p_{i, t-1}-m_{i, t-1}\right)-\left(d_{t-1} \times r_{t-1}\right),
$$


where $i$ denotes the educator, $E$ is the economic benefit from being involved in corruption, $d$ is the degree of punishment defined by law for a corrupt educator, $r$ is the probability of being exposed, $C$ is the total cost of being corrupt, $p$ is the peer pressure, $m$ is the moral considerations, $S$ is the net social pressure, $Q$ is the net benefit from corruption. All variables are taken in the period $t$ - 1 . If $Q<0$, then the educator will decide not to support the current system. If $Q>0$, then the educator will decide to support the current system.

Opportunity costs of working in the education sector for period $t$-1 can be equal to the educator's present salary, benefits of corruption, social pressure, and risks, associated with bribery and other forms of corruption. In this case the educator is neutral to the existing system. $\mathrm{He} /$ she neither supports the system, nor is he/she willing to change it because his/her position in terms of income and personal wealth will likely stay unchanged. The equality can be presented as follows:

$$
\mathrm{O}_{\mathrm{i}, \mathrm{t}-1}=L_{i, t-1}+E_{i, t-1}+\left(p_{i, t-1}-m_{i, t-1}\right)-\left(d_{t-1} \times r_{t-1}\right)
$$

If $O<0$, then the educator will decide not to support the current system. If $O>0$, then the educator will decide to support the system. Peer pressure is understood as a pressure of corrupt colleagues on the educator toward corruption. Such a pressure may come from other educators within the department and the administration. Accordingly, the value of $p$ is anticipated to always be positive. The state pressure on corrupt educators is exogenous and hence is not included in the initial model. The educator's moral standards are assumed to be against corruption, and hence $m$ is negative. A numerical example of defining the educator's decision of 
whether to support the system in exchange for the opportunities to collect bribes or commit misconduct without being punished is presented in Table 5.

\section{Model simulation}

Table 5 provides a numerical example for the extended model presented above (2) for the period $t$ - 1 . The assumption is made that social pressure depends on two educators who are the nearest colleagues of the educator whose decision is at stake. The educator's colleagues are denoted in the table as $i-1$ and $i+1$. Let us assume that the social pressure function takes the values 0 for deviating from the colleagues' behavior, 1 for conforming to one of the two colleagues, and 2 for a uniform corrupt behavior of all three educators. The values are obtained as results from the combination of peer pressure and moral considerations. Peer pressure is equal to 2 if both of the educator's colleagues are corrupt, 1 if only one of colleagues is corrupt, and 0 if both of colleagues do not accept bribes. Moral considerations are assigned values of 0 or 1 , depending on whether the educator already accepts bribes.

The degree of punishment for corrupt behavior is uniform for all of the possible combinations of corrupt and uncorrupt educators and has a value of 4 . The probability of being exposed depends on the corruptness of the colleagues-educators. If the educator is not corrupt, the probability of being exposed is equal to 0 only if both of his colleagues are corrupt. However, if the educator will accept a bribe while having both of his colleagues not involved in corrupt activities, the probability of being exposed is equal to 1 . Having only one of two colleagues corrupt makes the probability of being exposed equal to 0.5 . Accordingly, the value of the total cost of being corrupt varies from 0 to 2 . The value of present or legal salary of the educator $i$ is 
constant for all three periods, $t-1, t$, and $t+1$, uniform, and equal to 2 . The fair market salary or the opportunity costs of the educator $i$ is also constant for all the three periods, $t-1, t$, and $t+1$, uniform, and equal to 3 .

The value of the economic benefits from corruption is equal to 2 . It is uniform for all the possible combinations. It is assumed that bribes are collected over a certain period of time. This period of time is similar to the one over which the corrupt educator bears the risk of being exposed and prosecuted. As can bee seen from the numerical example, the degree of punishment is twice as high as the expected benefits from corruption. This encourages corrupt educators to seek safe harbors, such as highly corrupt environments. A good example of a safe harbor would be a department where most or all of the educators are corrupt.

Let us now assume that the authorities have lowered the degree of punishment that a corrupt educator may face if accused of corruption and prosecuted. We lower the existing level of punishment of 4 down to 2. A numerical example of defining the educator's decision of whether to support the existing system in exchange for the opportunities to collect benefits of corruption without being punished is presented in Table 7. 
Table 5

A numerical example of defining the educational employee's decision of whether to support the system, based on such considerations, as total benefit, costs, and social pressure, (period $t-1)$

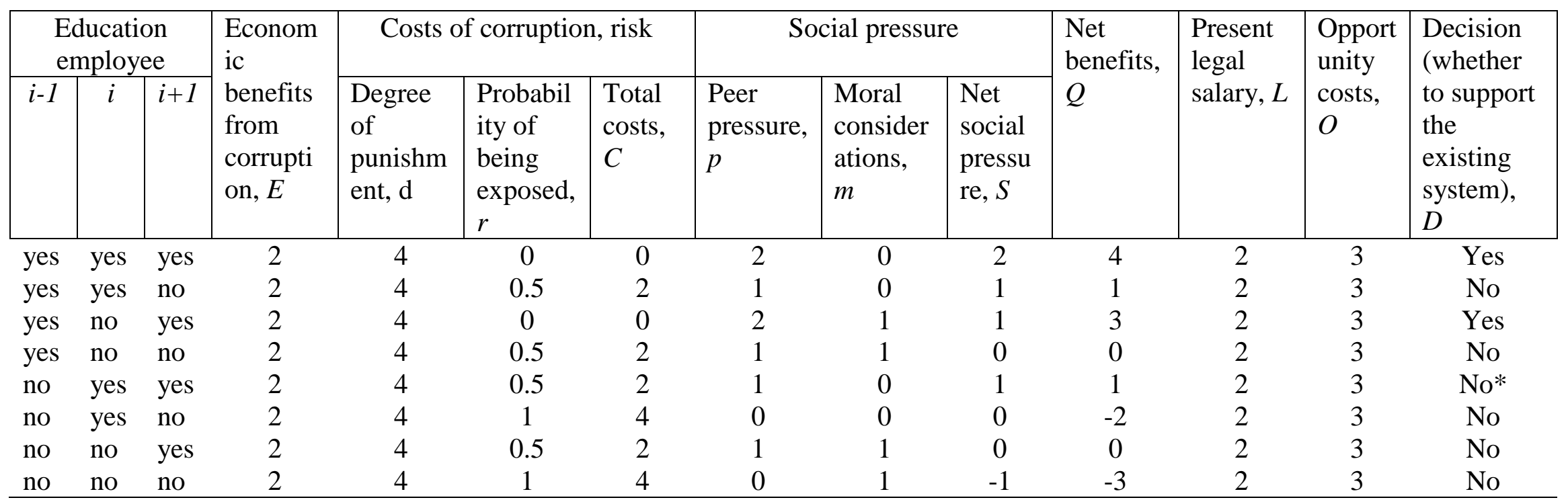

* In one case in the numerical example the opportunity costs of the educator $i$ are equal to the sum of his present salary, benefits derived from corruption, and risks that arise due to being involved in corrupt activities. Ideally, this would mean that the education employee who faces the choice of either supporting the current system or otherwise, is indifferent or neutral. The moral values are already given consideration in the example. However, as far as the educator's decision is concerned, it is marked as "No," meaning that the educator will likely decide not to support the system. This can be explained by some other external factors that are likely not to be in favor of supporting the system that allows corruption. Let us also explain it by some minimal transaction costs that might be incurred by the educator in order to accept bribes, embezzle, and extracts other benefits from corruption. 
Table 6

A numerical example of defining the educational employee's decision of whether to support the system, based on such considerations, as total benefit, costs, and social pressure, (period $t)$

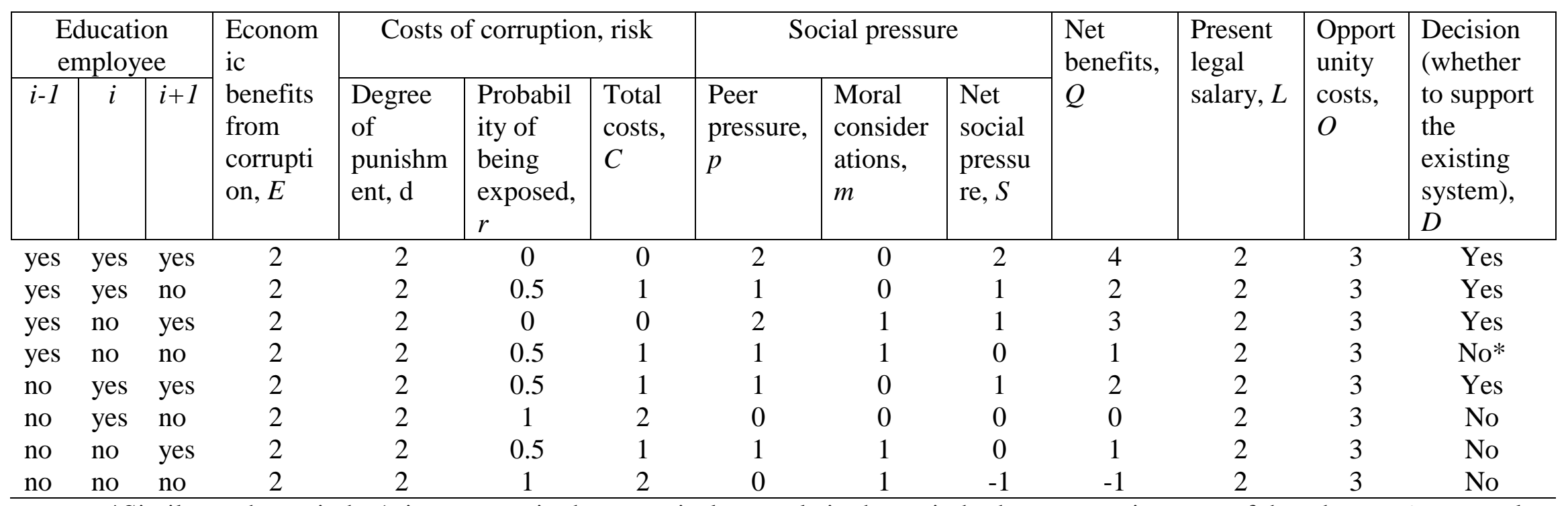

*Similar to the period $t-1$, in one case in the numerical example in the period $t$ the opportunity costs of the educator $i$ are equal to the sum of his present salary, benefits derived from corruption, and risks that arise due to being involved in corrupt activities. Accordingly, as we did in Table 1, we assume that the educator is in opposition to the existing system. 
Table 7

A numerical example of defining the educational employee's decision of whether to support the system, based on such considerations, as total benefit, costs, and social pressure, (period $t+1)$

\begin{tabular}{|c|c|c|c|c|c|c|c|c|c|c|c|c|c|}
\hline \multicolumn{3}{|c|}{$\begin{array}{l}\text { Education } \\
\text { employee }\end{array}$} & \multirow{2}{*}{$\begin{array}{l}\text { Econom } \\
\text { ic } \\
\text { benefits } \\
\text { from } \\
\text { corrupti } \\
\text { on, } E\end{array}$} & \multicolumn{3}{|c|}{ Costs of corruption, risk } & \multicolumn{3}{|c|}{ Social pressure } & \multirow{2}{*}{$\begin{array}{l}\text { Net } \\
\text { benefits, } \\
Q\end{array}$} & \multirow{2}{*}{$\begin{array}{l}\text { Present } \\
\text { legal } \\
\text { salary, } L\end{array}$} & \multirow{2}{*}{$\begin{array}{l}\text { Opport } \\
\text { unity } \\
\text { costs, } \\
O\end{array}$} & \multirow{2}{*}{$\begin{array}{l}\text { Decision } \\
\text { (whether } \\
\text { to support } \\
\text { the } \\
\text { existing } \\
\text { system), } \\
D\end{array}$} \\
\hline$i-1$ & $i$ & $i+1$ & & $\begin{array}{l}\text { Degree } \\
\text { of } \\
\text { punishm } \\
\text { ent, d }\end{array}$ & $\begin{array}{l}\text { Probabil } \\
\text { ity of } \\
\text { being } \\
\text { exposed, } \\
r\end{array}$ & $\begin{array}{l}\text { Total } \\
\text { costs, } \\
C\end{array}$ & $\begin{array}{l}\text { Peer } \\
\text { pressure, } \\
p\end{array}$ & $\begin{array}{l}\text { Moral } \\
\text { consider } \\
\text { ations, } \\
m\end{array}$ & $\begin{array}{l}\text { Net } \\
\text { social } \\
\text { pressu } \\
\text { re, } S\end{array}$ & & & & \\
\hline yes & yes & yes & 2 & 1 & 0 & 0 & 2 & 0 & 2 & 4 & 2 & 3 & Yes \\
\hline yes & no & no & 2 & 1 & 0.5 & 0.5 & 1 & 1 & 0 & 1.5 & 2 & 3 & Yes \\
\hline no & yes & yes & 2 & 1 & 0.5 & 0.5 & 1 & 0 & 1 & 2.5 & 2 & 3 & Yes \\
\hline no & yes & no & 2 & 1 & 1 & 2 & 0 & 0 & 0 & 1 & 2 & 3 & No* \\
\hline no & no & yes & 2 & 1 & 0.5 & 0.5 & 1 & 1 & 0 & 1.5 & 2 & 3 & Yes \\
\hline no & no & no & 2 & 1 & 1 & 2 & 0 & 1 & -1 & 0 & 2 & 3 & No \\
\hline
\end{tabular}

*Similar to periods $t-1$ and $t$, in one case in the numerical example in the period $t+1$ the opportunity costs of the educator $i$ are equal to the sum of his present salary, benefits derived from corruption, and risks that arise due to being involved in corrupt activities. Accordingly, as we did in Tables 1 and 2, we assume that the educator is in opposition to the existing system. 
As can be seen from Table 7, the number of cases when the educator will choose to comply with the system increased 100 percentage points, from 2 to 4 . Hence, a voluntary reduction of the degree of punishment from 4 in period $t-1$ down to 2 in period $t$ leads to a significant increase in the number of cases in which the educator will support the system.

Despite the significant increase in the number of cases when the educator will support the existing system in period $t$, it constitutes only half of all possible cases. This is not sufficient for the system that wants to sustain itself. The system can not afford an increase in the salaries it pays to college professors due to budget constraints. Nor can it facilitate an increase in the total sum of benefits educators generate from corruption. The size of bribes and the total scale and scope of bribery and other forms of corruption in education, as well as in other sectors of the economy, are mostly determined by the market forces, including consumer demand and clientele base, not by the state.

Further proliferation of the corruption and compliance policy is needed. Therefore, as follows from equations (1) and (2), the authorities are interested in the reduction of the total cost of being involved in corruption for each educator. This can be done easily since the punishment mechanism is administered by the state. While the state can not regulate the risk of exposure $r$, it can regulate the degree of punishment $d$. The degree of punishment consists of the probability of being prosecuted and sentenced and the level of punishment chosen by the state in regard to the corrupt educator. While formally the degree of punishment may be high, the actual degree of punishment $d$ may be relatively low, based on the low rate of prosecution. Furthermore, prosecution itself is a threat only for those who choose not to comply with the authorities' demands. 
Let us assume that the authorities have lowered the degree of punishment that a corrupt educator may face if accused of corruption and prosecuted. We reduce the existing level of punishment of 2 in period $t$ down to 1 in period $t+1$. A numerical example of defining the educator's decision of whether to support the system in exchange for the opportunities to collect bribes without being punished is presented in Table 7. The number of cases when the educator will chose to comply with the system's demands increased 50 percentage points, from 4 to 6 . Hence, a further voluntary reduction of the degree of punishment from 2 in period $t-1$ down to 1 lead to a significant increase in the number of cases in which the educator will opt for supporting the system.

Probability of being exposed may be a function of peer pressure. Accordingly, an increase in peer pressure may lead to a decrease in the probability of being exposed and, hence, to a further decrease in the total cost of being involved in corrupt activities. This will lead to an even higher probability of the educator being in support of the existing system.

\section{Results and interpretation}

The results of cellular automation simulation, including those obtained after analyzing the large educational organizations, are best seen as graphic depictions. They might be simple yet reliable assessments of the future developments that reflect the scale and the scope of educational misconduct. Wirl (1998, p.199) says that "Although cellular automata are very simple, deterministic machines and thus crude approximations of real, economic situations, they are capable of describing self organization and complex 
patterns (of corruption)." The images, both black and white and in color, depending upon the initial characteristics of the cells and the authors' determination, allow for visual examination of future patterns of misconduct. The structures with the clear aisles or sporadic distribution of corrupt educators point toward particular educators who are likely to commit misconduct in the future. Most interestingly, the predictions point to those members of large organizations who are most likely to be involved in misconduct after a certain period of time and yet who at the present may even be unaware of this.

We present three simulations based on distinct functions of deterministic patterns of behavior. The images appear structuralistic in nature, with dispersed triangles of different sizes, often localized in groups, with diffused and randomly distributed single cells. In all of the images generated below, black color identifies a corrupt educator, while white color identifies a non-corrupt educator. Two neighbors, one on the left and one on the right, influence their neighbor in the middle. We focus on the educator in the middle. For each function, we use 1000 educators in a one-year, i.e. 365-day period, where each cell represents a given educator in a given day.

We present three functions. Each of the functions reflects a certain balance of powers and combination of factors, including central authorities, educators, pay rates, risk of exposure, degree of punishment, and peer pressure. Based on the significance of these initial factors in each of the three cases, we formulate certain dependencies expressed as functions 1,2 , and 3 .

Function 1. (Rule 18). Let us assume that: 1. three corrupt educators grouped together cause the authorities to initiate an investigation; accordingly, the risk of punishment for being involved in misconduct increases, and as a result the educator 
refuses to participate in corruption. Hence, having two corrupt neighbors in period $t-1$ causes the educator to become non-corrupt in period $t ; 2$. having one non-corrupt neighbor causes the corrupt educator to become non-corrupt in period $t$, if he was corrupt in period $t-1 ; 3$. having two corrupt educators-neighbors causes the educator to remain non-corrupt in period $t$, because he/she reasonably expects that his/her neighbors will remain corrupt in period $t$ and that three corrupt educators will cause the authorities to initiate an investigation.

The risk will go up and the educator will have to refuse corruption; 4. having two non-corrupt neighbors causes the corrupt educator to become non-corrupt, since peer pressure in this case pushes him/her toward non-corruption. In addition, the risk of being exposed by non-corrupt peers is higher; 5. finally, having two non-corrupt neighbors in period $t-1$ causes the non-corrupt educator to remain non-corrupt in period $t$. The results of cellular automaton in for the function 1 are presented in Figures 14 through 17.

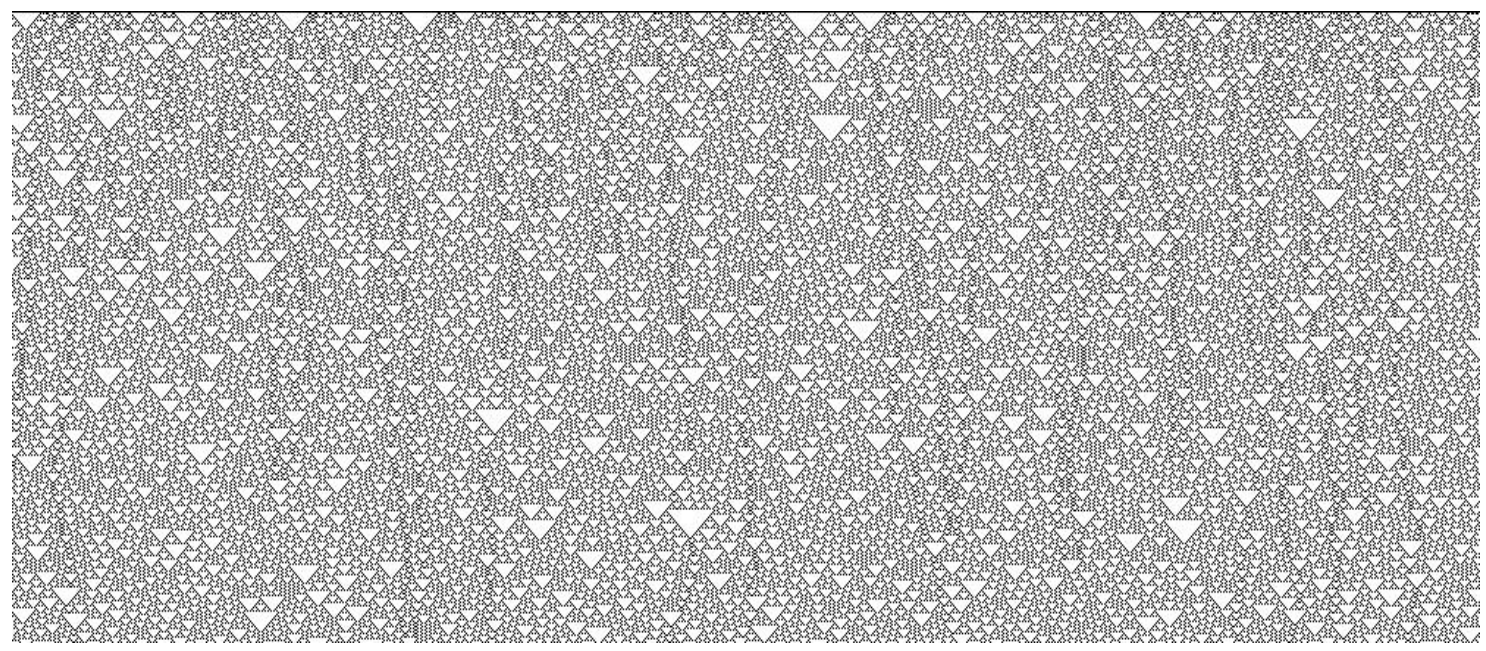

Figure 14. Function 1. Cellular automaton for 1000 educators in a 365-day period, with corrupt educators being distributed randomly in day one 


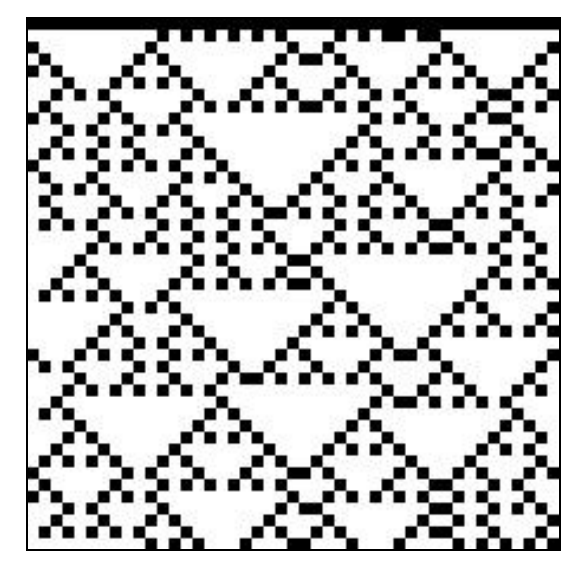

Figure 15. Function 1. Randomly selected magnified textural structure



Figure 16. Function 1. Cellular automaton for 1000 educators in a 365-day period, with one corrupt educator initially in day one 


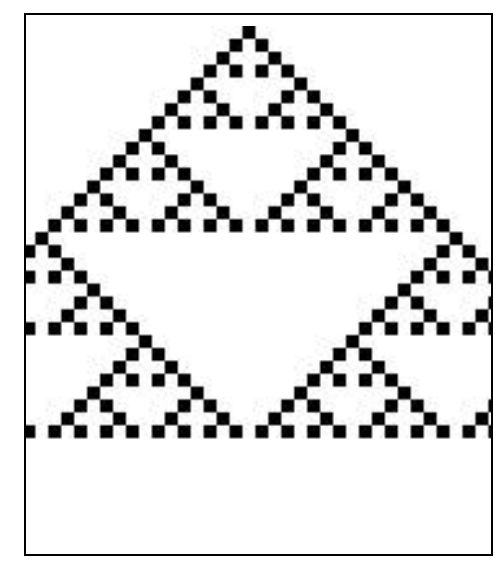

Figure 17. Function 1. Randomly selected magnified textural structure

Function 2. (Rule 126). Let us assume that: 1. three corrupt educators grouped together cause the authorities to initiate an investigation; accordingly, the risk of punishment for being involved in misconduct increases, and as a result the educator refuses to participate in corruption. Hence, having two corrupt neighbors in period $t-1$ causes the educator to become non-corrupt in period $t ; 2$. having one corrupt neighbor allows the corrupt educator to remain corrupt in period $t$, if he was corrupt in period $t-1 ; 3$. having one corrupt neighbor in period $t$ - 1 encourages the non-corrupt educator to become corrupt in period $t$; 4 . having two corrupt educators-neighbors in period $t$ - 1 allows noncorrupt educator to become corrupt in period $t$; 5 . having two non-corrupt neighbors allows the corrupt educator to remain corrupt, since peer pressure in this case is weaker and does not push him/her toward non-corruption. In addition, the risk of being exposed by non-corrupt peers is lower. 6. finally, having two non-corrupt neighbors in period $t$-1 causes the non-corrupt educator to remain non-corrupt in period $t$. The results of cellular automaton for the function 2 are presented in Figures 18 through 21. 


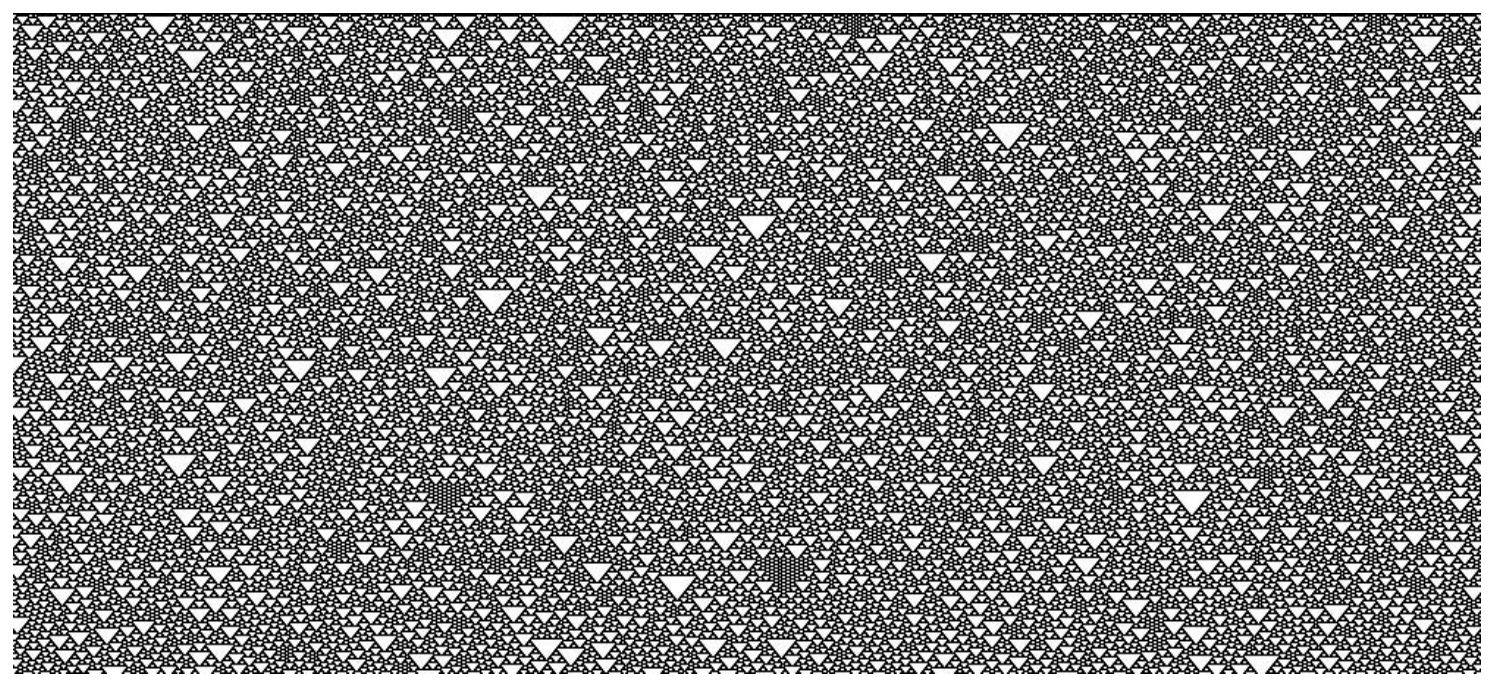

Figure 18. Function 2. Cellular automaton for 1000 educators in a 365-day period, with corrupt educators being distributed randomly in day one

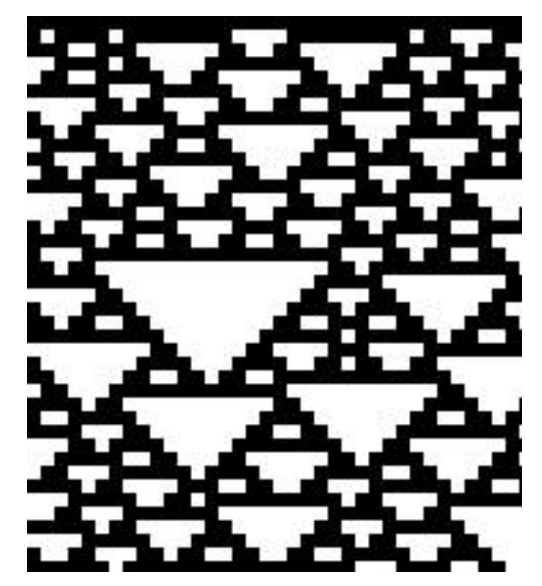

Figure 19. Function 2. Randomly selected magnified textural structure 


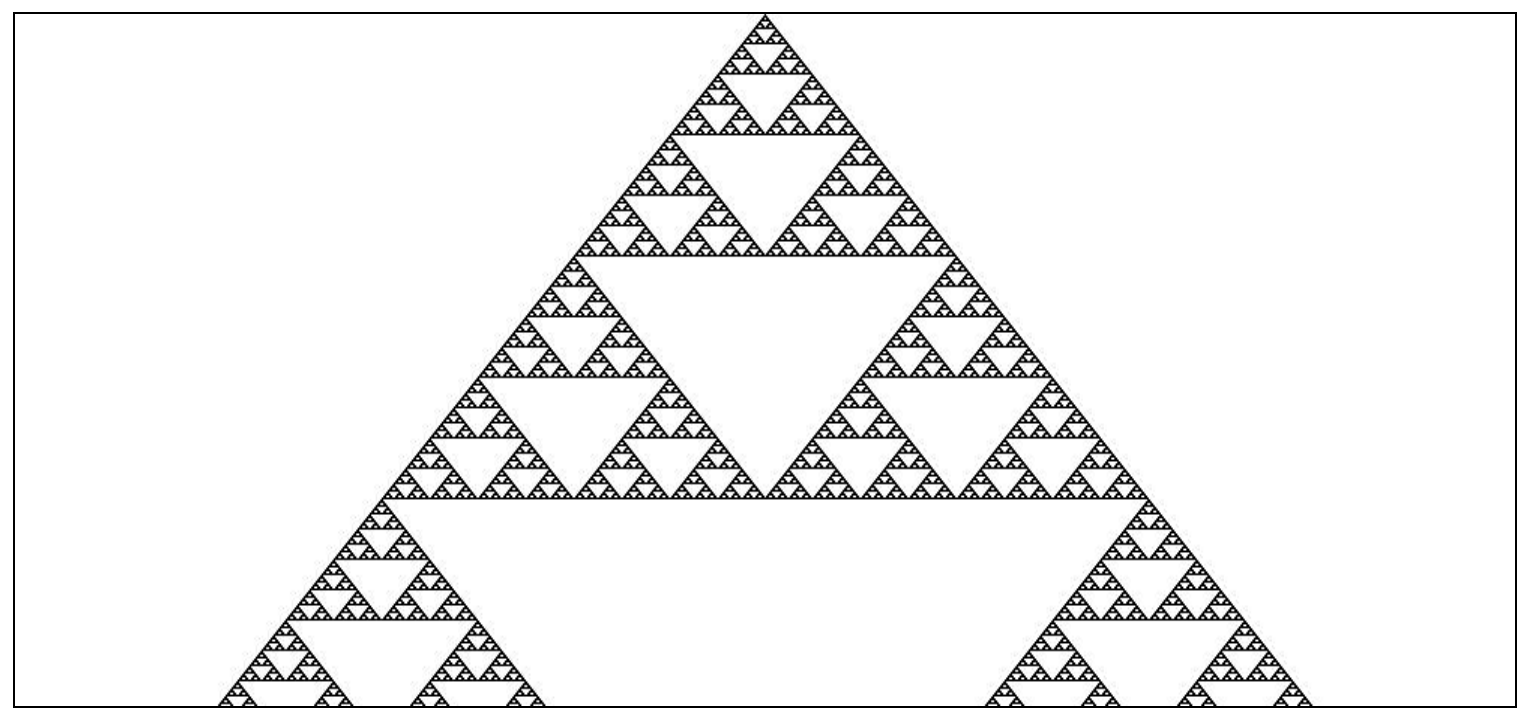

Figure 20. Function 2. Cellular automaton for 1000 educators in a 365-day period, with one corrupt educator initially in day one



Figure 21. Function 2. Randomly selected magnified textural structure

Function 3. (Rule 86). Let us assume that: 1. three corrupt educators grouped together cause the authorities to initiate an investigation; accordingly, the risk of punishment for being involved in misconduct increases, and as a result the educator refuses to participate in corruption. Hence, having two corrupt neighbors in period $t-1$ causes the educator to become non-corrupt in period $t$; 2 . having one corrupt neighbor 
causes the corrupt educator to remain corrupt in period $t ; 3$. having one corrupt neighbor causes the non-corrupt educator to become corrupt in period $t$; 4 . having two corrupt educators-neighbors in period $t$ - 1 causes the educator to remain non-corrupt in period $t$, because he/she reasonably expects that his/her neighbors will remain corrupt in period $t$ and that three corrupt educators will cause the authorities to initiate an investigation; 5 . having two non-corrupt neighbors allows the corrupt educator to remain corrupt, since peer pressure in this case is weak and does not push him/her to become non-corrupt; 6 . finally, having two non-corrupt neighbors in period $t$-1 causes the non-corrupt educator to remain non-corrupt in period $t$. The results of cellular automaton for the function 3 are presented in Figures 22 through 25.

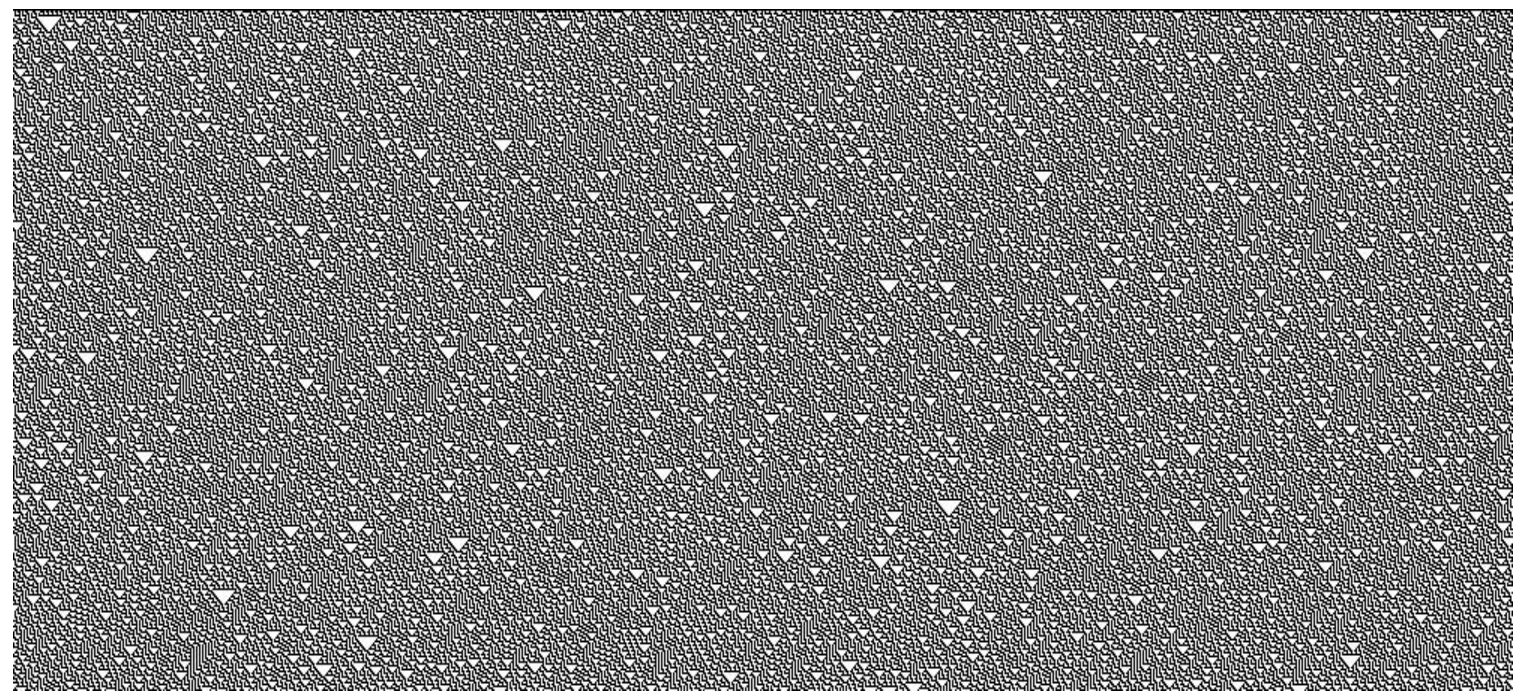

Figure 22. Function 3. Cellular automaton for 1000 educators in a 365-day period, with corrupt educators being distributed randomly in day one 


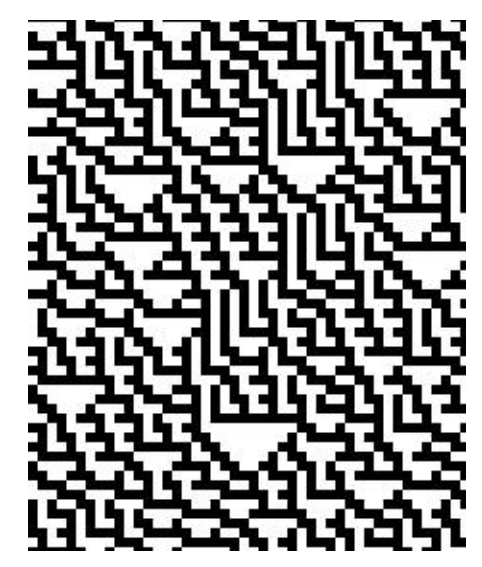

Figure 23. Function 3. Randomly selected magnified textural structure

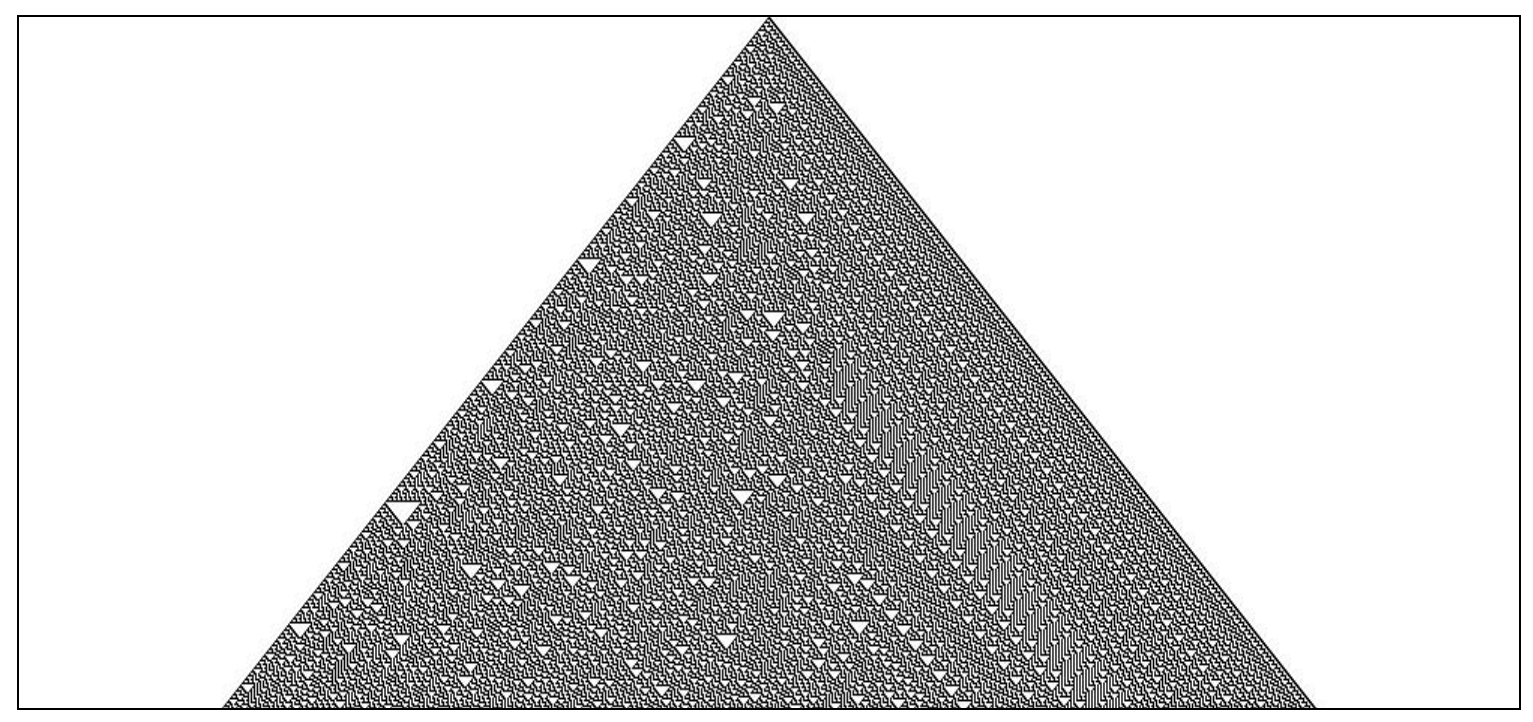

Figure 24. Function 3. Cellular automaton for 1000 educators in a 365-day period, with one corrupt educator initially in day one 


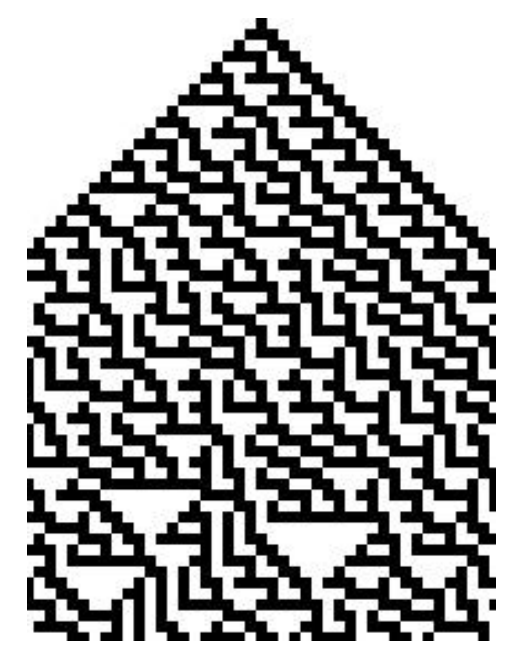

Figure 25. Function 3. Randomly selected magnified textural structure

Functions 1, 2, and 3, depicted on the images, do not necessarily correspond with the numerical examples we offered earlier. But in the essence, lesser peer pressure to be non-corrupt and the risks associated with participation in corrupt activities become definitive in educators' behavior in both numerical simulations and graphic representations. According to Function 1, the educator is unlikely to be encouraged to participate in misconduct in most of the instances. As a result, the structure of the cellular automaton for 1000 educators in a 365-day period, with corrupt educators being distributed randomly in day one and with one corrupt educator initially in day one, depicted in Figures 14 and 16, respectively, is of a lesser density than that of Function 2. Cellular automaton based on Function 2 appears to have somewhat similar structure, but is clearly denser. This means that higher peer pressure to become corrupt and lesser risk of prosecution make the number of instances of having corrupt educators is much higher.

Finally, as depicted in Figure 22, cellular automaton based on Function 3 is less chaotic and has a more structured appearance, than do cellular automata based on 
Functions 1 and 2. Figure 23 presents a quite astonishing pattern of distribution of educators' misconduct that starts from a single corrupt educator in day 1 and by the end of the year there are already a few hundred corrupt educators with a perspective of further proliferation until the margins are reached. The triangle that reflects the area of misconduct spread in the educational organization has a much higher density than the pyramidal structures in Figures 16 and 20. Equally interesting is that there is a clearly visible asymmetry in the way the cellular automaton progression is structured. The right side of the triangle and its center is structured along horizontal and vertical lines, while the left side of the equation is grouped more along the diagonal lines directed from the center parallel to the left lateral position. Cellular automaton for 1000 educators in a 730day period, with daily steps as single periods for corrupt activities and corrupt behavior to change are presented in Figures 1, 3, and 5 of Appendix C. Corrupt educators are being distributed randomly in day one. Figures 2, 4, and 6 depict cellular automata for 1000 educators in a 730-day period, with one corrupt educator initially in day one.

\section{Conclusion}

The presence of corruption in the education sector throughout the world is obvious; it is presented in scholarly work and is proven based on legal cases, surveys, interviews, and numerous publications in the media. Corruption in many national education systems has a systemic character, is endemic to the society, and often reaches epidemic proportions. Access to education, academic grades, term papers, degrees, credentials, and honors are all for sale. Educators of all ranks in many countries are 
grossly underpaid along with other public employees. They abuse their position in order to sustain themselves. Chronic underfunding, poor coordination, lack of transparency and control result in an education system riddled with all types of misconduct, from outright bribery and kickbacks to cronyism and ghost teachers, and from grand scale embezzlement and fraud to gross waste and petty theft.

This chapter presents cellular automation, a relatively new methodology to study misconduct in large educational organizations, and uses simulation to model the behavior of educators, including factors that influence their decision making. This methodology may be used beneficially for future research in organizations and corrupt hierarchies, including school districts and higher education institutions and make valid and credible forecasts.

Cellular automaton may prove to be a more effective and cost-efficient methodology than estimation of systems of partial differential equations. Research of corruption with the use of cellular automata is virtually nonexistent. Wirl (1998) presents basic socio-economic typologies of bureaucratic corruption and their implications as studied through the application of cellular automata. Computational organization theory is presented in works of Carley and Prietula (1994), Carley and Gasser (1999), as well as in the journal of Computational \& Mathematical Organization Theory. Some of the aspects of organizational corrupt structures may be studied along the lines of computational organization theory which uses computational and mathematical methods to study organizations, formulates models, and develops tools and procedures to validate organizational models. Eventually, this methodology will be used to improve educational 
organizations through an increase in their organizational effectiveness and efficiency and a reduction and future prevention of misconduct.

Cellular automaton based simulations can be used to model a wide variety of different environments and patterns of development, from corrupt practices among faculty in Tbilisi State University in the country of Georgia to education policy adoption strategies in the State of Georgia, and from distinct modes of research misconduct in large research universities and think tanks to opportunistic behavior of education bureaucrats and school teachers in large public school districts. 


\section{CONCLUSION}

The presence of corruption in the education sector throughout the world is obvious; it is presented in scholarly works and is proven based on legal cases, surveys, interviews, and numerous publications in the media. Corruption in many national educational systems has a systemic character, is endemic to the society, and often reaches epidemic proportions. Access to education, academic grades, term papers, degrees, credentials, and honors are all for sale. Educators of all ranks in many countries are grossly underpaid along with other public employees. They abuse their position in order to sustain themselves. Chronic underfunding, poor coordination, lack of transparency and control result in an education system riddled with all types of misconduct, from outright bribery and kickbacks to cronyism and ghost teachers, and from grand scale embezzlement and fraud to gross waste and petty theft.

Corruption in higher education receives good coverage in the media. The level of transparency is high enough to highlight the issue, its significance, scale and scope, and variety of forms in which it manifests itself, and inform the general public of its prevalence, patterns, and forms. Corruption in higher education, and the way it is reflected in the media, appears to be consistent with trajectory and pace of reforms that take place in higher education industry in the US, the UK, and the RF. Introduction of college fees in the UK, reduction of governmentally funded places in the RF, and the growing significance of private educational loans in the US, all lead to an increase of corruption in access to higher education.

The continuing massification of higher education with increasing enrollment rates 
in all three countries, as well as the emergence of for-profit sector, necessitate more control and coordination on the side of the government, educational institutions, and the public. Growing concerns over the quality of educational services lead to an increase in reporting bribery, fraud, cheating, plagiarism, diploma mills, breach of contract, and other forms of misconduct. The processes of internationalization and globalization of higher education put an emphasis on such aspects of corruption as credentials fraud and research fraud.

Socio-economic context of educational reforms and changes in each country leaves its print on major forms of corruption in higher education. For instance, in the RF, economic transition and sharp decline in salaries of college faculty lead to an increase in bribery and nepotism. In the US, a growing competition between higher education institutions leads to an increase in fraud associated with student financial aid. Lastly, growing levels of transparency and information flow lead to a better understanding of different forms of corruption and its scope and scale. The media plays a primary role in highlighting the issue. However, media reports are focused on corruption per se, and often on its causes, but do not offer solutions or ways in which the public can resist corruption. Furthermore, there are so-called grey areas that often left unattended. These grey areas may be unclear as whether they represent corrupt practices and whether these practices are illegal.

This study offers an analysis of court cases connected to corrupt practices in academia and related industries in order to discover the grey areas of corruption. Contrary to commonly shared beliefs, the legal provisions that exist in the US legislation, including Higher Education Act, False Claims Act, and Consumer Protection Act cover 
all the areas of possible misconduct in education: 1) corruption as related to the state (private individual bribes public official in order to obtain unduly benefits); 2) corruption as related to client and business (a client (subcontractor etc.) is abusing a business by bribing business' agent); and corruption as related to consumer and business (consumer fraud, when business deceives consumer).

The importance of the study of court cases on corruption in US higher education is threefold. First, court cases present additional lenses to study definitions and aspects of corruption in higher education that do not exist in other systems. Second, the national system of higher education with its mixture of public and private, non-profit and forprofit higher education is undergoing process of evolutionary changes that vary from state to state. The forms of corruption develop and change accordingly. Third, the US higher education shows pathways for reforms in numerous other national educational systems. Many national systems of higher education, including those of the former Soviet Bloc, undergo major changes and reforms moving toward the market-based systems that in many ways replicate higher education industry that exists in the US. Accordingly, forms of corruption that are currently present in the US education will eventually develop in the transition educational systems as well. Learning about the forms and mechanism through which corruption in US higher education perpetuates will help in predicting corruption in other national educational systems.

The processes of decentralization, marketization, commoditization, and privatization in higher education rise questions of accountability, transparency, quality, and access. Decentralized financing of higher education anticipates cost sharing based in part on educational loans. The decentralized US higher education that long been 
considered an exception among other developed nations now turns into a sector from which inferences are to be drawn. This anticipates spillovers of the problems, but not the solutions. Forms of corruption that long existed in the US education sector, including those in quality assurance through accreditation, compliance with state and federal laws, and provision of educational loans now have a perspective to develop in other educational systems as well. While the legal frame is simplistic, the system of interrelations in the higher education industry is rather complex.

This study identifies three major organizational structures with corruption, including the vertical structure, the horizontal structure, and the vertical hierarchy. The criteria selected include major characteristics, conditions or environment, degree of monopolization and distribution of discretionary power, levels of secrecy, tolerance, and transparency, predominant forms and scale. Vertical structure is taken as an initial form of organizational structure with some presence of corruption. Major characteristics of the vertical structure include absolute degree of centralization and concentration of formal authority. Corruptioners have an opportunity to draw some benefits from their position without using their authority over their subordinates. Collusion did not take place in the structure itself. The major form of corruption at that time was embezzlement when corruptioner was embezzling from the state. Usage of the embezzled funds required a certain form of external collusion.

Vertical structure transforms into horizontal structure. Major characteristics of the horizontal structure are that it exists and develops along the lines of the process of decentralization, and declining concentration of formal authority. The characteristics also include low salaries of the employees and their opportunistic behavior. The horizontal 
structure may potentially transform into the vertical hierarchy. Vertical hierarchy anticipates both formal and informal subordination. Major characteristics are absolute degree of centralization and concentration of formal and informal authority. Conditions for vertical hierarchy include unclear laws and regulations, and high risk of punishment for opposing illegal practices rather than for violating formal rules. Vertical hierarchy is the highest organizational level of corruption when corruption is institutionalized or nearinstitutionalized. This level is characterized by the delegation of corrupt functions to subordinates. Sharing and profiteering are the two dominating functions of the participants and the structure overall. Subordinates collect bribes and then channel benefits up the hierarchical ladder.

Each of the forms is not free of problems and internal conflicts. There are certain immanent and developing problems and antagonisms in each of the organizational structures. These antagonisms as well as changes in external environment push the structures to adjust and move to the next stage. In the vertical hierarchies the major conflict forms around the determination of shares in access to graft as well as distribution and redistribution of the benefits obtained from corrupt activities. Higher education has double-directed hierarchy of administrative position and academic merit, there are no pure market-based relations and market-type mechanisms in the industry, i.e. higher education has yet to be commoditized. This creates at least three possible forms of future organization of corruption, including the return to the modified vertical structure, formation of a hybrid or the mixed structure, and creation of the vertical hierarchy.

Mixed structure as a likely option of predominant corrupt organizational structure in higher education combines elements of both horizontal and vertical structures with the 
core exchanges having form of latent corruption. In the mixed structures benefits of corruption are derived without being served by the monetary exchange. Mixed structures combine for-tuition programs and government funded programs. In the modified structures for-tuition programs experience same problems as in the modified vertical structures. State-funded places in the mixed structures are distributed among the faculty members. Corruptibility of colleges and universities are used by the state to coerce academics into compliance and control the agenda in higher education.

The positive role of the state in developing and sustaining corruption is often underestimated. According to the concept presented in this chapter strengthening of the state through a vertical administrative hierarchy is exactly what is necessary to advance corrupt and coerce policy. This policy, in turn, leads to further strengthening of the state machine. The processes of sharing and profiteering create a base and strengthen vertical structure of corruption and coercion mechanism. Degree of sharing of the benefits from corruption is an indicator of strength of vertical hierarchy. Formal frame is necessary to enforce sharing and the state is utilized as a formal structure for that matter. Horizontal structure of control is utilized on the institutional level.

In the environment where everyone demonstrates rent-seeking behavior, it seems irrational to stay outside of the "mainstream" of economic development, including corruption. The government forces the instructors to seek means of financial survival and encourages them to take bribes by turning a blind eye on corrupt practices in universities. Indulgence, as a necessary detail in the mechanism of corruption and coercion, is presented here in the form of informal approval, most often expressed as opinions and views of public officials and administrators and tolerance of the general public. The 
concept of corruption and coercion applied to higher education demonstrates how state interests influence unhealthy institutional environments. Methodology for future research in large educational organizations with corrupt hierarchies may include cellular automation - a relatively new methodology of studying organizations.

This study presents cellular automation, a relatively new methodology to study misconduct in large educational organizations, and uses simulation to model the behavior of educators, including factors that influence their decision making. This methodology may be used beneficially for future research in organizations and corrupt hierarchies, including school districts and higher education institutions and make valid and credible forecasts. Cellular automaton may prove to be a more effective and cost-efficient methodology than estimation of systems of partial differential equations. Some of the aspects of organizational corrupt structures may be studied along the lines of computational organization theory which uses computational and mathematical methods to study organizations, formulates models, and develops tools and procedures to validate organizational models. Eventually, this methodology will be used to improve educational organizations through an increase in their organizational effectiveness and efficiency and a reduction and future prevention of misconduct.

This study makes a conceptual contribution to the subfield of corruption that exists in several disciplines, including political science and economics, and almost nonexistent in the field of education, and higher education policy in particular. Definition of corruption as it is used in economics underlines role of the state and assumes corruptibility of a government official. Corruption in higher education presents the need for a more inclusive definition. The challenge to the understanding of corruption as 
applied to higher education arises when one is confronted with cases of bribery. These may take place in private higher education institutions as well as in the public ones. This work formulates an operational definition of corruption in higher education as a system of informal relations established to regulate unsanctioned access to material and nonmaterial assets through abuse of the office of public or corporate trust. In this sense, corruption in higher education anticipates abuse of public trust by certain participating groups or individuals-participants of educational process in a broad sense, and processes, closely related to educational process, such as research, selection of students, funding, use of public property etc. This work considers corruption as it implies illegality or a precedent and at the same time does not limit its area of investigation by the legal definition of corruption only.

Multidisciplinary character of the performed study gives it a certain value in such fields as political science, development economics, economics of transition, economic sociology, and legal studies. Major findings of the study may be utilized in different areas of public policy, educational policy, educational planning, and university management. Results of the study may be used for the development and implementation of measures necessary for prevention of corruption in higher education industries in countries with different systems of higher education. The results can also be used in teaching such disciplines as Comparative and International Education Policy, Finance in Higher Education, and College and University Administration. 
Appendix A

NOTICE OF INTENTION TO SUE (LETTER)

Dear Ms. Briones:

You are hereby notified that the Attorney General intends to commence litigation against

Education Finance Partners ("EFP”) pursuant to Executive Law Section 63(12) and Article 22-A of the General Business Law ("GBL"), Sections 349 and 350, to enjoin unlawful and deceptive acts and practices in which EFP has engaged and continues to engage, and to obtain injunctive relief, restitution, damages, and such other relief as the Court may deem just and proper.

The unlawful and deceptive acts and practices complained of arise out of EFP's student loan business. EFP has repeatedly and persistently offered to make payments, and has in fact made payments, to colleges, universities, and vocational schools ("Schools") in exchange for those Schools (a) steering students to EFP loan products, and (b) placing EFP on the Schools' "preferred lender" lists. Among the Schools with which EFP has had such revenue sharing agreements are: Baylor University, Boston University, Clemson University, Drexel University, Duquesne University, Fordham University, Long Island University, Pepperdine University - Graziado School of Business, St. John's University, Texas Christian University, Washington University in St. Louis, and the University of Mississippi. In total, EFP has or has had such agreements with more than 60 schools across the nation. 
The agreements entered into by EFP require the Schools to promote EFP to its students as a "preferred private loan provider via the school's website, printed lender list, mailings, and other marketing opportunities to both first-time and serial borrowers who are candidates for a private loan." In return, the agreements require EFP to pay back to the school a percentage of the net value of the loans referred by each school. For example, EFP's agreement with Duquesne University provides that the school will receive 60 basis points (.6\%) of the net value of all referred loans. Some of the agreements are "tiered" so as to provide increasing financial incentives for the schools as more students take loans from EFP. EFP's agreement with Boston University, for example, provides that the school will receive 25 basis points (.25\%) of the net value of referred loans of at least $\$ 1,000,000$ up to $\$ 5,000,000 ; 50$ basis points (.5\%) of the net value of referred loans between $\$ 5,000,000$ and $\$ 10,000,000$; and 75 basis points $(.75 \%)$ of the net value of referred loans over $\$ 10,000,000$. In at least one instance (Drexel University), the agreement provides for EFP to be the exclusive preferred lender, resulting in the school's pushing its students towards EFP and EFP alone. Thus, Drexel's agreement with EFP, dated April 1,2006, provides that Drexel has agreed to make EFP its "sole preferred private loan provider," in consideration for which EFP has agreed that Drexel will receive 75 basis points (.75\%) of the net value of referred loans between $\$ 1$ and $\$ 24,999,999$; and 100 basis point (1\%) of all loan amounts of $\$ 25,000,000$ or greater.

Such steering and placement on the preferred lender lists occurred without disclosure to the student borrowers and their parents of the payments and offers to pay, and had the potential to mislead the student borrowers and their parents. The arrangement created unlawful conflicts of interest on the part of the Schools. To avoid these inherent 
conflicts of interest, EFP must sever its financial ties with the Schools to whose students it makes loans. It must compete for the students' loans by offering the best loan products to students, not the best kickbacks to the Schools.

EFP has also repeatedly and persistently engaged in misleading and deceptive business practices and false advertising by falsely representing, directly and by implication, that Schools endorse EFP's loan products and recommend those products for individual student borrowers. Specifically, EFP has (I) used Schools' names, logos, colors, and mascots in EFP's correspondence and on EFP's web-based promotional materials, creating the false impression that the Schools have endorsed EFP7s products, and (ii) provided Schools with EFP promotional materials for insertion into the Schools' financial aid award packages and tuition cost of attendance bills, again creating the false impression that the Schools have endorsed EFP's products.

Retrieved May 21, 2007, from

http://www.oag.state.ny.us/press/2007/mar/EFP\%20Final\%20Letter.pdf 


\section{Appendix B}

Everyday corruption practice in the Russian Federation

Table 1

Everyday all-Russian corruption market characteristics in the Russian Federation, 2001 and 2005

\begin{tabular}{|l|r|r|}
\hline \multicolumn{1}{|c|}{ Corruption characteristics } & 2001 & 2005 \\
\hline $\begin{array}{l}\text { Corruption coverage (share of citizens captured by the } \\
\text { corruption, \%) }\end{array}$ & 50.40 & 54.9 \\
\hline \begin{tabular}{l} 
Corruption risk (risk to face the necessity to pay a bribe, \%) \\
\hline Corruption demand (readiness to bribe, \%)
\end{tabular} & 25.70 & 35.0 \\
\hline $\begin{array}{l}\text { Corruption intensity (average number of bribes per annum for } \\
\text { bribers) }\end{array}$ & 1.19 & 0.882 \\
\hline \begin{tabular}{l} 
Average bribe amount for bribers (rubles) \\
\hline $\begin{array}{l}\text { Average bribe portion within cost of living (for 2001 and 2004 } \\
\text { respectively) }\end{array}$
\end{tabular} & 1817.00 & 2780 \\
\hline Average annual contribution for a briber (rubles) & 2162.00 & 2452 \\
\hline Annual volume of the everyday corruption market (US\$ billion) & 2.825 & 3.014 \\
\hline
\end{tabular}

Corruption coverage is the share of citizens captured (even once) by the corruption situation irrespective of its outcome: whether in this case they have bribed or not.

Corruption risk is the share of citizens' entrapment into some corruption situation due to any problems. The corruption risk may be seen as an index of the authorities' corruption pressure upon citizens. 
Corruption demand (readiness to bribe) is the share of cases when an average citizen bribes under corruption situation. The corruption demand may be seen as an index of the citizens' readiness to use corruption methods so that to solve its problems or some readiness to fall under authorities' corruption pressure.

Corruption intensity is the average number of bribes per annum for a single arbitrary briber in this given year.

Average bribe amount is the average bribe sum per a single arbitrary corruption deal in this given year.

Average annual contribution is the average annual costs of a single arbitrary briber in this given year. This rate may be determined as product of the corruption intensity by an average bribe amount.

Annual market volume is the evaluation (from the bottom) of the total turnover for corruption market as an entire sum of any bribes to be paid by all bribers annually.

These characteristics (probably besides the item of corruption coverage) may be calculated for both total national everyday corruption market and individual and special markets of any everyday corruption (see below). For instance, any bribes related to the medical services form a special market of the everyday corruption.

Thus, the total everyday corruption market displays its stable position. The average bribe value in its real form may even shows its slight decrease. But the registered difference may be quite compensated for by metering error. Although this dynamic stability is formed by mutual action of the two opposite tendencies: the authorities intensify its corruption pressure upon citizens and in response the citizens lower is corruption demand. 
Source: Corruption Process in Russia: Level, Structure, Trends. In G. Satarov

(Ed.). Diagnostics of Corruption in Russia: 2001-2005. INDEM Foundation. Retrieved

May 12, 2006, from http://www.indem.ru/en/publicat/2005diag_engV.htm

Table 2

Special everyday corruption market characteristics in the Russian Federation, 2001 and 2005

\begin{tabular}{|c|c|c|c|c|}
\hline \multirow[t]{2}{*}{ Problem (everyday corruption market) } & \multicolumn{2}{|c|}{$\begin{array}{l}\text { Corruption } \\
\text { risk }\end{array}$} & \multicolumn{2}{|c|}{$\begin{array}{l}\text { Corruption } \\
\text { demand } \\
\text { (readiness to } \\
\text { bribe) }\end{array}$} \\
\hline & 2001 & 2005 & 2001 & 2005 \\
\hline Free medical service (outpatient clinic, hospital) & 23.5 & 37.7 & 80.4 & 62.0 \\
\hline $\begin{array}{l}\text { School: to enter the school and to finish successfully, } \\
\text { education process }\end{array}$ & 13.2 & 41.0 & 76.2 & 60.8 \\
\hline $\begin{array}{l}\text { Higher education institution: to enter HEI, transfer to } \\
\text { another HEI, course examinations, term papers, midterms, } \\
\text { theses, etc. }\end{array}$ & 36.0 & 52.1 & 66.7 & 63.2 \\
\hline Pensions: paperwork, calculations, etc. & 11.3 & 11.4 & 50.0 & 17.1 \\
\hline Social payments: paperwork, calculations, etc. & 16.2 & 19.8 & 47.4 & 30.6 \\
\hline $\begin{array}{l}\text { Solving problems related to the conscription procedure } \\
\text { (military draft) }\end{array}$ & 32.6 & 57.7 & 50.0 & 63.4 \\
\hline Employment: to get a required job or career development & 24.6 & 29.2 & 80.0 & 35.0 \\
\hline $\begin{array}{l}\text { Land: to obtain some territory (for a country cottage or } \\
\text { farming) }\end{array}$ & 14.9 & 39.8 & 75.0 & 51.1 \\
\hline $\begin{array}{l}\text { Dwelling: to obtain and/or legalize a relevant proprietary } \\
\text { interest }\end{array}$ & 28.9 & 34.3 & 75.6 & 41.9 \\
\hline To get dwelling maintenance and repair work services & 32.2 & 29.5 & 60.5 & 31.6 \\
\hline To obtain justice in court & 26.2 & 39.5 & 59.4 & 43.6 \\
\hline To get assistance and protection from police & 27.4 & 40.2 & 77.3 & 54.7 \\
\hline $\begin{array}{l}\text { To get registration, domestic or foreign passport at the } \\
\text { place of residence }\end{array}$ & 19.7 & 32.7 & 76.0 & 48.9 \\
\hline $\begin{array}{l}\text { To solve problems with road police authorities (obtaining } \\
\text { driver's license, technical examination, minor traffic } \\
\text { violations) }\end{array}$ & 59.3 & 59.6 & 86.0 & 68.9 \\
\hline
\end{tabular}

Source: Composed from Corruption Process in Russia: Level, Structure, Trends.

In G. Satarov (Ed.). Diagnostics of Corruption in Russia: 2001-2005. INDEM

Foundation. Retrieved May 12, 2006, from

http://www.indem.ru/en/publicat/2005diag_engV.htm 
Table 3

Dynamics of the special everyday corruption markets' annual volumes in the Russian Federation, 2001 and 2005

\begin{tabular}{|c|c|c|c|c|}
\hline Problem (everyday corruption market) & \multicolumn{2}{|c|}{$\begin{array}{l}\text { Market size, } \\
\text { million USD }\end{array}$} & \multicolumn{2}{|c|}{$\begin{array}{l}\text { Total market } \\
\text { share }\end{array}$} \\
\hline & 2001 & 2005 & 2001 & 2005 \\
\hline Free medical service (outpatient clinic, hospital) & 602.41 & 401.10 & 0.2870 & 0.148 \\
\hline $\begin{array}{l}\text { School: to enter the school and to finish } \\
\text { successfully, education process }\end{array}$ & 70.10 & 92.40 & 0.0333 & 0.034 \\
\hline $\begin{array}{l}\text { Higher education institution: to enter HEI, transfer to } \\
\text { another HEI, course examinations, term papers, } \\
\text { midterms, theses, etc. }\end{array}$ & 449.37 & 583.40 & 0.2138 & 0.215 \\
\hline Pensions: paperwork, calculations, etc. & 0.29 & 7.90 & 0.0001 & 0.003 \\
\hline Social payments: paperwork, calculations, etc. & 6.62 & 80.30 & 0.0031 & 0.030 \\
\hline $\begin{array}{l}\text { Solving problems related to the conscription } \\
\text { procedure (military draft) }\end{array}$ & 12.66 & 353.60 & 0.0060 & 0.130 \\
\hline $\begin{array}{l}\text { Employment: to get a required job or career } \\
\text { development }\end{array}$ & 56.16 & 143.40 & 0.0267 & 0.053 \\
\hline $\begin{array}{l}\text { Land: to obtain some territory (for a country cottage } \\
\text { or farming) }\end{array}$ & 20.09 & 84.40 & 0.0096 & 0.031 \\
\hline $\begin{array}{l}\text { Dwelling: to obtain and/or legalize a relevant } \\
\text { proprietary interest }\end{array}$ & 123.02 & 298.60 & 0.0585 & 0.110 \\
\hline $\begin{array}{l}\text { To get dwelling maintenance and repair work } \\
\text { services }\end{array}$ & 22.67 & 15.60 & 0.0108 & 0.006 \\
\hline To obtain justice in court & 274.48 & 209.50 & 0.1306 & 0.077 \\
\hline To get assistance and protection from police & 29.95 & 29.60 & 0.0142 & 0.011 \\
\hline $\begin{array}{l}\text { To get registration, domestic or foreign passport at } \\
\text { the place of residence }\end{array}$ & 65.84 & 87.70 & 0.0313 & 0.032 \\
\hline $\begin{array}{l}\text { To solve problems with road police authorities } \\
\text { (obtaining driver's license, technical examination, } \\
\text { minor traffic violations) }\end{array}$ & 368.38 & 183.30 & 0.1752 & 0.068 \\
\hline
\end{tabular}

Source: Composed from Corruption Process in Russia: Level, Structure, Trends. In G. Satarov (Ed.). Diagnostics of Corruption in Russia: 2001-2005. INDEM Foundation. Retrieved May 12, 2006, from http://www.indem.ru/en/publicat/2005diag_engV.htm 
Table 4

Dynamics of the average bribe amount (in rubles) by sector in the Russian Federation, 2001 and 2005

\begin{tabular}{|c|c|c|c|c|c|}
\hline \multirow[t]{2}{*}{ Problem (everyday corruption market) } & \multicolumn{2}{|c|}{ Value } & \multicolumn{2}{|c|}{ Rank* } & \multirow{2}{*}{$\begin{array}{c}\text { change } \\
\%\end{array}$} \\
\hline & 2001 & 2005 & 2001 & 2005 & \\
\hline $\begin{array}{l}\text { Free medical service (outpatient clinic, } \\
\text { hospital) }\end{array}$ & 1093 & 1423 & 8 & 11 & 0.57 \\
\hline $\begin{array}{l}\text { School: to enter the school and to finish } \\
\text { successfully, education process }\end{array}$ & 1238 & 2312 & 7 & 8 & 1.64 \\
\hline $\begin{array}{l}\text { Higher education institution: to enter HEI, } \\
\text { transfer to another HEI, course examinations, } \\
\text { term papers, midterms, theses, etc. }\end{array}$ & 4305 & 3869 & 2 & 4 & -0.19 \\
\hline Pensions: paperwork, calculations, etc. & 50 & 2250 & 14 & 9 & - \\
\hline $\begin{array}{l}\text { Social payments: paperwork, calculations, } \\
\text { etc. }\end{array}$ & 250 & 3467 & 13 & 6 & - \\
\hline $\begin{array}{l}\text { Solving problems related to the conscription } \\
\text { procedure (military draft) }\end{array}$ & 3250 & 15409 & 3 & 1 & 7.06 \\
\hline $\begin{array}{l}\text { Employment: to get a required job or career } \\
\text { development }\end{array}$ & 963 & 2448 & 9 & 7 & 2.91 \\
\hline $\begin{array}{l}\text { Land: to obtain some territory (for a country } \\
\text { cottage or farming) }\end{array}$ & 2000 & 3713 & 5 & 5 & 1.62 \\
\hline $\begin{array}{l}\text { Dwelling: to obtain and/or legalize a relevant } \\
\text { proprietary interest }\end{array}$ & 2529 & 5548 & 4 & 3 & 2.25 \\
\hline $\begin{array}{l}\text { To get dwelling maintenance and repair work } \\
\text { services }\end{array}$ & 292 & 400 & 12 & 14 & 0.70 \\
\hline To obtain justice in court & 13964 & 9570 & 1 & 2 & -0.59 \\
\hline To get assistance and protection from police & 1715 & 930 & 6 & 12 & -0.86 \\
\hline $\begin{array}{l}\text { To get registration, domestic or foreign } \\
\text { passport at the place of residence }\end{array}$ & 664 & 1426 & 11 & 10 & 2.17 \\
\hline $\begin{array}{l}\text { To solve problems with road police } \\
\text { authorities (obtaining driver's license, } \\
\text { technical examination, minor traffic } \\
\text { violations) }\end{array}$ & 896 & 920 & 10 & 13 & 0.05 \\
\hline
\end{tabular}

Source: Composed from Corruption Process in Russia: Level, Structure, Trends.

In G. Satarov (Ed.). Diagnostics of Corruption in Russia: 2001-2005. INDEM

Foundation. Retrieved May 12, 2006, from

http://www.indem.ru/en/publicat/2005diag_engV.htm

* The rank 1 is assigned to the sector based on the largest average bribe. 
Table 5

Dynamics of the corruption intensity within various everyday corruption markets by sector in the Russian Federation, 2001 and 2005

\begin{tabular}{|c|c|c|c|c|c|}
\hline \multirow[t]{2}{*}{ Problem (everyday corruption market) } & \multicolumn{2}{|c|}{ Value } & \multicolumn{2}{|c|}{ Rank* } & \multirow{2}{*}{$\begin{array}{c}\text { change } \\
\%\end{array}$} \\
\hline & 2001 & 2005 & 2001 & 2005 & \\
\hline $\begin{array}{l}\text { Free medical service (outpatient clinic, } \\
\text { hospital) }\end{array}$ & 1.098 & 0.847 & 4 & 7 & 0.883 \\
\hline $\begin{array}{l}\text { School: to enter the school and to finish } \\
\text { successfully, education process }\end{array}$ & 2.213 & 0.950 & 1 & 5 & 2.205 \\
\hline $\begin{array}{l}\text { Higher education institution: to enter HEI, } \\
\text { transfer to another HEI, course examinations, } \\
\text { term papers, midterms, theses, etc. }\end{array}$ & 0.820 & 0.875 & 10 & 6 & -0.259 \\
\hline Pensions: paperwork, calculations, etc. & 0.669 & 0.339 & 13 & 14 & 1.906 \\
\hline Social payments: paperwork, calculations, etc. & 1.065 & 0.657 & 6 & 12 & 1.480 \\
\hline $\begin{array}{l}\text { Solving problems related to the conscription } \\
\text { procedure (military draft) }\end{array}$ & 1.010 & 0.650 & 7 & 13 & 1.377 \\
\hline $\begin{array}{l}\text { Employment: to get a required job or career } \\
\text { development }\end{array}$ & 0.950 & 1.053 & 8 & 2 & -0.419 \\
\hline $\begin{array}{l}\text { Land: to obtain some territory (for a country } \\
\text { cottage or farming) }\end{array}$ & 0.655 & 0.698 & 14 & 10 & -0.254 \\
\hline $\begin{array}{l}\text { Dwelling: to obtain and/or legalize a relevant } \\
\text { proprietary interest }\end{array}$ & 0.848 & 0.809 & 9 & 8 & 0.178 \\
\hline $\begin{array}{l}\text { To get dwelling maintenance and repair work } \\
\text { services }\end{array}$ & 0.771 & 0.954 & 11 & 4 & -0.917 \\
\hline To obtain justice in court & 0.681 & 0.672 & 12 & 11 & 0.051 \\
\hline To get assistance and protection from police & 1.787 & 0.809 & 2 & 9 & 2.115 \\
\hline $\begin{array}{l}\text { To get registration, domestic or foreign } \\
\text { passport at the place of residence }\end{array}$ & 1.107 & 1.030 & 3 & 3 & 0.269 \\
\hline $\begin{array}{l}\text { To solve problems with road police authorities } \\
\text { (obtaining driver's license, technical } \\
\text { examination, minor traffic violations) }\end{array}$ & 1.089 & 1.120 & 5 & 1 & -0.110 \\
\hline
\end{tabular}

Source: Composed from Corruption Process in Russia: Level, Structure, Trends.

In G. Satarov (Ed.). Diagnostics of Corruption in Russia: 2001-2005. INDEM

Foundation. Retrieved May 12, 2006, from

http://www.indem.ru/en/publicat/2005diag_engV.htm .

* The rank 1 is assigned to the market with the most intensified corruption activities. 
Table 6

Dynamics of the demand for public services in various corrupt markets (percent) in Russian Federation, 2001 and 2005

\begin{tabular}{|c|c|c|c|c|c|}
\hline \multirow[t]{2}{*}{ Problem (everyday corruption market) } & \multicolumn{2}{|c|}{ Value } & \multicolumn{2}{|c|}{ Rank* } & \multirow{2}{*}{$\begin{array}{l}\text { Change, } \\
\text { percent }\end{array}$} \\
\hline & 2001 & 2005 & 2001 & 2005 & \\
\hline $\begin{array}{l}\text { Free medical service (outpatient clinic, } \\
\text { hospital) }\end{array}$ & 16.1 & 23.6 & 1 & 1 & 46.6 \\
\hline $\begin{array}{l}\text { School: to enter the school and to finish } \\
\text { successfully, education process }\end{array}$ & 6.1 & 2.9 & 9 & 12 & -52.5 \\
\hline $\begin{array}{l}\text { Higher education institution: to enter HEI, } \\
\text { transfer to another HEI, course examinations, } \\
\text { term papers, midterms, theses, etc. }\end{array}$ & 8.1 & 7.4 & 4 & 6 & -8.6 \\
\hline Pensions: paperwork, calculations, etc. & 7.1 & 7.0 & 6 & 8 & -1.4 \\
\hline $\begin{array}{l}\text { Social payments: paperwork, calculations, } \\
\text { etc. }\end{array}$ & 7.4 & 10.2 & 5 & 2 & 37.8 \\
\hline $\begin{array}{l}\text { Solving problems related to the conscription } \\
\text { procedure (military draft) }\end{array}$ & 4.6 & 1.8 & 13 & 14 & -60.9 \\
\hline $\begin{array}{l}\text { Employment: to get a required job or career } \\
\text { development }\end{array}$ & 6.4 & 8.5 & 8 & 3 & 32.8 \\
\hline $\begin{array}{l}\text { Land: to obtain some territory (for a country } \\
\text { cottage or farming) }\end{array}$ & 4.0 & 3.1 & 14 & 11 & -22.5 \\
\hline $\begin{array}{l}\text { Dwelling: to obtain and/or legalize a relevant } \\
\text { proprietary interest }\end{array}$ & 5.3 & 8.0 & 11 & 4 & 50.9 \\
\hline $\begin{array}{l}\text { To get dwelling maintenance and repair work } \\
\text { services }\end{array}$ & 8.8 & 7.6 & 3 & 5 & -13.6 \\
\hline To obtain justice in court & 4.8 & 2.8 & 12 & 13 & -41.7 \\
\hline To get assistance and protection from police & 5.6 & 3.4 & 10 & 10 & -39.3 \\
\hline $\begin{array}{l}\text { To get registration, domestic or foreign } \\
\text { passport at the place of residence }\end{array}$ & 6.4 & 7.0 & 7 & 7 & 9.4 \\
\hline $\begin{array}{l}\text { To solve problems with road police } \\
\text { authorities (obtaining driver's license, } \\
\text { technical examination, minor traffic } \\
\text { violations) }\end{array}$ & 9.3 & 6.7 & 2 & 9 & -28.0 \\
\hline
\end{tabular}

Source: Composed from Corruption Process in Russia: Level, Structure, Trends. In G. Satarov (Ed.). Diagnostics of Corruption in Russia: 2001-2005. INDEM Foundation. Retrieved May 12, 2006, from http://www.indem.ru/en/publicat/2005diag_engV.htm

* The rank 1 is assigned to the segment of the public services market with the highest demand. 
Appendix C

Results of Cellular Automaton 


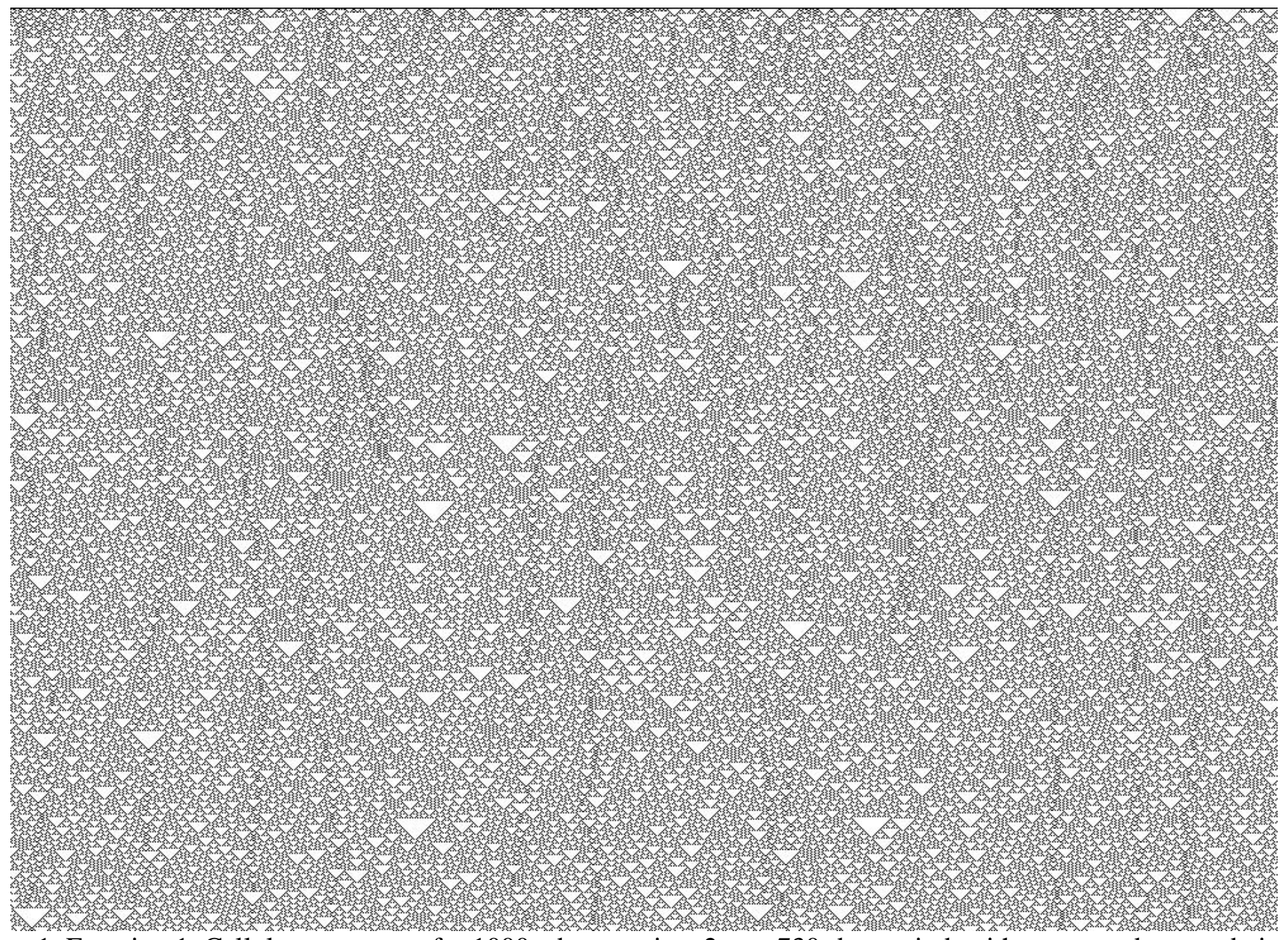

Figure 1. Function 1. Cellular automaton for 1000 educators in a 2-year730-day period, with corrupt educators being

distributed randomly in day one 


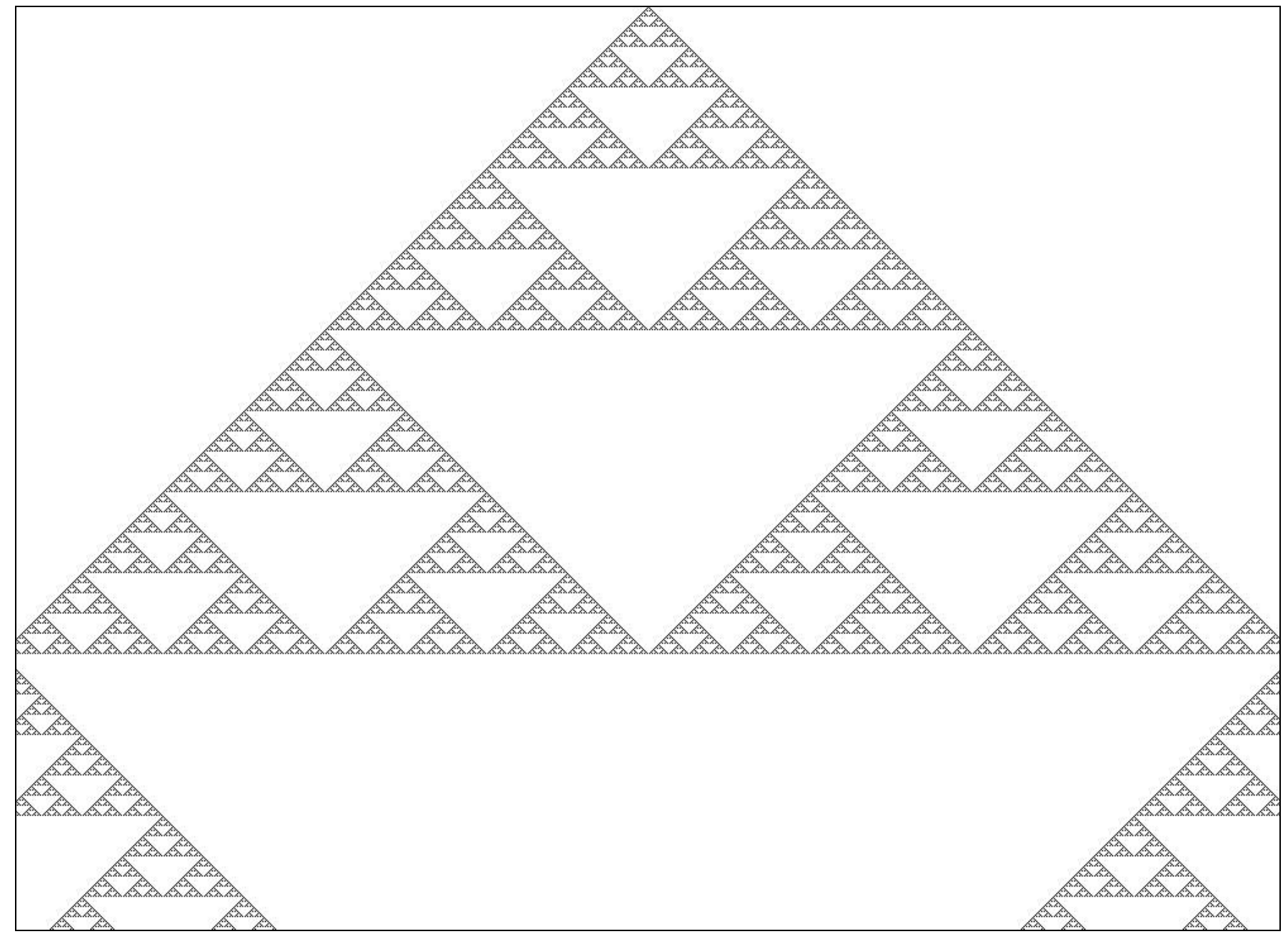

Figure 2. Function 1. Cellular automaton for 1000 educators in a 2-year730-day period, with one corrupt educator initially in day one 




Figure 3. Function 2. Cellular automaton for 1000 educators in a 2-year730-day period, with corrupt educators being distributed randomly in day one 


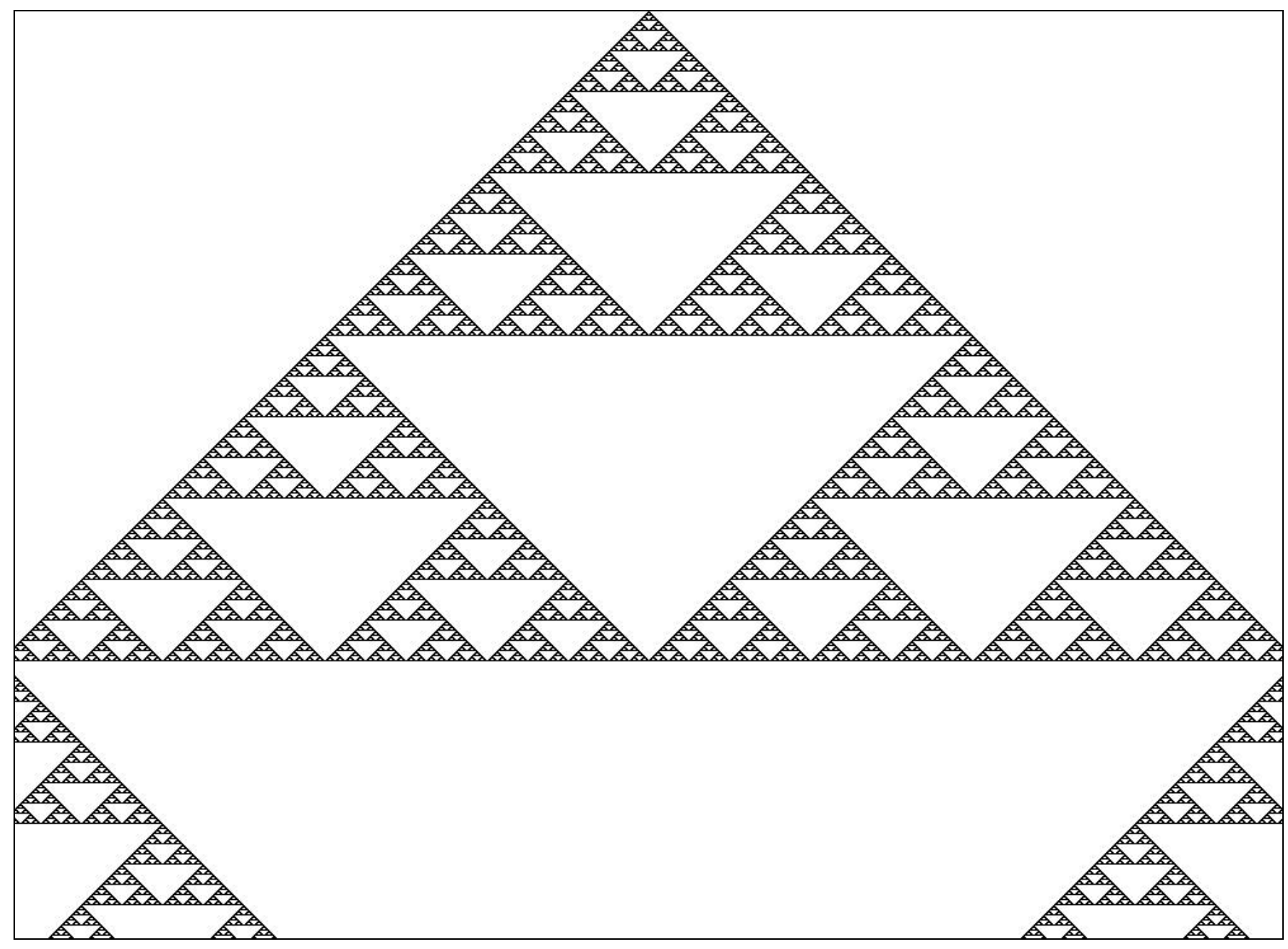

Figure 4. Function 2. Cellular automaton for 1000 educators in a 2-year730-day period, with one corrupt educator initially in day one 


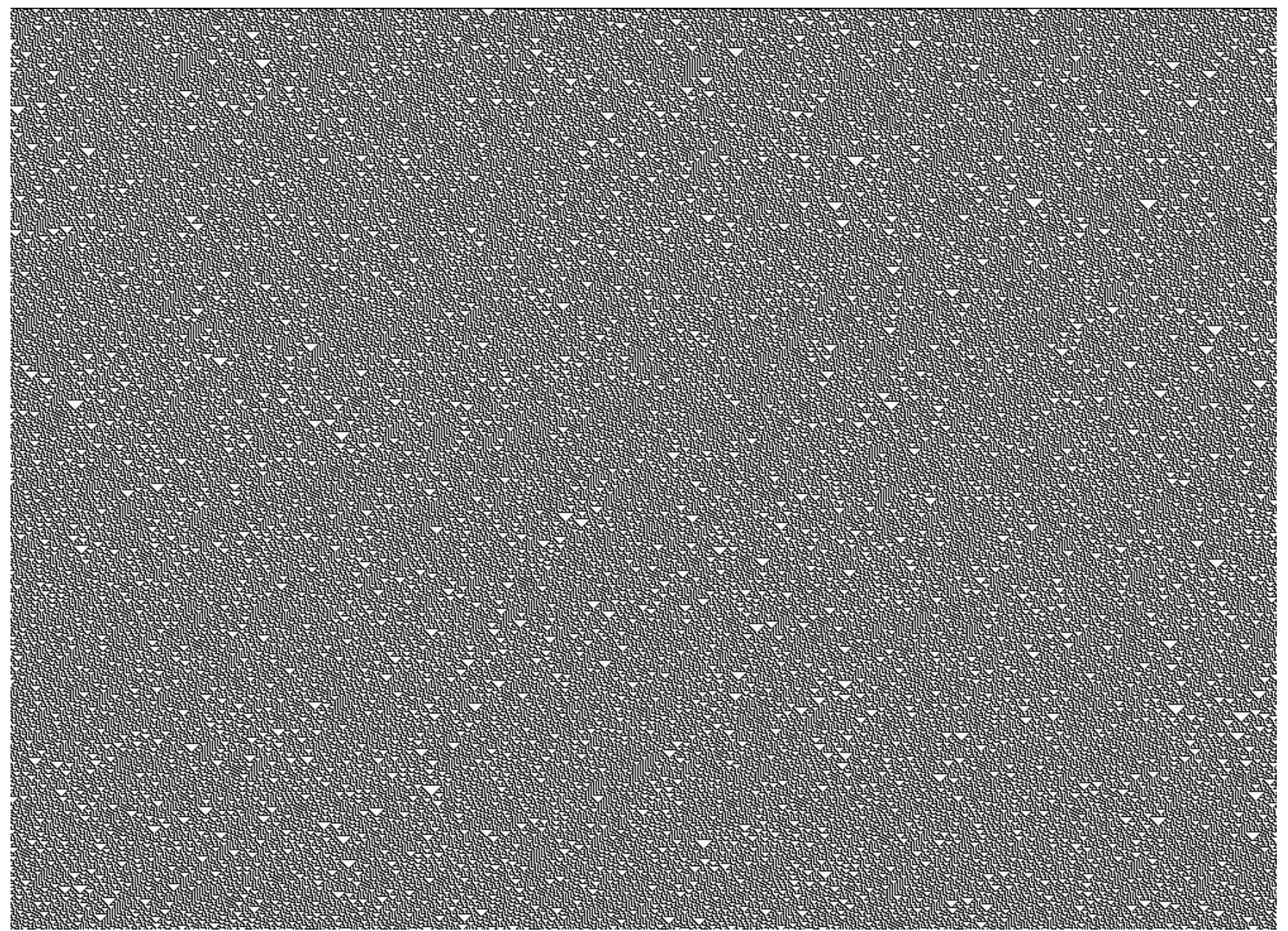

Figure 5. Function 3. Cellular automaton for 1000 educators in a 2-year730-day period, with corrupt educators being distributed randomly in day one 


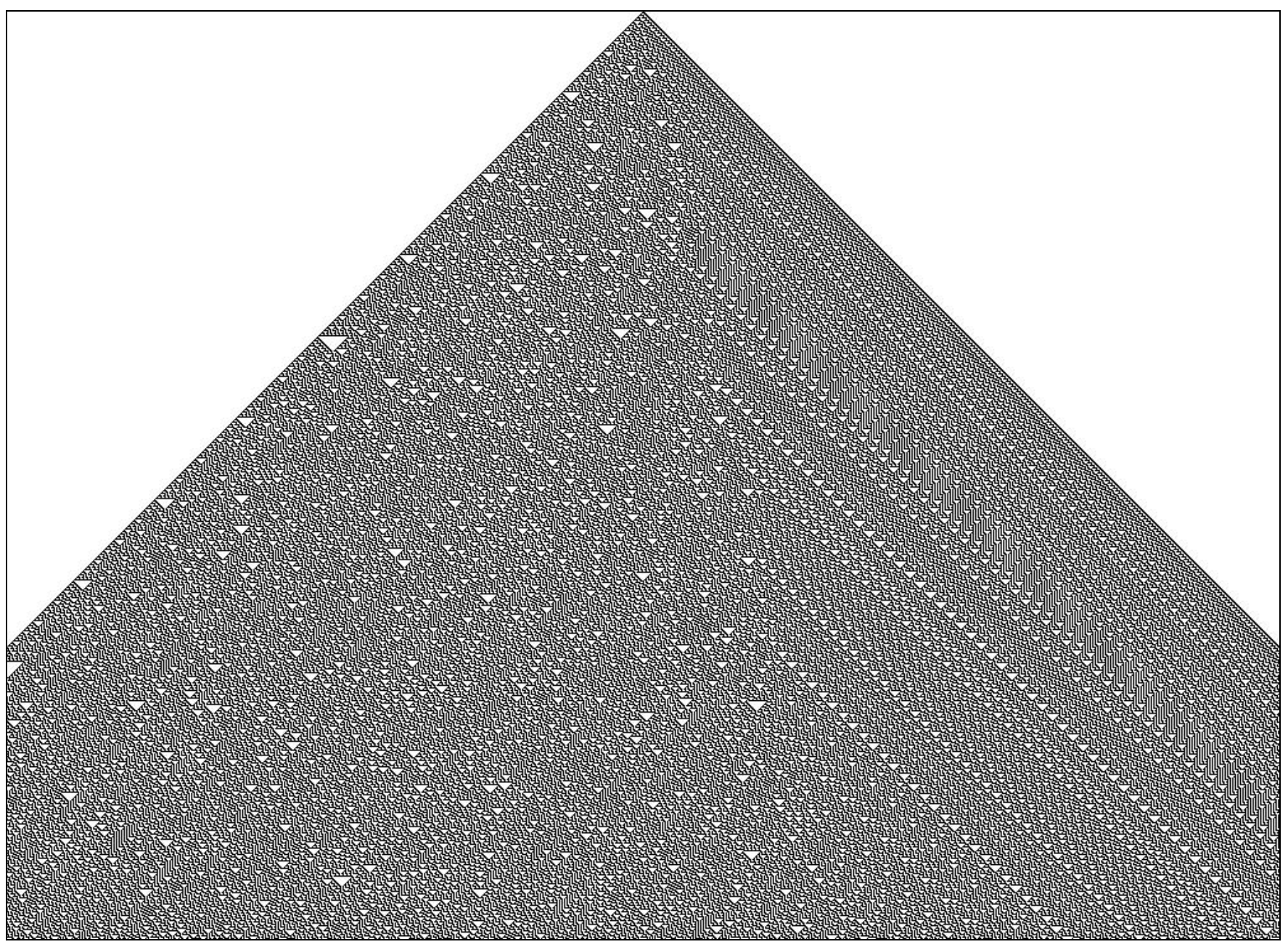

Figure 6. Function 3. Cellular automaton for 1000 educators in a 2-year730-day period, with one corrupt educator initially in day one 


\section{REFERENCES}

Alexeev, (1988). Market vs. Rationing: The case of Soviet Housing. The Review of Economics and Statistics, 70(3), pp. 414-420.

Almond, G., \& Coleman, J. (1960). The Politics of the Developing Areas. Princeton, NJ: Princeton University Press.

Anderson, M. (1992). Impostors in the Temple: American Intellectuals Are Destroying Our Universities and Cheating Our Students of Their Future. New York: Simon and Schuster.

Anderson, M. (1999). Uncovering the Covert: Research on Academic Misconduct. In J. Braxton (Ed.). Perspectives on Scholarly Misconduct in the Sciences. (pp. 283307). Columbus, OH: Ohio State University Press.

Anderson, M. (2001). The Complex Relations between the Academy and Industry: Views from the Literature. Journal of Higher Education, 72(2), pp. 226-246.

Anderson, M., \& Louis, K. (1989). Institutional Control of Faculty Research: Issues Emerging in the Academic Environment. Paper presented at the annual meeting of the Association for Study of Higher Education (ASHE).

Anderson, Martin. (1992). Impostors in the Temple: American Intellectuals Are Destroying Our Universities and Cheating Our Students of Their Future. New York: Simon and Schuster.

Anderson, Melissa. (1999). Uncovering the Covert: Research on Academic Misconduct. In John Braxton (Ed.). Perspectives on Scholarly Misconduct in the Sciences. Columbus, OH: Ohio State University Press. 
Anderson, Melissa. (2001). The Complex Relations between the Academy and Industry: Views from the Literature. Journal of Higher Education, 72(2), pp. 226-246.

Andreski, S. (1966). Parasitism and Subversion. London: Weidenfeld and Nicholson.

Andreski, S. (1968). Kleptocracy or Corruption as a System of Government. In S. Andreski (Ed.). The African Predicament: A Study in the Pathology of Modernization. New York: Atherton.

Anechiarico, F. \& Jacobs, J. (1995). The Pursuit of Absolute Integrity: How Corruption Control Makes Government Ineffective. Chicago, IL: University of Chicago Press.

Anechiarico, F., \& Jacobs, J. (1995). Panopticism and Financial Controls: The Anticorruption Project in Public Administration. Crime, Law and Social Change, 22, pp. 361-379.

Anechiarico, Frank, \& Jacobs, James. (1995). The Pursuit of Absolute Integrity: How Corruption Control Makes Government Ineffective. Chicago: University of Chicago Press.

Arora, David. (1993). Conceptualising the Context and Contextualising the Concept: Corruption Reconsidered. Indian Journal of Public Administration, 39, pp. 1-19. Arrowsmith, W. (1966). The Shame of the Graduate Schools. New York: Harper's. Azrael, J. (1965). Patterns of Polity-Directed Educational Development: Soviet Union. In J. Coleman (Ed.). Education and Political Development. Princeton, NJ: Princeton University Press.

Bac, M. (1996). Corruption, Supervision, and the Structure of Hierarchies. Journal of Law, Economics, and Organization, 12(2), pp. 277-298. 
Bac, M. (1998). Corruption and Supervision Costs in Hierarchies. Journal of Comparative Economics, 22(2), pp. 99-118.

Bac, M. (1998). The Scope, Timing, and Type of Corruption. International Review of Law and Economics, 18(1), pp. 101-120.

Bac, M. (2001). Corruption, Connections, and Transparency: Does a Better Screen Imply a Better Scene? Public Choice, 107(1-2), pp. 87-96.

Bailey, N., \& Richards, M. (1985). Tarnishing the Ivory Tower: Sexual Harassment in Graduate Training Programs in Psychology. In M. Paludi (Ed.). Ivory Power: Sexual Harassment on Campus. New York: State University of New York Press, 1990.

Baldwin J., \& Goldthwaite, R. (Eds.). (1972). Universities in Politics: Case Studies from the Late Middle Ages and Early Modern Period. Baltimore, MD: The John Hopkins University Press.

Banfield, E. (1975). Corruption as a Feature of Government Organization. Journal of Law and Economics, 18(3), pp. 587-605.

Bardhan, Pranab. (1997). Corruption and Development: a Review of Issues. Journal of Economic Literature, 35(3), pp. 1320-1346.

Bardhan, Pranab. (1997). Corruption and Development: A Review of Issues. Journal of Economic Literature, 35(3), pp. 1320-1346.

Basu K., Bhattacharya S., \& Mishra, A. (1992). Notes on Bribery and the Control of Corruption. Journal of Public Economics, 48, pp. 349-359.

Bates, R. (1981). Markets and States in Tropical Africa: the political basis of Agricultural Policies. Berkeley, CA: University of California Press. 
Becker, G., \& Stigler, G. (1974). Law Enforcement, Malfeasance, and the Compensation of Enforcers. Journal of Legal Studies, 3(1), pp. 1-18.

Bell, R. (1992). Impure Science: Fraud, Compromise, and Political Influence in Scientific Research. New York: Wiley.

Benson, G. (1978). Political Corruption in America. Lexington, MA: Lexington Books.

Berg, L., Hahn, H., \& Schmidhauser, J. (1976). Corruption in the American Political System. Morristown, NJ: General Learning Press.

Berry, F., \& Berry, W. (1999). Innovation and Diffusion Models in Policy Research. In Sabatier (Ed.). Theories of the Policy Process, (pp. 169-200). New York: Westview Press.

Bird, S., \& Dustira, A. (2000). New Common Federal Definition of Research Misconduct in the United States. Science and Engineering Ethics, 6(1), pp. 123-130.

Birnbaum, R. (1988). How Colleges Work: The Cybernetics of Academic Organization and Leadership. San Francisco, CA: Jossey Bass.

Biswal, B. (1999). Private Tutoring and Public Corruption: A Cost-effective Education System for Developing Countries. The Developing Economies, 37(2), pp. 222-240.

Blanchard, Ph., Krueger, A., Krueger, T., \& Martin, P. (2005). The epidemics of corruption. Physics and Society. May. Retrieved from http://arxiv.org/abs/physics/0505031

Blankenship, K., \& Whitley, B. (2000). Relation of General Deviance to Academic Dishonesty. Ethics and Behavior, 10, pp. 1-12.

Blasi, J. (1996). Kremlin Capitalism: The Privatization of the Russian Economy. Ithaca, NY: ILR Press. 
Bok, D. (1982). The Corporation on Campus: Balancing Responsibility and Innovation. Change, 14 (6), pp. 16-25.

Boljubash, Ya. (2006). Dopovidna zapiska pro stan roboti shodo vikorinennja, profilaktiki i zapobigannju projaviv habarnictva ta inshih negativnih javish u sferi osviti [The report on the situation with the complex of measures undertaken to eradicate, and prevent cases of bribery and other negative phenomena in the system of education]. Retrieved March 24, 2007 from http://www.mon.gov.ua/education/higher/rozv/2006/18_12_2.doc

Bolman, L., \& Deal, T. (1997). Reframing Organizations: Artistry, Choice, and Leadership. San Francisco, CA: Jossey Bass.

Bondarev, M. (2002). Nado botrot'sya s poddelkoy i verit' v rezul'tat [It is necessary to fight fraud and to believe in the results]. Uchitel'skaia Gazeta, September 24, 39, p. 11 .

BPC. (2007). Vysshee obrazovanie v Kyrgyzstane: Problemy i perspektivy [Higher Education in Kyrgyzstan: Problems and Perspectives]. Bishkek Press Club. February 19, 2007. Retrieved March 24, 2007 from http://www.bpc.kg/index.php?area=1\&p=news\&newsid=843

Braxton, J. (Ed.). (1999). Perspectives on Scholarly Misconduct in the Sciences. Columbus, OH: Ohio State University Press.

Bray, M. (2003). Adverse Effects of Private Supplementary Tutoring: Dimensions, Implications and Government Responses. Paris: International Institute for Educational Planning. 
Breitmayer, J. (2000). Responding to Allegations of Scientific Misconduct: The Procedure at the French National Medical and Health Research Institute. Science and Engineering Ethics, 6 (1), pp. 41-48.

Brockliss, L., Denley, P., \& Schmitt, C. (1981). History of Universities, Vol. I. London: Avebury.

Brydensholt, H. (2000). The Legal Basis for Danish Committee on Scientific Dishonesty. Science and Engineering Ethics, 6 (1), pp. 11-24.

Buchanan, J., Tollison, M., \& G. Tollock, G. (Eds.). (1980). Toward a Theory of the Rent-Seeking Society. College Station: Texas A\&M Press.

Cabelkova, I., \& Hanousek, J. (2004). The Power of Negative Thinking: Corruption, Perception and Willingness to Bribe in Ukraine. Applied Economics, 36(4), pp. 383-397.

Califano, J. (1970). The Student Revolution: A Global Confrontation. New York: W. W. Norton \& Company.

Callow, A. (1976). The City Boss in America. New York, NY: Oxford University Press.

Carillo, J. (2000). Corruption in Hierarchies. Annales D-economie Et De Statistique. Institut National De La Statistique Et Des Etudes Economiques, 59, pp. 37-61.

Carley, K., \& Gasser, L. (1999). Computational Organization Theory. In G. Weiss (Ed.). Distributed Artificial Intelligence. Cambridge, MA: MIT Press.

Carley, K., \& Prietula, M. (Eds.). (1994). Computational Organization Theory. Hillsdale, NJ: Lawrence Erlbaum Associates. 
Chapman, D. (2001). Higher Education in Post-Soviet Russia. In J. Muckle, and J. Morgan (Eds.). Post-School Education and the Transition from State Socialism. Nottingham: University of Nottingham Continuing Education Press.

Chapman, D. (2003). Selling (out) Education: Corruption and Quasi-Corruption in Higher Education in the Developing World. Paper presented at the annual meeting of the Association for Study of Higher Education, Portland, OR, November.

Charmaz, K. (2000). Grounded Theory: Objectivist and Constructivist Methods. In. N. Denzin \& Y. Lincoln (Eds.). Handbook of Qualitative Research (pp. 509-535). Thousand Oaks, CA: Sage.

Choi, J., \& Thum, M. (1998). The Economics of Repeated Extortion. Columbia University Working Paper \#9899-03.

Chubais, A. (2002). Interview on Corruption. Newsru.com, July 29.

Cichy, K. (1990). Ethical Implications of For-Profit Corporate Sponsorship of Research. Journal of the Society of Research Administrators, 22, pp. 23-27.

CityNews. (2006). Byvshy rector luganskogo filiala MAUP prisvoila 831,9 tysyach griven [Former president of the Lugansk branch of MAUP embezzled 831.9 thousand UAH]. December 25, 2006. Retrieved March 24, 2007 from http://www.citynews.net.ua/5/8925_1.html

Cizek, G. (1999). Cheating on Tests: How to do it, Detect it, and Prevent it. Mahwah, NJ: Lawrence Erlbaum Associates.

Coggins, P. (2000). Enhancing Efforts to Prevent Fraud in Higher Education. Community College Journal of Research and Practice, 24, pp. 657-666. 
Compayre, G. (1893). Abelard and the Origin and Early History of Universities. New York: Charles Scribner's Sons.

Creswell, J. (2002). Educational Research: Planning, Conducting, and Evaluating Quantitative and Qualitative Research. New Jersey: Merrill Prentice Hall.

Croucher, J. (1997). Exam Scams. London: Allen \& Unwin.

Culliton, B. (1987). Integrity of Research Papers Questioned. Science, January 23.

Darden, K. (2001). Blackmail as a Tool of State Domination. East European Constitutional Review, 10(2-3). Retrieved March 25, 2002, from http://www.law.nyu.edu/eecr/vol10num2_3/focus/darden.html

Darden, K. (2002). Graft and Governance: Corruption as an Informal Mechanism of State Control. New Haven, CT: Yale University Working Paper.

Decoo, W. (2002). Crisis on Campus: Confronting Academic Misconduct. Cambridge, MA: MIT Press.

Delany, J. (1997). Commercialism in Intercollegiate Athletics. Educational Record, 78, pp. 39-44.

Demidova, N. (2002). Sluzhilaja bjurokratija v Rossii XVII v. i ee rol' v formirovanii absoliutizma [Public Bureaucracy in Russia in $17^{\text {th }}$ Century and Its Role in Shaping Absolutism]. Moskva.

Demsetz, H. (1967). Towards a Theory of Property Rights. American Economic Review, 57(2), pp. 61-70.

Diekhoff, G. et al. (1996). College Cheating Ten Years Later. Research in Higher Education, 37(4), pp. 487-502. 
Downes, P., \& Levacic, R. (2004). Formula Funding Schools, Decentralization and Corruption: A Comparative Analysis. Paris: International Institute for Educational Planning.

Duderstadt, J. (2000). Intercollegiate Athletics and the American University. Ann Arbor, MI: The University of Michigan Press.

Dunn, (2003). Accountability, Democratic Theory, and Higher Education. Educational Policy, 17(1), pp. 60-79.

Easter, G. (2000). Reconstructuring the State: Personal Networks and Elite Identities in Soviet Russia. New York: Cambridge University Press.

Eckstein, M. (2003). Combating Academic Fraud. Towards a Culture of Integrity. Paris, International Institute on Educational Planning. IIEP Series on: "Ethics and Corruption in Education.” Retrieved April 12, 2004 from http://www.unesco.org/iiep http://unesdoc.unesco.org/images/0013/001330/133038e.pdf

Eckstein, M., \& Noah, H. (1993). Secondary School Examinations: International Perspectives on Policies and Practices. New Haven, CT: Yale University Press. Eckstein, Max. (2003). Combating Academic Fraud. Towards a Culture of Integrity. Paris: IIEP.

Eizenbaum, B. (2005). Novaya bol'shaya igra v Srednej azii [New Big Game in Central Asia]. Le Nouvel Observateur, April 18, 2005. Retrieved March 23, 2007 from http://iicas.org/2005/20_04_05_anv.htm

Ermann, M., \& Lundman, R. (Eds.). (1978). Corporate and Governmental Deviance. New York: Oxford University Press. 
Fairweather, J. (1996). Faculty Work and the Public Trust: Restoring the Value of Teaching and Public Service in American Academic Life. Boston: Allyn \& Bacon. Filippov, V. (2001). Vysshaya shkola Rossii pered vyzovami 21-go veka. [Russian higher education facing the challenges of the 21st century]. Vysshee Obrazovanie v Rossii, 1, pp. 5-15.

Flynn, J. (1988). Russia’s ‘University Question’: Origins to Great Reforms 1802-1863. In L. Brockliss (Ed.). History of Universities. Vol. VII. Oxford: Oxford University Press.

Friday, W., \& Hesburgh, T. (1993). Report of the Knight Foundation Commission on Intercollegiate Athletics. Miami, FL: Knight Foundation.

Giroux, H. (1995). Beyond the Ivory Tower: Public Intellectuals and the Crisis of Higher Education. In M. Berube and C. Nelson (Eds.), Higher Education under Fire: Politics, Economics, and the Crisis of the Humanities, (pp. 238-258). New York: Routledge.

Gladieux, L., Hauptman, A., \& Knapp, M. (1997). The Federal Government and Higher Education. In Goodchild, Lovell, Hines and Gill (Eds.). Public Policy and Higher Education, (pp. 103-124). Needham Heights, MA: Simon and Schuster.

Glaeser, E., La Porta, R., Lopez-de-Silanes, F., \& Schleifer, A. (2004). Do Institutions Cause Growth? Journal of Economic Growth, 9(3), pp. 271-303.

Glaser, B., \& Strauss, A. (1967). The Discovery of Grounded Theory. Chicago: Aldine Publishing Company.

Glebov, U. (2007). Centr korruptsii smestilsia v shkoly [Center of corruption shifted to secondary schools]. ExpressNovosti. February 16, 2007. Retrieved March 24, 
2007 from

http://www.expressnews.by/modules.php?name=news\&file=article\&sid=2181

Glenny, L., \& Dalglish, T. (1973). Public Universities, State Agencies, and Law.

Berkeley, CA: Center for Research and Development in Higher Education, University of California, Berkeley.

Goldsmith, H. (1998). The Impact of Technology on Academic Integrity. In D. Barnett, L. Rudolph, and K. Clifford (Eds.). Academic Integrity Matters. (pp. 135-141). Washington, D.C.: National Association of Student Personnel Administrators. Gong, T. (1997). Forms and characteristics of China's corruption in the 1990s: with continuity. Communist and Post-Communist Studies, 30(3), pp. 277-288.

Gong, T. (2002). Dangerous Collusion: Corruption as a Collective Venture in Contemporary China. Communist and Post-Communist Studies, 35(1), pp. 85-103.

Goodall, L. (1987). When Colleges Lobby States. Washington, DC: American Association of State Colleges and Universities.

Goorha, P. (2000). Corruption: Theory and Evidence Through Economies in Transition. International Journal of Social Economics, 27(12), pp. 21-36.

Gorodnichenko, Y., \& Sabirianova, K. (2006). Public Sector Pay and Corruption: Measuring Bribery from Micro Data. Paper submitted to the NEUDC annual conference, Ithaca, NY.

Gorshkov, S. (2005). Sadovnichiy: Pahan na zone? Retrieved March 22, 2007 from http://www.compromat.ru/main/sadovnichij/a.htm

Greaney, V., \& Kellaghan, T. (1996). The Integrity of Public Examinations in Developing Countries. In H. Goldstein and T. Lewis (Eds.). Assessment: 
Problems, Developments, and Statistical Issues. (pp. 167-188). New York: Wiley and Sons.

Greif, Avner, \& Laitin, David. (2004). A Theory of Endogenous Institutional Change. American Political Science Review, 98(4), (2004) 633-652.

Guliev, D. (2007). Esli obrazovanie v Azerbajdzhane ne vosstanovitsya, to eto mozhet privesti k raspadu gosudarstva [If education in Azerbaijan will not be rebuilt, it can lead to the state collapse]. Radio Azadlyg. February 18, 2007. Retrieved March 24, 2007 from http://aznocorruption.org/cgi-bin/e$\mathrm{cms} / \mathrm{vis} / \mathrm{vis} . \mathrm{pl}$ ? $\mathrm{s}=001 \& \mathrm{p}=0014 \& \mathrm{n}=000660 \& \mathrm{~g}=$

Guriev, S. (2003). Red Tape and Corruption. Journal of Development Economics, 73. Retrieved March 20, 2004, from http://www.transparency.org.ru/doc/NES\%20\%20Guriev\%20article\%20on\%20redtape_02700_1.pdf.

Hallak, J., \& Poisson, M. (2002). Ethics and Corruption in Education. Results from the Expert Workshop held at the IIEP. Paris, November 2001. Paris: IIEP-UNESCO. Hallak, J., \& Poisson, M. (2004). Challenges in Addressing Corruption in Education. Paris: IIEP-UNESCO. Presentation in Bishkek, November. Retrieved April 12, 2005 from http://www.spc.fsf.vu.lt/english/researches/bishkek_part1_eng.pdf

Hallak, Jacques, \& Poisson, Muriel. (2002). Ethics and Corruption in Education. Paris: IIEP.

Hallak, Jacques, \& Poisson, Muriel. (2007). Corrupt Schools, Corrupt Universities: What Can Be Done? Paris: IIEP.

Haskins, C. (1957). The Rise of The Universities. London: Cornell University Press. 
He, Z. (2000). Corruption and Anti-Corruption in Reform China. Communist and PostCommunist Studies, 33, pp. pp. 243-270.

Hellman, J. (2000). Measuring Governance, Corruption, and State Capture: How Firms and Bureaucrats Shape the Business Environment in Transition Economies. Washington, D.C.: World Bank.

Hellman, J., Jones, G., \& Kaufmann, D. (2000). Seize the State, Seize the Day: State Capture, Corruption, and Influence in Transition. World Bank Policy Research Working Paper 2444.

Heyneman, Stephen. (2002). Education and Corruption. Forum on Ethics in Business and Economics: Challenges for Higher Education. Almaty: Kazakhstan.

Heyneman, Stephen. (2004). Education and Corruption. International Journal of Educational Development, 24(3), pp. 637-648.

Heyneman, Stephen. (2007). Three Universities in Georgia, Kazakhstan and Kyrgyzstan: The struggle against corruption and for social cohesion. Prospects: Quarterly Review of Comparative Education, 37(3), pp. 305-318.

Heyneman, Stephen, Kathryn Anderson, and Nazym Nuraliyeva. (2008). The Cost of Corruption in Higher Education. Comparative Education Review, 52(1), pp. 1-26.

Hill, C. (1972). The Radical Critics of Oxford and Cambridge in the 1650s. In J. Baldwin and R. Goldthwaite (Eds.). Universities in Politics: Case Studies from the Late Middle Ages and Early Modern Period. Baltimore, MD: The Johns Hopkins Press. Hodgkinson, Peter. (1997). The Sociology of Corruption: Some Themes and Issues', Sociology, 31(1), pp. 17-35. 
Holmes, S. (1996). Cultural Legacies or State Collapse? Probing the Post-Communist Dilemma. In M. Mandelbaum (Ed.). Post-Communism: Four Perspectives. New York: Council of Foreign Relations.

Honorary Doctors 2000. University of Oslo. Retrieved May 12, 2004, from http://www.uio.no/english/about_uio/honorary-doctors/2000/

Hrebenar, R. (1997). Interest Group Politics in America. Armonk, NY: Sharpe.

Huntington, S. (1968). Political Order in Changing Societies. New Haven, CT: Yale University Press.

Hyde, J. (1972). Commune, University, and Society in Early Medieval Bologna. In J. Baldwin and R. Goldthwaite (Eds.). Universities in Politics: case Studies from the Late Middle Ages and Early Modern Period. Baltimore, MD: The Johns Hopkins Press.

Ivanov, V. Pravda I Lozh' bor'by s korruptsiey [Truth and Lies of the Fight with Corruption]. Vzgliad, November 10, 2005. Retrieved March 23, 2007 from http://www.vZ.ru/columns/2005/11/10/12214.html

Jarausch, K. (1974). The Sources of German Student Unrest 1815-1848. In L. Stone (Ed.). The_University in Society. Vol. II. Europe, Scotland, and the United States from the $16^{\text {th }}$ to the $20^{\text {th }}$ Century. Princeton, NJ: Princeton University Press.

Johns, R. (2003). Academic Corruption in Ukraine. Retrieved April 2, 2004 from http://www.fulbright.kiev.ua/newsletters/06/p04en.html

Johnston, M. (1982). Political Corruption and Public Policy in America. Belmont, CA: Brooks/Cole Publishing Co. 
Johnston, M. (1986). Right and Wrong in American Politics: Popular Concepts of Corruption. Polity, 18(3), pp. 367-391.

Johnston, M. (1989). Corruption and Political Culture in Britain and the United States. Innovation, 4, pp. 417-436.

Johnston, M. (1991). Right and Wrong in British Politics: "Fits of Morality" in Comparative Perspective. Polity, XXIV(1), pp. 1-25.

Johnston, Michael. (1996). The Search for Definitions: The Vitality of Politics and the Issue of Corruption, International Social Science Journal, 149, pp. 300-322.

Kagarlitsky, (2002). B. Political Capitalism and Corruption in Russia. Links, 21, pp. 8-20.

Kaminsky, H. (1972). The University of Prague in the Hussite Revolution: the Role of the Masters. In J. Baldwin and R. Goldthwaite (Eds.). Universities in Politics: Case Studies from the Late Middle Ages and Early Modern Period. Baltimore, MD: The Johns Hopkins Press.

Kaufmann, D. (1997). Corruption: The Facts. Foreign Policy, 107(2), pp. 11431.

Kaufmann, D. (1997). The Missing Pillar of a Growth Strategy for Ukraine: Institutional and Policy Reform for Private Sector Development. In P. Cornelius and P. Lenain, (Eds.). Ukraine: Accelerating the Transition to Market. (pp 234-275).

Washington, D.C: International Monetary Fund.

Kaufmann, D. (2001). Privatization, Corruption's Curse or Cure? Revisiting Some Notions and Evidence. Workshop Session, October, Tenth IACC, Prague, Czech Republic. 
Kaufmann, D., \& Wei, S. (1999). Does “Grease Money” Speed up the Wheels of Commerce? National Bureau of Economic Research Working Paper, no. 7093, Cambridge.

Kaufmann, Daniel, \& Vicente, Pedro. (2005). Legal Corruption, SSRN, p. 1-43. Retrieved December 29, 2007, from http://ssrn.com/abstract=829844

Kaye, Tim, Bickel, Robert, \& Birtwistle, Tim. (2006). Criticizing the image of the student as consumer: examining legal trends and administrative responses in the US and UK. Education and The Law, 18(2-3), pp. 85-129.

Keller, M. (1978). Corruption in America: Continuity and Change. In A. Eisenstadt, A. Hoogenboom, and H. Trefousse (Eds.), Before Watergate: Problems of Corruption in American Society. Brooklyn, NY: Brooklyn College Press.

Kerkvliet, J., \& Sigmund, C. (1999). Can We Control Cheating in the Classroom? Journal of Economic Education, 30(4), pp. 331-343.

Key, V. (1936). The Techniques of Political Graft in the United States. Chicago: The University of Chicago Libraries.

Khalil, F., \& Lawarree, J. (1993). Collusion in Hierarchical Agency. Econometrica, 61, pp. 629-656.

Khalil, F., \& Lawarree, J. (1995). Collusive Auditors. American Economic Review Papers and Proceedings, 85, pp. 442-447.

Khalil, F., \& Lawarree, J. (1996). On the Optimality of Allowing Collusion. Journal of Public Economics, 61, pp. 383-408.

Kibre, P. (1948). The Nations in The Mediaeval Universities. Cambridge, MA: Mediaeval Academy of America. 
Klitgaard, R. (1988) Controlling Corruption. Berkeley and Los Angeles: University of California Press.

Klitgaard, R. (1991). Gifts and Bribes. In R. Zeckhauser (Ed.). Strategy and Choice. Cambridge, MA: MIT Press.

Klitgaard, Robert. (1986). Elitism and Meritocracy in Developing Countries. Baltimore: John Hopkins University Press.

Kniazev, E. (2002). Coping with the New Challenges in Managing a Russian University. Higher Education Management and Policy, 14(1), pp. 109-126.

Kolesov, V. 2002. O vaucherizacii vysshego obrazovanija [About Voucherization of Higher Education]. Moscow: MGU. http://www.econ.msu.ru/dp.php3?id=254, accessed December 24, 2002.

Koshland, D. (1987). Fraud in Science. Science, January 9.

Kostikov, V. (2002). Anatomiya korruptsii II [The Anatomy of Corruption II]. Argumenty i Fakty, May 29, 22, p. 9. Retrieved March 24, 2007 from http://www.aif.ru/search?query=

Kotkin, S. (2001). Armageddon Averted: The Soviet Collapse 1970-2000. New York: Oxford University Press.

Kotkin, S., \& A. Sajo (Eds.). (2002). Political Corruption in Transition: A Skeptic's Handbook. Budapest: CEU Press.

Krueger, Anne. (1974). The Political Economy of a Rent-Seeking Society. American Economic Review, 64(3), pp. 291-302. 
Kunikova, J., \& Rose-Ackerman, S. (2001). Electoral Rules as Constraints on Corruption: The Risks of Closed-List Proportional Representation. Leitner Working Paper 2001-14.

Laffont, J., \& Martimort, D. (1997). Collusion under Asymmetric Information. Econometrica, 65, pp. 875-912.

Lambert-Mogiliansky, A. (1995). Indirect Monitoring and Optimal Collusion. Mimeo, Department of Economics, Stockholm University.

Lambsdorff, J. (1998). The Transparency International Corruption Perceptions Index: $7^{\text {th }}$ Edition. Retrieved May 1, 2003, from http://www.uni-goettingen.de/

Lasswell, H., \& Rogow, A. (1963). Corruption, Power, and Rectitude. Englewood Cliffs, NJ: Prentice Hall.

Lathrop, A., \& Foss, K. (2000). Student Cheating and Plagiarism in the Internet Era: a Wake-up Call. Libraries Unlimited, Inc.

Leach, J. (1999). The New Russian Menace. New York Times, September 10.

Lederman, D. (1997). Political Action Committees Help Lawmakers Who Help Colleges. The Chronicle of Higher Education, April 18.

Leff, N. (1964). Economic Development Through Bureaucratic Corruption. The American Behavior Scientist, 8(2), pp. 8-14.

Leon, P. (1993). Thinking about Political Corruption. Armonk, NY: M. E. Sharpe.

Lipset, S. (1960). Political Man: The Social Basis of Modern Politics. New York: Doubleday.

Lui, F. (1985). An Equilibrium Queuing Model of Bribery. Journal of Political Economy, 93(4), pp. 760-781. 
Lui, F. (1985). Essays on the Economics of Corruption. PhD Thesis, University of Minnesota.

Lui, F. (1986). A Dynamic Model of Corruption Deterrence. Journal of Public Economics, 31(2), pp. 215-236.

Lui, F. (1996). Three Aspects of Corruption. Contemporary Economic Policy, 14(3), pp. 26-29.

Lui, F. (1999). Bureaucratic Corruption and Endogenous Economic Growth. Journal of Political Economy, 107(6), pp. 270-293.

Magnus, J., Polterovich, V., Danilov, D., \& Savvateev, A. (2002). Tolerance of Cheating: An Analysis Across Countries. The Journal of Economic Education, 33(2).

Maieru, A. (1993). University Training in Medieval Europe. New York: Brill.

Maline, M., \& Maramark, S. (1993). Academic Dishonesty among College Students. Washington, D.C.: Office of Educational Research and Improvement.

Mallon, T. (1989). Stolen Words: Forays into the Origins and Ravages of Plagiarism. New York: Ticknor\&Fields.

Martimort, D. (1993). Multiprincipal Charter as a Safeguard against Opportunism in Organizations. Mimeo, INRA, Toulouse.

Matsuzato, K. (2001). From Communist Boss Politics to Post-Communist Caciquismo the Meso-Elite and Meso-Governments in Post-Communist Countries. Communist and Post-Communist Studies, 34(2), pp. 175-201.

Mauro, P. (1995). Corruption and Growth. The Quarterly Journal of Economics, 110(3), pp. 681-712.

Mauro, P. (1997) Why Worry About Corruption? Washington, D.C.: The World Bank. 
Mauro, P. (1997). The Effects of Corruption on Growth, Investment, and Government Expenditure: A Cross-Country Analysis. In K. Elliott (Ed.). Corruption and the Global Economy. Washington, D.C.: Institute for International Economics.

Mauro, P. (1997). Why Worry About Corruption? Washington, D.C.: The World Bank.

Mauro, P. (1998a). Corruption and the Composition of Government Expenditure. Journal of Public Economics, 69, pp. 263-279.

Mauro, P. (1998b). Corruption: Causes, Consequences, and Agenda for Further Research. Finance and Development. International Monetary Fund, March, pp. 11-14.

McCabe, D., \& Roth, N. (1995). Communication Strategies for Addressing Academic Dishonesty. Journal of College Student Development, 36, pp. 531-541.

McCabe, D., \& Trevino, L. (1996). What We Know About Cheating in College: Longitudinal Trends and Recent Developments. Change, 28(1), pp. 28-33.

McCabe, D., \& Trevino, L. (2001). Dishonesty in Academic Environments: The Influence of Peer Reporting Requirements. Journal of Higher Education, 72(1), pp. 29-45.

McCabe, D., Trevino, L., \& Butterfield, K. (1996). The Influence of Collegiate and Corporate Codes of Conduct on Ethics-Related Behavior in the Workplace. Business Ethics Quarterly, 6, pp. 461-476.

McCabe, D., Trevino, L., \& Butterfield, K. (1999). Academic Integrity in Honor Code and Non-Honor Code Environments. Journal of Higher Education, 70(2), pp. 211-234.

McChesney, F. (1997). Money for Nothing: Politicians, Rent Extraction, and Political Extortion. Cambridge, MA: Harvard University Press. 
McKinney's Consolidated Laws of New York Annotated with Practice Commentaries by William C. Donnito. Book 39. §170.00 to 219.end. West Group, 1999.

McKinney's Consolidated Laws of New York Annotated. Book 19. General Business Law. Thomson West. 2004.

McNair, B. (1991). Glasnost, Perestroika, and the Soviet Media. London: Routledge. Meeting at Moscow State Institute of International Relations. AzerTAg, Baku, 2004. Retrieved January 3, 2005, from http://www.ilhamaliyev.org/s07_meetings/_meeting_e.html?meeting_16_e.html

Miller, Seumas, Roberts, Peter, \& Spence, Edward. (2005). Corruption and AntiCorruption: An Applied Philosophical Approach. Upper Saddle River, NJ: Prentice Hall.

Miller, W., Grodeland, A. \& T. Y. Koshechkina, T. (2000). Victims or Accomplices? Extortion and Bribery in Eastern Europe. In A. Ledeneva, and M. Kurkchiyan (Eds.). Economic Crime in Russia. London: Kluwer Law International.

Milov, L. (2001). Velikorusskij pahar' i osobennosti rossijskogo istoricheskogo processa [The Great Russian Peasant and Specifics of Russian History]. Moskva.

Milovanovic, Michael. (2001). Endogenous Corruption in Emerging Industrial Relations, The Hungarian Academy of Sciences, 2001. Retrieved May 12, 2002, from www.policy.hu/milovanovic/corruption.html

Ministry of Education and Science of the Russian Federation, Osnovnye pokazateli deyatel'nosti uchrezhdenij vysshego professional'nogo obrazovaniya [Major Indicators of the Higher Education System], Retrieved March 23, 2007 from http://www.ed.gov.ru/uprav/stat/1846/ 
Ministry of Education and Science of Ukraine. Higher Education Institutions of Ukraine, database. Retrieved March 23, 2007 from http://www.education.gov.ua/pls/edu/educ.hei.eng

Mitchell, R. (1996). Political Bribery in Japan. Honolulu: University of Hawaii Press.

Miyazaki, I. (1981). China's Examination Hell: The Civic Service Examinations of Imperial China. New Haven, CT: Yale University Press.

Moffat, M. (1990). Undergraduate Cheating. ERIC document ED334921.

Moghaddam, A. (2006). Coding Issues in Grounded Theory. Issues in Educational Research, 16, pp. 1-12.

Moore, J. (Ed.). (1992). Congressional Ethics: History, Facts, and Controversy. Congressional Quarterly.

Murphy, K., Shleifer, A., \& Vishny, R. (1991). The Allocation of Talent: Implications for Growth. The Quarterly Journal of Economics, 105, pp. 503-530.

Murphy, K., Shleifer, A., \& Vishny, R. (1993). Why is Rent-Seeking so Costly to Growth? American Economic Review, 83(2), pp. 409-414.

Mustafaev, I. (2002). On the State of Higher Education in the Azerbaijan Republic, Report. Baku: Ministry of Education of Azerbaijan.

Myrdal, G. (1968). Asian Drama: An Enquiry into the Poverty of Nations. New York. Newsru.com. (2006). “Chistka” v riadah FSB, MVD, Prokuratury, tamozhni i Soveta Federatsii. [Cleaning" in FSB, MVD, Attorney General office, Customs office, and the Council of Federation/Upper House of the Parliament/]. Retrieved May 12 from http://www.newsru.com/russia/12may2006/chistka.html 
Newsru.com. (2007). Podpolkovnik militsii v Dagestane, otkryto zayavivshij o korruptsii v respublike, otstranen I prosit FSB o zashite. [Police colonel in Dagestan who openly spoke about corruption is dismissed and is seeking protection in FSB]. Retrieved February 21 from http://www.newsru.com/russia/21feb2007/bibulatov.html

No Longer Business as Usual: Fighting Bribery and Corruption. Paris: OECD Publications, CEDEX, 2002.

Noah, Harold, \& Eckstein, Max. (2001). Fraud and Education: the Worm in the Apple. Oxford: Rowman \& Littlefield.

Noonan, J. (1983). Bribery. In Encyclopedia of Crime and Justice. New York, NY: McMillan and Free Press.

Nye, Joseph. (1967). Corruption and Political Development: a Cost-Benefit Analysis. American Political Science Review, 61(2), pp. 417-427.

Oberemko, O. (2006). Platnoe vysshee obrazovanie: avansy institutsional'nyh izmenenij. [For-fee higher education: advancements of the institutional changes]. Mimeo. Moscow: State University Russian School of Economics. Retrieved March 9, 2007 from http://64.233.167.104/search?q=cache:2o7JoXAH9NYJ:isek.hse.ru/docs/obereme nko.doc+...

Olken, B. (2006). Corruption Perceptions vs. Corruption Reality. Paper presented at the annual conference of the NEUDC, Cornell University, Ithaca, NY.

Olsen, T., \& Torsvik, G. (1998). Collusion and Renegotiation in Hierarchies: A Case of Beneficial Corruption. International Economic Review, 39(2), pp. 413-439. 
Osborne, D. (1997) Corruption as Counter-Culture: Attitudes to Bribery in Local and Global Society. In B. Rider (Ed.). Corruption: The Enemy Within. (pp. 9-34). Hague: Kluwer Law International.

Osipian, Ararat. (2013a). Transforming University Governance in Ukraine: Collegiums, Bureaucracies, and Political Institutions. Higher Education Policy, forthcoming. Osipian, Ararat. (2013b). Will Bribery and Fraud Converge? Comparative Corruption in Higher Education in Russia and the USA. Compare: A Journal of Comparative Education, 43(1), pp. http://dx.doi.org/10.1080/03057925.2012.728374.

Osipian, Ararat. (2013c). Corrupt Organizations: Modeling Educators' Misconduct with Cellular Automata. Computational \& Mathematical Organization Theory, 19(1), pp. 1-24.

Osipian, Ararat. (2013d). Recruitment and Admissions: Combating Corruption and Fostering Transparency on the Path to Higher Education. In Transparency International: Global Corruption Report: Education. New York: Routledge. Forthcoming.

Osipian, Ararat. (2013e). Global and Local: Standardized Testing and Corruption in Admissions to Ukrainian Universities. In Carolyn A. Brown (Ed.). Globalisation, International Education Policy, and Local Policy Formation. New York: Springer. Forthcoming.

Osipian, Ararat. (2012a). Who is Guilty and What to Do? Popular Opinion and Public Discourse of Corruption in Russian Higher Education. Canadian and International Education Journal, 41(1), pp. 81-95. 
Osipian, Ararat. (2012b). Predatory Raiding in Russia: Institutions and Property Rights after the Crisis. Journal of Economic Issues, 46(2), pp. 469-479.

Osipian, Ararat. (2012c). Grey Areas in the Higher Education Sector: Legality versus Corruptibility. Brigham Young University Education and Law Journal, 1(1), pp. 140-190.

Osipian, Ararat. (2012d). Loyalty as Rent: Corruption and Politicization of Russian Universities. International Journal of Sociology and Social Policy, 32(3/4), pp. $153-167$.

Osipian, Ararat. (2012e). Education Corruption, Reform, and Growth: Case of PostSoviet Russia. Journal of Eurasian Studies, 3(1), pp. 20-29.

Osipian, Ararat. (2012f). Economics of Corruption in Doctoral Education: The Dissertations Market. Economics of Education Review, 31(1), pp. 76-83.

Osipian, Ararat. (2010a). Le Bourgeois Gentilhomme: Political Corruption of Russian Doctorates. Demokratizatsiya: The Journal of Post-Soviet Democratization, 18(3), pp. 260-280.

Osipian, Ararat. (2010b). Corruption in the Politicized University: Lessons for Ukraine's 2010 Presidential Elections. Innovation: The European Journal of Social Science Research, 23(2), pp. 101-114.

Osipian, Ararat. (2010c). Corrupt Organizational Hierarchies in the Former Soviet Bloc. Transition Studies Review, 17(4), pp. 822-836.

Osipian Ararat. (2010d). Korruptsiya v poslediplomnom obrazovanii [Corruption in doctoral education]. Terra Economicus, 8(3), pp. 48-63. 
Osipian, Ararat. (2009a). "Feed from the Service": Corruption and Coercion in the State-University Relations in Central Eurasia. Research in Comparative and International Education, 4(2), pp. 182-203.

Osipian, Ararat. (2009b). Vouchers, Tests, Loans, Privatization: Will They Help Tackle Corruption in Russian Higher Education? Prospects: Quarterly Review of Comparative Education, 39(1), pp. 47-67.

Osipian, Ararat. (2009c). Investigating Corruption in American Higher Education: The Methodology. FedUni Journal of Higher Education, 4(2), pp. 49-81.

Osipian, Ararat. (2009d). Corruption and Reform in Higher Education in Ukraine. Canadian and International Education Journal, 38(2), pp. 104-122.

Osipian, Ararat. (2009e). Corruption Hierarchies in Higher Education in the Former Soviet Bloc. International Journal of Educational Development, 29(3), pp. 321330.

Osipian, Ararat. (2009f). The Impact of Human Capital on Economic Growth: A Case Study in Post-Soviet Ukraine, 1989-2009. New York: Palgrave Macmillan

Osipian, Ararat. (2008a). Political Graft and Education Corruption in Ukraine: Compliance, Collusion, and Control. Demokratizatsiya: The Journal of PostSoviet Democratization, 16(4), pp. 323-344.

Osipian, Ararat. (2008b). Corruption in Higher Education: Does it Differ Across the Nations and Why? Research in Comparative and International Education, 3(4), pp. $345-365$.

Osipian, Ararat. (2008c). Corruption and Coercion: University Autonomy versus State Control. European Education: Issues and Studies, 40(3), pp. 27-48. 
Osipian, Ararat. (2007a). Corruption in Higher Education: Conceptual Approaches and Measurement Techniques. Research in Comparative and International Education, 2(4), pp. 313-332.

Osipian, Ararat. (2007b). Higher Education Corruption in Ukraine: Opinions and Estimates. International Higher Education, 49, pp. 20-21.

Osipian, Ararat. (2003a). Reforming Governance in Higher Education: Experience of the UK. European Dialog, 2, pp. 34-46.

Osipian, Ararat. (2003b). Reforming Governance in Higher Education: Experience of the UK. European Dialog, 1, pp. 36-51.

Ouchi, W., \& Segal, L. (2003). Making Schools Work: A Revolutionary Plan to Get Your Children the Education They Need. New York: Simon and Schuster.

Packard, H., \& Wolfram, S. (1985). Two-Dimensional Cellular Automata. Journal of Statistical Physics, 38(5-6), pp. 901-946.

Palmer, M. (1992a). Controlling Corruption. In P. Moir and H. Eijkman (Eds.). Policing Australia: Old Issues and New Perspectives. Melbourne, Australia: Macmillan.

Palmer, M. (1992b). What Makes Socialist Law Socialist? - The Chinese Case. In F. Feldbrugge (Ed.). The Emancipation of Soviet Law. Dordrecht and Boston.

Payne, P. (1975). The Corrupt Society: From Ancient Greece to Present-Day America. New York: Praeger Publishers.

Peters, J., \& Welch, S. (1978). Political Corruption in America: A Search for Definitions and a Theory, or If Political Corruption is in the Mainstream of American Politics, Why Is It not in a Mainstream of American Politics Research? American Political Science Review, 72(3), pp. 974-984. 
Petrov, Georgy, \& Temple, Paul. (2004). Corruption in Higher Education: Some Findings from the States of the Former Soviet Union. Higher Education Management and Policy, 16(1), pp. 82-94.

Philp, M. (1997). Defining Political Corruption. Political Studies, 45(3), pp. 436-462.

Piltz, A. (1981). The World of Medieval Learning. Basil: Blackwell.

Pisar'kova, L. (2004). Chinovnik na sluzhbe v kontse XVII - nachale XIX vv.

[Bureaucrat in the service in late $17^{\text {th }}$ - early $19^{\text {th }}$ century]. Otechestvennye zapiski, 2(17). Retrieved October 10, 2007, from http://www.stranaoz.ru/?numid=17\&article $=833$

Politics - Hospitals Trade Medical Care for Votes. Russia Journal Daily. March 16, 2004. Retrieved March 17, 2004, from www.russiajournal.com/news/cnewsarticle.shtml

Polterovich, A. (1998). Faktory Korruptsii [Factors of Corruption]. Ekonomikomatematicheskie metody, 34(3), pp. 22-34.

Popov, O. (2002). Korruptsiia v Rossii: Poniat' Znachit Pobedit'. [Corruption in Russia: To Understand is to Defeat]. Moscow: INDEM Foundation. Retrieved September 12, 2005, from www.indem.ru

Popov, O. (2005). Diagnosing Corruption in Russia: A Sociological Analysis. Russian Social Science Review, 46(1).

Pososhkov, I. (1937). Kniga o skudosti I bogatstve [The Book of Scarcity and Wealth]. Moskva.

Pulvers, K., \& Diekhoff, G. (1999). The Relationship Between Academic Dishonesty and College Classroom Environment. Research in Higher Education, 40, p. 487-498. 
Rait, Robert. (1931). Life in the Medieval University. Cambridge: Harvard University Press.

Rashdall, Hastings. (1936). The Universities of Europe in the Middle Ages: Salerno, Bologna, Paris. Vol. I. In B. Emden and M. Powicke (Eds.). The Universities of Europe in the Middle Ages. Oxford: Clarendon Press.

Rashdall, Hastings. (1936). The Universities of Europe in the Middle Ages: Italy, Spain, France, Germany, Scotland, etc. Vol. II. In B. Emden and M. Powicke (Eds.). The Universities of Europe in the Middle Ages. Oxford: Clarendon Press.

Rashdall, Hastings. (1936). The Universities of Europe in the Middle Ages: English Universities - Student Life. Vol. III. In B. Emden and M. Powicke (Eds.). The Universities of Europe in the Middle Ages. Oxford: Clarendon Press.

Rawls, J. (1993). Political Liberalism. New York: Columbia University Press.

RBC. Novosti obrazovanija: rossijskie vuzy gubit korruptsiya [Education News: Russian HEIs Suffer with Corruption]. September 20, 2003. Retrieved March 24, 2007 from http://www.curator.ru/news/news_180.html

Reinikka, R., \& Smith, N. (2004). Public Expenditure Tracking Surveys in Education: Peru, Uganda and Zambia. Paris: International Institute for Educational Planning.

Reinikka, R., \& Svensson, J. (2002). Measuring and Understanding Corruption at the Micro Level. In D. Della Porta and S. Rose-Ackerman (Eds.). Corrupt Exchanges: Empirical Themes in the Politics and the Political Economy of Corruption. Baden-Baden: Nomos Verlagsgesellschaft.

Reinikka, R., \& Svensson, J. (2004). Survey Techniques to Measure and Understand Corruption. World Development Report. 
Reinikka, R., \& Svensson, J. (2006) How Corruption Affects Service Delivery and What Can Be Done About It? In S. Rose-Ackerman, (Ed.). Handbook of Corruption. London: Edgar Elgar.

Reinikka, R., \& Svensson, J. (2006). Survey Techniques to Measure and Understand Corruption. World Development Report.

Rhoades, L., \& Gorski, A. (2000). Scientific Misconduct: an International Perspective. Science and Engineering Ethics, 6(1), pp. 5-10.

RIA Novosti. (2004). Minobrazovaniya priznaet nalichie korruptsii v sisteme obrazovaniya [Ministry of Education admits presence of corruption in the system of education]. RIA Novosti, February 22, 2004. Retrieved March 24, 2007 from http://www.zarplata.ru/n-id-4109.html

Roig, M. (1999). When College Students' attempts at Paraphrasing Become Instances of Potential Plagiarism. Psychological Reports, 84, pp. 973-982.

Rose-Ackerman, S. (1974). The Economics of Corruption. Philadelphia, PA: Pennsylvania University, Fels Discussion Paper \#53.

Rose-Ackerman, S. (1999). Corruption and Government: Causes, Consequences, and Reform. New York: Cambridge University Press.

Rose-Ackerman, Susan. (1978). Corruption: A Study in Political Economy. New York: Academic Press.

Rudenko, S. (2002). Lipy ne budet. Na strazhe - politsiya kachestva [There will be no fraud - the "quality police" is on guard]. Uchitel' skaia Gazeta, December, 52. Retrieved March 23, 2007 from www.ug.ru. 
Sabot, R., \& Wakeman-Linn, J. (1991). Grade Inflation and Course Choice. Journal of Economic Perspectives. 5(1), pp. 160-162.

Sadovnichiy, V. (2001). O reforme i korrupcii v vysshem obrazovanii [About the Reform and Corruption in Higher Education]. NTV, 2001. Retrieved October 3, 2001, from www.ntvru.com/russia/03Oct2001/sadovnichiy_bribe.html

Sajo, A. (1998). Corruption, Clientelism, and the Future of the Constitutional State in Eastern Europe. East European Constitutional Review, 7(2). Retrieved May 20, 2002, from http://www.law.nyu.edu/eecr/vol7num2/special/special.html

Sajo, A. (2003). From Corruption to Extortion: Conceptualization of Post-Communist Corruption. Crime, Law and Social Change, 40(2-3), pp. 171-194.

Saleh, (2003). On Corruption in the USSR. Retrieved March 23, 2007 from http://www.uzbekistanerk.org/books21/BERIKAN_5ru.htm\#_ftnref1)

Samik-Ibrahim, R. (2000). Grounded Theory Methodology as the Research Strategy for a Developing Country. Forum: Qualitative Social Research, 1(1).

Sandgren, A. (2002). Entrepreneurialism in Russian Universities. SRHE International News, 50, pp. 10-12.

Saxe, L., \& Spalter, A. (1992). Everybody (Else) Does It: Academic Cheating. ERIC document ED347931.

Sayed, T., \& Bruce, D. (1998). Inside and Outside the Boundaries of Police Corruption. African Security Review, 7(2). Retrieved May 20, 2002, from http://www.iss.co.za/Pubs/ASR/7No2/SayedAndBruce.html

Sayed, Taleh, \& Bruce, David. (1998). Police Corruption: Towards a Working Definition, African Security Review, 7(1), pp. 1. Retrieved May 20, 2002, from 
http://www.iss.co.za/ASR/7No1/SayedBruce.html

Scott, J. (1969). Corruption, Machine Politics, and Political Change. American Political Science Review, 63, pp. 1142-1158.

Scott, J. (1972). Comparative Political Corruption. Englewood Cliffs, NJ: Prentice-Hall. Segal, Lydia. (2004). Battling Corruption in America's Public Schools. Boston: Northeastern University Press.

Sergeev, I. (2002). Mikser dlia kuharkinyh detey [A mixer for kitchen-servant's children], Moskovskii Komsomolets, January 10, 5, p. 4. Retrieved March 24, 2007 from http://www.mk.ru/newshop/search.asp

Shao, J., Ivanov, P., Podobnik, B., \& Stanley, E. (2007). Quantitative relations between corruption and economic factors. The European Physical Journal B - Condensed Matter and Complex Systems, 56(2), pp. 157-166.

Shlapentokh, V. (2003). Russia's Acquiescence to Corruption Makes the State Machine Inept. Communist and Post-Communist Studies, 36, pp. 151-161.

Shleifer, A., \& Treisman, D. (2003). A Normal Country. NBER Working Paper 10057. Retrieved January 4, 2004 from www.nber.org/papers/w10057

Shleifer, Andrei, \& Vishny, Robert. (1993). Corruption. Quarterly Journal of Economics, 108(3), pp. 599-617.

Silber, J. (1970). The Integrity and Credibility of Higher Education on the Part of Students, Faculty, and Administrators. Washington, D.C.: American Association for Higher Education.

Silber, J. (1980). Marketing Higher Education: The Survival Value of Integrity. Journal of the National Association of College Admissions Counselors, 24(3), pp. 6-9. 
Simon, O. (1971). Confessions of an American Scholar. Minneapolis: University of Minnesota Press.

Smolentseva, A. (2000). Bridging the Gap Between Higher and Secondary Education in Russia. International Higher Education, 19, pp. 20-21.

Smolentseva, A. (2002). Reforming Admissions in Russian Higher Education. International Higher Education, 29, pp. 17-18.

Snyder, P. (1974). A Classification of Diploma Mills in the United States. College Student Journal.

Soley, L. (1995). Leasing the Ivory Tower: The Corporate Takeover of Academia. Boston: South End Press.

Solnick, S. (1998). Stealing The State: Control and Collapse in Soviet Institutions. Cambridge, MA: Harvard University Press.

Solomon, P., \& Foglesong, T. (2001). The Two Faces of Crime in Post-Soviet Ukraine. East European Constitutional Review, 3, pp. 72-76.

Solov'ev, S. (1991). Sochinenija. Kn. VII. [Collection of works, Vol. VII]. Moskva.

Some Regions Spoil President's Election Party. Russia Journal Daily, March 16, 2004. Retrieved March 17, 2004, from www.russiajournal.com/news/cnewsarticle.shtml

Soto, H. de. (1989). The Other Path: the Invisible Revolution in the Third World. New York: Harper \& Row.

Sperber, M. (1990). College Sports, Inc. New York: Henry Holt. Sperber, M. (2000). Beer and Circus: How Big-Time College Sports is Crippling Undergraduate Education. New York: Henry Holt. 
Spiridonov, V. (2000). Attitudes to Bribery and Blat in Contemporary Russian Society: The Psychologist's View. In S. Lovell, A. Ledeneva, and A. Rogachevskii (Eds.). Bribery and Blat in Russia. London: Macmillan.

Staff Comments of the Commission on revision of the Penal Law. Revised Penal law. McKinney’s Spec. Pamph, (1965).

Stegemann-Boehl, S. (2000). Misconduct in Science and The German Law. Science and Engineering Ethics, 6(1), pp. 57-62.

Stetar, J., Panych, O., \& Cheng, B. (2005). Confronting Corruption: Ukrainian Private Higher Education. International Higher Education, 38, pp. 13-15.

Stewart, D. (1988). Diploma Mills. New York: American Council on Education.

Stewart, W., \& Feder, N. (1987). We Must Deal Realistically with Fraud and Error. The Scientist, December 14.

Strauss, A., \& Corbin, J. (1998). Basics of Qualitative Research: Techniques and Procedures for Developing Grounded Theory. Thousand Oaks, CA: Sage.

Strausz, R. (1996). Collusion and Renegotiation in a Principal-Supervisor-Agent Relationship. Mimeo, Free University of Berlin.

Suroor, H. (2005). Cash for Class at Oxbridge. Viewpoint, 443(23).

Svensson, J. (2003). Who Must Pay Bribes and How Much? Evidence from a Cross Section of Firms. The Quarterly Journal of Economics, 118(1), pp. 207-30.

Svensson, J. (2005). Eight Questions about Corruption. Journal of Economic Perspectives, 19(3), pp. 19-42. 
Swazey, J., Louis, K., \& Anderson, M. (1989). University Policies and Ethical Issues in Research and Graduate Education: Highlights of the CGS Deans' Survey. CGS Communicator, 13(3), p. 2.

Sykes, Carol. (1988). ProfScam: Professors and The Demise of Higher Education.

Washington, D.C.: Regnery Gateway.

Tanzi, V. (1998). Corruption Around the World: Causes, Consequences, Scope and Cures. IMF Staff Papers 45(4).

Tasker, M., \& Packham, D. (1994). Government, Higher Education, and the Industrial Ethic. Higher Education Quarterly, 48(3).

The Development Strategy of the Russian Federation until 2010. (2000). Moscow:

Government of the Russian Federation.

Thelin, John. (1982). Higher Education and Its Useful Past. Cambridge, MA: Schenkman Publishing Company.

Tirole, J. (1986). Hierarchies and Bureaucracies: on the Role of Collusions in Organizations. Journal of Law, Economics and Organization, 2(2), pp. 181-214.

Tirole, J. (1992). Collusion and the Theory of Organizations. In J. Laffont (Ed.). Advances in Economic Theory, Sixth World Congress Vol. II. (pp. 151-206). Cambridge: Cambridge University Press.

Tirole, J. (1996). A Theory of Collective Reputations: with Applications to the Persistence of Corruption and to Firm Quality. Review of Economic Studies, 63(1), pp. 1-22. 
Tirole, Jean. (1992). Collusion and the Theory of Organizations. In J. Laffont (Ed.). Advances in Economic Theory. Sixth World Congress, Vol. 2. Cambridge: Cambridge University Press.

Transparency International (2012). Corruption Perceptions Index. Retrieved January 22, 2013, from http://www.transparency.org/cpi2012/results

Transparency International (2006). Corruption Perceptions Index. Retrieved June 22, 2007, from http://www.transparency.org/policy_research/surveys_indices/cpi Transparency International (2006). Global Corruption Barometer. Retrieved June 22, 2007, from http://www.transparency.org/policy_research/surveys_indices/gcb/2006

Treisman, D. (1999). Decentralization and Corruption: Why Are Federal States Perceived to Be More Corrupt? Presented at the Annual Meeting of the American Political Science Association, September, Atlanta.

Treisman, D. (2000). The Causes of Corruption: A Cross-National Study. Journal of Public Economics, 76, pp. 399-457.

Tudoryanu, G. (2007). Korrupcija v sisteme vysshego obrazovanija predstavljaet soboj ugrozu moral'nym cennostjam molodezhi [Corruption in the system of Higher Education is a threat to the moral values of the youth]. March 15, 2007. Retrieved March 24, 2007 from http://www.newsmoldova.ru/print_version.html?nws_id=610152

Tumennasan, B. (2005). Fiscal Decentralization and Corruption in Public Sector. Georgia State University, Doctoral Thesis, 129 p.

United Nations. (2003). Human Development Report 2002. New York: United Nations. 
United States Code Service: Lawyers Edition. Crimes and Criminal Procedures $§ § 1-430$.

Title 18 USCS.

United States Code Service: Lawyers Edition. General Index A-C, USCS.

Varian, H. (1990). Monitoring Agents with other Agents. Journal of Institutional and Theoretical Economics, 146, pp. 153-174.

Verger, J. (1972). The University of Paris at the End of the Hundred Years' War. In J. Baldwin and R. Goldthwaite (Eds.). Universities in Politics: case Studies from the Late Middle Ages and Early Modern Period. Baltimore, MD: The Johns Hopkins Press.

Verger, J. (2000). The First French Universities and the Institutionalization of Learning: Faculties, Curricula, Degrees. In J. Engen (Ed.). Learning Institutionalized: Teaching in the Medieval University. Notre Dame, IN: University of Notre Dame Press.

Volkwein, A. (1987). State Regulation and Campus Autonomy. In J. Smart (Ed.). Higher Education: Handbook of Theory and Research, (pp. 120-154). Vol. III, New York: Agathon.

Wade, R. (1982). The System of Administrative and Political Corruption: Canal Irrigation in South India. Journal of Development Studies, 18(3), pp. 287-328.

Waite, Duncan, \& Allen, David. (2003). Corruption and Abuse of Power in Educational Administration. The Urban Review, 35(4), pp. 281-296.

Washburn, Jennifer. (2005). The Corporate Corruption of American Higher Education. New York: Basic Books. 
Waterbury, J. (1973). Endemic and Planned Corruption in a Monarchical Regime. World Politics, 25.

Weber, M. (1952). The Essentials of Bureaucratic Organization: An Ideal-Type Construction. In R. Merton et al. (Eds.). Reader in Bureaucracy. New York, NY: Free Press.

Weber, Max. (1978). Economy and Society. Berkeley, CA: University of California Press. White, George. (1996a). Corruption and the Transition from Socialism in China. Journal of Law and Society, 23(1), pp. 149-169.

White, George. (1996b). Corruption and the Transition from Socialism in China. In M. Levi and D. Nelken (Eds.). The Corruption of Politics and the Politics of Corruption. Oxford: Blackwell.

Wilshire, B. (1990). The Moral Collapse of The University: Professionalism, Purity, and Alienation. New York: State University of New York Press.

Wilson, (1975). The Rise of the Bureaucratic State. In S. Theodoglu and M. Cahn (Eds.). Public Policy (pp. 251-258). New York.

Wilson, James. (1975). The Rise of the Bureaucratic State. In Theodoulou and Cahn (Eds.). Public Policy, (pp. 251-258). Boston: Kluwer.

Wirl, F. (1998). Socio-Economic Typologies of Bureaucratic Corruption and Their Implications. Journal of Evolution Economics, 8(2), pp. 199-220.

Wolfram, S. (1984). Universality and Complexity in Cellular Automata. Physica D: Nonlinear Phenomena, 10(1-2), pp. 1-35.

Wolfram, S. (1986). Random Sequence Generation by Cellular Automata. Advances in Applied Mathematics, 7(2), pp. 123-169. 
Wolfram, S. (1994). Cellular Automata and Complexity: Collected Papers. New York: Springer.

Woronowycz, R. (2003). Nationwide Survey Reveals Culture of Corruption in Ukraine. Ukrainian Weekly, vol. LXXI, 4 (January 26). Retrieved May 20, 2004, from http://www.ukrweekly.com/Archive/2003/040302.shtml

Yerevan.ru. (2006). Bagrat Esayan razobralsya s korruptsiey, teper' zajmetsia obraozovaniem [Bagrat Esayan eradicated corruption and is now moving to education]. Yerevan.ru. May 19, 2006. Retrieved March 24, 2007 from http://www.yerevan.ru/news/?task=detailed\&id=4195

Zhdanov, I. (2002). Corruption in Ukraine: Essence, Scale, and Influence. Connections, 1(2). Retrieved 20 May 2004, from http://www.ciaonet.org/olj/co/co_apr02d.pdf 